Founder: Federal Scientific Center for Medical and Preventive Health Risk Management Technologies Federal Service for Surveillance on Consumer Rights Protection and Human Wellbeing

\section{Contact Information:}

82 Monastyrskaya St., Perm, 614045, Russia Tel/Fax: +7 (342) 237-25-34

E-mail: journal@fcrisk.ru

Site: journal.fcrisk.ru/eng

Editor and corrector - M.N. Afanaseva

Technical Editor - M.M. Tsunker Translators - N.V. Dubrovskaya, N.A. Tregubova

All rights reserved. No part of this publication may be stored in the computer's memory or reproduced in any way without the prior written permission of the publisher.

The publication 30.06.2017.

Format $90 \times 60 / 8$.

Order No.1140/2017.

Edition is 500 copies.

The price is free.

The Journal is registered by The Federal Service For Supervision Of Communications, Information Technology, And Mass Media (Roscomnadzor). Register certificate СМИ - ПИ No. ФС 77-52552 issued on January 21, 2013

Address of the publisher and printing house: 29 Komsomolsky ave., Perm, 614990, Russia, tel.: +7 (342) 219-80-33

Printed by the Publishing House of Perm National Research Polytechnic University (29 Komsomolsky ave., Perm, 614990, Russia, tel.: +7 (342) 219-80-33)

\section{Subscription number:catalog \\ "Russian Post" \\ ("Interregional subscription agency") 04153}

ISSN (Print) 2308-1155

ISSN (Online) 2308-1163

ISSN (Eng-online) 2542-2308

\section{HEALTH RISK ANALYSIS}

Theoretical and practical journal. Start of publication: 2013 4 issues per year

\section{EDITORIAL BOARD}

G.G. Onishchenko - Editor in Chief, Fellow of the Russian Academy of Sciences, DSc, Professor (Moscow, Russia)

N.V. Zaitseva - Deputy Chief Editor, Fellow of the Russian Academy of Sciences, DSc, Professor (Perm, Russia) I.V. May - Executive Secretary, DSc, Professor (Perm, Russia)

\section{EDITORS}

S.L. Avaliani - DSc, Professor (Moscow, Russia)

A.B. Bakirov - DSc, Professor (Ufa, Russia)

E.N. Belyaev - corresponding member of RAS, DSc, Professor (Moscow, Russia)

V.M. Boev - DSc, Professor, (Orenburg, Russia)

I.V. Bragina-DSc (Moscow, Russia)

R.V. Buzinov - DSc (Arkhangelsk, Russia)

I.V. Bukhtiyarov - corresponding member of RAS, DSc,

Professor (Moscow, Russia)

V.B. Gurvich - DSc (Ekaterinburg, Russia)

I. Dardynskaia - DSc, Professor (Chicago, USA)

MA. Zemlyanova - DSc (Perm, Russia)

U.I. Kenesariev - DSc, Professor, corresponding member of the Academy of Medical Sciences of Kazakstan

(Almaty, Kazakstan)

T. Cronberg - DSc in Ec., DSc in Tec., Member of the European Parliament from Finland. (Ruveslahti, Finland)

S.V. Kuz'min - DSc, Professor (Ekaterinburg, Russia)

V.V. Kutyrev - Fellow of the Russian Academy of Sciences, DSc, Professor (Saratov, Russia)

V.R. Kuchma - corresponding member of RAS, DSc,

Professor, (Moscow, Russia)

A.V. Mel'tser - DSc, Professor (St.-Petersburg, Russia)

A.Ya. Perevalov - DSc, Professor (Perm, Russia)

Y.P. Pivovarov - Fellow of RAS, DSc, Professor

(Moscow, Russia)

A.Yu. Popova - DSc, Professor (Moscow, Russia)

V.N. Rakitskiy - Fellow of RAS, DSc, Professor, (Moscow, Russia)

S.I. Savelyev - DSc, Professor (Lipetsk, Russia)

P. Spencer - PhD, FRCPath Professor Department of neurology (Portland, USA)

V.F. Spirin - DSc, Professor (Saratov, Russia) Director A.Tsakalof - Professor of Medical Chemistry (Larissa, Greece)

V.A. Tutelyan - Fellow ofRAS, DSc, Professor (Moscow, Russia)

H.H. Hamidulina - DSc, professor, (Moscow, Russia)

V.A. Horoshavin - DSc, professor, (Perm, Russia)

S.A. Hotimchenko - DSc, professor (Moscow, Russia)

L.M. Shevchuk - PhD (Minsk, Belarus)

N.V. Shestopalov -DSc, Professor (Moscow, Russia)

P.Z. Shur - DSc, professor (Perm, Russia)

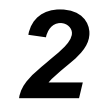

\section{April 2017 June}




\section{PREVENTIVE MEDICINE. URGENT ASPECTS OF RISK ANALYSIS}

N.V. Zaitseva, I.V. May, D.A. Kiryanov SCIENTIFIC-METHODOLOGICAL APPROACHES TO DESIGNING RISK-ORIENTED MODEL OF CONTROL AND SURVEILLANCE ACTIVITIES IN THE SPHERE OF CONSUMER RIGHTS PROTECTION

V.A. Kaptsov, V.N. Deinego HEALTH RISKS OCCURRING WHEN COLOR IS PERCEPTED UNDER LED LIGHTING

SCIENTIFIC AND METHODOLOGICAL APPROACHES TO RISK ANALYSIS IN HYGIENE AND EPIDEMIOLOGY

I.V. May, N.V. Nikiforova, V.A. Khoroshavin METHODOLOGICAL APPROACHES AND PRACTICES FOR ASSESSING CONSUMERS' HEALTH RISKS CAUSED BY DURABLE GOODS (ON THE EXAMPLE OF CONSTRUCTION AND FINISHING MATERIALS)

S.P. Levashov ANALYZING AND DEVELOPING CRITERIA FOR ASSESSING OCCUPATIONAL TRAUMATISM RISKS BASING ON «BEST PRACTICE CODE»

\section{RISK ASSESSMENT PRACTICE} IN HYGIENIC AND EPIDEMIOLOGICAL STUDIES

K.P. Luzhetskiy METHODICAL APPROACHES TO MANAGING RISKS FOR ENDOCRINE DISEASES EVOLVEMENT IN CHILDREN RELATED TO IMPACTS OF ENVIRONMENTAL FACTORS OCCURING ON AREAS AIMED FOR DEVELOPMENT

V.M. Boev, D.A. Kryazhev, L.M. Tulina, A.A. Neplokhov ASSESSMENT OF CARCINOGENIC

HEALTH RISK FOR POPULATION LIVING IN MONOCITIES AND RURAL SETTELEMENTS

V.V. Suchkov, S.A. Khotimchenko, O.V. Sazonova, D.O. Gorbachev, T.K. Ryazanova, E.A. Semaeva POPULATION HEALTH RISK RELATED TO INCREASED CONTENT OF BENZPYRENE IN SOIL

S.V. Kleyn, S.Yu. Balashov, E.G. Stepanov, N.Kh. Davletnurov TRIAL HYGIENIC ASSESSMENT AND MINIMIZING ENVIRONMENTAL HEALTH RISKS DURING LEADERS COUNCIL MEETING OF SHANGHAI COOPERATION ORGANIZATION COUNTRIES AND MEETING OF LEADERS AND GOVERNMENT HEADS OF BRICS COUNTRIES HELD IN UFA
ПРОФИЛАКТИЧЕСКАЯ МЕДИЦИНА. АКТУАЛЬНЫЕ АСПЕКТЫ АНАЛИЗА РИСКА ЗДОРОВЬЮ

4 Н.В. Зайцева, И.В. Май, Д.А. Кирьянов НАУЧНО-МЕТОДИЧЕСКИЕ ПОДХОДЫ К ФОРМИРОВАНИЮ РИСК-ОРИЕНТИРОВАННОЙ МОДЕЛИ КОНТРОЛЬНО-НАДЗОРНОЙ ДЕЯТЕЛЬНОСТИ В СФЕРЕ ЗАЩИТЫ ПРАВ ПОТРЕБИТЕЛЕЙ

16 В.А. Капичов, В.Н. Дейнего ВОСПРИЯТИЕ ЦВЕТА ПРИ СВЕТОДИОДНОМ ОСВЕЩЕНИИ - РИСКИ ЗДОРОВЬЮ

\section{НАУЧНО-МЕТОДИЧЕСКИЕ ПОДХОДЫ К АНАЛИЗУ РИСКА В ГИГИЕНЕ И ЭПИДЕМИОЛОГИИ}

25 И.В. Май, Н.В. Никифорова, В.А. Хорошавин МЕТОДИЧЕСКИЕ ПОДХОДЫ К ОЦЕНКЕ РИСКА ДЛЯ ЗДОРОВЬЯ ПОТРЕБИТЕЛЕЙ ПРОДУКЦИИ ДЛИТЕЛЬНОГО ПОЛЬЗОВАНИЯ (НА ПРИМЕРЕ СТРОИТЕЛЬНЫХ МАТЕРИАЛОВ)

35 С.П. Левашов АНАЛИЗ И РАЗРАБОТКА КРИТЕРИЕВ ОЦЕНКИ И ОЦЕНИВАНИЯ РИСКОВ ПРОФЕССИОНАЛЬНОГО ТРАВМАТИЗМА НА ОСНОВЕ «КОДЕКСА ЛУЧШЕЙ ПРАКТКИ»

ПРАКТИКА ОЦЕНКИ РИСКА В ГИГИЕНИЧЕСКИХ И ЭПИДЕМИОЛОГИЧЕСКИХ ИССЛЕДОВАНИЯХ

45 К.П. Лужеикий МЕТОДИЧЕСКИЕ ПОДХОДЫ К УПРАВЛЕНИЮ РИСКОМ РАЗВИТИЯ У ДЕТЕЙ ЭНДОКРИННЫХ ЗАБОЛЕВАНИЙ, АССОЦИИРОВАННЫХ С ВОЗДЕЙСТВИЕМ ВНЕШНЕСРЕДОВЫХ ФАКТОРОВ СЕЛИТЕБНЫХ ТЕРРИТРИЙ

54 В.М. Боев, Д.А. Кряжев, Л.М. Тулина, А.А. Неплохов ОЦЕНКА КАНЦЕРОГЕННОГО РИСКА ДЛЯ ЗДОРОВЬЯ НАСЕЛЕНИЯ МОНОГОРОДОВ И СЕЛЬСКИХ ПОСЕЛЕНИЙ

61 В.В. Сучков, С.А. Хотимченко, О.В. Сазонова, Д.О. Горбачев, Т.К. Рязанова, Е.А. Семаева РИСК ЗДОРОВЬЮ, СВЯЗАННЫЙ С ПОВЫШЕННЫМ СОДЕРЖДАНИЕМ БЕНЗ(А)ПИРЕНА В ПОЧВЕ

68 С.В. Клейн, С.Ю. Балашов, Е.Г. Степанов, Н.Х. Давлетнуров ОПЫТ ГИГИЕНИЧЕСКОЙ ОЦЕНКИ И МИНИМИЗАЦИИ ВНЕШНЕСРЕДОВОГО РИСКА ЗДОРОВЬЮ В ПЕРИОД ПРОВЕДЕНИЯ В Г. УФЕ ЗАСЕДАНИЯ СОВЕТА ГЛАВ ГОСУДАРСТВ - ЧЛЕНОВ ШОС И ВСТРЕЧИ ГЛАВ ГОСУДАРСТВ И ПРАВИТЕЛЬСТВ БРИКС 
T.N. Govyazina, Yu.A. Utochkin CONTRACEPTIVE BEHAVIOR AS RISK

FACTOR FOR REPRODUCTIVE HEALTH OF JUNIOR STUDENTS ATTENDING A MEDICAL UNIVERSITY

\section{ASSESSMENT AND RISK MANAGEMENT HEALTH AND SAFETY IN MEDICAL HEALTH ORGANIZATION}

V.A. Loginova HYGIENIC ASSESSMENT OF WORKING CONDITIONS AND OCCUPATIONAL RISK FOR WORKERS HEALTH AT RAILWAY TRANSPORT OBJECTS

S.I. Ereniev, O.V. Plotnikova, V.G. Demchenko, N.V. Rudakov BIOLOGICAL, EPIDEMIOLOGICAL, SANITARYHYGIENIC, MEDICAL AND BEHAVIORAL OCCUPATIONAL HEALTH RISK FACTORS FOR STOCK-BREEDERS, VETERINARIES AND WORKERS EMPLOYED

AT MEAT-PROCESSING ENTERPRISES, CONTACTING BRUCELLAR ANIMALS AND INFECTED MEAT

G.G. Badamshina, V.B. Ziatdinov, G.Sh. Isaeva, M.A. Kirillova, S.S. Zemskova ANALYSIS OF RISK FOR INFECTIONS RELATED TO PROVIDING MEDICAL ASSISTANCE N.F. Izmerov, N.I. Izmerova, I.V. Bukhtiyarov, M. Khodzhiev PECULIARITIES OF ADAPTATION REACTIONS IN FEMALE MIGRANTS AND HEALTH DISORDERS RISKS OCCURING AFTER DIFFERENT PERIODS OF STAYING ON MOSCOW REGION TERRITORY

\section{EXPERIMENTAL MODELS AND INSTRUMENTAL SURVEYS FOR RISK ASSESSMENT IN HYGIENE AND EPIDEMIOLOGY}

L.S. Ivashkevich, T.V. Kovshova, O.N. Vashkova, Yu.N. Velentei WORKING OUT PROCEDURES FOR ANALYZING TOXIC ELEMENTS CONTENT IN OIL PRODUCTS AND OIL RAW MATERIALS UING ATOMIC-EMISSION SPECTROMETRY WITH INDUCTIVE-BOUND PLASMA TO ASSESS PRODUCTS SAFETY

L.A. Chesnokova, I.V. Mikhailova, S.I. Krasikov, V.M. Boev INFLUENCE EXERTED BY REDOX-ACTIVE METALS ON OXIDATIVE STRESS EVIDENCE IN AN EXPERIMENT
82 Т.Н. Говязина, Ю.А. Уточкин КОНТРАЦЕПТИВНОЕ ПОВЕДЕНИЕ КАК ФАКТОР РИСКА ДЛЯ РЕПРОДУКТИВНОГО ЗДОРОВЬЯ СТУДЕНТОВ МЕДИКОПРОФИЛАКТИЧЕСКОГО ФАКУЛЬТЕТА МЕДИЦИНСКОГО УНИВЕРСИТЕТА

\section{ОЦЕНКА И УПРАВЛЕНИЕ РИСКАМИ ЗДОРОВЬЮ В МЕДИЦИНЕ ТРУДА И ОРГАНИЗАЦИИ ЗДРАВООХРАНЕНИЯ}

89 В.А. Логинова ГИГИЕНИЧЕСКАЯ ОЦЕНКА УСЛОВИЙ ТРУДА И ПРОФЕССИОНАЛЬНОГО РИСКА ЗДОРОВЬЮ РАБОТНИКОВ НА ОБЪЕКТАХ ЖЕЛЕЗНОДОРОЖНОГО ТРАНСПОРТА

94 С.И. Ерениев, О.В. Плотникова, В.Г. Демченко, Н.В. Рудаков БИОЛОГИЧЕСКИЕ, ЭПИДЕМИОЛОГИЧЕСКИЕ, САНИТАРНО-ГИГИЕНИЧЕСКИЕ, МЕДИЦИНСКИЕ И ПОВЕДЕНЧЕСКИЕ ФАКТОРЫ ПРОФЕССИОНАЛЬНЫХ РИСКОВ ЗДОРОВЬЮ У ЖИВОТНОВОДОВ, ВЕТЕРИНАРНЫХ РАБОТНИКОВ И РАБОТНИКОВ МЯСОПЕРЕРАБАТЫВАЮЩЕЙ ПРОМЫШЛЕННОСТИ, КОНТАКТИРУЮЩИХ С БРУЦЕЛЛЕЗНЫМИ ЖИВОТНЫМИ И ЗАРАЖЕННЫМ СЫРЬЕМ

104 Г.Г. Бадамшина, В.Б. Зиатдинов, Г.Ш. Исаева, М.А. Кириллова, С.С. Земскова АНАЛИЗ РИСКА РАЗВИТИЯ ИНФЕКЦИЙ, СВЯЗАННЫХ С ОКАЗАНИЕМ МЕДИЦИНСКОЙ ПОМОЩИ

109 Н.Ф. Измеров, Н.И. Измерова,

И.В. Бухтияров, М. Ходжиев ОСОБЕННОСТИ АДАПТАЦИОННЫХ РЕАКЦИЙ У ЖЕНЩИН-МИГРАНТОК И РИКИ НАРУШЕНИЯ ЗДОРОВЬЯ ПРИ РАЗЛИЧНОМ ВРЕМЕНИ ПРОЖИВАНИЯ НА ТЕРРИТОРИИ МОСКОВСКОГО РЕГИОНА

ЭКСПЕРИМЕНТАЛЬНЫЕ МОДЕЛИ И ИНСТРУМЕНТАЛЬНЫЕ ИССЛЕДОВАНИЯ ДЛЯ ОЦЕНКИ РИСКА В ГИГИЕНЕ И ЭПИДЕМИОЛОГИИ

117 Л.С. Ивашкевич, Т.В. Ковшова, О.Н. Вашкова, Ю.Н. Велентей РАЗРАБОТКА МЕТОДИКИ АНАЛИЗА СОДЕРЖАНИЯ ТОКСИЧНЫХ ЭЛЕМЕНТОВ В МАСЛОЖИРОВОЙ ПРОДУКЦИИ И МАСЛИЧНОМ СЫРЬЕ С ИСПОЛЬЗОВАНЕМ АТОМНО-ЭМИССИОННОЙ СПЕКТРОМЕТРИИ ДЛЯ ОЦЕНКИ БЕЗОПАСНОСТИ ТОВАРОВ

125 Л.А Чеснокова, И.В. Михайлова, С.И. Красиков, В.М. Боев ВЛИЯНИЕ РЕДОКС-АКТИВНЫХ МЕТАЛЛОВ НА ВЫРАЖЕННОСТЬ ОКИСЛИТЕЛЬНОГО СТРЕССА В ЭКСПЕРИМЕНТЕ 
PREVENTIVE MEDICINE. URGENT ASPECTS OF RISK ANALYSIS

UDC 614.3: 342.9

DOI: 10.21668/health.risk/2017.2.01.eng

\title{
SCIENTIFIC-METHODOLOGICAL APPROACHES TO DESIGNING RISK-ORIENTED MODEL OF CONTROL AND SURVEILLANCE ACTIVITIES IN THE SPHERE OF CONSUMER RIGHTS PROTECTION
}

\author{
N.V. Zaitseva ${ }^{1,2}$, I.V. May ${ }^{1}$, D.A. Kiryanov ${ }^{1}$ \\ ${ }^{1}$ Federal Scientific Center for Medical and Preventive Health Risk Management Technologies, \\ 82 Monastyrskaya Str., Perm, 614045, Russian Federation \\ ${ }^{2}$ Perm State Medical University named after Academician E.A. Wagner, 26 Petropavlovskaya Str., Perm, \\ 614000, Russian Federation
}

We present scientific-methodological approaches to defining risk categories of economic entities which are subject to surveillance in the sphere of consumer rights protection. Risk is suggested to be assessed as a product of violations frequency comprising violations of separate provisions of the law on consumer rights protection detected in the course of scheduled and unscheduled inspections; a number of claims per one detected violation which were satisfied by courts in favor of consumers; each separate case of harm accepted by court in money terms (as a sum of physical and moral damage to health and damage to property); and coefficient of a potential impact scope which differentiates risks for economic entities belonging to micro-, small, medium-sized and large business. Our information sources are official statistic data obtained due to realization of state control in the sphere of consumer rights protection and court practice collected in all the RF regions over 2012-2016. It is shown that a share of economic entities with extremely high risk potential which can cause total material damage to consumers in sums greater than 10 million rubles per year amounts to about $0.15 \%$ of the total number of economic entities (both juridical persons and private entrepreneurs); economic entities with high risk potential account for about $2 \%$. Such groups are made of companies involved in financial markets, share construction services, insurance and tourism. About $23 \%$ of juridical persons and private entrepreneurs can be classified as having low risk potential and they can be excluded from scheduled inspections. Economic entities structure in general corresponds to world practices. It is shown that risk-oriented surveillance model development requires improvements in keeping registers of juridical persons and private entrepreneurs as such registers should contain comprehensive information; it is necessary for correct risk category (or hazard category) determination. It is also vital to work out a regulation on registering cases of moral and property damage to citizens caused by violations of obligatory requirements in the sphere of consumer rights protection. Other ways of protecting consumer rights are becoming especially important; here we first of all mean preventive and procedural ones. Such ways are to be developed and implemented especially widely for spheres of activities which are "risky".

Key words: consumer rights protection, goods, services, risk-oriented surveillance, hazard category, property damage.

State policy in the Russian Federation is goods and services on the Russian market aimed at growth in quantity of such consumer which increase the quality of our population's

(C) Zaitseva N.V., May I.V., Kiryanov D.A., 2017

Nina V. Zaitseva - Academician of the Russian Academy of Sciences, Doctor of Medicine, Professor, Director (e-mail: znv@ fcrisk.ru; tel.: +7 (342) 237-25-34).

IrinaV. May - Doctor of Biological Sciences, Professor, Deputy Director for Research (e-mail: may@fcrisk.ru; tel.: +7 (342) 237-25-47).

Dmitriy A. Kiryanov - Candidate of Technical Sciences, Head of Mathematic Systems and Processes Modeling (e-mail: kda@fcrisk.ru; tel: +7 (342) 237-18-04).

${ }^{1}$ On national system of consumer rights protection: materials of the meeting of the RF State Council Presidium on April 18, 2017. Aveilable at: http://www.kremlin.ru/events/president/news/54328 (28.04.2017). 
life ${ }^{1}$. It can be achieved with various tools; implementation of risk-oriented surveillance model is one of them as it involves consumers health risks management [6]. Risk analysis system has been actively applied worldwide for more than a decade already and its major goal is to increase state surveillance and control efficiency together with lowering administrative barriers for economic entities [9,14-20]. Risk assessment methodology in the Russian Federation is most widely used in banking and financial spheres [1,7-9]; howeve, over the last years it has found wider implementation in environmental protection [2], public healthcare [3,5], sanitaryepidemiologic welfare provision, organizational management, and other spheres [6,11-13].

More than 120,000 scheduled and unscheduled inspections by Rospotrebnadzor regional offices are organized at economic entities annually in order to protect consumer rights and to control compliance of their activities, goods, and services with the legal requirements [4]. Over 2007-2016 scheduled inspections share was on average equal to $44 \%$, ranging from 35.5 to $50 \%$. Annually from 200,000 to 300,000 violations of "On consumer rights protection" Federal Law are detected in the inspections course. Over the last 5 years regular courts have received more than 2,000,000 claims on consumer rights protection. 397,145 cases on the matter were heard in the courts in 2016 only. $68.9 \%$ of the cases were satisfied for benefits of consumers. Since 2012 more than 130 billion rubles were awarded to consumers by the courts. The total recovery sum (including moral damage compensations) has increased 5 times over the last 5 years, from 13.3 billion rubles in 2012 to 42.7 billion rubles in $2016^{2}$.

Clause 8.1 of the RF Federal Law No. 294 " On protection of... rights..." ${ }^{3}$ fixes riskoriented model of control and surveillance activities performed by stated authorities, and Government Order no. $245^{4}$ states it should also apply to the sphere of consumer rights protection.

Both Federal Law No. 294 and the RF Government Order dated August 172016 Nj 806 "On application of risk-oriented approach when organizing certain state control (surveillance) activities (with amendments and additions)" ${ }^{5}$ fix certain principles of riskoriented model design. These principles state that:

- frequency of scheduled inspections at juridical persons and/or private entrepreneurs' enterprises is determined by danger category or risk category;

- criteria of assigning economic entities which are subject to state control (surveillance) into risk categories should allow for probability of violations by juridical persons or private entrepreneurs of the obligatory requirements in the sphere under surveillance (in our case, the sphere of consumer rights protection); they should also allow for gravity of potential negative consequences which possible violations of the

\footnotetext{
${ }^{2}$ As per data given by the Judicial Department of the Supreme Court of the Russian Federation as on February 1, 20172.No.СД-АГ/139, as on April 26, 2017 No.СД-АГ/647.

${ }^{3}$ On protection of juridical persons' and private entrepreneurs' rights when performing state control (surveillance) activities and municipal control: Federal Law passed on December 26,2008 Nj 294- $\$ 3$ with amendments and additions. Available at: http://www.consultant.ru/document/cons doc LAW 83079/ (29.04.2017).

${ }^{4}$ On making amendments into the RF Government Order dated August 17, $2016 \mathrm{Nj}$ 806: the RF Government Order dated March 02, 2017 No. 245. Available at: https://www.consultant.ru/law/hotdocs/49031.html (29.04.2017).

${ }^{5}$ On implementation of risk-oriented approach when organizing specific types of state control (surveillance) and making amendments into certain RF Government documents: Government Order dated August 17, 2016 No. 806. Available at: http://www.consultant.ru/document/cons doc LAW_203819/ (29.04.2017).
} 
stated obligatory requirements can have;

- assessment of potential negative consequences gravity caused by juridical persons and private entrepreneurs violating the obligatory requirements is to be accomplished allowing for possible gravity of potential damages and scope of potential negative consequences prevalence.

Besides, another vital principle in designing new control organization system is risk criteria and risk categories transparency as well as transparency in distribution of the economic entities which are subject to control into risk categories as per probable damage they can cause to the protected values.

A protected value in the sphere of consumer rights protection is a right of goods or services consumers to acquire goods (services) which are safe for their life or health and also to preserve their property. Requirements to a product or service safety can be violated and risks of that are taken into account when juridical persons and private entrepreneurs are assigned into risk categories for implementing sanitary-epidemiologic control and surveillance activities [10]. Here we mostly consider a probability when specific requirements to safety parameters can be violated and gravity of consequences which are proved to be associated with such violations. Gravity is understood as a damage to a specific individual health which can be caused by violations of standards and requirements set forth for a product or service, and potential number of people who can be exposed to consequences of an activity which violates safety requirements.

But at the same time, when we plan riskoriented inspections in the sphere of consumer rights protection we face a problem of accounting risks of property and moral losses by citizens. In relation to that, we assume that scientific and methodical approaches to surveillance objects categorizing in the sphere of consumer rights protection should be based on:

- choice of parameters which are objective, checkable, and individually determined for each juridical person or private entrepreneur under surveillance; these parameters characterize each risk component (probability of the obligatory requirements violation, gravity of such violations' consequences, and the scope of the consequences occurrence);

- working out risk calculation procedure which would allow to obtain comparable results for economic entities involved in variety of activities, which are subject to legal regulation in the sphere of consumer rights protection, for example, hairdressers, or banks and insurance companies;

- giving grounds for risks scale which provides adequate classification of juridical persons and private entrepreneurs which are subject to surveillance.

All the above-mentioned tasks helped us to define our research goal which was to create and to test scientific-methodological approaches to creating a risk-oriented model of control and surveillance activities in the sphere of consumer rights protection.

Mature risk management and assessment system obviously can't exist without a relevant maturity of information decisions on collecting, generalizing and analyzing data as well as without developed intradepartmental processes. Rospotrebnadzor has a wellorganized and maintained departmental statistics system. And it was clearly advisable to fully use the available database which gives impressive possibilities to make analytical generalizations, both for the Russian Federation as a whole and for its separate regions. We took data from the statistical departmental reports "Data on the results of 
federal state surveillance implementation by Rospotrebnadzor regional offices" and used these data as our information basis (form 1, table in the section 3 as per Russian regions over 2013-2016). We considered possibilities to use data on: number of performed scheduled and unscheduled inspections as per spheres of activities; number of detected violations as per various clauses of "On consumer rights protection" Federal Law and technical regulations (again allowing for activity spheres); on number of cases when damage was done to consumers' health and property etc. We paid attention to the fact that departmental statistics contained data on money sums which were awarded by the courts for consumers' benefits (including moral damage compensating).

Juridical persons and private entrepreneurs were classified as per risks of causing potential property damage to goods and services consumers allowing for a sphere of activity which they were involved in. We allowed for recommendations on preferred application of calculation procedure for risk assessment which helps to determine exact risk numerical value as a product of "damage probability" parameter and "damage gravity" parameter [6, page 25]

Data and methods. When working out procedures and assessing risks of damage to consumers in the sphere of consumer rights protection as well as when classifying economic entities we tried to unify approaches for the whole system of control and surveillance activities by the Federal Service on Consumer Rights Protection and Human Well-being. Such approach seems to be reasonable due to the fact that some juridical persons and private entrepreneurs are subject to surveillance both in the sphere of sanitaryepidemiologic well-being and consumer rights protection sphere.
We used departmental statistic data collected over 2012-2016 in 84 regions of the RF. To assess a scope in which this or that economic entity can influence consumers, we assigned a juridical person or a private entrepreneur to "small", "medium-sized", or "large" business.

We determined risk as a product of the following values;

- frequency of violations, detected in the course of scheduled and unscheduled inspections as per separate clauses of the law on consumer rights protection;

- number of claims which were satisfied by the court per one detected violation;

- one case of harm in money terms, accepted by the court (as a sum of physical and moral damage to health and property damage);

- coefficient of scope which differentiated risks for economic entities belonging to micro, small, medium-size and large business.

The basic formula for calculating potential property damage risk which could be caused by an economic entity $\left(R^{i}\right)$ was as follows:

$$
\begin{gathered}
R^{i}=\sum_{j} P_{j}^{i} G_{j}^{i}, \\
G_{j}^{i}=\sum_{j} a_{j}^{i} U^{i} K,
\end{gathered}
$$

where

$P_{j}^{i}$ was frequency of violation of $j$-th clauses of the law on consumer rights protection as per $i$-th activity sphere, detected in the course of scheduled and unscheduled inspections as per 1 inspection;

$G_{j}^{i}$ was gravity of consequences caused by violating the obligatory

$a_{j}^{i}$ was a number of claims accepted by the court related to one detected violation of $j$ th clause of the law on consumer rights protection as per $i$-th activity sphere; 
$U^{i}$ was one case of material and moral damage in money terms accepted by the court as per $i$-th activity sphere;

$K$ was a coefficient of scope which differentiated risks for economic entities belonging to micro-, small, medium-size and large business.

We set frequency of violations detected due to scheduled and unscheduled inspections for economic entities for each separate activity as $95 \%$ percentile of regional distribution of violations detected due to Rospotrebnadzor scheduled and unscheduled inspections over 2012-2016.

If we choose $95 \%$ percentile as violation frequency value it can lead to a certain overestimation of potential risks for most economic entities under surveillance. However, this parameter characterizes this almost maximum potential damage which can be done by an economic entity involved in a certain activity in the Russian Federation at the contemporary stage of the country economic development and the existing level of "compliance with law". Experts in the riskoriented surveillance field formulate potential danger accounting principle and consider it to be obligatory [6, page 25]. If overall social responsibility of business in the country grows than decrease in number of detected (i. e. occurring) violations will inevitably lead to decrease in $95 \%$ percentile of violations frequencies, and, consequently, to lowering risk categories for a number of juridical persons and private entrepreneurs. Besides, if we accept the same violation frequency value for a specific activity it will allow to exclude regional peculiarities of "detectability" of violations in the sphere of consumer rights protection. And such peculiarities do exist. Thus, for example, in 20167.2 violations on average were detected in Sverdlovsk region as per 1 inspection in the sphere of consumer rights protection; 4 violations, in
Bashkortostan and Tula region; 0.9 violations, in Karachai-Cherkess and Chechen Republics [4]. "Check-lists" system introduction, differentiation of obligatory requirements as per damage risks, unification of approaches to registering cases of damage to consumers property, and some other measures will in future help to eliminate all the existing unconformities. But as for now, we treated the above-mention parameter application as an optimal variant to assess probability of the obligatory requirements violation.

We assessed "damage gravity" parameter as a product of several components. We took it as a postulate that not every violation could lead to property damage. The first component in gravity assessment was a probability of actual damage to consumers due to legal requirements violations which was estimated as per number of claims on consumer rights protection issues (both in protecting concrete individuals and in protecting unspecified ones), which were satisfied by the courts for consumers' benefits and attributed to 1 case of the violations detected in the course of inspections. This value was detected as per results of regression analysis when correlations between a number of claims satisfied by the courts and a number of violations of the law on consumer rights protections over 5 years were analyzed and data on all the RF regions were used in the analysis. The approach fully corresponds to the basic requirements set forth by the Government Order No. 806 which demands to allow for possible frequency of potential negative consequences occurrence when obligatory requirements are violated; i.e. this Order correlates violations and damage. We considered claims satisfied by the courts exactly as evidential cases of damage to consumers. We made all the calculations as per activity spheres and it allowed us to 
describe peculiarities of frequency (probability) of property damage occurrence per 1 case of legal requirements violation when various goods or services were offered to consumers.

The second gravity component was one case of material and moral harm in money terms accepted and satisfied by the court. We determined this value as a ratio of the money awarded for consumers benefits to a number of claims satisfied by the court for each activity sphere. To analyze the data, we reduced all the awarded sums as per all claims over 20142016 to comparable values with the help of deflators. $95 \%$ percentile of regional distribution of sums awarded by the courts for consumers' benefits (as per 1 case of damage) was taken as a gravity parameter.

We assessed a scope of an economic entity potential impacts by assigning it to a micro-, small, medium-sized, or a large business. We defined a scope coefficient basing on the ratio between a number of the given enterprises and their annual earnings (up to 60 million rubles for micro-enterprises; up to 400 million for small enterprises; up to 1 billion for medium-sized business; and more than 1 billion rubles for large businesses). Accordingly, scope coefficients for various activity spheres were as follows: 0.6 (microbusiness); 4.0 (small business); 10 (mediumsized business); 100 (large business).

Risk value obtained from the equation was numeric and characterized potential annual property losses by consumers (as a sum per all who suffered them) which could be caused by a specific economic entity involved in a certain sphere of activity in the RF. Risk value was compared with a scale designed by experts (table 1).

Risk assessment for each specific economic entity allowed to assign it to this or that category and to subsequently determine frequency of scheduled control and surveillance activities.

Table 1

Scale for assigning economic entities to risk categories

\begin{tabular}{|c|l|}
\hline Risk categories & \multicolumn{1}{|c|}{ Criteria } \\
\hline Low & $\begin{array}{l}\mathrm{R}<1 \text { thousand rubles } \\
1 \text { thousand rubles } \leq \mathrm{R}<10 \\
\text { thousand rubles }\end{array}$ \\
\hline Average & $\begin{array}{l}10 \text { thousand rubles } \leq \mathrm{R}<100 \\
\text { thousand rubles }\end{array}$ \\
\hline Considerable & $\begin{array}{l}100 \text { thousand rubles } \leq \mathrm{R}<1 \\
000 \text { thousand rubles }\end{array}$ \\
\hline High & $\begin{array}{l}1 \text { thousand rubles } \leq \mathrm{R}<10 \\
000 \text { thousand rubles }\end{array}$ \\
\hline Extremely high & $\mathrm{R} \geq 10$ 000 thousand rubles \\
\hline
\end{tabular}

The system becomes dynamic due to possibility to "increase" or "decrease" a risk category for a juridical person or a private entrepreneur on the basis of the inspection results; this possibility is fixed in the regulations. When a decision on a category change is taken, officials pay attention to occurrence or absence of legal resolutions on administrative offence cases which came into force; orders on temporary suspension and (or) revoke of a license on an activity and orders on eliminating violations of the obligatory requirements set forth by the RF sanitaryepidemiologic legislation.

Primary results. As we applied the suggested approaches in processing actual data obtained in the course of control and surveillance activities it allowed us to reveal that frequency of violations by economic entities of the obligatory requirements in the sphere of consumer rights protection differed greatly for juridical persons and private entrepreneurs involved in different activities. Data on 64 activity spheres (with the highest violations frequency) are given in Table 2. 
Table 2

Frequency of violations as per certain clauses of the law on consumer rights protection (per 1 inspection, 95-percentile over 2012-2016, 84 regions of the RF)

\begin{tabular}{|c|c|c|c|c|c|c|c|c|}
\hline Activity sphere & $\begin{array}{l}\ddot{\mathscr{O}} \\
\stackrel{\vec{U}}{U}\end{array}$ & 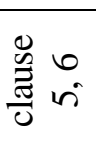 & 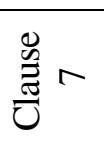 & $\begin{array}{l}0 \\
\frac{0}{0} \\
\frac{0}{0} \\
\frac{1}{0} \\
\frac{1}{\infty}\end{array}$ & $\begin{array}{l}\frac{\tilde{O}}{\vec{J}} \\
\frac{\tilde{J}}{0}\end{array}$ & 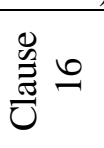 & 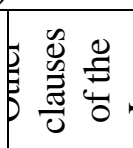 & 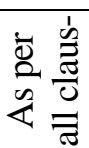 \\
\hline TOTAL, including & 0,35 & 0,16 & 0,23 & 1,56 & 0,13 & 0,21 & 0,48 & 3,13 \\
\hline Retail trade, including & 0,41 & 0,24 & 0,31 & 1,71 & 0,15 & 0,09 & 0,50 & 3,42 \\
\hline food stuffs & 0,45 & 0,27 & 0,34 & 1,61 & 0,16 & 0,04 & 0,38 & 3,25 \\
\hline distance selling & 0,74 & 0,04 & 0,06 & 4,00 & 0,04 & 1,30 & 2,00 & 8,18 \\
\hline per samples & 0,50 & 0,24 & 0,32 & 2,69 & 0,31 & 1,32 & 1,04 & 6,42 \\
\hline Catering & 0,52 & 0,17 & 0,33 & 1,73 & 0,18 & 0,09 & 0,38 & 3,40 \\
\hline Consumer services & 0,44 & 0,08 & 0,14 & 2,10 & 0,18 & 0,53 & 0,76 & 4,23 \\
\hline $\begin{array}{l}\text { Technical services and car repair and } \\
\text { maintenance }\end{array}$ & 0,46 & 0,10 & 0,13 & 3,00 & 0,30 & 0,58 & 1,00 & 5,57 \\
\hline Car parking services & 0,90 & 0,00 & 0,00 & 3,00 & 0,36 & 0,49 & 0,50 & 5,25 \\
\hline Hotels & 0,50 & 0,00 & 0,09 & 3,00 & 0,33 & 0,43 & 0,82 & 5,17 \\
\hline Tourism, including & 0,37 & 0,00 & 0,06 & 2,30 & 0,14 & 1,69 & 1,24 & 5,80 \\
\hline organized children groups & 0,40 & 0,00 & 0,20 & 2,04 & 0,20 & 1,00 & 1,00 & 4,84 \\
\hline Transportation, including & 0,40 & 0,00 & 0,08 & 2,51 & 0,11 & 0,28 & 0,54 & 3,92 \\
\hline air transport & 0,25 & 0,00 & 0,00 & 3,00 & 0,00 & 0,51 & 1,00 & 4,76 \\
\hline urban surface transport & 0,37 & 0,00 & 0,06 & 2,77 & 0,14 & 0,25 & 0,50 & 4,09 \\
\hline Communications, including: & 0,67 & 0,00 & 0,00 & 2,92 & 0,20 & 1,85 & 1,00 & 6,63 \\
\hline wired broadcasting & 0,11 & 0,00 & 0,00 & 2,53 & 0,00 & 1,50 & 0,80 & 4,95 \\
\hline mobile communications & 0,50 & 0,00 & 0,00 & 2,04 & 0,00 & 1,03 & 1,00 & 4,58 \\
\hline data transfer & 0,54 & 0,00 & 0,00 & 3,00 & 0,00 & 1,00 & 1,00 & 5,54 \\
\hline telephone communications & 0,50 & 0,00 & 0,00 & 3,00 & 0,00 & 1,50 & 1,00 & 6,00 \\
\hline Financial activities, including: & 0,20 & 0,00 & 0,00 & 2,00 & 0,03 & 3,86 & 1,31 & 7,39 \\
\hline insurance & 0,33 & 0,00 & 0,00 & 2,88 & 0,00 & 2,83 & 1,47 & 7,51 \\
\hline banking & 0,15 & 0,00 & 0,00 & 2,00 & 0,00 & 5,00 & 1,41 & 8,55 \\
\hline micro-financing & 0,00 & 0,00 & 0,00 & 2,65 & 0,00 & 2,00 & 1,00 & 5,65 \\
\hline Payment services & 0,00 & 0,00 & 0,00 & 2,00 & 0,00 & 1,00 & 1,00 & 4,00 \\
\hline Share construction & 0,00 & 0,00 & 0,00 & 2,22 & 0,00 & 2,72 & 1,61 & 6,55 \\
\hline Communal services & 0,59 & 0,03 & 0,23 & 2,26 & 0,12 & 0,50 & 0,60 & 4,34 \\
\hline Education & 0,31 & 0,01 & 0,06 & 1,78 & 0,14 & 0,80 & 0,56 & 3,66 \\
\hline Health care & 0,40 & 0,03 & 0,16 & 1,99 & 0,13 & 0,63 & 0,57 & 3,92 \\
\hline Real estate agents activities & 0,00 & 0,00 & 0,00 & 2,43 & 0,10 & 2,75 & 1,63 & 6,90 \\
\hline Cinemas & 0,21 & 0,00 & 0,00 & 2,00 & 0,40 & 1,00 & 1,00 & 4,61 \\
\hline Other activities & 0,36 & 0,07 & 0,14 & 1,79 & 0,16 & 0,31 & 0,52 & 3,34 \\
\hline
\end{tabular}

As per data given by Rospotrebnadzor offices over the examined period, requirements set forth by the law on consumer rights protection were most likely to be violated in banking $\left(\mathrm{P}^{95}=8.55\right.$ per 1 inspection) and in distance selling sphere $\left(\mathrm{P}^{95}=8.18\right)$. Violations frequency was also high in insurance $\left(\mathrm{P}^{95}=7.51\right)$. Requirements which were most frequently "vio- lated" included clauses on consumers' right to get correct information about goods, works, services, their producers and/or sellers (clauses 8-10-12) or clauses on terms of contracts which infringed consumers' rights (clause 16). If these requirements are violated it can lead, among other things, to consumers being deluded; such delusions result in inadequate actions in buying 
these products or services and discrepancies between buyers' expectations and actual quality of a product (service).

When the requirements set forth by these clauses of the law are violated it results in most frequent reference of consumers to the courts as they want their interests to be protected. Thus, annually up to 0.6 claims on consumers rights protection accepted by the court are registered per 1 detected violation of clauses 810 and 12 on financial market; i.e. almost each violation is considered to be a case of actual damage done to consumers. References to the courts aimed at consumer right protection and compensations for damages in the spheres of education, healthcare, communications and others are considerably less linked to frequency of legal requirements violations. On average as per all activity spheres, one claim is accepted to be heard at the court per $80-85$ detected violations (Table 3).

Table 3

Number of claims accepted by the courts per 1 detected violation of a clause of the law on consumer rights protection

\begin{tabular}{|c|c|c|c|c|c|c|c|}
\hline Activity sphere & $\begin{array}{l}+ \\
0 \\
0 \\
\stackrel{0}{0} \\
\end{array}$ & $\begin{array}{l}0 \\
0 \\
0 \\
0 \\
0 \\
0 \\
0\end{array}$ & $\begin{array}{l}r \\
0 \\
0 \\
\frac{\tilde{J}}{0}\end{array}$ & 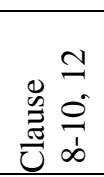 & $\begin{array}{l}= \\
\overline{0} \\
0 \\
心 \\
\\
\end{array}$ & $\begin{array}{l}0 \\
0 \\
0 \\
0 \\
\text { 心 } \\
\end{array}$ & 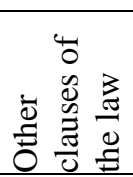 \\
\hline TOTAL & 0,043 & 0,039 & 0,000 & 0,000 & 0,000 & 0,158 & 0,012 \\
\hline including & & & & & & & \\
\hline Retail trade, including & 0,046 & 0,000 & 0,000 & 0,002 & 0,000 & 0,097 & 0,012 \\
\hline food stuffs & 0,021 & 0,000 & 0,000 & 0,000 & 0,000 & 0,033 & 0,007 \\
\hline distance selling & 0,066 & 0,441 & 0,000 & 0,005 & 0,000 & 0,000 & 0,010 \\
\hline per samples & 0,287 & 0,000 & 0,046 & 0,000 & 0,000 & 0,212 & 0,040 \\
\hline Catering & 0,000 & 0,020 & 0,000 & 0,000 & 0,000 & 0,000 & 0,008 \\
\hline Consumer services & 0,015 & 0,036 & 0,000 & 0,005 & 0,000 & 0,024 & 0,075 \\
\hline $\begin{array}{l}\text { Technical services and car repair and } \\
\text { maintenance }\end{array}$ & 0,000 & 0,000 & 0,000 & 0,000 & 0,012 & 0,000 & 0,000 \\
\hline Car parking services & 0,000 & 0,000 & 0,000 & 0,015 & 0,000 & 0,000 & 0,000 \\
\hline Hotels & 0,015 & 0,036 & 0,000 & 0,005 & 0,000 & 0,024 & 0,075 \\
\hline Tourism & 0,083 & 0,000 & 0,000 & 0,000 & 0,000 & 0,051 & 0,071 \\
\hline Transportation & 0,043 & 0,039 & 0,000 & 0,000 & 0,000 & 0,158 & 0,012 \\
\hline inner water transport & 0,000 & 0,000 & 0,000 & 0,000 & 0,000 & 0,490 & 0,000 \\
\hline air transport & 0,000 & 3,611 & 0,000 & 0,000 & 0,000 & 0,000 & 0,000 \\
\hline urban transport & 0,043 & 0,039 & 0,000 & 0,000 & 0,000 & 0,158 & 0,012 \\
\hline Communications, including & 0,000 & 0,000 & 0,000 & 0,000 & 0,000 & 0,000 & 0,046 \\
\hline wired broadcasting & 0,444 & 0,000 & 0,000 & 0,000 & 0,000 & 0,000 & 0,000 \\
\hline mobile communications & 0,000 & 0,000 & 0,000 & 0,000 & 0,000 & 0,000 & 0,046 \\
\hline telematic communications & 0,000 & 0,000 & 0,000 & 0,000 & 0,000 & 0,000 & 0,046 \\
\hline data transferring & 0,000 & 0,456 & 0,000 & 0,000 & 0,000 & 0,000 & 0,046 \\
\hline telephone communications & 0,000 & 0,000 & 0,000 & 0,000 & 0,000 & 0,000 & 0,046 \\
\hline Financial activities, including: & 0,041 & 0,000 & 0,000 & 0,602 & 0,000 & 0,148 & 0,000 \\
\hline insurance & 0,000 & 0,000 & 0,000 & 0,663 & 0,000 & 0,088 & 0,000 \\
\hline banking & 0,000 & 0,000 & 0,000 & 0,608 & 0,000 & 0,164 & 0,000 \\
\hline micro-financing & 0,186 & 0,000 & 0,000 & 0,033 & 1,041 & 0,005 & 0,049 \\
\hline Share construction & 0,000 & 0,000 & 0,000 & 0,000 & 0,000 & 0,027 & 0,645 \\
\hline Communal services & 0,000 & 0,000 & 0,000 & 0,123 & 0,000 & 0,000 & 0,000 \\
\hline Education & 0,006 & 0,000 & 0,000 & 0,001 & 0,000 & 0,007 & 0,003 \\
\hline Healthcare & 0,006 & 0,000 & 0,000 & 0,001 & 0,000 & 0,007 & 0,003 \\
\hline Real estate agents services & 0,000 & 0,000 & 0,000 & 0,000 & 0,458 & 0,035 & 0,000 \\
\hline Other spheres & 0,000 & 0,000 & 0,000 & 0,000 & 0,000 & 0,080 & 0,050 \\
\hline
\end{tabular}


As we analyzed average sums awarded by the courts for benefits of products and services consumers per various spheres of disputed legal relations we revealed that the greatest sums were awarded in share construction (304.8 thousand rubles) ${ }^{6}$. The smallest sums were awarded in communal services (25.5 thousand rubles), services provided in the sphere of culture and rest (38 thousand rubles) and communications (54 thousand rubles).

An average awarded sum per 1 satisfied claim in 2016 amounted to 112.4 thousand rubles in disputes arising from contracts with financial-lending organizations (106.8 thou- sand rubles in 2015, 98.7 thousand rubles in 2014): it amounted to 134.3 thousand rubles per 1 satisfied claim in disputes arising from contracts in the sphere of trade, services etc.

The obtained data gave grounds for risks assessment of economic entities which were included in the federal register of juridical persons and private entrepreneurs and were subject to surveillance in the sphere of consumer rights protection. Risks assessment based on the suggested approaches helped us to obtained the data which are generalized in Table 4.

Calculated values of property losses risk (including compensated moral harm) in specific Spheres of activities (data are generalized)

\begin{tabular}{|c|c|c|c|c|}
\hline \multirow{2}{*}{ Activity sphere } & \multicolumn{4}{|c|}{ Property losses risk, rubles/year (risk category) } \\
\hline & Micro & Small & Medium-sized & large \\
\hline Retailing & $\begin{array}{c}5.5 \\
\text { (5;moderate) }\end{array}$ & $\begin{array}{c}36.4 \\
\text { (4;average) }\end{array}$ & $\begin{array}{c}91.1 \\
\text { (4;average) }\end{array}$ & $\begin{array}{c}911.2 \\
\text { (3; considerable) }\end{array}$ \\
\hline catering & $\begin{array}{c}0.7 \\
(6 ; \text { low }) \\
\end{array}$ & $\begin{array}{c}4.6 \\
(5 ; \text { moderate }) \\
\end{array}$ & $\begin{array}{c}11.5 \\
\text { (4;average) }\end{array}$ & $\begin{array}{c}114.9 \\
(3 ; \text { considerable })\end{array}$ \\
\hline Consumer services & $\begin{array}{c}13.5 \\
\text { (4;average) }\end{array}$ & $\begin{array}{c}89.7 \\
\text { (4;average) } \\
\end{array}$ & $\begin{array}{c}224.2 \\
(3 ; \text { considerable })\end{array}$ & $\begin{array}{c}2242.4 \\
(2 ; \text { high })\end{array}$ \\
\hline Technical maintenance of vehicles & $\begin{array}{c}1.7 \\
\text { (5;moderate) } \\
\end{array}$ & $\begin{array}{c}11.5 \\
\text { (4;average) }\end{array}$ & $\begin{array}{c}28.7 \\
\text { (4;average) } \\
\end{array}$ & $\begin{array}{c}287.4 \\
\text { (3; considerable) }\end{array}$ \\
\hline Hotels & $\begin{array}{c}6.9 \\
(5 ; \text { moderate }) \\
\end{array}$ & $\begin{array}{c}46.1 \\
\text { (4;average) } \\
\end{array}$ & $\begin{array}{c}115.3 \\
(3 ; \text { considerable }) \\
\end{array}$ & $\begin{array}{c}1152.8 \\
(2 ; \text { high }) \\
\end{array}$ \\
\hline Tourism & $\begin{array}{c}37.4 \\
\text { (4;average) }\end{array}$ & $\begin{array}{c}249.2 \\
\text { (3; considerable) }\end{array}$ & $\begin{array}{c}623.0 \\
\text { (3; considerable) }\end{array}$ & $\begin{array}{c}6230.3 \\
\text { (2; high) }\end{array}$ \\
\hline Transportation & $\begin{array}{c}5.6 \\
\text { (5;moderate) }\end{array}$ & $\begin{array}{c}37.3 \\
\text { (4;average) }\end{array}$ & $\begin{array}{c}93.1 \\
\text { (4;average) }\end{array}$ & $\begin{array}{c}931.3 \\
\text { (3; considerable) }\end{array}$ \\
\hline Communications & $\begin{array}{c}1.2 \\
\text { (5;moderate) }\end{array}$ & $\begin{array}{c}7.9 \\
\text { (5;moderate) }\end{array}$ & $\begin{array}{c}19.7 \\
\text { (4;average) }\end{array}$ & $\begin{array}{c}197.4 \\
\text { (3; considerable) }\end{array}$ \\
\hline Financial market & $\begin{array}{c}201.7 \\
(3 ; \text { considerable })\end{array}$ & $\begin{array}{c}1344.6 \\
\text { (5; high) }\end{array}$ & $\begin{array}{c}3361.4 \\
\text { (5; high) }\end{array}$ & $\begin{array}{c}33614.2 \\
\text { (1;extremely } \\
\text { high) }\end{array}$ \\
\hline Share construction & $\begin{array}{c}825.8 \\
(3 ; \text { considerable })\end{array}$ & $\begin{array}{c}5505.1 \\
(5 ; \text { high })\end{array}$ & $\begin{array}{c}\mathbf{1 3 7 6 2 . 8} \\
\text { (1;extremely } \\
\text { high) }\end{array}$ & $\begin{array}{c}\mathbf{1 3 7 6 2 8 . 5} \\
\text { (1;extremely } \\
\text { high) }\end{array}$ \\
\hline Communal services & $\begin{array}{c}29.1 \\
\text { (4;average) }\end{array}$ & $\begin{array}{c}193.9 \\
(3 ; \text { considerable })\end{array}$ & $\begin{array}{c}484.8 \\
(3 ; \text { considerable })\end{array}$ & $\begin{array}{c}4847.8 \\
\text { (5; high) } \\
\end{array}$ \\
\hline Education & $\begin{array}{c}0.6 \\
(6 ; \text { low })\end{array}$ & $\begin{array}{c}3.7 \\
(5 ; \text { moderate }) \\
\end{array}$ & $\begin{array}{c}9.3 \\
(5 ; \text { moderate }) \\
\end{array}$ & $\begin{array}{c}93.1 \\
\text { (4;average) }\end{array}$ \\
\hline Healthcare & $\begin{array}{c}2.4 \\
\text { (5;moderate) }\end{array}$ & $\begin{array}{c}15.9 \\
\text { (4;average) }\end{array}$ & $\begin{array}{c}39.7 \\
\text { (4; average) }\end{array}$ & $\begin{array}{c}397.4 \\
(3 ; \text { considerable })\end{array}$ \\
\hline
\end{tabular}

${ }^{6}$ As per data given bv the Judicial Department of the RF Supreme Court on April 26. 2017 No. СД-АГ/647. 
We analyzed distribution of almost 1.5 million juridical persons and private entrepreneurs included in the federal register per categories of property damage risks. Our analysis revealed that a share of economic entities which could be assigned into extremely high risk category in the sphere of consumer rights protection amounted to not more than $0.15 \%$ (Figure). They were mostly large juridical persons operating on financial markets and in share construction sphere.

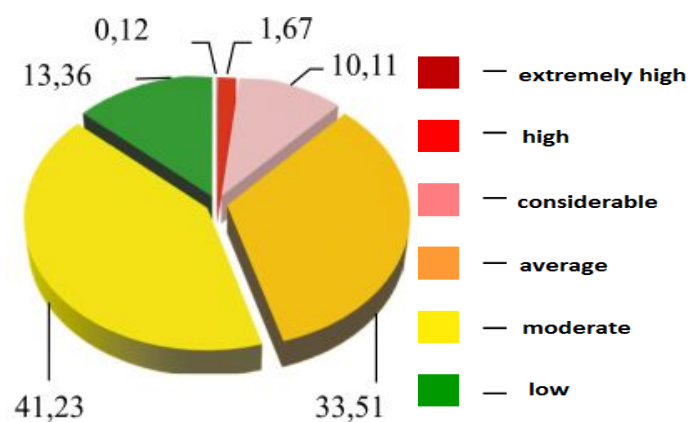

Figure. Structure of juridical persons and private entrepreneurs involved in activities which are subject to regulations by the Federal Law "On consumer rights protection", as per categories of potential property losses risks for goods and services consumers

A share of high risk objects was also low and amounted to about $2 \%$. This group, apart from financing and construction, comprised juridical persons and private entrepreneurs who provided insurance and tourism services.

About $13 \%$ of all the economic entities under surveillance can be assigned into the 6th category and they will be excluded from the inspections schedule. But still unscheduled inspections of these objects can take place under circumstances set forth by the law.

We should note that the structure of the objects under surveillance as per risk categories fully corresponds to the data given in foreign literature on risk-oriented state surveillance. We should also point out that it is advis- able to revise this structure and the criteria of assigning economic entities into risk categories every 3-5 years in the scope of the whole country. Such revision seems reasonable due to changes in legislation on consumer rights protection, court practices, changes in violations frequency or awarded sums (even in comparable prices) etc.

Conclusion. In general, economic entities assignment into various categories as per damage risks helps to reasonably concentrate surveillance and control authorities efforts on economic entities with extremely high and high risks via changes in surveillance activities frequency. But still it is obvious that implementation of risk-oriented model in the sphere of consumer rights protection requires its further improvements.

It seems vital to improve generation and maintenance of juridical persons and private entrepreneurs register which should contain comprehensive information for correct risk category determination (or danger category). Such register is seen as a component of the state information resource in the sphere of consumer rights protection (http://zpp.rospotrebnadzor.ru). The latter should provide consumers with actual and relevant information which is obtained due to aggregation and analysis of a great number of state and private data sources, such as statistics, data on granted permissions, licenses, confirmations of products compliance and registration, marking, goods' origin and movement, bankruptcies, goods withdrawal, inspection results, laboratory tests results, other judicial and administrative law enforcement etc.

It is also very important to create a regulation on registering cases of moral harm and property damage to citizens due to violations of obligatory requirements in the sphere of consumer rights protection. 
Risk-oriented approaches implementation requires development of tools aimed at goods traceability for fixing inspections procedures which are required for checking activities of enterprises directly involved in manufacturing, selling, delivering, storing, transportation, and destruction of unsafe products.

There are other ways to protect consumer rights and they are becoming considerably vital. First of all, we mean preventive activities (clarifications, warnings about typical violations, consulting and informing) and proceedings (reference to the court with claims on protecting unspecified individuals and participation in the court hearings to give statement on a case). Such forms are to be created and developed especially actively in the spheres of "risky activities". First of all, it concerns financial services market and share construction.

Extremely vital task is to perform system analysis of the productivity and efficiency of surveillance and control activities in the sphere of consumer rights protection which already apply risk-oriented approaches.

Implementation of the set of activities which includes risk-oriented surveillance model application will allow not only to increase efficiency of the national consumer rights protection system enhancing consumers' capabilities and guarantees, but also to create additional stimuli for social and economic development and for life quality growth in Russia.

\section{References}

1. Adamskaya L.V., Zhelenkova E.E., Ivleva E.I. Vnedrenie kompleksa mer pri provedenii riskorientirovannogo kontrolya i nadzora [Implementing a set of activities when realizing risk-oriented control and surveillance]. Rossiiskaya nauka i obrazovanie segodnya: problemy i perspektivy, 2016, vol. 11, no. 4, pp. 26-28 (in Russian).

2. Babina Yu.V. Izmeneniya $\mathrm{v}$ zakonodatel'stve o gosudarstvennom ekologicheskom nadzore [Changes in legislation on state ecological surveillance]. Ekologiya proizvodstva, 2015, no. 9, pp. 24-31 (in Russian).

3. Berseneva E.A., Cherkasov S.N., Meshkov D.O. Metodicheskie podkhody k klassifikatsii ob"ektov nadzora po velichine riska [Conceptual approaches to creation risk-focused model of supervision objects classification]. Byulleten' Natsional'nogo nauchno-issledovatel'skogo instituta obshchestvennogo zdorov'ya imeni N.A. Semashko, 2016, no. 3, pp. 14-24 (in Russian).

4. Zashchita prav potrebitelei v Rossiiskoi Federatsii v 2016 godu: Gosudarstvennyi doklad [Consumer rights protection in the Russian Federation in 2016: State report]. Moscow, Federal'naya sluzhba po nadzoru v sfere zashchity prav potrebitelei i blagopoluchiya cheloveka Publ., 2017, 283 p. (in Russian).

5. Kolokolov A.V. Aktual'nost' vnedreniya risk-orientirovannogo podkhoda pri provedenii kontrol'no-nadzornykh meropriyatii $\mathrm{v}$ sfere zdravookhraneniya [Actuality of implementing risk-oriented approach in the course of carrying out control and surveillance measures in the healthcare industry]. Meditsinskii al'manakh, 2016, vol. 44, no. 4, pp. 10-13 (in Russian).

6. Kontrol'no-nadzornaya i razreshitel'naya deyatel'nost' v Rossiiskoi Federatsii: Analiticheskii doklad - 2016 [Control-surveillance and licensing activity in the Russian Federation: Analytical report 2016]. Available at: https: //publications.hse.ru/books/204071253 (02.04.2017) (in Russian).

7. Krivoshapova S.V. Nekotorye aspekty metodologii perekhoda k soderzhatel'nomu (riskorientirovannomu) nadzoru [Some aspects of the methodology of passage to the meaningful (riskoriented) supervision]. Territoriya novykh vozmozhnostei. Vestnik Vladivostokskogo gosudarstvennogo universiteta ekonomiki i servisa, 2009, no. 2, pp. 22 (in Russian).

8. Manuilenko V.V. Realizatsiya risk-orientirovannoi kontseptsii otsenki effektivnosti ekonomicheskogo kapitala $\mathrm{v}$ integrirovannoi sisteme upravleniya bankovskimi riskami [Implementation of risk oriented concept in assessing economic capital efficiency in an integrated system of bank risks management]. Finansy i kredit, 2013, vol. 562, no. 34, pp. 2-8 (in Russian). 
9. Petukhova K.A. Praktika vnedreniya instrumentov upravleniya riskami v gosudarstvennom upravlenii zarubezhnykh stran: osnovnye standarty i lokal'nye dokumenty [Implementation practices for risk management techniques in public management of foreign countries: basic standards and local documents]. Problemy analiza riska, 2014, vol. 11, no 6, pp. 6-21 (in Russian).

10. Popova A.Yu., Bragina I.V., Simkalova L.M., Mitrokhin O.V., Khmura M.V., Zaitseva N.V., May I.V., Shur P.Z., Kiryanov D.A., Chigvintsev V.M., Kamaltdinov M.R., Sedusova E.V., Parfenov A.V., Romanenko K.V., Kuz'min S.V., Dikonskaya O.V., Gurvich V.B., Sboev A.S., Khoroshavin V.A., AkimovaL.N. Risk-orientirovannaya model' kontrol'no-nadzornoi deyatel'nosti v sfere obespecheniya sanitarno-epidemiologicheskogo blagopoluchiya. Klassifikatsiya vidov deyatel'nosti i khozyaistvuyushchikh sub"ektov po potentsial'nomu risku prichineniya vreda zdorov'yu cheloveka dlya organizatsii planovykh kontrol'no-nadzornykh meropriyatii: Metodicheskie rekomendatsii [Risk-oriented model of control and surveillance activity in the sphere of providing sanitary-epidemiologic well-being. Classification of activities and economic entities as per potential risks of human health damage for organizing scheduled control and surveillance inspections: Methodical guidelines]. Moscow, Federal'naya sluzhba po nadzoru v sfere zashchity prav potrebitelei i blagopoluchiya cheloveka Publ., 2014, 69 p. (in Russian).

11. Semenov S.V., Chaplinskii A.V. O sovershenstvovanii pravovogo regulirovaniya sistemy gosudarstvennogo i munitsipal'nogo kontrolya $\mathrm{v}$ Rossii [On the improvement of the legal regulation of the system of state and municipal control in Russia].Voprosy gosudarstvennogo i munitsipal'nogo upravleniya, 2014, no. 4, pp. 118-135 (in Russian).

12. Sokolov D.V. Klassifikatsiya riskov, kak mnogozadachnyi instrument risk-menedzhmenta organizatsii [Risk classification as a multi-task tool of organizational risk-management]. Upravlenie ekonomicheskimi sistemami: elektronnyi nauchnyi zhurnal, 2011, no. 30, pp. 11. Available at: http: //uecs.ru/uecs30-302011/item/489 (30.04.2017) (in Russian).

13. Chaplinskii A.V., Plaksin S.M. Upravlenie riskami pri osushchestvlenii gosudarstvennogo kontrolya v Rossii [Risk Management in the State Control in Russia]. Voprosy gosudarstvennogo i munitsipal'nogo upravleniya, 2016, no. 2, pp. 7-29 (in Russian).

14. Bender W.J., Ayyub B.M. Risk-based cost control for construction. AACE International Transactions, 2000, pp. 11-14.

15. Cameron J.W. Managing Risk Across The Public Sector: Good Practice Guide. Auditor General Victoria, 2004, pp. 1-8 p.

16. Hampton P. Reducing administrative burdens: effective inspection and enforcement. London, 2005, 147 p. Available at: news.bbc.co.uk/nol/shared/bsp/hi/pdfs/bud05hampton_150305_640.pdf (12.10.2014).

17. Leeves G.D., Herbert R.D. Economic and environmental impacts of pollution control in a systemof environment and economic interdependence. Chaos, Solitons\& Fractals, 2002, vol. 13, no. 4, pp. 693-700.

18. Linkage methods for environment and health analysis: general guidelines, a report of the Health and Environment Analysis for Decision-Making (HEADLAMP) project / United Nations Environment Programme, United States Environmental Protection Agency. Geneva, World Health Organization, 1996, 136 p. Available at: http: //apps.who.int/iris/handle/10665/60978 (01.02.2017).

19. Powell C., Laxton's Guide to Risk Analysis and Management, Laxton's Publishers, Jordan Hill, Oxford, 1996, $116 \mathrm{p}$.

20. Ni M., McCalley J.D., Villal V., Tayyib T., Online Risk-Based Security Assessment. IEEE Transactions on Power Systems, 2003, vol. 18, no. 1, pp. 258-265.

Zaitseva N.V., May I.V., Kiryanov D.A. Scientific-methodological approaches to designing riskoriented model of control and surveillance activities in the sphere of consumer rights protection. Health Risk Analysis, 2017, no. 2, pp. 4-15. DOI: 10.21668/health.risk/2017.2.01.eng

Received: 02.03.2017

Accepted: 15.05 .2017

Published: 30.06 .2017 
UDC 614/5: 644.36

DOI: 10.21668/health.risk/2017.2.02.eng

\title{
HEALTH RISKS OCCURRING WHEN COLOR IS PERCEPTED UNDER LED LIGHTING
}

\author{
V.A. Kaptsov ${ }^{1}$, V.N. Deinego ${ }^{2}$ \\ ${ }^{1}$ All-Russian Research Institute of Railway Hygiene, 1 Pakgauznoe Shosse Str., Bldg. 1, Moscow, 125438, Russian Faderation \\ ${ }^{2}$ New energy technologies, 100 Novaya Str., Skolkovo, Moscow region, 143025, Russian Federation
}

The article deals with problems of color perception under LED lighting. We revealed that inadequate perception of a signal color by a driver led to greater risks of transport accidents. We reviewed both Jung-Helmholtz three-color hypothesis and a modern one based on fiber-optical approach to functioning of "Mueller cells and cones" system. We made an attempt to explain a number of effects related to visibility curves and time delays when defining color of light signals. Our research on assessing influence exerted by LED lighting on functional state and working capacity of railway workers during which we applied occupational selection techniques revealed negative changes. We proved there was a decrease in functional resistance to color sense between red and green signals as well as longer response time for complicated sight-motor reaction and significant decrease in readiness to emergency actions (resistance to monotony) in examined individuals. The article also contains data on time peculiarities which are characteristic for defining signals color in relation to red signal $(650 \mathrm{~nm})$. We showed that when red color LEDs with wave length much shorter than $650 \mathrm{~nm}$ were used in signaling devices it caused risks of inadequate color detection, longer reaction to inhibiting signals, and greater possibility of transport accidents and negative events in everyday life. These peculiarities should be taken into account when designing traffic lights and other signaling devices which provide transport safety. We also proved that signaling traffic lights for transport systems should be designed allowing for physiology of color perception by a human visual analyzer; application of LEDs with wave length shorter than $650 \mathrm{~nm}$ should be absolutely excluded.

Key words: LED lighting, color, traffic lights, LEDs, Mueller cells, cones, red light, fiber-optical eye system.

The nature speaks to the man using the language of environmental colors. At first sight, a color may seem to be easy to understand. But in reality color signals contain certain information and exert significant influence on our life changing our mood, emotions, and the way we feel ourselves. Color sometimes manages life itself, for example, when inadequate color determination in perception of warning and inhibit transport signals occurs. Color is a language of our life. We are not always able to translate it but we feel it inside and our instincts make us follow its laws. Our reactions to color are programmed in our genes; our love for certain colors changes depending on the world and our self-sense.

A sight object is visible. Aristotle noted in his works that "...what we see is color. Color belongs to something which is visible in itself; in itself not meaning that it is its essence to be visible, but meaning that it in its nature has the reasons which make it visible. Any color is something that moves really transparent things and it is its true nature. That is why we cannot see light without color, and any color of each object is visible under light". Nowadays a paradigm based on Jung-Helmholtz three-color hypothesis is widely spread among ophthalmologists and light technicians; they use it to describe a color sense model [6]. As per this hypothesis, to get the best determination, color image is to be focused into a hole where the cones density is the greatest. To achieve this, the eye pupil is to react adequately to lighting spectrum which a color object is located in. Under LED lighting a pupil diameter is greater

(C) Kaptsov V.A., Deinego V.N., 2017

Valeriy A. Kaptsov - Corresponding Member of Russian Academy of Sciences, Doctor of Medical Sciences, prof., Head of the Occupational Health Department (e-mail: kapcovva39@ mail.ru; tel.: + 7 (499) 153-36-28).

Vitaly N. Deinego - Light technique project manager (e-mail: aet@aetechnologies.ru; tel.: + 7 (495) 280-76-07). 
than under sunlight and it doesn't provide $100 \%$ determination of an object color $[1-3,5,14$ $16]$.

Allowing for the influence exerted by LED light spectrum on the eye functions and locomotive drivers health, experts from the AllRussian Research Institute of Railway Hygiene of Rospotrebnadzor accomplished the research on impacts exerted by diffused LED light and luminous light from regular lamps on psychophysiological state of a man. The research was initiated by "Russian Railways" PLC. Working places of an experimental plant and all the lamps were certified by the leading technical experts from All-Russian Research Institute of Railway Hygiene and "Russian Railways" PLC.

The accomplished research on assessing influence exerted by LED lighting on functional state and working capacity of railway workers with application of certified occupational selection techniques revealed negative changes. Thus, functional resistance to color sense of red and green signals reduced, response time of a complicated sight-motor reaction became longer, and readiness to emergency actions (resistance to monotony) in all the examined people decrease significantly.

Experts from Yuzhno-Uralskiy State University also noted that volunteers aged 20-25 had poorer light and color sense at the end of the performed research on assessing influence exerted by LED lighting on the human visual analyzer. This peculiarity is important for a number of occupations, notably, surgeons, car drivers, bikers, traffic controllers and locomotive drivers, atomic power station operators, as well as operators at specialized objects of the Defense Ministry. Inadequate color determination increases emergency risks; such emergencies can have various gravity, for a man and population as a whole (when incidents at atomic power stations occur). Therefore, an issue of adequate color sense when receiving light signals is truly vital.

If we take passers-by and city transport drivers, we can say that it is quite enough for them to correctly react to three color signals: red, yellow, and green. Railway workers are to perceive correctly and to react adequately to the whole color spectrum. Thus, "Guidelines on signaling system functioning at railroads in the Russian Federation" fixes the following signals:

- one green signal - «Movement with set speed is allowed»;

- one yellow flashing signal - «Movement with set speed is allowed; the next traffic light is open and it is required to pass it at slower speed»;

- one yellow light - «movement is allowed with readiness to stop; the next traffic light is closed»;

- two yellow lights, the upper one is flashing, - «It is allowed to pass the traffic light with slower speed; the train goes through the switch; the next traffic light is open»;

- two yellow lights - «It is allowed to pass the traffic light with and readiness to stop at the next traffic light; the train goes through the switch»;

- one moon-white flashing light allows a train to go through a traffic light with red color signal (or without any signal) and move to the next traffic light (or up to the last stake when going into a way without the output signal) at a speed not faster than $20 \mathrm{~km} / \mathrm{hour}$;

- one red light $-\ll$ Stop! It is prohibited to pass the signal».

A lot of works are dedicated to color signals perception $[4,8,9]$. Most of such works deal with red color signals with wave length considerably shorter than 650 nanometers. Figure 1 shows coordinates for red color coloration and wave length from 610 to 700 nanometers.

M.J. Flannagan, D.F. Blower and J.M. Devonshire in their work [9] determine red light with coloration coordinates - 0,$66 ; 0,34$, it corresponds to a wave shorter than 610 nanometers (Tables 1, 2).

Ju. Luoma et al. [8] determine red light with coloration coordinates $-0,715 ; 0,283$, it corresponds to a wave shorter than 636 nanometers. Figure 2 shows light sources spectra which were used in the research. Table 3 details photometric values for LED lamps. 


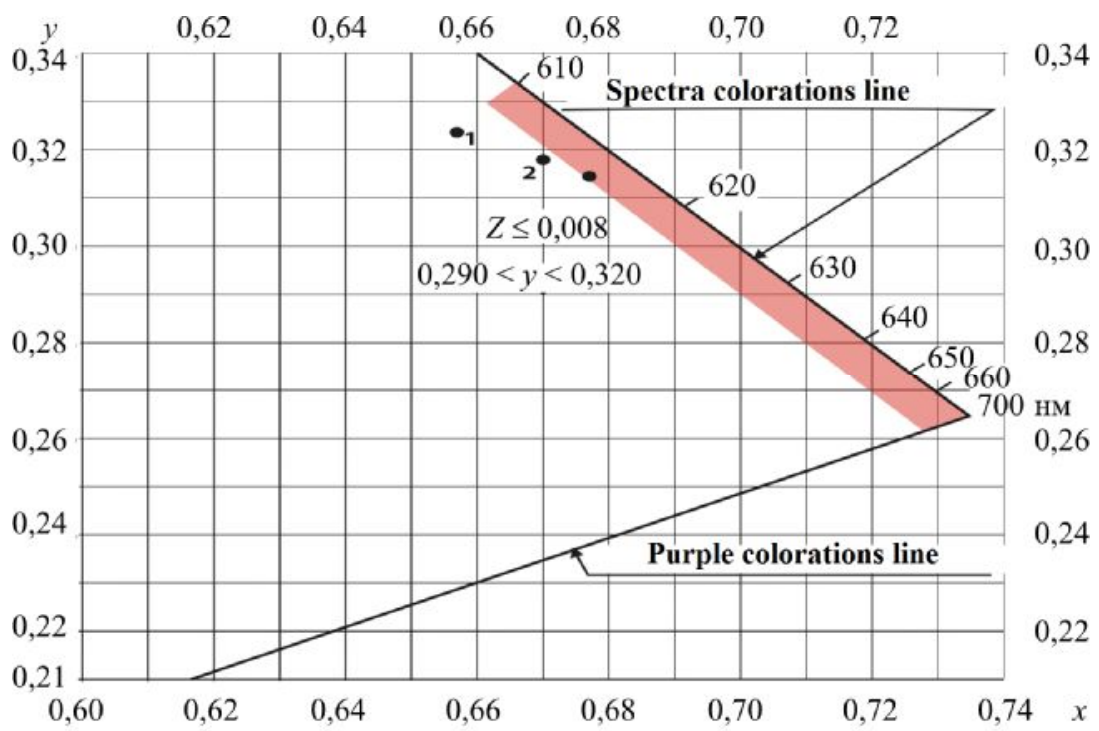

Figure 1. Coloration coordinates for red light

Table 1

Average lamp brightness at corresponding coloration coordinates

\begin{tabular}{|l|c|c|c|c|}
\hline \multirow{2}{*}{ Lamp } & \multicolumn{2}{c|}{ Brightness $(c d)$} & \multicolumn{2}{c|}{ Coloration coordinates } \\
\cline { 2 - 5 } & Without filter & With filter & $X$ & $Y$ \\
\hline Yellow turning signal & 130 & 30 & 0,57 & 0,43 \\
\hline Red turning signal & 130 & 79 & 0,66 & 0,34 \\
\hline Red stop-signal (at an engine level) & \multicolumn{2}{|c|}{81} & 0,66 & 0,34 \\
\hline Red stop-signal (above an engine level) & \multicolumn{2}{|c|}{25} & 0,66 & 0,34 \\
\hline
\end{tabular}

Table 2

Percentage of prompt and correct replies as well as slow and incorrect replies depending on color of signals detailed in Table 1

\begin{tabular}{|l|c|c|}
\hline \multirow{2}{*}{\multicolumn{1}{|c|}{ Reply }} & \multicolumn{2}{c|}{ Signal color } \\
\cline { 2 - 3 } & red & yellow \\
\hline Prompt and correct & 89,8 & 95,9 \\
\hline Slow or incorrect & 10,2 & 4,1 \\
\hline
\end{tabular}

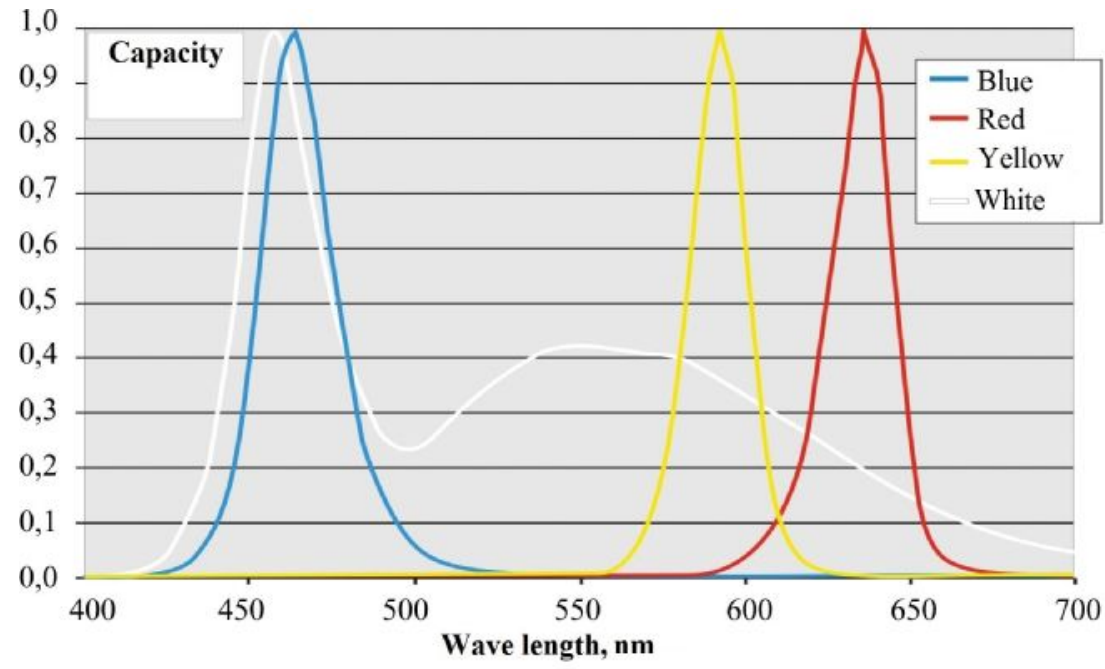

Figure 2. Spectra of blue, red, yellow, and white LEDs 
Table 3

Photometric values for LED lamps

\begin{tabular}{|c|c|c|c|c|c|}
\hline \multirow{2}{*}{ LED color } & \multirow{2}{*}{$S / P$} & \multirow{2}{*}{$\begin{array}{l}\text { Wave length } \\
\text { (nm) }\end{array}$} & \multirow{2}{*}{ Intensity } & \multicolumn{2}{|c|}{ Light intensity } \\
\hline & & & & At photooptic sight $(c d)$ & At night sight $(c d)$ \\
\hline \multirow{2}{*}{ Blue } & \multirow{2}{*}{16,4} & \multirow{2}{*}{464} & High & 1,444 & 23,617 \\
\hline & & & Low & 604 & 9,878 \\
\hline \multirow{2}{*}{ Red } & \multirow{2}{*}{0,069} & \multirow{2}{*}{636} & High & 4,260 & 295 \\
\hline & & & Low & 2,112 & 146 \\
\hline \multirow{2}{*}{ Yellow } & \multirow{2}{*}{0,246} & \multirow{2}{*}{592} & High & 2,060 & 507 \\
\hline & & & Low & 1,276 & 314 \\
\hline \multirow{2}{*}{ White } & \multirow{2}{*}{2,52} & \multirow{2}{*}{$\cdots$} & High & 5,988 & 15,107 \\
\hline & & & Low & 2,320 & 5,53 \\
\hline
\end{tabular}

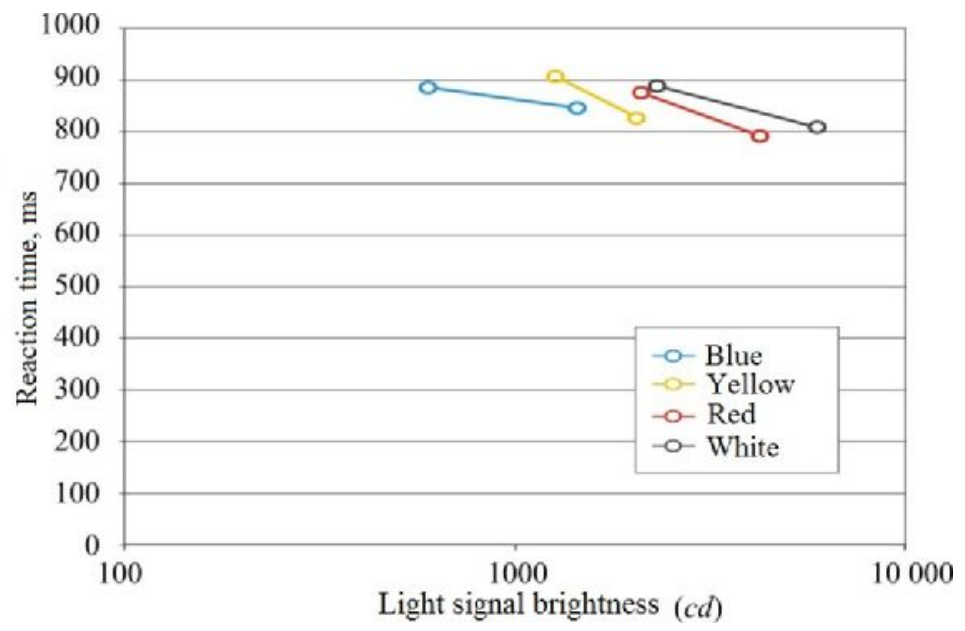

Figure 3. Time of reaction to light signal

Minimal reaction time is registered in case of red light with wave length equal to 636 nanometers (Figure 3) [8].

Modern red LEDs with predominant wave length within radiation spectrum 625-630 nanometers have light flux which is 2-3- times more intense than in LEDs with wave length equal to 640-645 nanometers but their coloration coordinates are not within the existing standardized coloration range (Figure 4) [4]. Manufactures of red LEDs together with experts from the photometric laboratory of the labor protection department at All-Russian Research Institute of Railway Hygiene thought it necessary to examine possibilities how to extend boundaries of red signals coloration area for railway traffic lights. The examination was to be in a form of an experiment during which probability of perceiving a red signal with coloration coordinates corresponding to red LEDs with predominant wave length equal to 625630 nanometers was assessed under real life conditions of traffic lights operation.
In the course of the experiment responses given by an observer concerning a signal color were put into the $\log$ in column, where figure "1" meant yellow color, and figure "2" meant red color [4]. Time of color sense in seconds was fixed in another column. The consequence of the given series of signals was put into the third column where figure "1" meant yellow color with coloration coordinates $x_{1}=0.612, y_{1}$ $=0.385$; figure " 2 " meant red light with coordinates $x_{2}=0.703, y_{2}=0.297$; figure " 3 " meant red light with coordinates $x_{3}=0.713, y_{3}$ $=0.287$ (table 4).

If we analyze the given data we can see that if a red light wave length is close to 650 nanometers than probability of correct color sense increases and response time to red light goes down. It is important when we determine a stopping distance length for a vehicle under various weather conditions. Light and color thresholds are determined in light technique for a small-sized light source (figure 5). 


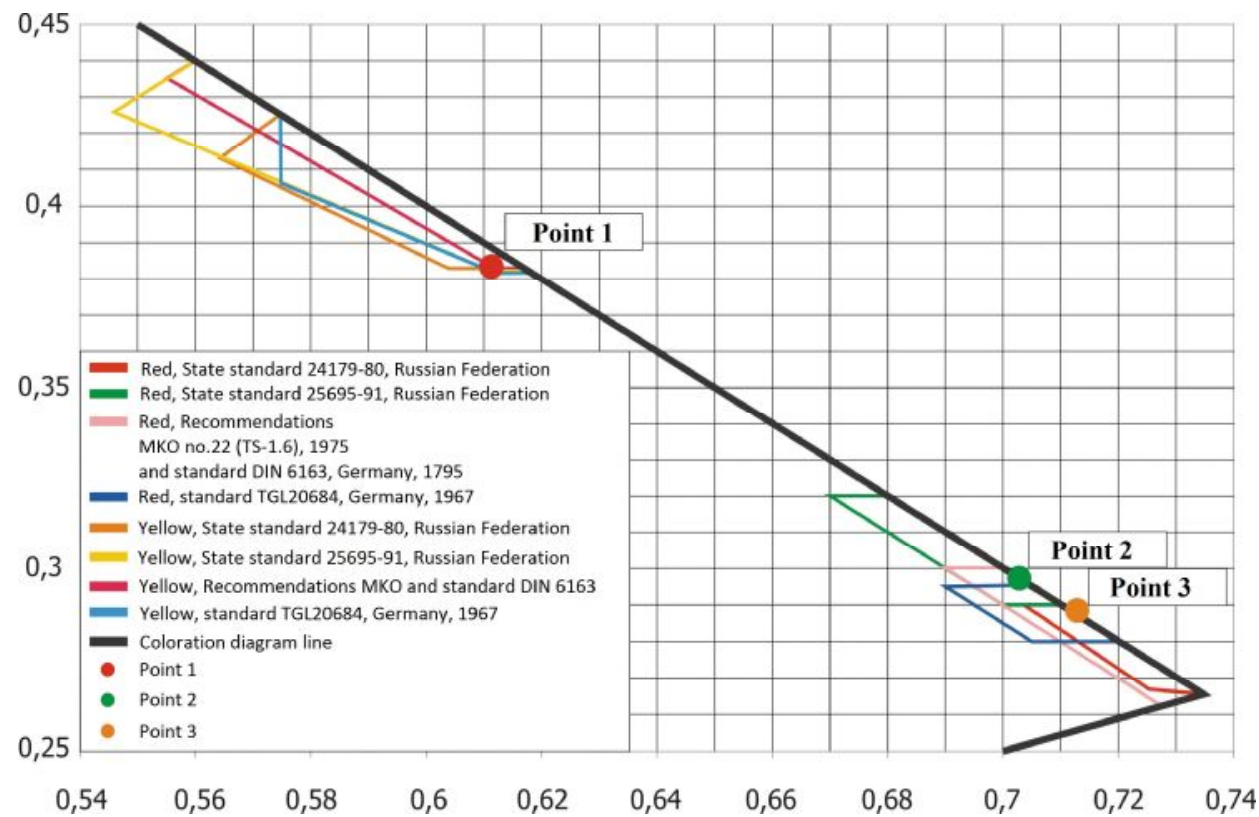

Figure 4. Coloration coordinates with signal color areas as per standards accepted in various countries

Table 4

Experimental results on light signals determination

\begin{tabular}{|l|c|c|c|c|c|c|}
\hline \multicolumn{1}{|c|}{ Background; brightness, cd/m2 } & \multicolumn{3}{c|}{ Sky, $5060 \div 17700$} & \multicolumn{3}{c|}{ Green, $107 \div 640$} \\
\hline \multicolumn{1}{|c|}{ Number of examined coloration point } & $\ll 1 »$ & $\ll 2 »$ & $\ll 3 »$ & $\ll 1 »$ & $\ll 2 »$ & $\ll 3 »$ \\
\hline Number of presentations $(n)$, quantity & 867 & 866 & 867 & 205 & 208 & 207 \\
\hline Number of mistakes in color determination, quantity & 3 & $\mathbf{3}$ & 2 & 0 & 0 & 0 \\
\hline Probability of correct color determination $(P)$ & 0,9965 & 0,9966 & 0,9977 & 1,0 & 1,0 & 1,0 \\
\hline Average determination time $\left(\tau_{\mathrm{cp}}\right), \mathrm{s}$ & 1,030 & 1,005 & 0,996 & 0,814 & 0,731 & 0,715 \\
\hline Quadratic mean error assessment $(s), \mathrm{s}$ & 0,237 & 0,251 & 0,242 & 0,199 & 0,167 & 0,124 \\
\hline
\end{tabular}

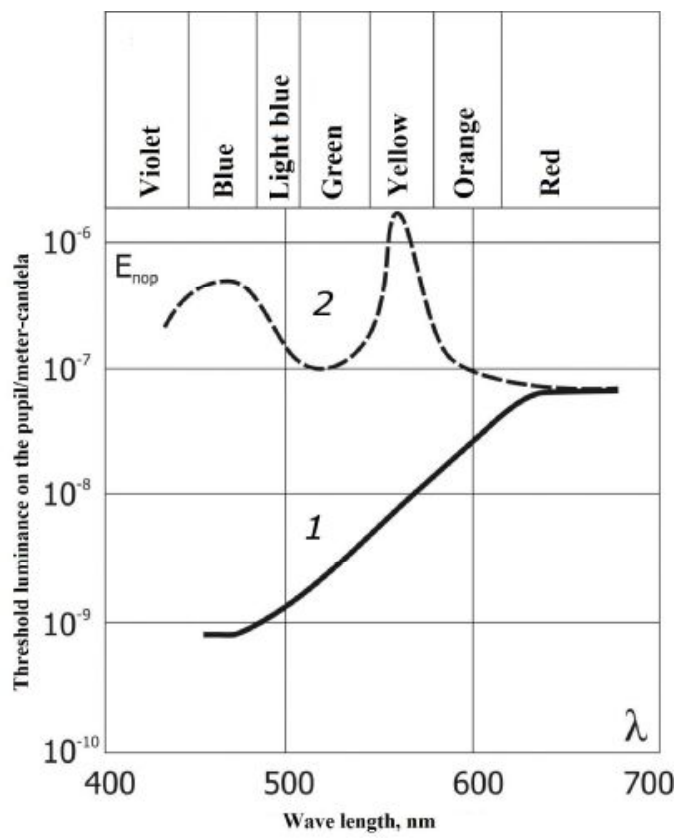

Figure 5. Light (1) and color (2) threshold for a small-sized light source 
We can see from the data on light and color threshold ratio that a man simultaneously sees light and determines its color starting from wave length equal to 650 and under certain luminance. It is hard to explain this fact on the basis of planar Jung-Helmholtz hypothesis [6], but it is clearly explained if we apply fiber-optical approach to "Mueller cell cone" system functioning.

In 2007 researchers led by Kristian Franze, a scientist employed at Cambridge University, revealed that one type of retina glia well-known as Mueller cells functioned as optical fibers when directing light to photoreceptors. But still there was no answer to a question: how come that those natural optical fibers supported two types of photoreceptors: rods which operated under weak lighting, and cones which helped people to see in bright daylight.

Those cells were first described by Heinrich Mueller, a German anatomist (18201864). They have a peculiarity, namely, they are located from the inner limiting membrane (which is adjacent to the vitreous humor) up to the outer limiting membrane. Cells bodies are located in the inner granular layer. Mueller cells architectonic loss matters a lot when retina layer separation occurs. Results of research accomplished in Leipzig University in 2007 showed that Mueller cells had optical function. They collect light from the retina anterior surface and conduct it to photoreceptors located on its posterior surface just like a fiber-optical cable. if not for Mueller cells, light would get to photoreceptors being diffused and it could result in lower visual acuity. Researchers both from Leipzig and Gottingen Universities in Germany and Universidade Central De Caribe Bayamon, Puerto-Rico, and Cambridge University in Great Britain detected how light was directed at Mueller cells (Figure 6). Having done that, they corrected a conventional visual analyzer system. Mueller cells operate as optical fibers, they direct and concentrate yellow-green light spectrum which many cones are maximum sensitive to. Blue light leaks from Mueller cells to activate rods.

Yellow spot cuts out waves with length equal to $450-460 \mathrm{~nm}$ from the whole blue spectrum. Mueller cells contain a focon for collect- ing and receiving diffused light from a point in space changing light refraction index as per their length (Figure 7).

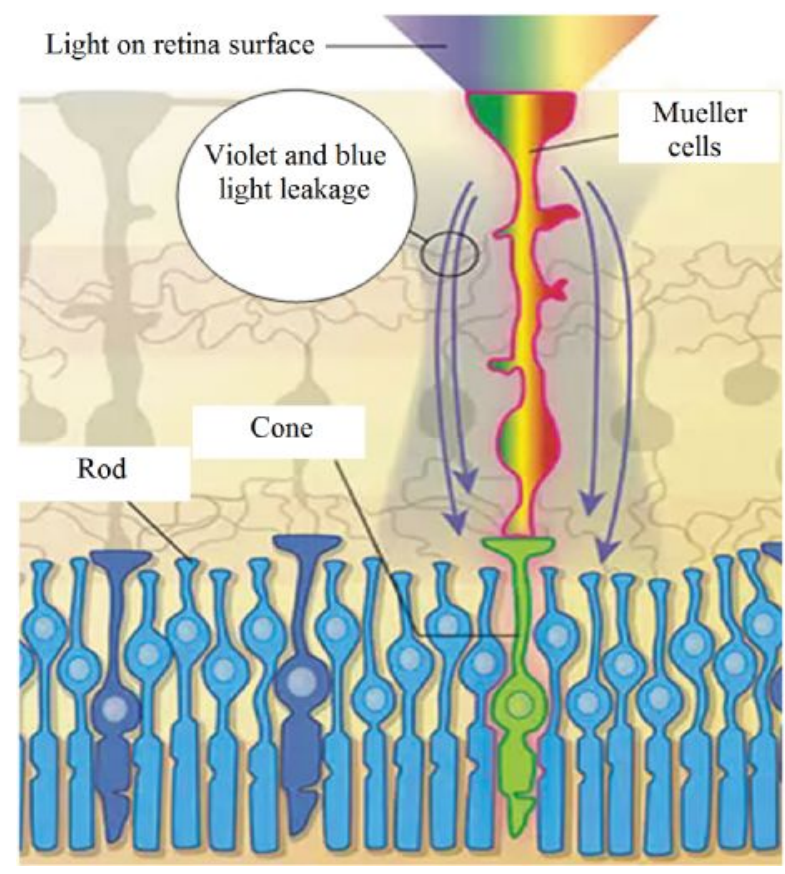

Figure 6. Optical Mueller cells and leakage of violet and blue light

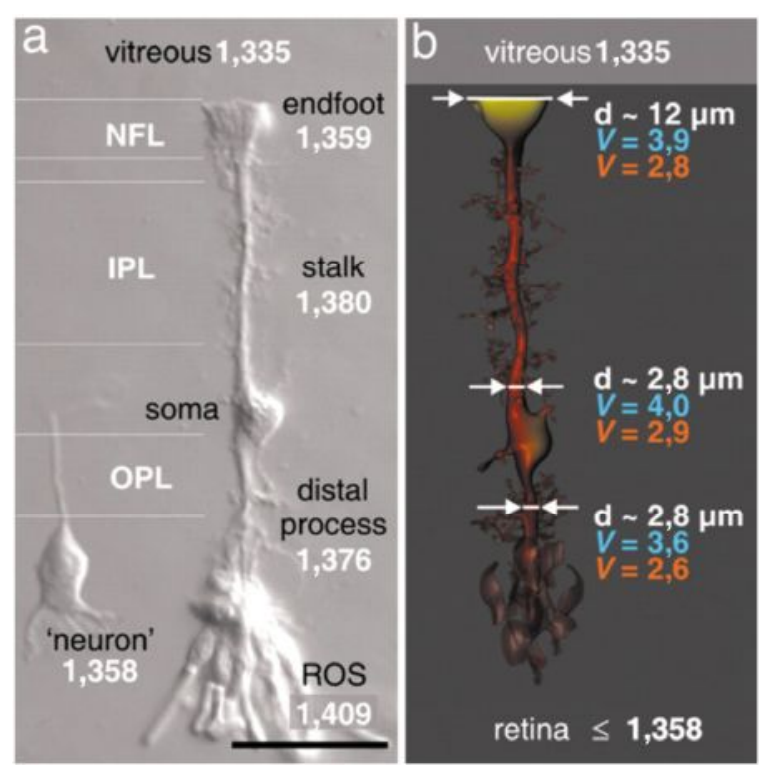

Figure 7. General outlook of Mueller cell and distribution of refraction index values as per its length [12]

Scientists from Israel Technological Institute in Haifa detected that Mueller cells operated as optical fiber [13].

Here Mueller cells lit by white light propagate wave lengths in green-red area for two cones types, and blue-violet light gets through 
retina to activate rods. Maximum light concentration in Mueller cells is observed in yellowgreen area of light spectrum at wave length being equal to $560 \mathrm{~nm}$ [13].

University researchers led by Amichai Labin examined increased retina of a cavy applying confocal microscopy and detected that each Mueller cell combined with an individual cone, and almost $90 \%$ of all the cones were linked to those cells. Optical fiber effect could increase a number of photons reaching one cone almost 11 times.

There are a lot of works dedicated to cones and rods but none of them has detailed an optical scheme describing how light gets on photosensitive opsins and how it penetrates into pigment epithelium cells bodies. There are hypotheses on operational principles for rods and cones, and external parts of their membranes which can be considered as physical analogues of a wave guide with a conical and cylinder form in the eye transparent body medium (liquid medium) [10, 11]. It gives an opportunity to review traditional ideas on visual process. According to Medeiros, an external section of a cone membrane can function as a cone wave guide [11]. Wide cone section meets entering rays which are perceived by the membrane acting as a cone wave guide in the liquid medium of the eye transparent body (the eye liquid medium). The order of rays focusing in this medium is opposite to the order of rays focusing in the air optical system (they focus as per chromatic aberration depending on a wave length). Their focusing before entering the membrane and entering it are opposite and it is regulated by specific functioning of the membrane cone form; it operates as a cone wave guide in the cone structure where walls have various reflecting capacity and various refraction indices which fixes the order which rays enter in: reds $\rightarrow$ green $\rightarrow$ blue (for color sight trichromatism system), for example, in primates and people (Figure 8).

The work gives the results of modeling light spectrum distribution as per optical cone length and optically transparent cone walls. Mueller cells spectral features correlate well with the eye visibility curve (Figure 9, 10) [11]. Research in this field still continues.

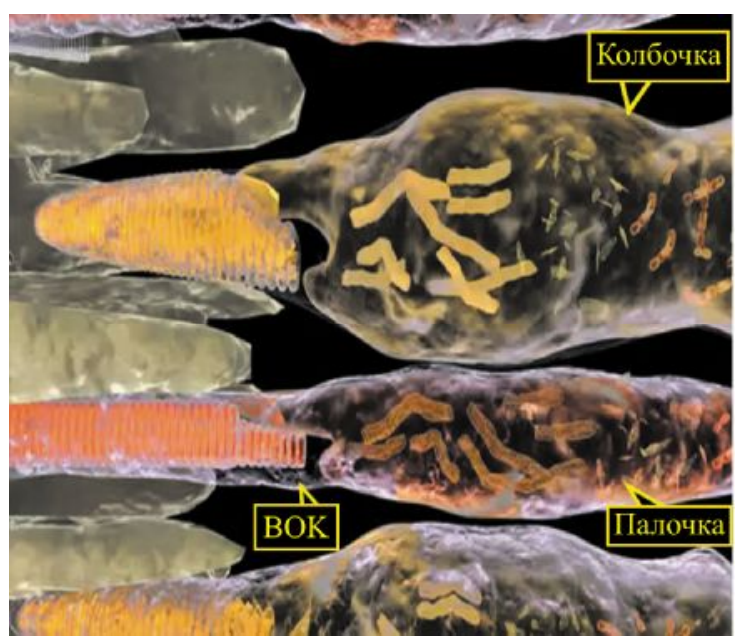

Figure 8. Rods and cones structure with fiber-optical wedge detection (FOW) [7]

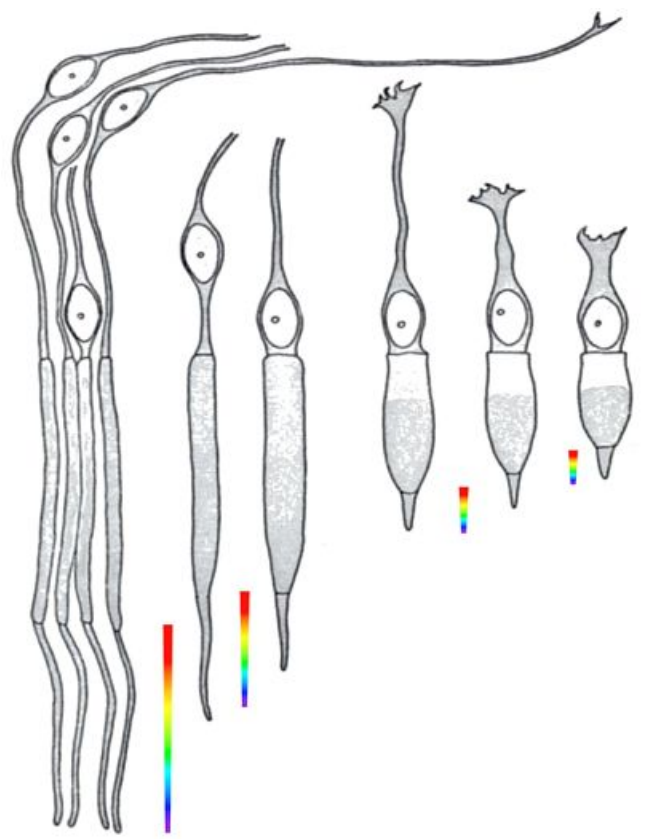

Figure 9. Forms of light spectrum passing through retina

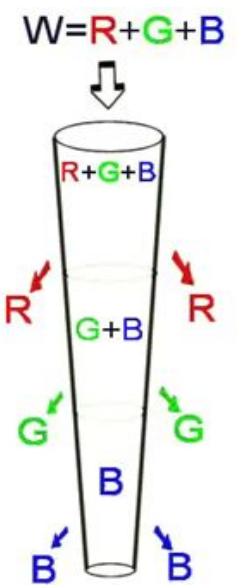

Figure 10. Cone fiber operation as wave guide for light spectrum rays 
This approach clearly shows how light gets into exterior segments of rods and cones and into pigment epithelium cells bodies; the model as well enables assessing color determination for various signals, notably, as per determination delay time.

Assessment of time delays in light perception matters a lot for car drivers and locomotive drivers.

There are experimental results for time delays (in milliseconds) which can be derived for any wave length, $\lambda$ (in millimicrons), concerning perceptual delay of $650 \mathrm{~nm}$ red light, which cam approximately look like:

$$
T_{\text {delay }}(\mathrm{msec})=97.5-0.15 \lambda(\mathrm{nm}) .
$$

It gives zero delay (msec) for $650 \mathrm{~nm}$ red light and it can give up to $30 \mathrm{msec}$ delay for the shortest light wave. The data show that there is time dispersion (delay) between blue and red light. For example, light-blue light $(450 \mathrm{~nm})$ is perceived with an approximately 30 -sec delay in comparison with red light $(650$ $\mathrm{nm})$.

Systematizing the knowledge on color determination as per 3D "Mueller cell - cone" system helps to clarify existing knowledge on planar Jung-Helmholtz 3-color hypothesis concerning spectral decomposition of white light and time delays in perception of red, green, and blue light. It has great applied significance in providing traffic safety and reducing negative influence exerted by the environment on human health.

Relevant administrative actions are taken when drivers pass in spite of red signals; unfortunately, there are no such actions related to providing $100 \%$ red signal determination allowing for the human eye structure.

For example, reasons for passing under red signals on railroads are detailed in "Instruction for a locomotive team concerning prevention of passing traffic lights with inhibiting signals" which was approved on January 11, 2011.
When movement speed increases from 40 $\mathrm{km} / \mathrm{h}$ to $80 \mathrm{~km} / \mathrm{h}$, a driver reaction time almost doubles; we should remember that many of them drive locomotives at a speed equal to 100 $\mathrm{km} / \mathrm{h}$ or faster and are constantly under stress.

At night reaction time almost doubles in comparison with average daily one. Besides, alcohol aftereffects make for its 1.3 times increase; working conditions of a locomotive driver provide for almost the same increase.

Medical observations conducted for more than a hundred years prove that smoking has an adverse effect on eyesight. Effects exerted by toxic substances contained in tobacco smoke often lead to tobacco amblyopia in chain smokers which contributes to weaker perception of red color, lower visual acuity, and spots occurrence in the visual field. All these things are unacceptable for a locomotive driver as per traffic safety provision.

We do not consider mechanism of flash blinding due to changes in Mueller cells optical geometry under excessive dose of light (red and blue) in this paper, though it is wellknown that blinding makes reaction time 2 and even more times longer. The issue will be dealt with later.

\section{Conclusion:}

1. Under LED lighting risks of inadequate color determination are high and it makes negative consequences for vehicles drivers much more probable.

2. Fiber-optical approach to cones functioning clearly explains why red color signal $(650 \mathrm{~nm})$ is determined simultaneously with light sense.

3. Traffic lights for transport systems are to be designed allowing for physiology of light perception by the human visual analyzer. Application of LEDs with wave length shorter than 650 nm should be absolutely excluded.

\section{References}

1. Bakutkin V.V., Kirichuk V.F., Kuznetsova E.V. Vliyanie dinamicheskoi elektroneirostimulyatsii na akkomodatsionnye sposobnosti glaza cheloveka [Influence exerted by dynamic electric neurostimulaiton on accommodation abilities of a human eye]. Problemy opticheskoi fiziki i biofotoniki: materialy XIII Mezhdunar. molodezhnoi nauchnoi shkoly po optike, lazernoi fizike i biofotonike [Issues of optical phys- 
ics and biophotonics: materials of the XIII International youth scientific schools on optics, laser physics and biophotonics]. Saratov, Novyi veter Publ., 2009, 219 p. (in Russian).

2. Berman S.M., Klier R.D. Nedavno otkrytyi fotoretseptor cheloveka i predydushchie issledovaniya $\mathrm{v}$ oblasti zreniya [Recently discovered human photoreceptor and previous research in the sphere of human sight]. Svetotekhnika, 2008, no. 3, pp. 49-53 (in Russian).

3. Deinego V.N., Ivanov V.F. Raduga cvetov izoljacii provodov v svete svetodiodnogo osveshhenija [Rainbow of wire insulation colors under LED lighting]. KABEL-news, 2013, no. 2. Available at: http: //www.ruscable.ru/article/Raduga_cvetov_izolyacii_provodov_v_svete_svetodiodnogo_osveshheniya (18.06.2016) (in Russian).

4. Agafonov D.R., Murashova M.A., Nikiforov S.G., Pinchuk O.P., Stoljarevskaja R.I. Issledovanija vizual'nogo vosprijatija krasnyh zheleznodorozhnyh svetoforov na osnove svetoizluchajushhih diodov [Research on visual perception of red railway traffic lights based on LEDs]. Svetotehnika, 2003. Available at: www.led-e.ru/assets/files/pdf/Svetodiod-svetofor.pdf (22.09.2016) (in Russian).

5. Klinicheskaya anatomiya organa zreniya: chasti tsiliarnogo tela [Clinical anatomy of a sight organ: ciliary body parts]. StudFiles: failovyi arkhiv studentov. Available at: http: //www.studfiles.ru/preview/2243441/page: 7/ (15.10.2016) (in Russian).

6. Teoriya Yung-Gel'mgol'tsa [Jung-Helmholtz theory]. Spravochnik khimika 21: khimiya $i$ khimicheskaya tekhnologiya. Available at: http: //chem21.info/info/279269/ (03.07.2016) (in Russian).

7. $3 \mathrm{~d}$ rods cones eye anatomy with bipolar pigmented amacrine horizontal cells epithelium optic nerve and cell nucleus body human medical. TurboSquid. Available at: http: //www.turbosquid.com/3dmodels/max-rods-cones-eye-anatomy/570819 (08.10.2016)

8. Flannagan M.J., Blower D.F., Devonshire J.M. Effects of Warning Lamp Color and Intensity on Driver Vision: Report of work on Non-Blinding Emergency Vehicle Lighting (NBEVL). Michigan, 2008, 54 p.

9. Franze K., Grosche J., Skatchkov S.N., Schinkinger S., Ch. Foja, D.Schild, O.Uckermann, K.Travis, A.Reichenbach, J.Guck.Müller cells are living optical fibers in the vertebrate retina. PNAS, 2007, vol. 104, no. 20, pp. 8287-8292. DOI: 10.1073/pnas.0611180104.

10. Huth G.C. A Modern Explanation for Light Interaction with the Retina of the Eye Based on Nanostructural Geometry: Rethinking the Vision Process. Available at: http: //www.ghuth.com/ (21.07.2016).

11. Labin A.M., Safuri Sh.K., Ribak E.N., Perlman I. Müller cells separate between wavelengths to improve day vision with minimal effect upon night vision. Nature Communications, 2014, no. 4319. DOI: $10.1038 /$ ncomms5319

12. Luoma Ju., Flannagan M.J., Sivak M., Aoki M., Traube E.C. Effects of turn-signal color on reaction times to brake signals. Michigan, 1995, $19 \mathrm{p}$.

13. Medeiros J.A. The Cone Spectrometer Model (CSM). Color Vision: A New Understanding. Available at: http: //conesandcolor.net/_F_CSM.htm (22.10.2016)

14. Navarro R., Santamaría J., Bescós J. Accommodation-dependent model of the human eye with aspherics. Journal of the Optical Society of America A, 1985, vol. 2, no. 8, pp. 1273-1280. DOI: 10.1364/JOSAA.2.001273.

15. Plainis S., Ginis H.S., Pallikaris A. The effect of ocular aberrations on steady-state errors of accommodative response. J.Vis, 2005, vol. 5, no. 7, pp. 466-477.

16. Tarrant J., Roorda A., Wildsoet C.F. Determining the accommodative response from wavefront aberrations. Journal of Vision, 2010, vol. 10, no 5, pp. 4.

Kaptsov V.A., Deinego V.N. Health risks occurring when color is percepted under led lighting. Health Risk Analysis, 2017, no. 2, pp.16-24. DOI: 10.21668/health.risk/2017.2.02.eng

Received: 10.03 .2017

Accepted: 16.05 .2017

Published: 30.06 .2017 


\title{
SCIENTIFIC AND METHODOLOGICAL APPROACHES TO RISK ANALYSIS IN HYGIENE AND EPIDEMIOLOGY
}

UDC 614.7/9+658.562(072)

DOI: $10.21668 /$ health.risk/2017.2.03.eng

\section{METHODOLOGICAL APPROACHES AND PRACTICES FOR ASSESSING CONSUMERS' HEALTH RISKS CAUSED BY DURABLE GOODS (ON THE EXAMPLE OF CONSTRUCTION AND FINISHING MATERIALS)}

\author{
I.V. May ${ }^{1}$, N.V. Nikiforova ${ }^{1}$, V.A. Khoroshavin ${ }^{2}$ \\ ${ }^{1}$ Federal Scientific Center for Medical and Preventive Health Risk Management Technologies, 82 Monastyrskaya \\ Str., Perm, 614045, Russian Federation \\ ${ }^{2}$ Center for Hygiene and Epidemiology in Perm region, 50 Kuibyisheva Str., Perm, 614000, Russian Federation
}

The article deals with an issue related to risk assessment as a criterion of durable consumer goods safety for population health; construction materials and finishing materials are a very relevant example of such goods. We showed that legislative and methodological grounds for assessing such risks were not sufficient. So we developed approaches to risk assessment on the basis of evolution models which allowed to examine risks growth under chronic exposure. We revealed that even if certain goods conformed to sanitary standards set forth by technical regulations they could still cause unacceptable health risks for consumers. And the risks tended to grow dramatically when several goods with similar or identical hazardous effects were consumed together.

We performed epidemiologic and profound medical-biological examinations and obtained authentic mathematical dependencies of correlation between exposure and consumer health disorders; these models are adequate to the data taken from relevant scientific literature. We tested methodological approaches to application of the detected "dose - effect" dependencies for evolution modeling. These approaches were tried out in real-life situations when certain construction and finishing materials were used in precast frame low-rise housing construction. We proved that long living in houses which were built with the use of 7-8 and more polymer-containing materials formed unacceptable risks for citizens' health after 10-12 years. The results we obtained helped to justify a decision that people should moved houses as it was unacceptable to live in them any longer; it was also considered inadvisable to use newly-built and still uninhabited houses of the studied lines for constant living.

Basically, these methodical approaches can be applied in assessing risks caused by a wide range of durable consumer goods.

Key words: durable consumer goods, health risks, risks evolution, technical regulation, chronic exposure, polymer-containing materials.

Durable consumer products are the products with a long service life to failure, which takes three years or longer ${ }^{1}$. Purchase of a du- rable product requires long-term constant or systematic contact of a person with the goods, and consequently - with dangers and threats

(C) May I.V., Nikiforova N.V., Khoroshavin V.A., 2017

Irina V. May - Doctor of Biological Sciences, Professor, Deputy Director for Research (e-mail: may@fcrisk.ru; tel.: +7 (342) 237-25-47).

Nadezhda V. Nikiforova - research worker (e-mail: kriulina@fcrisk.ru; tel. +7 (342) 237-18-04).

Viktor A. Khoroshavin - Doctor of Medicine Sciences, Head Physician (e-mail: cgepo@ mail.ru; tel.: +7(342) 239-34-09).

${ }^{1}$ On approval of the list of durable consumer goods, including components (parts, assemblies, units), which after a certain time-period may pose danger to life and health of a consumer, cause damage to his property or environment, and manufacturer is obliged to establish service-life period in relation thereto, and the list of goods, which, upon expiration, are considered nonsuitable for intended use (with amendments and additions): Resolution of RF Government No. 720 of June, 16, 1997. [esource]. - URL: http://pravo.gov.ru/proxy/ips/?docbody=\&nd=102047733 (12.03.2017). 
that are the inherent properties of the product (if any). The specified resolution of the government legislatively set forth the list of durable goods, which are potential sources of danger. This is the document of a definite focus to oblige manufacturers to set a time-period upon the expiry thereof the product loses its consumer properties, and can pose threat to life, health of a consumer, cause damage to his property or environment. It is assumed that the product is safe before the specified time limit. Construction and finishing materials are not subject to this regulation, as they do not have a limited period of safety. However, undoubtedly, by definition, materials used in construction and interior decoration of premises, including residential ones, belong to durable goods.

The system of technical regulation in Russia (as well as in the Eurasian Economic Union, as a whole) defines "safety as the absence of unacceptable risk associated with the possibility of causing harm and (or) causing damage" $^{\prime 2}$. During the entire useful life, products should not form an unacceptable risk to health of a consumer. At the same time, "risk" is considered as the "combination of the probability to cause harm and the consequences of this harm to human life or health, property, environment, life or health of animals and plants".

However, the methodology for assessing risk of non-food consumer products, especially of a long-term use, is being developed only recently [12], and has an extremely poor application practice. In Russian Federation, this situation is conditioned by several reasons.

First, in a number of technical regulations, the definition of safety does not fully comply with the above definition, which eliminates the need for a full-fledged risk assessment procedure. Thus, for example, TR TS "On the safety of furniture"3 defines "...chemical safety as a state of a piece of furniture, in which there is no unacceptable risk associated with causing harm to life and health of a consumer due to exceeded concentration level 4 of harmful chemicals in the premises air" (Article 3). As it follows from the definition, an unacceptable risk to health is absent provided the observance of the standards established by the regulations. The same or similar definitions are contained in the technical regulations "On the safety of products intended for children and adolescents"5, TR TS "On the safety of light industry products" 6 and some others. For instance: "Biological safety is the absence of unacceptable health risk due to noncompliance of biological, toxicological, physical and physicochemical properties with the established requirements". Thus, the conclusions on products safety can be made based on comparative assessment of the products parameters with the established standards. It is specified that, if the excreted impurities that

\footnotetext{
${ }^{2}$ Agreement on implementation of a coordinated policy in the field of technical regulation, sanitary and phytosanitary measures: Agreement of the Governments of the Eurasian Economic Community member states of January 25, 2008 (as amended on 19.05.2011, with amendments ddt. 10.10.2014) [e-source]. - URL: http://www.consultant.ru/document/cons_doc_LAW_135270/ (10.03.2017).

${ }^{3}$ On the safety of furniture products: Technical Regulations of the Customs Union [e-source]/approved by the resolution of the Eurasian Economic Committee Council No. 32 ddt. 15.07.2012 - URL: http://www.tsouz.ru/KTS/KTS31/Pages/R 32.aspx (01.04.2017).

${ }^{4}$ This refers to the "maximum permissible concentration".

${ }^{5}$ On the safety of products intended for children and adolescents: Technical Regulations of the Customs Union 007/2011 2012 [e-source] /approved by the resolution of the Customs Union Commission No. 797 ddt. September, 23, 2011 - URL: http://www.tsouz.ru/KTS/KTS31/Pages/R 797.aspx (01.04.2017).

${ }^{6}$ On the safety of light industry products: Technical Regulations of the Customs Union [e-source]/ approved by the resolution of the Eurasian Economic Committee Council No. 876 ddt. 09.12.2011 - URL: http://www.tsouz.ru/KTS/KTS31/Pages/R 876.aspx (01.04.2017).

${ }^{7}$ GN 2.1.6.1338-03. Maximum permissible concentration of pollutants in the atmospheric air of populated areas: Hygienic Standards (with amendments and additions) [e-source]. - URL: http://www.gosthelp.ru/text/GN216133803Predelnodopust.html (12.03.2017).
} 
have a summation effect are present, this summation must be taken into account. However, the current normative document Hygienic Standards 2.1.6.1338-037 gives a closed list of summation groups. The application of this document, for example, in assessing furniture safety (Annex 2 to the TR TS, the list of excreted standardized chemical impurities is given) makes it possible to take into account only the summation of ammonia and formaldehyde action (group 6005). When assessing the risk of the same materials for the health of a consumer, simultaneous effects on critical organs and systems could be taken into account for a much wider range of impurities [15].

Secondly, the legislation in the sphere of technical regulation is extremely weak in regulating the aspects of assessing goods safety at a long-term, or systematic products using. It is assumed that applying $\mathrm{MPC}_{\text {daily average }}$ as a safety criterion guarantees safety, i.e. absence of risks in case of chronic exposure. At the same time, the established safety standards specified in the regulations of the Customs Union mainly exclude the procedures for assessing health risks. Justification of the risk-based safety standards is the most promising direction for improving technical regulation system $[2,3$, $13,14,16]$.

In addition, Federal Law No. $184-\mathrm{FZ}^{8}$ contains a provision (clause 7, Article 7), which states that "...technical regulations cannot contain requirements for products that cause harm to life or health of citizens, accumulated with the long-term use of this products ... and depending on other factors that do not allow to determine the acceptable risk level. In these cases, the technical regulations may contain a requirement to inform the acquirer of the possible harm, and the factors it depends thereon".

Thus, a manufacturer shall not be held liable for any negative health consequences that can arise either as a result of long-term continuous use of the same products of short-term, one-time use (food, cosmetic, household chemicals), or as a result of using durable products (furniture, construction and finishing materials, etc.).

It should be noted that this provision does not coincide with a number of principal provisions adopted in global legislation. Thus, the European Union General Product Safety Directive 2001/95/EC ${ }^{9}$ admits that products conformity to the criteria, intended to guarantee general safety, does not prevent the possibility for taking the appropriate measures in limiting product release, withdraw or recall from the market, if, despite the specified conformity, this product turns to be dangerous (see Article 3, paragraph 5). Consequently, a situation is admitted where, in observance of all requirements and standards, under real-life conditions, the products can turn to be dangerous for life and health of a consumer.

Third, the risk assessment for non-food products is poorly demanded by the consumers themselves, primarily because of low awareness of the risks. So, for example, according to a number of researchers [9], buyers of construction materials pay attention to the goods production technology in $13 \%$ of cases only, but focus more on the price and appearance of a product (more than $70 \%$ of respondents). At the same time, informing about the main risk factors and the related health consequences is necessary to develop adequate management decisions to ensure sanitary and epidemiological well-being of the population $[4,6,8]$.

In addition to toys, perfumes and cosmetics, goods for children and adolescents, researchers most often pay attention to the need to assess and minimize risks to human health when using polymer-containing construction materials and furniture [1, 5, 17, 18, 20-24]. With respect to the latter, the time factor is quite critical, since these are durable goods.

8 On technical regulation: Federal Law No. 184-FZ of December 27, 2002 [e-source]. - URL: http://www.consultant.ru/document/consdocLAW 40241/Access date: 01.03.2017/ (12.03.2017).

${ }^{9}$ Directive 2001/95/EC of the European Parliament and Council of 3 December, 2001 on the general safety of products [e-source] - URL: www.icqc.eu/userfiles/File/directiva\%202001\%2095\%20ec\%20gpsd\%20ru.pdf (01.03.2017). 
The foregoing determined the purpose of the study - the rationale for methodological approaches to assessing the risk of exposure to a number of durable goods to human health and testing these approaches in practice to make management decisions on minimizing risks.

As the objects of research, we selected polymer-containing construction materials, used in real-life conditions of precast frame low-rise housing construction, the health of the population living in precast frame houses and brick houses, the air quality in the premises of precast frame houses.

Materials and methods. The health risk assessment was carried out in accordance with the generally accepted stage-by-stage procedure $[4,12]$, supplementing each stage with indepth studies.

The construction materials hazard was identified according to the technical documentation data for the products, and the results of chamber tests in samples of 18 types of construction materials. The materials chamber research was conducted in accordance with the approved methodology MU 2.1.2.1829-04 "Sanitary and hygienic assessment for polymeric and polymer-containing construction materials and structures intended for use in residential and public housing construction". The chamber impregnation with a construction material corresponded to the real-life average impregnation of the living accommodation with this material. A total of 71 samples of goods were examined for the migration of formaldehyde, ammonia, dioctyl phthalate, phenol, diphosphopentoxide, acrylonitrile, dibutyl phthalate, sulfur dioxide and styrene. Chemical impurities quantitative and qualitative analysis was carried out using the generally recognized methods: RD 52.04.186-89, MUK 4.1.598-96, MP 01.022-07, MUK 4.1.1478-03, MUK 4.1.1045-01. Residents exposure to the impurities excreted from the construction materials was estimated by calculations (based on the results of chamber tests, and technical documentation for construction), and by the results of the direct instrumental measurements of indoor air quality. In total,
852 air samples of 152 rooms were selected and analyzed. Based on the questionnaire survey findings, the average duration of stay of different age people was taken into account in the conditions of exposure to the indoor air.

The construction and parameterization of the dose-effect models were performed according to the epidemiological and in-depth medical and biological research, taking into account the relevant literature data on the proven effects of excreted impurities on human health. The resulting paired dependencies were adapted to the evolutionary model of the accumulation of risk to the health of products (goods) consumers. As a computational form of the evolutionary model, a system of recurrence relations recorded for each type of response (health disorder) was adopted in a general form $[7,10,11]$ :

$$
R_{t+1}^{i}=R_{t}^{i}+\left(\alpha_{i} R_{t}^{i}+\sum_{j} \Delta R_{t}^{i j}\right) C
$$

where $R_{t+1}^{i}$ is health disorders risk from $i$-th response, at a time $t+1 ; R_{t}^{i}$ is health disorders risk from $i$-th response, at a time $t ; \alpha_{i}$ is the coefficient that takes into account the evolution of risk due to natural causes.

The study design for the formulation of dependencies included the exposure assessment for the group of observations (the population living in precast frame houses) and the personalized health status assessment based on the findings of the directed biomedical research performed by the experts of the FBSI "Federal Scientific Center for Medical and Preventive Health Risk Management Technologies" (license for medical activities No. FS-59-01-001197). At the final stage of the study, we established and parameterized dependences between the concentrations (as indicators of the population exposure), and the responses in the form of health disorders in the population living in the precast frame houses. To confirm the dependencies obtained, the data of the in-depth health survey of the population living in the precast frame 
houses were compared with the survey data of the reference group.

The observation group consisted of 93 people who were permanently living under conditions of a known exposure to chemical impurities excreted from the construction materials of the precast frame buildings (69 adults aged 18 to 83 , and 26 children aged 1 to 17). The structure of the observation group was completely determined by the actual living of people in the houses under study. The reference group (79 people), adequate in age and sex composition, was selected from the residents of other territories and houses, at the condition of the absent higher levels of chemical impurities in the air of their houses, excreted from the construction materials.

Examination of the somatic status in the population of the observation and reference groups was identical, and included an in-depth clinical examination by pediatrician, therapist, neurologist, gastroenterologist, allergistimmunologist, and oculist.

Clinical and functional studies were conducted according to traditional methods in compliance with the ethical principles set forth by the Helsinki Declaration (1975, with amendments of 1983) and the Russian Federation National Standard GOST-R 523792005 "Good Clinical Practice" (ICH E6 GCP).

Data processing was carried out with statistical methods (Statistica 6.0). To compare the groups and assess reliability, Student's and Fisher's criteria were used. Differences in the results were statistically significant at $p<0.05$. The dependencies between the signs were evaluated by single-factor variance and correlation-regression analysis.

Results and discussion. Based on the review of documentation submitted by the developers of the precast frame houses, it was established that up to 9 types of polymercontaining materials were used in the construction of each precast frame house. The materials were directly in contact with the air of the residential housing (covering the walls, ceiling, floor, etc.) or with the air of the rooms through technical openings (for example, insulation materials).

The results of chamber studies showed that the materials excreted such chemical impurities as formaldehyde (in $29.6 \%$ cases, or 21 samples out of 71$)$, xylene $(77.8 \%$ cases, or 7 samples out of 9), methanol (in $1.4 \%$ cases, or 1 sample out of 71) into the air.

Samples of mineral wool $(0.0071 \pm$ $\left.0.0014 \mathrm{mg} / \mathrm{m}^{3}\right)$, noise insulation $(0.005 \pm$ $\left.0.0014 \mathrm{mg} / \mathrm{m}^{3}\right)$, expanded polystyrene $(0.003 \pm$ $\left.0.0014 \mathrm{mg} / \mathrm{m}^{3}\right)$, plywood $(0.0028 \pm 0.0006$ $\left.\mathrm{mg} / \mathrm{m}^{3}\right)$, gypsum-fiber sheet $(0.0027 \pm 0.0005$ $\mathrm{mg} / \mathrm{m}^{3}$ ) formed the highest concentrations of formaldehyde in the climate chambers air. The excretion of other chemical impurities into the air inside the chambers from the materials samples was at the levels below the determination thresholds of chemical analytical methods.

The chamber studies results for the construction and finishing materials, and the degree of their impregnation in residential premises showed that for almost all of the precast frame houses built within different projects, violations of hygienic standards, in terms of formaldehyde content, were likely expectable. The latter is determined by the migration of impurities to the environment at the combined use of materials, even taking into account the unprotected surfaces shielding. The average calculated concentrations inside the premises, owing to construction and finishing materials, made $0.018 \pm 0.008 \mathrm{mg} / \mathrm{m}^{3}$; with the values ranged from 0.011 to $0.025 \mathrm{mg} / \mathrm{m}^{3}$.

The calculated data were satisfactorily correlated with the results of instrumental measurements for the air quality inside the living spaces. The average measured concentration of formaldehyde in the residential space air was $0.0154 \pm 0.008 \mathrm{mg} / \mathrm{m}^{3}$. Moreover, during the cold period, the average daily concentrations for formaldehyde reached 0.083 $\mathrm{mg} / \mathrm{m}^{3}$ (8.3 $\left.\mathrm{MPC}_{\text {daily average }}\right)$; in summer days, when the air temperature was $30^{\circ} \mathrm{C}$ and more, the concentrations were recorded at 0.143 $\mathrm{mg} / \mathrm{m}^{3}$ (14.3 $\left.\mathrm{MPC}_{\text {daily average }}\right)$. The concentrations of other chemical impurities measured (benzene, toluene, ethylbenzene, xylene) did not exceed a tenth of the hygienic standards. 
The evidence that contamination is formed by the sources inside the room is enhanced by the measurements of chemical impurities in the air in the immediate vicinity of the residential buildings. The average daily level for formaldehyde in the atmospheric air did not exceed $0.001 \mathrm{mg} / \mathrm{m}^{3}$. As a consequence, further risk assessment of the products was carried out considering formaldehyde as the main hazard factor.

Reviewing the results of the health status' in-depth assessment for the population living in precast frame houses showed that the adult population had higher incidence rates relative to the reference group for respiratory diseases (1.7 times), skin and subcutaneous tissue (1.5 times).

Five logistic dependencies were obtained $\left(R^{2}=0.023-0.87, p<0.05\right)$, which describe an increase in the population morbidity level, as formaldehyde concentration in the air increases. These dependences were established for the classes of respiratory, skin and subcutaneous tissue diseases (Figure 1), and individual nosological forms of these classes: other allergic rhinitis (J30.3), other atopic dermatitis (L20.8), acute upper respiratory tract infection, unspecified (J06.9).

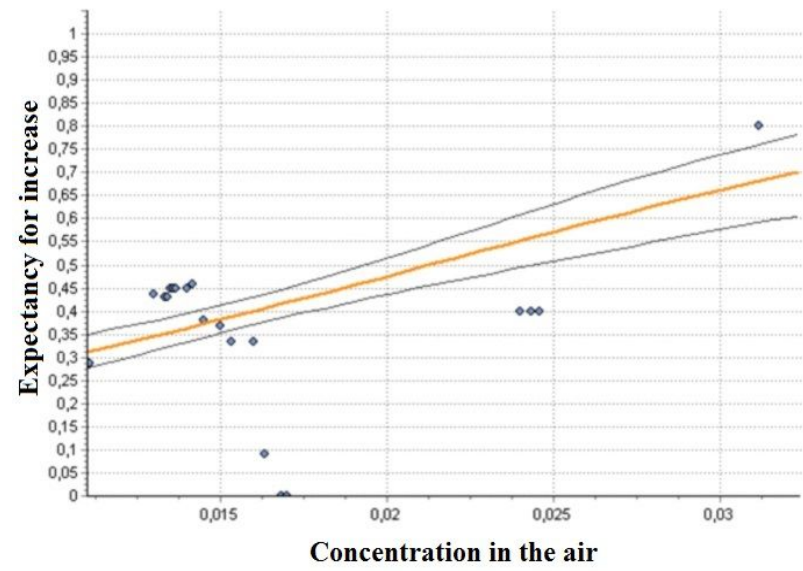

$a$
The results analysis of a comprehensive health status survey of the population in the observation group (as compared to the reference) showed that they have deviations in clinicallaboratory indicators, which may subsequently lead to the formation of morbidity corresponding to the models obtained.

Thus, it was established that formaldehyde content level in the blood of children' population living in precast frame houses was authentically higher than the reference level. Formaldehyde level in the blood of children was $0.0127 \pm 0.0014 \mathrm{mg} / \mathrm{dm}^{3}$ at a reference level of $0.0041 \pm 0.00041 \mathrm{mg} / \mathrm{dm}^{3}(p<0.05)$.

Nonspecific sensitization of human organism was established in the population of the observation group, as evidenced by the increased value of eosinophilic lymphocyte index by a factor of 1.3 in children in the observation group ( $0.09 \pm 0.02$ conventional units), compared with the children in the reference group $(0.074 \pm 0.0081$ conventional units $)(p=0.00)$. In adults of the observation group, this index made $0.1 \pm 0.013$ conv. units, and exceeded the index of the reference group by 1.4 times $(0.071 \pm 0.015$ conv. units $)(p=0.003)$.

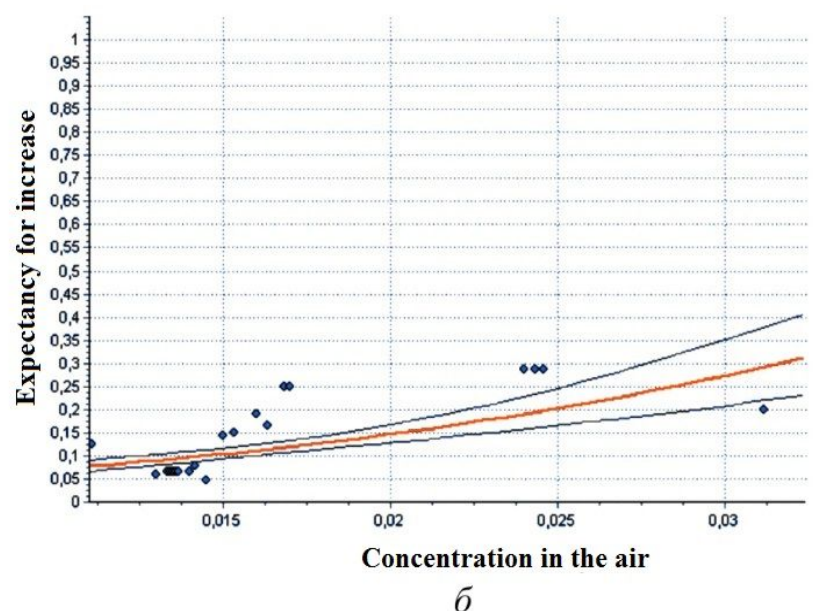

Fig. 1. Expectancy for an increasing morbidity: $a$ - respiratory diseases in the population living in precast frame houses at changes in formaldehyde concentration in the air, $y=\frac{1}{1+e^{-(-1,622+77,135 \times X)}},(p<0,05)$;

$b$ - for skin and subcutaneous tissue diseases class in the population of precast frame houses at changes in formaldehyde concentration in the air, $y=\frac{1}{1+e^{-(-3,334+81,152 \times X)}},(p<0,05)$ 
The higher level in relative number of eosinophils $(3.75 \pm 0.37 \%)$ was recorded in the adult observation group comparing to the reference $(2.16 \pm 0.38 \%)(p=0.0)$.

In general, $15-17 \%$ of the residents had early activation changes in the immune response to formaldehyde, consisting in the increased activation of interleukin-10 in functional samples. The children of the observation group had authentically higher IgE index specific to formaldehyde $\left(1.14 \pm 0.36 \mathrm{IU} / \mathrm{cm}^{3}\right.$ vs $\left.0.746 \pm 0.28 \mathrm{IU} / \mathrm{cm}^{3}, p=0.036\right)$.

The paired dependencies obtained and confirmed by the in-depth studies made it possible to construct a model for the evolution of an extra risk for respiratory functions impairment in the residents under the influence of formaldehyde. The general form of the dependence looked like this:

$$
\begin{gathered}
R_{t+1}=g\left(R_{t}+0,0245 R_{t}+0,00473 \times\right. \\
\left.\times\left\langle\frac{1}{1+e^{-(-1,622+77,135 X)}}-\frac{1}{1+e^{-(-1,622+77,135 K)}}\right\rangle\right)
\end{gathered}
$$

where

$R_{(t+1)}$ is the risk of respiratory system disorders at time $t+1$;

$g-$ severity of health disorders in respiratory system diseases;

$R_{t}-$ risk of respiratory system disorders at time $t$;

$X$ - average annual formaldehyde concentration in the indoor air, $\mathrm{mg} / \mathrm{m}^{3}$;

$K-$ is the inactive concentration of formaldehyde, $\mathrm{mg} / \mathrm{m}^{3}$.

The value recommended by the World Health Organization for upper respiratory tract diseases $(g=0.07)[19]$ was taken as the severity of a disorder, which allowed to further apply standard risk profile criteria [15].

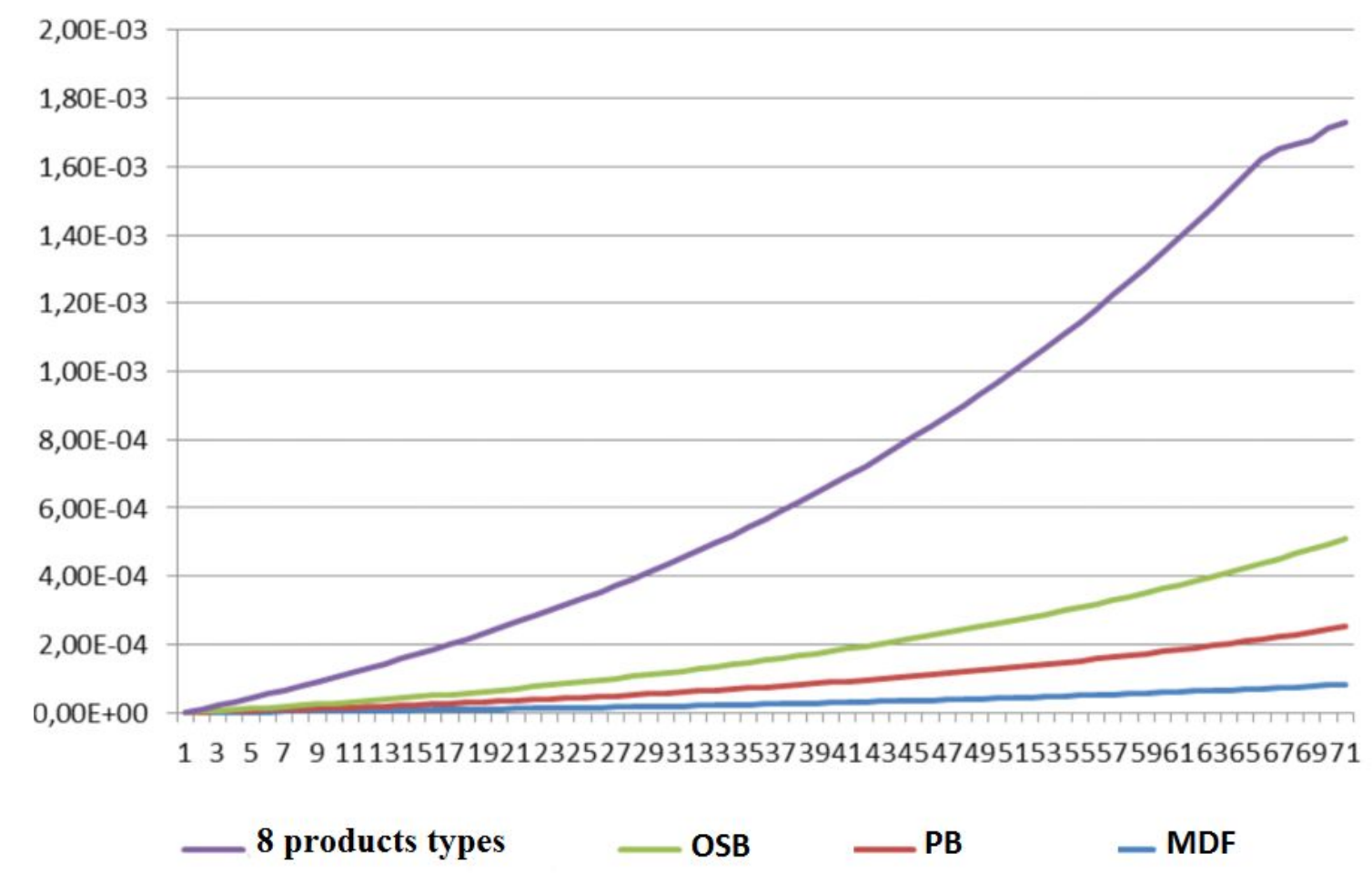

Fig. 2. Model for increasing risks of respiratory diseases in people living under conditions of exposure to formaldehyde excreted in the air of residential buildings from a number of construction and finishing materials. 
Health risk parameters to the consumers of construction and finishing materials that excrete harmful impurities into internal environment of premises, when living under specified conditions of exposure to formaldehyde, starting from 0 years

\begin{tabular}{|c|c|c|c|c|c|}
\hline Period of exposure & Linoleum & MDF & PB & OSB & 8 types of products \\
\hline 0 & $0,00 \mathrm{E}+00$ & $0,00 \mathrm{E}+00$ & $0,00 \mathrm{E}+00$ & $0,00 \mathrm{E}+00$ & $0,00 \mathrm{E}+00$ \\
\hline 1 & $4,55 \mathrm{E}-07$ & $9,28 \mathrm{E}-07$ & $9,28 \mathrm{E}-07$ & $1,42 \mathrm{E}-06$ & $7,60 \mathrm{E}-06$ \\
\hline 2 & $9,21 \mathrm{E}-07$ & $1,88 \mathrm{E}-06$ & $1,88 \mathrm{E}-06$ & $2,88 \mathrm{E}-06$ & $1,54 \mathrm{E}-05$ \\
\hline 3 & $1,40 \mathrm{E}-06$ & $2,85 \mathrm{E}-06$ & $2,85 \mathrm{E}-06$ & $4,37 \mathrm{E}-06$ & $2,34 \mathrm{E}-05$ \\
\hline 4 & $1,89 \mathrm{E}-06$ & $3,85 \mathrm{E}-06$ & $3,85 \mathrm{E}-06$ & $5,89 \mathrm{E}-06$ & $3,15 \mathrm{E}-05$ \\
\hline 5 & $2,39 \mathrm{E}-06$ & $4,88 \mathrm{E}-06$ & $4,88 \mathrm{E}-06$ & $7,46 \mathrm{E}-06$ & $3,99 \mathrm{E}-05$ \\
\hline 12 & $6,26 \mathrm{E}-06$ & $1,28 \mathrm{E}-05$ & $1,28 \mathrm{E}-05$ & $1,95 \mathrm{E}-05$ & $1,05 \mathrm{E}-04$ \\
\hline 25 & $1,54 \mathrm{E}-05$ & $3,15 \mathrm{E}-05$ & $3,15 \mathrm{E}-05$ & $4,82 \mathrm{E}-05$ & $2,58 \mathrm{E}-04$ \\
\hline 30 & $1,98 \mathrm{E}-05$ & $4,05 \mathrm{E}-05$ & $4,05 \mathrm{E}-05$ & $6,19 \mathrm{E}-05$ & $3,31 \mathrm{E}-04$ \\
\hline 35 & $2,48 \mathrm{E}-05$ & $5,05 \mathrm{E}-05$ & $5,05 \mathrm{E}-05$ & $7,73 \mathrm{E}-05$ & $4,14 \mathrm{E}-04$ \\
\hline 40 & $3,03 \mathrm{E}-05$ & $6,19 \mathrm{E}-05$ & $6,19 \mathrm{E}-05$ & $9,48 \mathrm{E}-05$ & $5,07 \mathrm{E}-04$ \\
\hline 42 & $3,28 \mathrm{E}-05$ & $6,69 \mathrm{E}-05$ & $6,69 \mathrm{E}-05$ & $1,02 \mathrm{E}-04$ & $5,47 \mathrm{E}-04$ \\
\hline 45 & $3,66 \mathrm{E}-05$ & $7,48 \mathrm{E}-05$ & $7,48 \mathrm{E}-05$ & $1,14 \mathrm{E}-04$ & $6,12 \mathrm{E}-04$ \\
\hline 50 & $4,38 \mathrm{E}-05$ & $8,93 \mathrm{E}-05$ & $8,93 \mathrm{E}-05$ & $1,37 \mathrm{E}-04$ & $7,31 \mathrm{E}-04$ \\
\hline 55 & $5,18 \mathrm{E}-05$ & $1,06 \mathrm{E}-04$ & $1,06 \mathrm{E}-04$ & $1,62 \mathrm{E}-04$ & $8,65 \mathrm{E}-04$ \\
\hline 60 & $6,08 \mathrm{E}-05$ & $1,24 \mathrm{E}-04$ & $1,24 \mathrm{E}-04$ & $1,90 \mathrm{E}-04$ & $1,02 \mathrm{E}-03$ \\
\hline 65 & $7,11 \mathrm{E}-05$ & $1,45 \mathrm{E}-04$ & $1,45 \mathrm{E}-04$ & $2,22 \mathrm{E}-04$ & $1,19 \mathrm{E}-03$ \\
\hline 70 & $8,26 \mathrm{E}-05$ & $1,69 \mathrm{E}-04$ & $1,69 \mathrm{E}-04$ & $2,58 \mathrm{E}-04$ & $1,22 \mathrm{E}-03$ \\
\hline
\end{tabular}

The resulting mathematical model made it possible to assess the additional risks that being formed for the residents health both with a separate type of product, for instance, wood-fiberboards (MDF), particle board (PB), oriented strand board (OSB), as well as their combination. A graphical representation example of the risk evolution is shown in Fig. 2.

As the criteria for a risk profile, we used the recommended scale, the risk of serious illness or death, according thereto, was considered acceptable, if it made not more than $1^{\bullet} 10^{-4}$ [17]. Exceeding this level was considered as the situation of unacceptable risk.

It's established that a number of materials (linoleum, fiber-board, insulation, etc.), if used separately, do not form unacceptable health risk during the maximum possible exposure period, which was assumed to be 70 years, when living under the specified conditions of exposure to formaldehyde from 0 years.
For a number of products types (particle boards, mineral wool, OSB plates), the critical time point for the transition to the "unacceptable" category is the periods of 15-20 years or longer. However, the most significant finding obtained was the conclusion that cumulative use of a number of durable goods forms unacceptable risks to the health of consumers already after 10-12 years of exposure (please, see the table above).

The results allowed for predicting the unacceptable risk formation scenario for the people living in precast frame houses. The obtained data, among others, provided basis for a conclusion of unacceptability for the people to keep living in the already populated houses, and the inexpediency of using the still uninhabited houses of the studied series for permanent residence.

Conclusions. The assessment of the health risk for consumers of durable products is an extremely urgent and compulsory procedure that requires methodological approaches allow- 
ing considerations of the risks increasing in a long term.

The obtained results show that products compliance with the established standards is not always a guarantee for the absence of unacceptable health risks, which should be taken into account, in particular, when making decisions on the combined application of certain goods, or when informing users about the risks.
The developed approaches that take into account evolution (growth) of negative health effects in the long-term impact of consumer products are adequate to the tasks for assessing risks of durable consumer goods, and can be used to substantiate a wide range of management decisions aimed at ensuring sanitary and epidemiological well-being of the population

\section{References}

1. Aloev V.Z., Zhirikova Z.M., Tarchokova M.A. Issledovanie gazoobraznykh produktov destruktsii polimernykh materialov v usloviyakh dlitel'nogo teplovogo stareniya. NovaInfo.Ru, 2016, vol. 2, no. 55, pp. 12-18 (in Russian).

2. Arnautov O.V. O sovershenstvovanii mekhanizmov ustanovleniya i izmeneniya pokazatelei kachestva i bezopasnosti pishchevoi produktsii $\mathrm{v}$ normativnykh i pravovykh aktakh Evraziiskogo Ekonomicheskogo Soyuza [On improvement of the mechanism for establishing and changing indicators of quality and food safety in the regulatory and legal acts of the Eurasian Economical Union]. Voprosy pitani$y a, 2016$, vol. 85, no. 1, pp. 110-116 (in Russian).

3. Elovskaya L.T., Prokopenko L.V. Garmonizatsiya otechestvennogo i zarubezhnogo sanitarnogo zakonodatel'stva po probleme promyshlennykh aerozolei [Harmonization of national and foreign sanitary laws on industrial aerosols]. Meditsina truda i promyshlennaya ekologiya, 2014, no. 2, pp. 1-5 (in Russian).

4. Zaitseva N.V., Lebedeva-Nesevrya N.A Podkhody k postroeniyu effektivnoi regional'noi sistemy informirovaniya o riskakh zdorov'yu [Methodological approaches to building of regional system of health risks information]. Zdorov'e sem'i - 21 vek, 2010, no. 4, pp. 8 (in Russian).

5. Zibarev P.V., Zubkova T.P. Ekologicheskaya bezopasnost' polimernykh stroitel'nykh materialov [Ecological safety of polymer construction materials]. Ekologiya promyshlennogo proizvodstva, 2007, no. 2, pp. 27-33 (in Russian).

6. Braubach M., Heroux M.E., Korol N., Paunovic E., Zastenskaya I. Znachenie zhilishchnykh uslovii i gorodskoi sredy dlya zdorov'ya [The value of housing conditions and urban environment for the health]. Gigiena i sanitariya, 2014, vol. 93, no. 1, pp. 9-15 (in Russian).

7. Kamaltdinov M.R., Kiryanov D.A. Primenenie rekurrentnykh sootnoshenii dlya otsenki integral'nogo riska zdorov'yu naseleniya [The application of recurrent relations for integrated health risk assessment]. Zdorov'e sem'i - 21 vek, 2011, no. 3, pp. 6 (in Russian).

8. Kiselev A.V., Mel'tser A.V. Informirovanie o riske - metodologicheskie aspekty obespecheniya sanepidblagopoluchiya naseleniya [Risk communication: Methodological aspects of sanitary and epidemiological welfare of population]. Profilakticheskaya $i$ klinicheskaya meditsina, 2014, vol. 53, no. 4, pp. 6-9 (in Russian).

9. Maevskaya S.V., Presnikov O.N. Issledovanie faktorov, vliyayushchikh na vybor materialov pri stroitel'stve derevyannogo doma [Examination of factors which influence the choice of materials applied in constructing a wood house]. Molodoi uchenyi: vyzovy i perspektivy: Sbornik statei po materialam VI mezhdunarodnoi nauchno-prakticheskoi konferentsii [A young scientist: challenges and prospects: Collected articles and materials of the VI international theoretical and practical conference]. Moscow, Internauka Publ., 2016, pp. 144-152 (in Russian).

10. Zaitseva N.V., Shur P.Z., May I.V., Kiryanov D.A. Metodicheskie podkhody k otsenke integral'nogo riska zdorov'yu naseleniya na osnove evolyutsionnykh matematicheskikh modelei [Approaches to the assessment of integrated health risk population based on evolution of mathematical models]. Zdorov'e naseleniya i sreda obitaniya, 2011, no. 10, pp. 6-9 (in Russian).

11. Zaitseva N.V., Shur P.Z., Kiryanov D.A., Kamaltdinov M.R., Tsinker M.Yu. Metodicheskie podkhody $\mathrm{k}$ otsenke populyatsionnogo riska zdorov'yu na osnove evolyutsionnykh modelei [Methodical 
approaches for health population risk estimation based evolution models]. Zdorov'e naseleniya $i$ sreda obitaniya, 2013, vol. 238, no. 1, pp. 4-6 (in Russian).

12. Metodologiya otsenki riskov zdorov'yu naseleniya pri vozdeistvii khimicheskikh, fizicheskikh i biologicheskikh faktorov dlya opredeleniya pokazatelei bezopasnosti produktsii (tovarov) [Methodology for assessing population health risks occurring under exposure to chemical, physical, and biological factors for determining products safety parameters]. Moscow, Yumanite-media, 2014, 120 p. (inRussian).

13. Zaitseva N.V., Tutel'yan V.A., Shur P.Z., Khotimchenko S.A., Sheveleva S.A. Opyt obosnovaniya gigienicheskikh normativov bezopasnosti pishchevykh produktov s ispol'zovaniem kriteriev riska zdorov'yu naseleniya [Experience of justification of hygienic standards of food safety with the use of criteria for the risk for population health]. Gigiena i sanitariya, 2014, vol. 93, no. 5, pp. 70-74 (in Russian).

14. Avaliani S.L., Novikov S.M., Shashina T.A., Skvortsova N.S., Mishina A.L. Problemy garmonizatsii normativov atmosfernykh zagryaznenii i puti ikh resheniya [Problems and ways of solutions to harmonize standards for air pollution]. Gigiena $i$ sanitariya, 2012, no. 5, pp. 75-78 (in Russian).

15. Rukovodstvo po ocenke riska dlja zdorov'ja naselenija pri vozdejstvii himicheskih veshhestv, zagrjaznjajushhih okruzhajushhuju sredu R 2.1.10.1920-04 [Guide to health risk assessment when exposed to chemicals polluting the environment 2.1.10.1920-04]. Moscow, Federal'nyj centr Gossanjepidnadzora Minzdrava Rossii publ., 2004, 143 p. (in Russian).

16. Rakhmanin Yu.A., Sinitsyna O.O. Sostoyanie i aktualizatsiya zadach po sovershenstvovaniyu nauchno-metodologicheskikh i normativno-pravovykh osnov $\mathrm{v}$ oblasti ekologii cheloveka i gigieny okruzhayushchei sredy [Status and actualization of tasks to improve the scientific-methodological and regulatory frameworks in the field of human ecology and environmental hygiene]. Gigiena $i$ sanitariya, 2013, no. 5, pp. 4-10.

17. Yartsev V.P., Erofeev A.V. Issledovanie raboty dekorativnykh plit v real'nykh usloviyakh ekspluatatsii [Study of Work of Decorative Plates under Operation Conditions]. Promyshlennoe $i$ grazhdanskoe stroitel'stvo, 2015, no. 1, pp. 24-27 (in Russian).

18. Norrback D., Wieslander G., Nordstrom K., Walinder R. Asthma symptoms in relation to measured building dampness in upper concrete floor construction and 2-ethyl-1-hexanol in indoor air. Int J. Tuberc. Lung. Dis, 2000, no. 4, pp. 1016-1025.

19. Global burden of disease 2004 update: disability weights for diseases and conditions. Geneva, World Health Organization Publ., 2008, 9 p.

20. Our cities, our health, our future. Acting on social determinants for health equity in urban areas. Geneva, World Health Organization Publ., 2008, 199 p.

21. Jarnstrom H., Saarela K., Pasanen A.-L., Kalliokoski P. Reference values for structure emissions measured on site in new residential buildings in Finland. Atmos Environ, 2007, vol. 41, pp. 2290-2302.

22. Tuomainen A., Seuri M., Sieppi A. Indoor air quality and health problems associated with damp floor coverings. Int Arch. Occup. Environ. Health, 2004, vol. 77, pp. 222-226.

23. Wilke O., Jann O., Brodner D. VOC- and SVOC-emissions from adhesives, floor coverings and complete floor structures // Indoor Air. - 2004, vol.14, no. 8, pp. 98-107.

24. Yu C, Crump D. A review of the emission of VOCs from polymeric materials used in buildings. Build Environ, 1998, no. 33, pp. 357-374.

May I.V., Nikiforova N.V., Khoroshavin V.A. Methodological approaches and practices for assessing consumers' health risks caused by durable goods (on the example of construction and finishing materials). Health Risk Analysis, 2017, no. 2, pp. 25-34. DOI: 10.21668/health.risk/2017.2.03.eng

Received: 08.02.2017

Accepted: 06.06.2017

Published: 30.06.2017 
UDC 614.8.067

DOI: 10.21668/health.risk/2017.2.04.eng

\section{ANALYZING AND DEVELOPING CRITERIA FOR ASSESSING OCCUPATIONAL TRAUMATISM RISKS BASING ON «BEST PRACTICE CODE»*}

\section{S.P. Levashov}

Kurgan State University, 25 Gogolya Str., Kurgan, 640669, Russian Federation

A system of managing occupational risks is now being implemented in the Russian Federation; it implies developing mechanisms of their assessment. The article presents an assessment procedure for assessing occupational traumatism risks as a part of methodology for complex occupational risks assessment. Occupational traumatism risk assessment is based on such criteria as predicted traumatism frequency caused by priority risk factors for examined groups (discrete criteria of traumatism risks) and frequency diagram depending on consequences of injuries caused by priority risk factors. They are integral criteria of traumatism risks (known as $F-N$ curves). «Best practice code» means traumatism risks levels which exist now in countries with high occupational safety.

Our research objects were cases and circumstances of traumatism occurring among such an occupational group as «drivers and operators of mobile equipment». We detected that increased risks levels occurred due to a limited number of factors from each group of variables and it, in general, corresponded to Pareto principle. We obtained a dependence of $y=c \times e^{-b x}$ type ( $F-N$ curve analogue), which described correlation between relative frequency of injuries and gravity of damage caused by them as a median of temporary disability of workers from the examined occupational group $\left(R^{2}>0,9\right)$. The obtained equations for approximating curve can be criterial in assessing injuring circumstances significance and risk levels for workers from relevant occupational groups in industry and agriculture in the Russian Federation.

Assessment results and assessing priority risks and factors causing them give a possibility to make decisions related to developing strategies, programs, techniques, and activities aimed at raising workers' safety in the examined occupational group.

Key words: occupational risk, risk factor, traumatism, risk assessment criteria, принци Pareto principle, workers' safety, best practice code.

A standard set of activities which are to be performed by any employer necessarily includes occupational risks assessment. Traumatism risk management is a vital task for a lot of industries and it is considered in works by both Russian and foreign researchers [4, 7, 9-11,
12-18, 20]. The order issued by the RF Ministry of Labor and Social Protection ${ }^{1}$ fixes the job responsibility of executives and labor protection specialists at all enterprises and organizations to perform the complete set of activities on detecting, assessing and managing oc-

(C) Levashov S.P., 2017

Sergey P. Levashov - Corresponding Member of the International Academy of Sciences, Ecology and Life Safety, Candidate of Technical Sciences, Associate professor at Ecology and Life Safety Department (email: spl57@mail.ru; tel.: +7 (3522) 23-20-92).

* The work is performed within the frameworks of the grant RFFI 14-46-00008 Theory and methodology of assessing occupational risks for workers employed at industrial enterprises in the RF.

${ }^{1}$ On fixing the Integrated job description reference book on executives, specialists, and clerks positions: section «Job descriptions of executives and labor protection specialists positions» [web-source]: The Order issued by the RF Ministry of labor and Social Protection No. 559H dated May 17, 2012. // Rossiskaya gazeta. - 2012. - June 22. - No. 141.- URL: https://rg.ru/2012/06/22/doljnosti-dok.html (date of visit June 11, 2016).

${ }^{2}$ On obligatory social insurance against industrial accidents and occupational diseases: Federal law No. 125 dated July 24, 1998. [web-source]. - URL: http://docs.cntd.ru/document/901713539 (date of visit June 23, 2016).

${ }^{3}$ Regulations on the Labor protection and Working Conditions Department of the RF Ministry of Labor and Social Protection [web-source] / fixed by the order of the RF Ministry of Labor and Social Protection No.31 dated July 25, 2012. - URL: http://www.rosmintrud.ru/docs/mintrud/salary/3 (date of visit June 11, 2016). 
cupational risks. But still a concept of occupational risks assessment in Russia hasn't been developed as a practical instrument yet.

According to the existing federal law on insurance against accidents ${ }^{2}$ and regulations on Labor Protection and Working Conditions Department and Social Insurance Fund (SIF) ${ }^{3}$ working conditions and labor protection as well as occupational risks levels are monitored in our country as per economic activity and the $\mathrm{RF}$ regions.

Organizations and/or private entrepreneurs (juridical persons) which are included into the statistical register are statistical observation objects in both cases. Statistical information provided by the SIF is used as a ground for fixing "occupational risk categories" as well as for choice on priority actions aimed at their elimination.

Methodological problems. We examined statistical data provided by the SIF Kurgan regional office for a period of 1999 to 2012; the results revealed that agricultural production was one of the most injury-prone industries both in terms of the total number of grave injuries and total number of fatalities (2160 cases). And more than $47 \%$ of all the injuries occurred in the basic occupational group 8300 "Drivers and operators of mobile equipment" [8].

The analysis results showed that causes and circumstances of injuries occurring in certain occupational groups differed significantly both from each other within a group and from those which were characteristic for agricultural production workers as a whole. This fact proves that an existing approach to occupational risks assessment basing on the information on industrial threats as per industries data is hardly relevant. And yet, analysis of reports on industrial accidents (so called $\mathrm{H}-1$ forms) revealed that injuries circumstances for a specific basic occupational group are in general rather identical.

The results of traumatism analysis and screening risk assessment on the basis of criteria given in the State Standard P 51901.23-
2012 [3] showed that risks for workers from 8300 occupational group, "Drivers and operators of mobile equipment", were extremely high. It made for the necessity to perform a detailed analysis aimed at increasing risk assessment validity.

Research goal was to give grounds for methodology of assessment criteria creation and occupational traumatism risks assessment on the example of a basic occupational group.

Data and methods. We identified and ranked priority risk factors (risk indexes) which determined high traumatism level in the course of the detailed research (Table 1).

The statistical analysis results prove a hypothesis stated in works $[1,5,6]$ that accidents and injuries caused by them are not casual events. They are the result of cause-effect interactions within "a worker - working environment" system and can therefore be predicted and prevented.

In this context, planning and implementing activities aimed at increasing workers' safety should be performed as per significance of injuries causes and consequences; "a worker - working environment" system is to be developed via improvement of elements which are relatively more significant.

We used Fault Tree ${ }^{4}$ software to assess cause-effect relations significance. We applied calculation modules system in our analysis and accomplished point estimates of probability of both the system failure as a whole (an injury itself) and intermediate events as well. We determined minimal logical expressions for calculating events probability and performed point estimates of probable emergency combinations; the paper presents the results of calculating significance of initial events and their combinations.

Criteria choice and foundation. Foreign practices prove that tools and methods used for calculating risk and its components should provide obtaining of such data which in their form are similar to parameters applied for describing threshold (criterial) values of ultimate, permis-

\footnotetext{
${ }^{4}$ Fault Tree Analysis (FTA) [web-source] // Wikipedia: the free encyclopedia. - URL: https://en.wikipedia.org/ wiki/Fault_tree_analysis (date of visit July 18, 2016)
} 
sible or acceptable risks [6].

Risk criteria determination involves choice and foundation of parameters which determine monitoring system efficiency concerning set goals. According to our research goal and recommendations given in the State Standard 51901-2002 [2] as well, we chose the following parameters as risk assessment criteria:

Table 1

Register of risks for "Drivers and operators of mobile equipment" occupational group (fragment)

\begin{tabular}{|c|c|c|c|c|c|}
\hline \multirow{2}{*}{$\begin{array}{l}\text { Accident circum- } \\
\text { stances identifier }\end{array}$} & \multirow{2}{*}{$\begin{array}{c}\text { Accident circumstances } \\
\text { denomination and } \\
\text { description }\end{array}$} & \multirow{2}{*}{$\begin{array}{l}\text { Circumstances } \\
\text { occurrence } \\
\text { probability }(L)^{*}\end{array}$} & \multicolumn{2}{|c|}{$\begin{array}{c}\text { Consequences of circumstances } \\
\text { occurrence }(I)\end{array}$} & \multirow{2}{*}{$\begin{array}{c}\text { Risk as- } \\
\text { sessment } \\
(I L)\end{array}$} \\
\hline & & & Gravity & Probability $^{* *}$ & \\
\hline \multicolumn{6}{|c|}{ Event or impact $(E)$} \\
\hline E1 & $\begin{array}{l}\text { Pinching by objects or } \\
\text { between objects }\end{array}$ & 0,27 & $\begin{array}{l}\text { Lethal } \\
\text { grave } \\
\text { mild }\end{array}$ & $\begin{array}{l}0,0570 \\
0,0976 \\
0,8454\end{array}$ & $\begin{array}{l}0,01539 \\
0,02635 \\
0,22826\end{array}$ \\
\hline E2 & Fall of an injured & 0,25 & $\begin{array}{l}\text { Lethal } \\
\text { grave } \\
\text { mild }\end{array}$ & $\begin{array}{l}0,0137 \\
0,0747 \\
0,9116 \\
\end{array}$ & $\begin{array}{l}0,00343 \\
0,01868 \\
0,22790 \\
\end{array}$ \\
\hline E3 & $\begin{array}{l}\text { Contact injures or colli- } \\
\text { sions }\end{array}$ & 0,19 & $\begin{array}{l}\text { Lethal } \\
\text { grave } \\
\text { mild } \\
\end{array}$ & $\begin{array}{l}0,0372 \\
0,0705 \\
0,8923\end{array}$ & $\begin{array}{l}0,00707 \\
0,01340 \\
0,16954 \\
\end{array}$ \\
\hline \multicolumn{6}{|c|}{ Injury source $(S)$} \\
\hline S1 & $\begin{array}{l}\text { Machines and mecha- } \\
\text { nisms }\end{array}$ & 0,28 & $\begin{array}{l}\text { Lethal } \\
\text { grave } \\
\text { mild }\end{array}$ & $\begin{array}{l}0,0427 \\
0,0843 \\
0,8730 \\
\end{array}$ & $\begin{array}{l}0,01196 \\
0,02360 \\
0,24444 \\
\end{array}$ \\
\hline S2 & $\begin{array}{l}\text { A worker's actions or } \\
\text { movement }\end{array}$ & 0,18 & $\begin{array}{l}\text { Lethal } \\
\text { grave } \\
\text { mild } \\
\end{array}$ & $\begin{array}{l}0,0192 \\
0,0652 \\
0,9156 \\
\end{array}$ & $\begin{array}{l}0,00346 \\
0,01174 \\
0,16481 \\
\end{array}$ \\
\hline S3 & Vehicles & 0,16 & $\begin{array}{l}\text { Lethal } \\
\text { grave } \\
\text { mild } \\
\end{array}$ & $\begin{array}{l}0,0504 \\
0,0817 \\
0,8679 \\
\end{array}$ & $\begin{array}{l}0,00806 \\
0,01307 \\
0,13886 \\
\end{array}$ \\
\hline \multicolumn{6}{|c|}{ Injury type $(T)$} \\
\hline T1 & Open wounds & 0,28 & $\begin{array}{l}\text { Lethal } \\
\text { grave } \\
\text { mild }\end{array}$ & $\begin{array}{l}0,0327 \\
0,1176 \\
0,8497\end{array}$ & $\begin{array}{l}0,00916 \\
0,03293 \\
0,23792 \\
\end{array}$ \\
\hline $\mathrm{T} 2$ & $\begin{array}{l}\text { Subcutaneous wounds and } \\
\text { injuries (pinching) }\end{array}$ & 0,28 & $\begin{array}{l}\text { Lethal } \\
\text { grave } \\
\text { mild } \\
\end{array}$ & $\begin{array}{c}0 \\
0,1778 \\
0,8222\end{array}$ & $\begin{array}{c}0 \\
0,04978 \\
0,23022 \\
\end{array}$ \\
\hline T3 & Fractures & 0,19 & $\begin{array}{l}\text { Lethal } \\
\text { grave } \\
\text { mild } \\
\end{array}$ & $\begin{array}{l}0,0592 \\
0,2368 \\
0,7040\end{array}$ & $\begin{array}{l}0,01125 \\
0,04499 \\
0,13376 \\
\end{array}$ \\
\hline \multicolumn{6}{|c|}{ Body part $(B)$} \\
\hline B1 & Upper extremities & 0,37 & $\begin{array}{l}\text { Lethal } \\
\text { grave } \\
\text { mild }\end{array}$ & $\begin{array}{l}0,0036 \\
0,0357 \\
0,9607 \\
\end{array}$ & $\begin{array}{l}0,00133 \\
0,01321 \\
0,35546\end{array}$ \\
\hline B2 & Lower extremities & 0,25 & \begin{tabular}{|l}
$\begin{array}{l}\text { Lethal } \\
\text { grave } \\
\text { mild }\end{array}$ \\
\end{tabular} & $\begin{array}{c}0 \\
0,0859 \\
0,9141 \\
\end{array}$ & $\begin{array}{c}0 \\
0,02148 \\
0,22853 \\
\end{array}$ \\
\hline B3 & Head & 0,12 & \begin{tabular}{|l}
$\begin{array}{l}\text { Lethal } \\
\text { grave } \\
\text { mild }\end{array}$ \\
\end{tabular} & $\begin{array}{c}0,0536 \\
0,0804 \\
0,8661 \\
\end{array}$ & $\begin{array}{l}0,00643 \\
0,00965 \\
0,10393 \\
\end{array}$ \\
\hline
\end{tabular}

Note:

* - as a share of the total number of accidents with occupational group representatives;

** - as a share of the total number of accidents caused by such circumstances. 
a) a predictable frequency of injuries caused by priority risk factors for workers from the examined occupational group (discrete criteria of injuries risks);

b) frequency diagrams depending on consequences of injuries caused by priority risk factors (integral criteria of injuries risks known as $F-N$ curves).

Risk evaluation is a process of comparing an evaluated risk with these risk criteria in order to determine its significance. Here we check if a risk in this situation is greater than an acceptable one which is considered to be permissible within the existing social values. Absence of occupational traumatism risks criteria in the $\mathrm{RF}$ legal regulations as well as absence of analytical tools to calculate such risks made it necessary to use relevant analogues from foreign practices as evaluation criteria.

«Best practice code» («Best practical solution») is a tool which provides practical means and relevant examples from the best domestic or foreign practices. In our context we accepted traumatism risk levels which exist now in countries with high occupational safety as a «Best practice code». "Relevance presumption" principle implies that risks which are acceptable for similar occupations, operations, production processes or activities, can be used as a standard, that is, relevant known risk values are used as criteria.

As traumatism levels in the RF are multiply higher than those existing in the EU countries and the USA, we chose traumatism parameters in the US agricultural sector as "best practice code" (Figure 1).

Our choice was determined by the fact that information resources of the US Bureau of Labor Statistics which contain more than 20 million entries are a systematized database on accidents for a period of time starting with 1992 and up to present. The data are given on the official web-site of The US National Institute for Occupational Safety and Health ${ }^{5}$.

"Agricultural equipment operators" occupational subgroup 45-2091 was chosen as an ana- logue for our Russian "Drivers and operators of mobile equipment" occupational group. As per data provided by the US Bureau of Labor Statistics, this group consisted of 221.32 thousand workers over 2004-2013; number of non-lethal injuries over the same period amounted to 5,540. 122 people died.

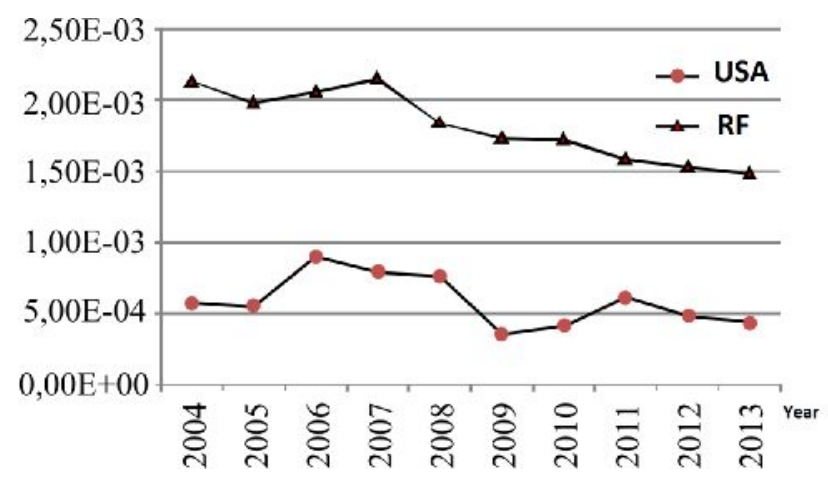

Figure 1. Non-lethal traumatism risks dynamics in agriculture

Analysis of injuries conditions and circumstances. Elimination of causes which make for or directly lead to accidents is one of the most important elements of risk management. To identify dangers related to occupational activities of injured we analyzed injuries circumstances as per methodology presented in [5]. traumatism dynamics analysis revealed that over 2004-2013 fluctuations in per cent distribution (share) of injuries caused by or related to specific factors were insignificant as they were within confidence interval boundaries $(\mu \pm 2 \sigma)$. It provided a possibility to perform statistical analysis to determine and rank priority variables/injury circumstances for workers form this occupational group.

Determination of injuries risks discrete criteria. Data on number of workers in the examined occupational group and on a number of accidents made it possible to evaluate injuries risks level.

Risks were evaluated as ratio of a number of injured workers from the "Agricultural

\footnotetext{
${ }^{5}$ The National Institute for Occupational Safety and Health (NIOSH) [web-source] // Centers for Disease Control and Prevention. - URL: http://www.cdc.gov/niosh/ (date of visit August 15, 2015).
} 
equipment operators" occupational group $(n)$ to the total number of workers in this occupational group $(N)$ :

$$
R=n / N \text {. }
$$

Non-lethal injuries risks analysis in the RF over 2004-2013 (see Figure 1) revealed that the observed descending trend of these parameters was within confidence interval boundaries $(\mu \pm$
$2 \sigma)$. This regularity was detected for the whole examined set of circumstances and conditions, that is, as per injury character; as per localization of an injury on a body; as per injury source as well as per impact type (accident type). The results of the performed analysis are shown in Figure 2.

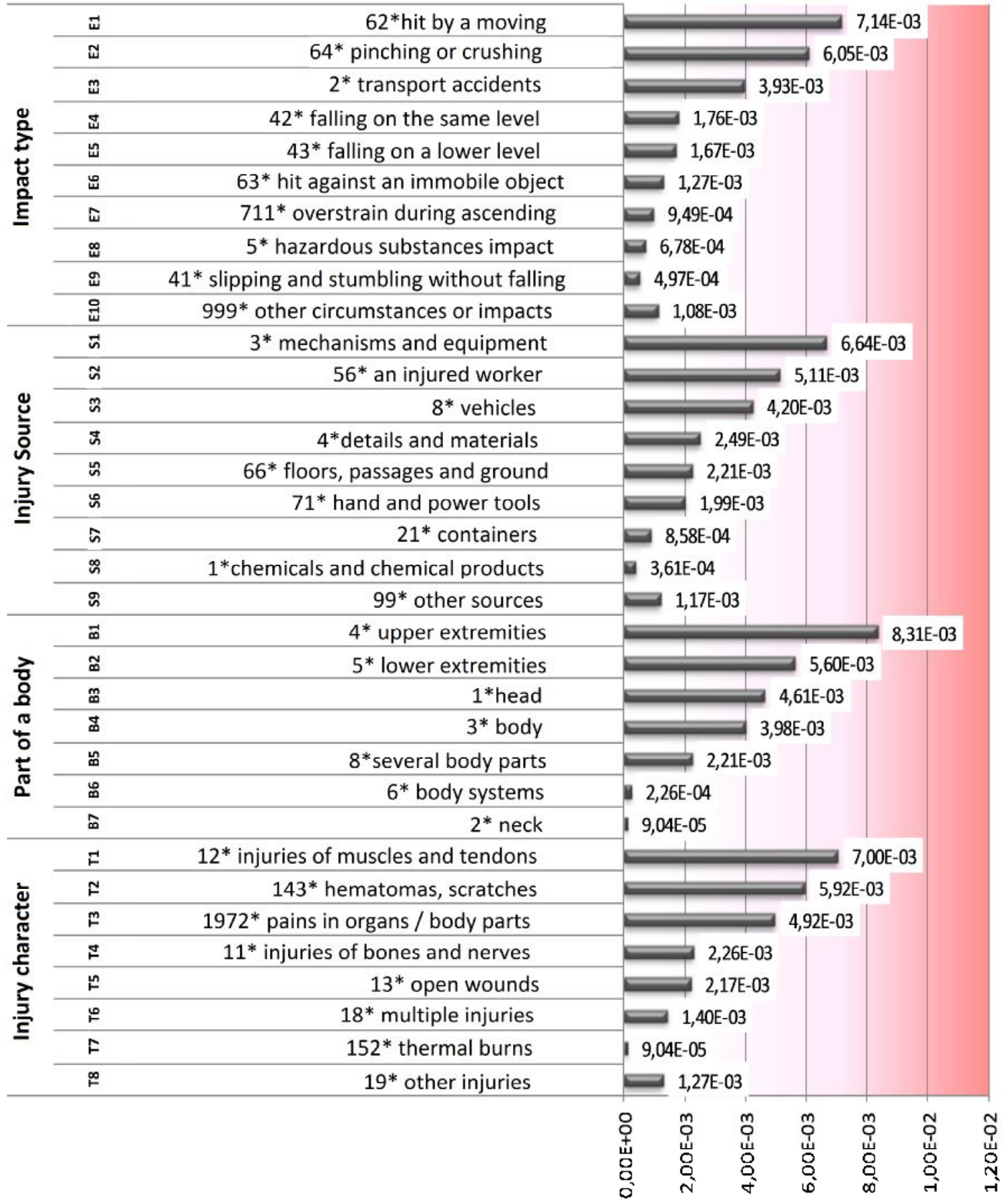

Figure 2. Non-lethal injuries risks 
2-3 factors from each group of variables are in increased risks zone which on the whole corresponds to Pareto principle: $20 \%$ means which are required to solve a problem completely, help to solve $80 \%$ of it. It seems obvious that it is those risks which are priority ones in decision-making on strategies and measures aimed at increasing safety of workers in the analyzed occupational group. Basing on traumatism levels comparison, we can state that quantitative risks values in the US agricultural sector are criterial when workers safety for analogical occupations in the RF is assessed.

Analysis of discrete traumatism risks levels allows to evaluate an injury probability without taking their consequences gravity into account. But still data on damage gravity are most significant in developing injuries prevention strategies as they most adequately highlight priority trends in increasing workers' safety.

Determination o injuries risks integral criteria. According to «OIICS Guidelines» [19], a number of days during which a worker

was temporarily disabled is one of the basic parameters indicating injury consequences gravity applied in the US. There are the following gradations: 1 day; 2 days; 3-5 days; 6-10 days; 11-20 days; 21-30 days; 31 days and longer, but not more than 3 months.

Figure 3 shows data on temporary disability duration distribution for workers from "Agricultural equipment operators" occupational group over 2004-2013. The results of statistical functions calculations are given in Table 2.

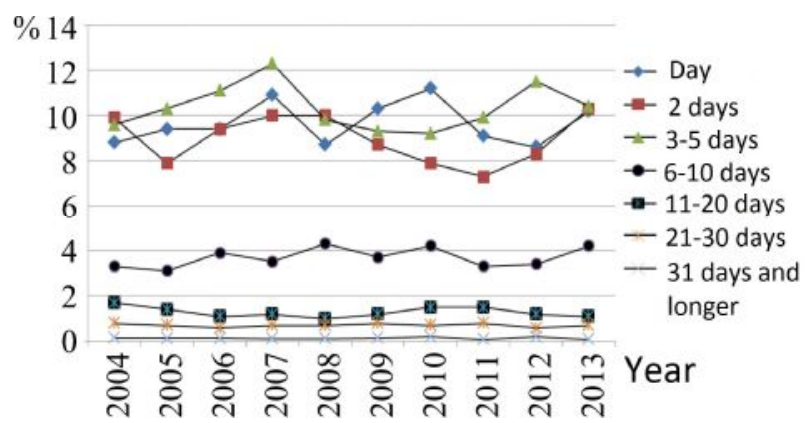

Figure 3. Temporary disability duration distribution

Table 2

Statistical functions

\begin{tabular}{|l|c|c|c|c|c|c|c|}
\hline \multirow{2}{*}{ Statistical function } & \multicolumn{7}{|c|}{ Disability duration distribution, \% } \\
\cline { 2 - 9 } & day & 2 days & $3-5$ days & $6-10$ days & 11-20 days & $21-30$ days & $\begin{array}{c}31 \text { days and } \\
\text { longer }\end{array}$ \\
\hline Median & 14,1 & 11,1 & 10,3 & 3,7 & 1,3 & 0,7 & 0,1 \\
\hline Mean deviation & 0,90 & 1,58 & 0,78 & 0,37 & 0,19 & 0,06 & 0,01 \\
\hline Standard deviation & 1,10 & 1,85 & 1,01 & 0,43 & 0,23 & 0,07 & 0,01 \\
\hline
\end{tabular}

Data analysis revealed that over the whole observation period distribution of consequences gravity probabilities $N_{i}$ was within the boundaries of confidence interval $N \pm 2 \sqrt{N}$. It makes for statistical research possibility assuming that injury distribution $N$ with certain consequences gravity $i$ remains unchanged, that is, $N_{i}=$ const with probability equal to $95 \%$.

To obtain approximating curve equation in an analytical form and to evaluate validity of the performed approximation with Excel tools, we accomplished regression analysis of the obtained data. When fitting a trend line, Excel automatically calculates $R^{2}$ value which characterizes approximation validity.
$R^{2}$ as approximation validity value is determined as per formula

$$
R^{2}=1-\frac{\sum\left(y_{i}-\hat{y}_{i}\right)^{2}}{\sum\left(y_{i}-\bar{y}\right)^{2}},
$$

where $y_{i}$ are actual values; $\hat{y}_{i}$ are approximating functions value.

The results showed that maximum value of approximation validity $R^{2}=0.9267$ corresponded to exponential distribution

$$
y=c e^{-b x}
$$

Frequency distribution median and approximating curve $y=0,5449 e^{-0,761 x}$ are given on Figure 4. 


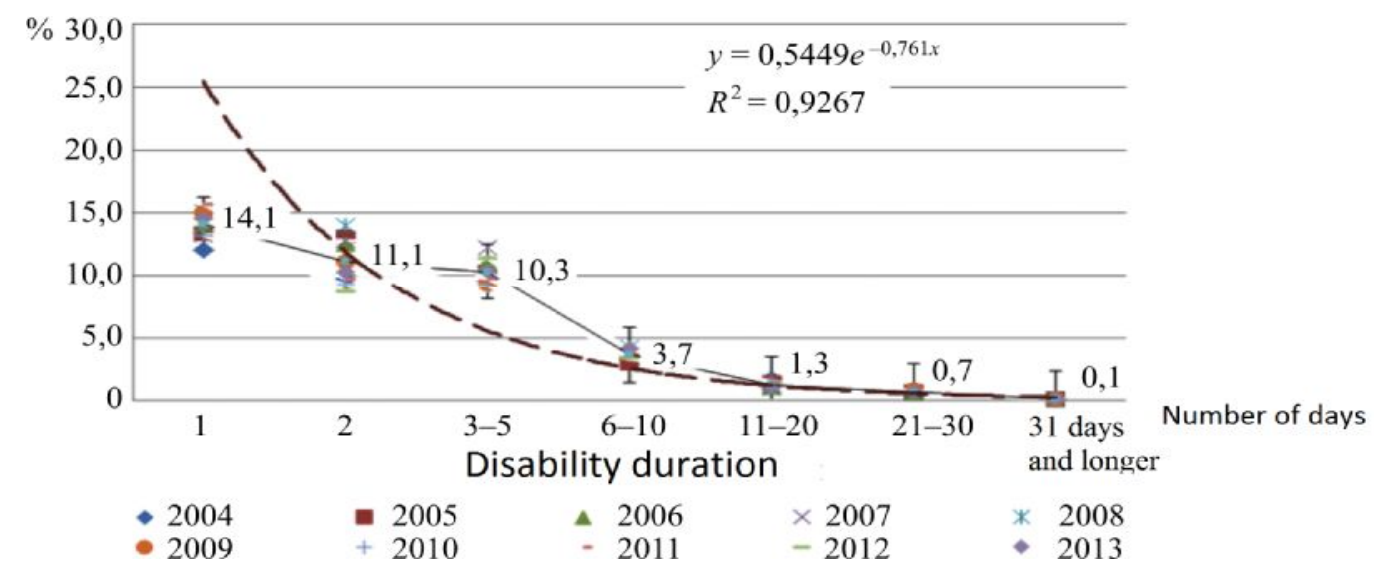

Figure 4. Correlation between relative injuries frequency and damage gravity

Table 3

Approximation curves equations

\begin{tabular}{|c|c|c|}
\hline Injury circumstances & Approximation curve equation & $\begin{array}{c}\text { Model determination } \\
\text { coefficient } \\
\left(R^{2}, p<0.05\right)\end{array}$ \\
\hline \multicolumn{3}{|c|}{ Injury character } \\
\hline Injuries of muscles and tendons & $y=0,4412 e^{-0,714 x}$ & 0,9212 \\
\hline Hematomas and scratches & $y=1,039 e^{-0,938 x}$ & 0,9605 \\
\hline Pains in organs and body parts & $y=0,5408 e^{-0,769 x}$ & 0,9542 \\
\hline \multicolumn{3}{|c|}{ Part of a body (organ) } \\
\hline Upper extremities injuries & $y=1,039 e^{-0,93 x}$ & 0,9600 \\
\hline Lower extremities injuries & $y=0,3822 e^{-0,68 x}$ & 0,9380 \\
\hline Head injuries & $y=1,4928 e^{-1,06 x}$ & 0,9785 \\
\hline \multicolumn{3}{|c|}{ Injury source } \\
\hline Mechanisms and equipment & $y=0,4857 e^{-0,732 x}$ & 0,9427 \\
\hline Injured worker & $y=0,540 e^{-0,76 x}$ & 0,9540 \\
\hline Vehicles & $y=0,3915 e^{-0,689 x}$ & 0,9421 \\
\hline \multicolumn{3}{|c|}{ Event or impact } \\
\hline Hit by a moving object & $y=0,7288 e^{-0,835 x}$ & 0,9623 \\
\hline Pinching or crushing & $y=1,1683 e^{-0,969 x}$ & 0,9575 \\
\hline Transport accidents & $y=0,3701 e^{-0,679 x}$ & 0,9410 \\
\hline
\end{tabular}

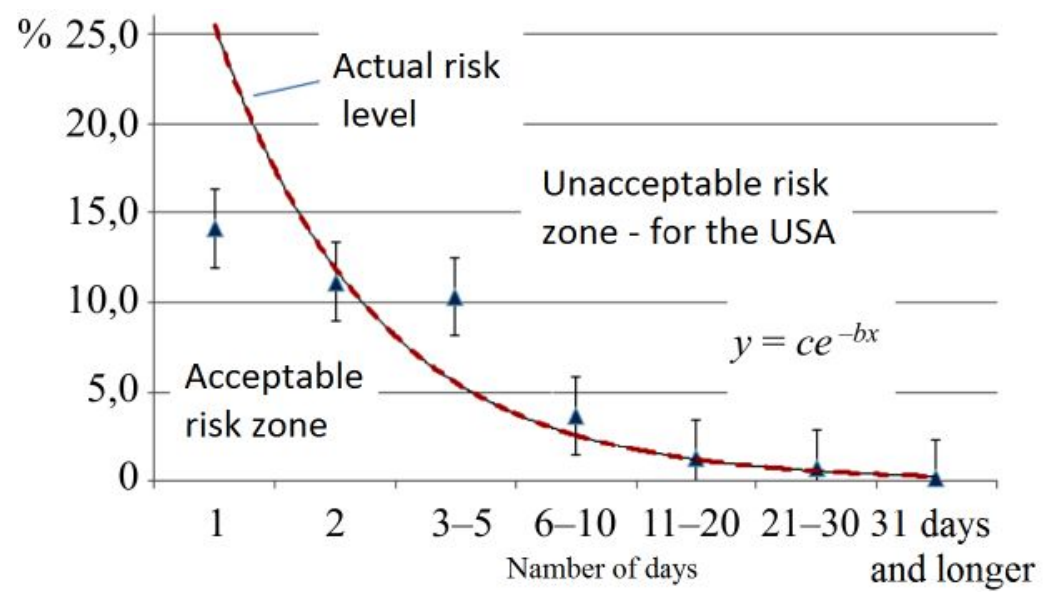

Figure 5. Correlation between relative frequency of injury circumstances and damage gravity 
The obtained dependence is in its essence an analogue of a well-known $\mathrm{F}-\mathrm{N}$-curve, which represents a graphic interpretation of correlation between an event probability and gravity. In this case the curve shows correlation between relative injuries frequency (as a \% of total number of cases) and gravity of damage caused by them (as disability duration median / period) for workers from "Agricultural equipment operators" occupational group.

Injuries risks level $(R)$ can be given as:

$$
R=f(F, N),
$$

where $F$ are discrete frequencies of accidents which caused disability days, $N$ is gravity of the given accidents consequences.

We obtained similar dependences for all detected priority risk factors during our research. Integral risk levels as per most significant injury circumstances are given in Table 3 .

So, allowing for multiply higher injury risks for workers employed at the RF agricultural enterprises (see Figure 2), we can state that $y=c e^{-b x}$ curves based on the long-term statistical observation of workers from relevant occupational groups in the USA can be used as criterial ones in evaluating acceptability of relevant injury circumstances and risk levels (Figure 5).

Conclusions. According to our research goal we took predictable frequency of injuries caused by priority risk factors for workers from the examined occupational group (discrete injuries risks criteria) and frequency diagrams depending on consequences of injuries caused by priority risk factors (integral injuries risks criteria known as $F-N$ curves) as criteria of occupational traumatism risks evaluation.

We detected that increased risks levels were caused by a limited number of factors from each group of variables which in general corresponded to Pareto principle: $20 \%$ means which are required to solve a problem completely, help to solve $80 \%$ of it.

"Relevance presumption" principle implies that risks which are acceptable for similar occupations, operations, production processes or activities, can be used as a standard, that is, relevant known risk values are used as criteria. As traumatism levels in the RF are multiply higher than those existing in the EU countries and the USA, and there aren't any standard values for occupational traumatism risks existing in the RF, we chose traumatism parameters in the US agricultural sector as a standard value.

The $y=c e^{-b x}$ dependence obtained in the course of our research is an analogue of a wellknown $F-N$-curve which shows correlation between an accident probability and gravity. In our case the curve shows correlation between relative injuries frequency and gravity of damage caused by them as a disability duration median for workers from the examined occupational group.

The research results and the approximation validity values $R^{2}>0.9$ which we obtained via regression analysis prove that the detected $y=c e^{-b x}$ dependence adequately reflects the essence of cause and effect relations between injury circumstances and consequences they have. Hence, the obtained approximating curve equations can be criterial in evaluating injury circumstances significance and risks for workers from relevant occupational groups in the RF industry and agriculture.

Results of priority risks evaluation as well as assessment of factors which determine them make it possible to take decisions related to development of strategies, programs, methods and means for increasing safety of workers from an analyzed occupational group.

\section{References}

1. Lomov O.P., Akhmetzyanov I.M., Greben'kov S.V., Levashov S.P., Terent'ev L.P. Gigienicheskie normativy. Fizicheskie faktory okruzhayushchei i proizvodstvennoi sredy: Kollektivnaya monografiya [Hygienic standards. Physical factors of the environment and occupational environment: Collective monograph]. In: O.P. Lomov ed. St. Petersburg, Professional Publ., 2013, 796 p. (in Russian). 
2. Menedzhment riska. Analiz riska tekhnologicheskikh sistem: Gosudarstvennyi standart Rossiiskoi Federatsii [Risk management. Risk analysis of technological systems: The RF State Standard 51901.1-2002.]. Available at: http: //docs.cntd.ru/document/1200030153 (22.03.2016) (in Russian).

3. Menedzhment riska. Reestr riska. Rukovodstvo po otsenke riska opasnykh sobytii dlya vklyucheniya $\mathrm{v}$ reestr riska [Risk management. Risk register. Guide on assessment of hazards risk for inclusion in risk register: The RF National Standard 51901.23-2012]. Available at: http: //docs.cntd.ru/document/1200100076 (22.03.2016) (in Russian).

4. Artem'ev V.B., Kilin A.B., Shapovalenko G.N., Osharov A.V., Radionov S.N., Kravchuk I.L. Kontseptsiya operezhayushchego kontrolya kak sredstva sushchestvennogo snizhe-niya travmatizma [Predictive control concept as a mean of substantial traumatism lowering]. Ugol', 2013, no. 5, pp. 82-85 (in Russian).

5. Levashov S.P. Manilo I.I. Otsenka riskov professional'nogo travmatizma [Occupational traumatism risk assessment]. Chelovek i trud, 2013, no. 11-12, pp. 62-70 (in Russian).

6. Levashov S.P., Shkrabak V.S. Professional'nyi risk: metodologiya monitoring i analiza [Occupational risk: Monitoring and analysis methodology]. In: V.S. Shkrabak ed. Kurgan, Izdatel'stvo Kurganskogo gosudarstvennogo universiteta Publ., 2015, 308 p. (in Russian).

7. Lisovskii V.V., Grishin V.Yu., Kravchuk I.L., Galkin A.V. Ob operativnom upravlenii riskami travmirovaniya personala: uderzhanie opasnoi proizvodstvennoi situatsii na priemlemom urovne riska [On operative managing risks of workers' traumatism: keeping a dangerous production situation at an acceptable risk level]. Ugol', 2013, no. 11, pp. 46-52 (in Russian).

8. Obshcherossiiskii klassifikator zanyatii [Russian Classification of Occupations 010-2014 (MSKZ-08)]. Available at: URL: http: //docs.cntd.ru/document/1200121893 (24.04.2016) (in Russian).

9. Pustovit A.E., Kozlov V.I. Prognozirovanie travmatizma sredi shakhterov posredstvom analiza riskov travmirovaniya [Miners traumatism forecasting by means of injury risk analysis]. Sibbezopasnost'Spassib, 2013, no. 1, pp. 234-238 (in Russian).

10. Sevast'yanov B.V., Shadrin R.O. Prognozirovanie riskov travmirovaniya rabotayushchikh v munitsipal'nykh obrazovaniyakh Udmurtskoi respubliki [Prediction of injury risks to workers employed in municipalities of the Udmurt Republic]. Problemy prognozirovaniya, 2012, no. 1, pp. 152-157 (in Russian).

11. Selivanov L.K. Otsenka riska travmirovaniya v Rossiiskoi Federatsii i federal'nykh okrugakh [Assessment of the risk of injury in the Russian Federation and federal districts]. Aktual'nye problemy aviatsii i kosmonavtiki, 2016, vol. 1, no. 12, pp. 975-977 (in Russian).

12. Suvorov S.B. Strukturirovanie riskov travmirovaniya na rabochikh mestakh [Structuring risks of traumatizing at working places]. Izvestiya vysshikh uchebnykh zavedenii. Gornyi zhurnal, 2007, no. 5, pp. 4244 (in Russian).

13. Susoeva I.V., Bukalov G.K., Repin V.M. Metod otsenki riska travmirovaniya s uchetom ushcherba na tekstil'nom predpriyatii [The Method of Estimation of Traumatizing Risks Taking into Account Damages at Textile Enterprises]. Izvestiya vysshikh uchebnykh zavedenii. Tekhnologiya tekstil'noi promyshlennosti, 2012, vol. 338, no. 2, pp. 137-141 (in Russian).

14. Feyer A., Williamson A.W. A Classification System for Causes of Occupational Accidents for Use In Preventive Strategies. Scand. J. Work Environ. Health, 1997, vol. 17, pp. 302-311.

15. Jovanović D., Bašić S., Mitrović J. Injury risk to young car drivers in traffic on territory of Republic of Serbia. Transport Problems, 2010, vol. 5, no. 2, pp. 21-30.

16. Leigh J.P., Du J., McCurdy S. A. An estimate of the U.S. government's undercount of nonfatal occupational injuries and illnesses in agriculture. Annals of Epidemiology, 2014, vol. 24, no. 4, pp. 254259.

17. Mitropoulos P., Namboodiri M. New method for measuring the safety risk of construction activities: task demand assessment. Journal of Construction Engineering and Management, 2011, vol. 137, no. 1, pp. 30-38.

18. Mosher G.A., Keren N. Analysis of safety decision-making data using event tree analysis. The Association of Technology, Management, and Applied Engineering: Conference Proceedings Papers, 2011, pp. 137-142. 
19. Occupational Injury and Illness Classification System. Centers for Disease Control and Prevention. Available at: http: //wwwn.cdc.gov/wisards/oiics/Trees/MultiTree.aspx?Year=2012 (12.02.2016).

20. Schaufler D.H., Yoder A.M., Murphy D.J., Schwab C.V., Dehart A.F. Safety and health in onfarm biomass production and processing. Journal of Agricultural Safety and Health, 2014, vol. 20, no. 4, pp. 283-299.

Levashov S.P. Analyzing and developing criteria for assessing occupational traumatism risks basing on «Best Practice Code». Health Risk Analysis, 2017, no. 2, pp. 35-44. DOI: 10.21668/health.risk/2017.2.04.eng

Received: 12.02 .2017

Accepted: 20.05.2017

Published: 30.06.2017 


\title{
RISK ASSESSMENT PRACTICE IN HYGIENIC AND EPIDEMIOLOGICAL STUDIES
}

UDC 614.7: 616.24

DOI: $10.21668 /$ health.risk/2017.2.05.eng

\section{METHODICAL APPROACHES TO MANAGING RISKS FOR ENDOCRINE DISEASES EVOLVEMENT IN CHILDREN RELATED TO IMPACTS OF ENVIRONMENTAL FACTORS OCCURING ON AREAS AIMED FOR DEVELOPMENT}

\author{
K.P. Luzhetskiy \\ Federal Scientific Center for Medical and Preventive Health Risk Management Technologies, \\ 82 Monastyrskaya Str., Perm, 614045, Russian Federation
}

It is vital to develop systems of preventing risk-associated pathology due to constantly high levels of endocrine diseases in children exposed to chemicals with trophic effects on endocrine system (lead, cadmium, manganese, chromium, nickel, benzene, phenol, formaldehyde, benzpyrene, chlorine-organic compounds, and nitrates). Applying risk management techniques is one of the most promising trends in prevention of diseases related to environmental impacts. We offer methodical approaches based on system combination of activities at various management levels aimed at improving risk-oriented model of surveillance and control. These approaches enable allowing for detected thropic risk factors in regional social-hygienic monitoring programs, implementing algorithms of case monitoring over exposed children population, and applying contemporary prevention technologies.

Social-hygienic monitoring improvement at territorial level implies stricter control and more comprehensive lists of monitored components. This can be achieved by studying compounds which form risks for endocrine system, by working out scientific-methodological grounds for accounting chemical compounds which are trophic for endocrine system, as well as by refining volumes and contents of scheduled inspections performed at high risks objects together with laboratory examination of chemical compounds including those thropic for endocrine system. Local level includes algorithms and schemes of prevention activities aimed at early detection of endocrine disorders related to chemicals impacts. When we give grounds for personified technologies of endocrine diseases prevention (alimentary disorders, physical retardation and obesity related to impacts exerted by chemicals which are trophic for endocrine system) we should remember that individual programs choice is based not only on their capacity to eliminate priority compounds determining total chemical load on a person faster but also on possibility to correct basic pathophysiological and pathomorphological disorders.

Key words: prevention system, endocrine system diseases, social-hygienic monitoring, surveillance and control, sanitary-epidemiologic wellbeing, chemical compounds with trophic impacts on endocrine system, prevention technologies.

Negative influence exerted by environmental risk factors on population health as well as prevention of diseases related to it are a challenging task; searching for ways to solve it is a leading trend in contemporary prevention medicine $[1,8,9,15,16,19]$. Over the last years attention of the international scientific community has been focused on steady growth in en-

(C) Luzhetskiy K.P., 2017

Konstantin P. Luzhetskiy - Candidate of Medical Sciences, Head of the Clinic Eco-Dependent and ProductionCaused Pathologies, Associate Professor of the Department of Human Ecology and Life Safety (e-mail: nemo@fcrisk.ru; tel.: +7 (342) 236-80-98). 
docrine pathology all over the world, especially in economically developed countries [16-18]. In the RF, population morbidity in terms of endocrine system diseases, nutrition disorders, and metabolic disorders on urbanized areas aimed for development is 1.2-1.5 higher than in rural areas $[3,6]$. There is growth in such diseases as obesity, pancreatic diabetes, and thyroid gland pathology both among adults and children living on territories with high industrial and technological potential; one can say it now looks like a true non-infectious epidemics [5, 9-14].

The State Report issued by Federal Service for Surveillance over Consumer Rights Protection and Human Well-being which is entitled "On sanitary-epidemiologic welfare of the RF population in 2014-2016" contains data on risk-associated endocrine pathology evolvement on territories where environment quality is unsatisfactory as per sanitarychemical parameters [1].

But still, if we wish to develop a unified system for preventing endocrine diseases which are associated with environmental factors impacts we need to solve certain tasks on improving social-hygienic monitoring programs, hygienic assessment, risk identification and quantitative parameterization; we should make them more concrete; we should also develop a risk-oriented model of surveillance activities [2, 4, 7]. Preventive activities programs and programs of dynamic monitoring over exposed children health are often created without allowing for risks caused by adverse impacts of environmental factors; such programs are to be adjusted. All the above-stated determined the relevance of our research and gave grounds for setting goals of this work.

Our research goal was to lower risks of environmentally-associated endocrine diseases evolvement in children living in areas aimed for development.

The existing level of children morbidity with endocrine diseases associated with negative impacts exerted by environmental factors requires targeted complex scientifically grounded solutions aimed at lowering impacts risks and at creation of new system approaches to prevention of associated endocrine pathology on territories with poor sanitary and hygienic situation.

Primary prevention of endocrine diseases associated with environmental factors on territories where risk of health disorders evolvement in adults and/or children is considered to be unacceptable requires the following actions:

1) to identify basic sources of environment contamination with priority chemicals which endanger population health;

2) to create and stepwise implement activities aimed at lowering emissions (discharges) of hazardous admixtures to levels which make for population health risks becoming acceptable;

3) to adjust programs of ecological and social-hygienic monitoring and industrial surveillance allowing for assessing effectiveness of implemented activities (Figure 1).

On federal level, such approaches imply fixation of health risk parameters as population safety criteria in legal regulations (for example, safety can be determined as unacceptable risk absence in definitions set forth by the Federal Law No.52 dated March 30, 1999 "On sanitary and epidemiologic welfare of the population"1). Introduction of health risk criteria into ecological standardization system is another important step. It means setting standards for permissible emissions and discharges for juridical persons and private entrepreneurs as per health risk criteria. The existing system of permissible emission and discharges standardization is oriented at the mildest hygienic standards which are fixed for only short-term impacts on people; therefore, it doesn't provide full safety of population living under multicomponent chronic exposure. Standardized fixation of risk criteria will require reliable account of danger and threats sources.

It is vital to completely identify and inspect sources of environmental contamination with chemical which are trophic for the endocrine system, first of all, on those territories where endocrine system morbidity is persis-

${ }^{1}$ Collection of the Russian Federation laws. - 1999. - No. 14, p. 1650; 2011; No. 30, p. 4596; 2013, No. 27, p. 3477; No.48, p. 6165. 
tently high; it is also vital for settlements which are enlisted by Federal Service for Hydrometeorology and Environmental Monitoring and social-hygienic monitoring as cities with the highest frequency of such admixtures occurrence. They are Chelyabinsk, Barnaul, Bratsk, Kemerovo, Lesosibirsk, Magnitogorsk,
Novokuznetsk, etc., where, for example, concentrations of aromatic hydrocarbons, benzpyrene, metals, chlorine and its organic compounds reached levels equal to $40 \mathrm{MPC}$ in 2015-2016. An economic entity itself is responsible for such inspections but they can and should be initiated by surveillance authorities.

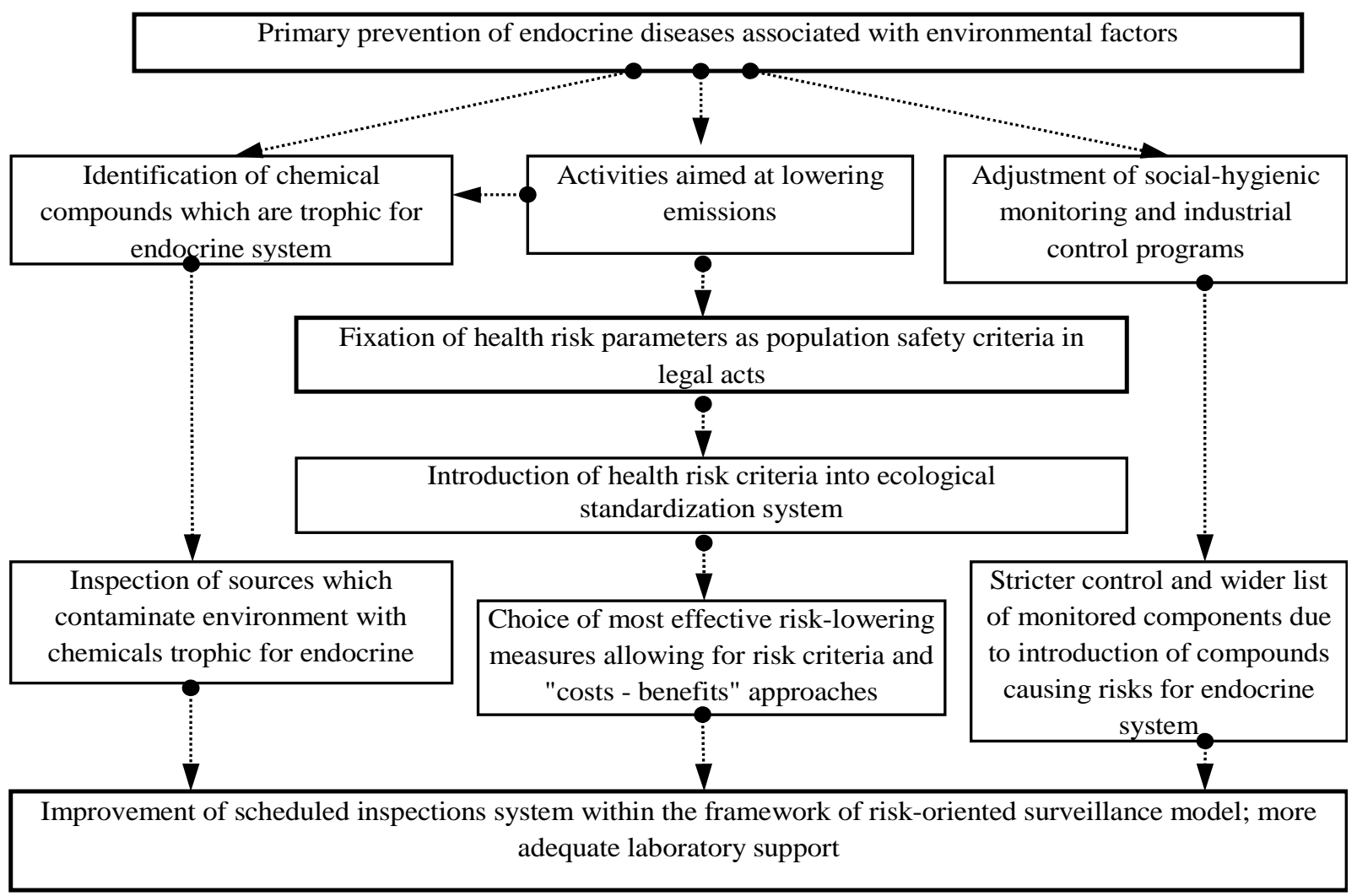

Figure 1. Basic elements in managing risks of endocrine diseases associated with environmental factors in living in areas aimed for development

After risk sources have been detected, creation and stepwise implementation of activities aimed at lowering emissions include several stages: consolidated admixture dispersion (mixing - diluting) calculation $\rightarrow$ integration of calculation results with vector cartographic information which allows to assess influence zones and number of people who are exposed to emissions $\rightarrow$ assessment of share contribution made by various economic entities and determination of contamination levels and health risks $\rightarrow$ choice of most effective measures aimed at lowering emissions allowing for "costs - benefits" approaches $\rightarrow$ implementation of chosen measures. It is this chain of actions which will help to achieve de- sirable results in terms of minimizing threats for population.

But still situation with emissions and discharges is to be permanently monitored by economic entities themselves and surveillance authorities. The latter is provided by systematic observation in social-hygienic monitoring system and here experts observe the level of priority chemical admixtures and endocrine diseases associated with environmental factors on areas aimed for development.

Instrumental examination points within social-hygienic monitoring activities are to be chosen correctly; they are to be located in zones influenced by surveillance objects with these admixtures in their emissions. It will allow to 
view social-hygienic monitoring as a surveillance activity without any direct interaction with juridical persons or private entrepreneurs. Detected violations, if any, can be used as grounds for unscheduled surveillance inspections and/or for applying certain administrative measures.

Scheduled inspection system within riskoriented surveillance model is improved through more adequate laboratory support for such inspections. When inspections take place at objects which have a big share of chemicals trophic for endocrine system in their emissions, discharges, and wastes, laboratory support in such cases can focus on concentrations of most dangerous admixtures in environmental objects (lead, cadmium, manganese, chromium, nickel, benzene, phenol, formaldehyde, benzpyrene in air at the boundary of a sanitary-hygienic zone and in the nearest housing or chloroform and nitrates concentrations in water coming from treatment facilities of water intake stations and distribution networks).

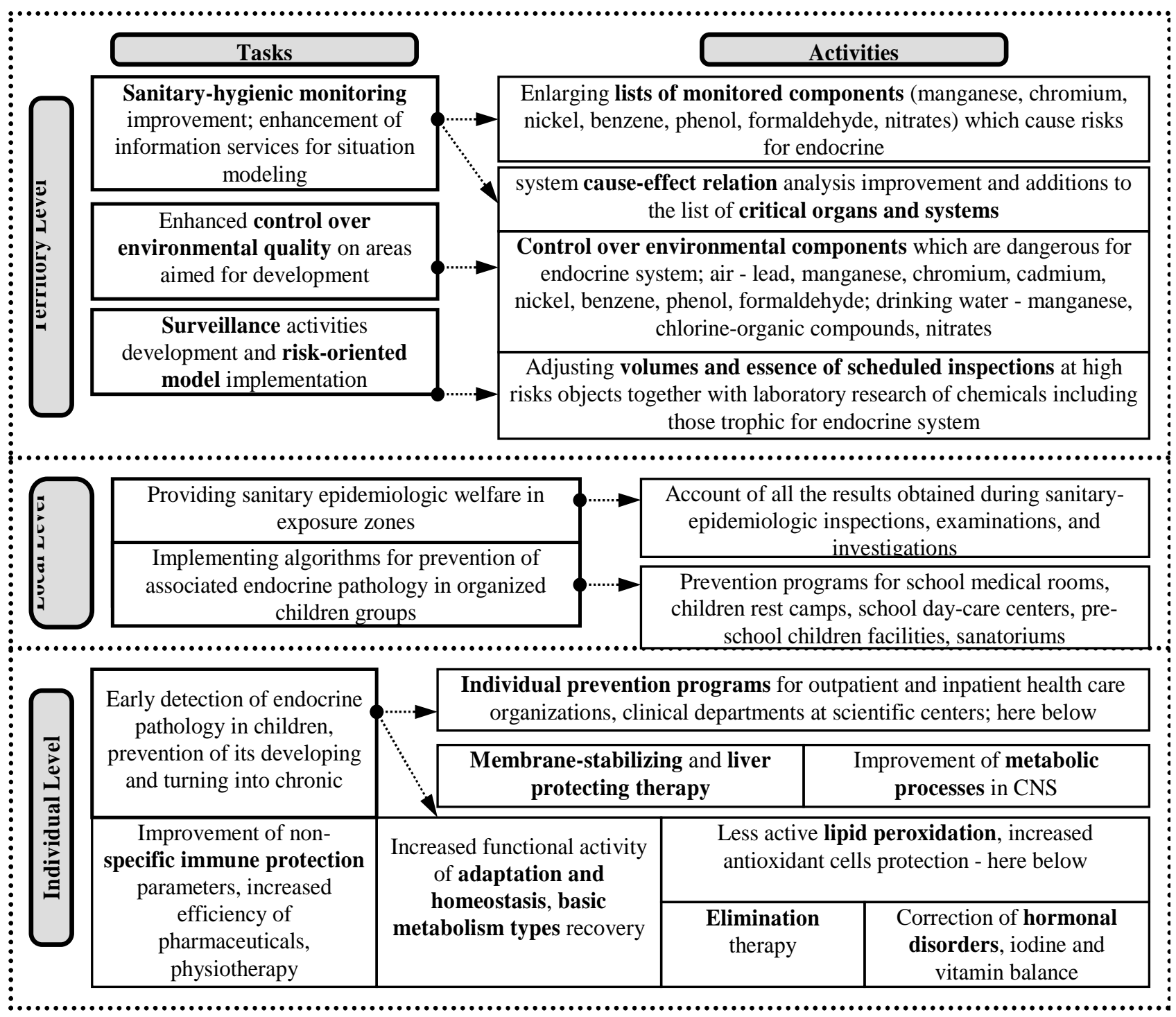

Figure 2. Organizational and functional model for managing risks of endocrine diseases associated with environmental factors in children living on territories aimed for development 
The suggested prevention system is based on social-hygienic monitoring platform which is a united state structure created for observing population health and environment; it includes three levels of preventive activities implementation (Figure 2).

Local level of social-hygienic monitoring improvement means stricter control and wider list of monitored components due to introduction of compounds (manganese, chromium, nickel, benzene, phenol, formaldehyde, and nitrates) which cause risks for endocrine system and other systems which are pathogenetically bound to it.

Improved procedure for determining and analyzing cause-effect relations between impacts exerted by environmental factors and associated endocrine pathology allows for preparation of scientifically grounded standards and sanitary requirements via situational modeling. Risk assessment methodology application implies analyzing correlations in "environment - health" system and it will help to detect reasons and conditions of associated endocrine diseases evolvement in children.

The system allows to structure risks; to assess contribution made by specific trophic factors into total risk; to highlight priorities; to detect areas (zones or districts) with highest health risks; to predict negative or positive changes in population health via analyzing trends in environment quality changes.

Sanitary-hygienic monitoring modernization is hardly possible without conjugation of social-hygienic monitoring system and riskoriented surveillance activity; such conjugation increases analytical capabilities of both systems substantially. Surveillance activity advancement and risk-oriented model implementation implies creating scientific and methodological grounds for account of chemicals trophic for endocrine system. It will necessarily involve adjusting volumes and content of scheduled inspections at high risk objects and laboratory examination of chemicals including those trophic for endocrine system. And here choice of examination points and programs should eventually provide obtaining reliable and convincing results which, notably, indicate:
- threats of causing harm to people's lives and health;

- objects which form threats of causing harm to people's lives and health (if there is such a threat).

Quality parameters of environmental objects which are trophic for endocrine system should be analyzed in dynamics in zones influenced by surveillance objects with various danger categories and we should also analyze changes in children health; it will make for decrease in associated endocrine pathology. We assume it will be possible to detect causeeffect relations within "risk factors - environmental quality - population health" system as per results of social-hygienic monitoring and surveillance activities; it will also help to perform "Rospotrebnadzor activities - environmental quality - population health" conjugated analysis. The suggested approach will allow to assess surveillance activities efficiency as well as to work out certain recommendations for external participants in the process of managing environment and population health, namely, for municipal authorities, enterprises and organization, and civil society.

Sanitary-epidemiologic welfare provision in exposure zones on a local level involves development of a system for proving and registering cases of doing harm to children's lives and health with the use of the results obtained earlier during sanitary-epidemiologic inspections, examinations, and investigations. To solve such a task, social and hygienic monitoring authorities should both perform their basic function of creating a database comprising evidences of cause-effect relation existence in "environment - health" system, and a new one of detecting a source of a threat.

Local level involves prevention activities aimed at early detection of endocrine disorders associated with impacts exerted by chemicals including:

- diagnostics if there are or there are no signs of insufficient nutrition, physical retardation, excessive body mass and obesity, on territories where air and drinking water supply quality is unsatisfactory as per sanitary-chemical 
parameters (manganese, lead, nickel, chromium, cadmium, and chloroform are detected in concentrations higher than 1 MPC) and where there are moderate/high risks of endocrine pathology evolvement in children;

- for children who have signs of physical retardation, excessive or insufficient body mass: chemical and analytical examination of biological media (blood and urine) to detect manganese, lead, chromium, nickel, cadmium, and chloroform concentrations;

- if increased concentrations (more than 1RL) of manganese, lead, nickel, chromium, cadmium, or chloroform, are detected in blood, the following examinations are to be performed: electrocardiography, ultrasonic examination of thyroid gland and gastrointestinal tract, X-ray study of hands, together with a set of laboratory diagnostics including detecting free thyroxin, TSH, IGF-1, hydrocortisone, serotonin, glutamate, and $\gamma$-aminobutyric acid, for children with insufficient nutrition; heart rate assessment, ultrasonic examination of thyroid gland and adrenals, together with a set of laboratory diagnostics including detecting crude cholesterol, LDL, HDL, dextrose, Cpeptide, leptin, free thyroxin, TSH, anti-bodies to thyroid peroxide, hydrocortisone, serotonin, glutamate, and $\gamma$-aminobutyric acid, for children with excessive nutrition and obesity.

If the obtained results correspond to criteria of insufficient nutrition, physical retardation, excessive body mass and obesity associated with impacts exerted by manganese, lead, nickel, chromium, cadmium, and chloroform for more than $80 \%$, specialized medicalpreventive activities are to be organized on individual and group level in children health centers, sanatoriums, and medical rooms at children educational facilities.

Implementation of specialized prevention programs on territories where sanitary and hygienic conditions are unsatisfactory can be based on:

- results of hygienic and medicalbiological studies performed within sanitaryepidemiologic inspections, investigations, and examinations, as well as results of social and hygienic monitoring of environment and popula- tion health including detection of unacceptable risk levels in terms of impacts exerted on population health by environment-polluting chemicals;

- complaints of citizens, private entrepreneurs, juridical persons, state and local authorities, on harm to people's lives and health, as well as on threats of harm to people's lives and health;

- the results of regular medical check-ups of children.

When we give grounds for personified programs aimed at preventing endocrine diseases associated with impacts exerted by chemicals which are trophic for endocrine system, our basic tasks and technology trends are:

- prenosological prevention of associated endocrine pathology which should stimulate greater functional activity of adaptation and homeostasis;

- recurrences prevention, recovery of adaptation and homeostasis functional activity, increase in functional resistance of critical organs and systems;

- diagnostics and prevention of chronic endocrine diseases, pathogenetic correction of adaptation and homeostasis functional activity, recovery of critical organs and systems morphofunctional resistance;

- prevention of complications and disability, correction of pathogenetic mechanisms underlying associated pathology evolvement, correction of enzymatic disorders in cellular and sub-cellular structures of target organs, recovery of basic metabolism types and maintenance of adaptation and homeostasis functional activity.

When we give grounds for personified technologies for endocrine diseases prevention (nutrition disorders, physical retardation, and obesity, associated with impacts exerted by chemicals which are trophic for endocrine system), our choice on individual programs is determined not only by their capability to promptly eliminate priority compounds which form total individual chemical load, but also by possibility to correct basic pathophysiological and pathomorphologic disorders in target organs. Here we can mention improvement in neuro-vegetative regulation, functional and 
metabolic processes in CNS (including nootropic, antiaggregant, and antioxidant effects of hopantenic and $\gamma$-aminobutyric drugs); membrane-stabilizing and liver-protecting technologies (with the use of phospholipids, glycyrrhizin acid, and phytocholeretics); basic metabolic types normalization, oxidative and antioxidant processes balance (less active lipid peroxidation, higher cells antioxidant protection, acid-base balance recovery on system, cellular, and sub-cellular levels); stimulation of immunologic protection and non-specific reactivity factors; recovery of organs and systems adaptation reserves and hormonal homeostasis; improvement in membrane-cellular and organ mechanisms for biological transformation and elimination of chemicals and their metabolites (sorptive technologies with the use of polydimethylsiloxane, polyhydrate, lignin, and lactulose).

Early detection and prophylaxis of associated endocrine pathology in children makes for prevention of its developing and becoming chronic; it allows to decrease mediated pathology in adults (obesity, pancreatic diabetes, and primary hypertension).

So, we suggest methodological approaches which will help to efficiently manage risks of endocrine diseases associated with impacts by environmental factors evolvement in children living on territories aimed for development. Such approaches are based on system combination of activities on various management levels in improvement of risk-oriented surveillance model, on account of detected trophic risk factors in regional social-hygienic monitoring programs, on implementation of dynamic observation over exposed children, and on up-to-date preventive technologies.

The suggested organizational-functional model for managing risks of endocrine diseases associated with impacts by environmental factors evolvement in children living on territories aimed for development was tested in 4 RF regions. It appeared to be highly efficient and economically justified. The priority territories included those with most unfavorable sanitaryhygienic parameters of air as per lead, manganese, nickel, chromium, and cadmium content (Kirovskiy district of Perm and Kungur), and of water in terms of chlorine organic compounds contents (Krasnokamsk and Nytva), nitrates contents (Sylva settlement), benzene, phenol, formaldehyde, and benzpyrene contents (Nizhniy Tagil in Yekaterinburg region).

\section{References}

1. Doklad o sostoyanii zdorov'ya naseleniya i organizatsii zdravookhraneniya po itogam deyatel'nosti organov ispolnitel'noi vlasti sub"ektov Rossiiskoi Federatsii za 2014 god: Gosudarstvennyi doklad [Report on population health and public healthcare organization as per results of activities by executive power bodies in the RF subjects over 2014: State Report]. Moscow, Ministerstvo zdravookhraneniya Rossiiskoi Federatsii Publ., 2015, 161 p. (in Russian).

2. Zhavoronok L.G. Sotsial'no-gigienicheskii monitoring - instrument upravleniya kachestvom sredy obitaniya i zdorov'ya naseleniya [Social-hygienic monitoring as a tool for managing environment quality and population health]. Uchenye zapiski Rossiiskogo gosudarstvennogo sotsial'nogo universiteta, 2009, no. 5, pp. 124-129 (in Russian).

3. Zabolevaemost' vsego naseleniya Rossii v 2014 godu: Statisticheskie materialy [Total Russian population morbidity in 2014: Statistic data]. Moscow, Tsentral'nogo nauchno-issledovatel'skogo instituta organizatsii i informatizatsii zdravookhraneniya Ministerstva zdravookhraneniya RF Publ., 2015, part $1,138 \mathrm{p}$.

4. Zaitseva N.V., May I.V., Kiryanov D.A., Sboev A.S., Andreeva E.E. Kontseptual'nye i metodicheskie aspekty povysheniya effektivnosti kontrol'no-nadzornoi deyatel'nosti na osnove otsenki opasnosti ob"ekta s pozitsii riska prichineniya vreda zdorov'yu naseleniya [Conceptual and methodological aspects of improving the effectiveness of control and supervisory activities based on hazard and risk assessment and estimation of harm to health of the population]. Zdorov'e naseleniya i sreda obitaniya, 2014, vol. 261, no. 12, pp. $4-7$ (in Russian). 
5. Luzhetskiy K.P. Ioddefitsitnye zabolevaniya prirodno-obuslovlennogo proiskhozhdeniya u detei Permskogo kraya [Iodine the scarce diseases of the prirodno-technogenic origin at children of the Perm region]. Zdorov'e naseleniya i sreda obitaniya, 2010, no. 3, pp. 25-29 (in Russian).

6. Luzhetskiy K.P., Ustinova O.Yu., Palagina L.N. Strukturno-dinamicheskii analiz endokrinnoi patologii u detei, prozhivayushchikh $\mathrm{v}$ usloviyakh vozdeistviya khimicheskikh tekhnogennykh faktorov sredy obitaniya (na primere Permskogo kraya) [Structural dynamic analysis endocrine disorders in children living in conditions of man-made chemicals environmental factors]. Zdorov'e naseleniya $i$ sreda obitaniya, 2013, vol. 248, no. 11, pp. 32-35 (in Russian).

7. Popova A.Yu., Zaitseva N.V., May I.V., Kiryanov D.A. O razvitii sistemy risk-orientirovannogo nadzora $\mathrm{v}$ oblasti obespecheniya sanitarno-epidemiologicheskogo blagopoluchiya naseleniya i zashchity prav potrebitelei [On the development of the system of risk-based supervision in the field of sanitary and epidemiological welfare of the population and consumer protection]. Analiz riska zdorov'yu, 2015, no. 4, pp. 4-12 (in Russian).

8. O sostoyanii sanitarno-epidemiologicheskogo blagopoluchiya naseleniya v Rossiiskoi Federatsii v 2015 godu: Gosudarstvennyi doklad [On sanitary-epidemiologic wellbeing of the population in the RF in 2015: State Report]. Moscow, Federal'naya sluzhba po nadzoru v sfere zashchity prav potrebitelei i blagopoluchiya cheloveka Publ., 2016, 206 p. (in Russian).

9. Onishchenko G.G. Vliyanie sostoyaniya okruzhayushchei sredy na zdorov'e naseleniya. Nereshennye problemy i zadachi [Environmental influences on human health: Unsolved problems and tasks]. Gigiena $i$ sanitariya, 2003, no. 1, pp. 3-10 (in Russian).

10. Speranskaya O., Sergeev O. Veshchestva narushayushchie rabotu endokrinnoi sistemy: sostoyanie problemy i vozmozhnye napravleniya raboty [Compounds causing disorders in endocrine system functioning: existing problems and possible lines of activities]. Samara, Izdatel'stvo As Gard Publ., 2014, 35 p. (in Russian).

11. Tulyakova O.V., Avdeeva M.S. Vliyanie aerotekhnogennogo zagryazneniya na fizicheskoe razvitie, dvigatel'nye kachestva i navyki pervoklassnikov [Influence of air pollution on physical development, moving qualities and skills of the first-year pupils]. Sibirskii meditsinskii zhurnal, 2012, vol. 110, no. 3, pp. 116-118 (in Russian).

12. Khamidulina Kh.Kh., Dorofeeva E.V. Endokrinnye razrushiteli - problema naseleniya Zemli v 21 veke [Endocrine disruptors. Present status of the problem]. Toksikologicheskii vestnik, 2013, vol. 2019 no. 2, pp. 51-54 (in Russian).

13. Chernyak I.Yu., Shashel' V.A. Epidemiologicheskie i ekologicheskie pokazateli sakharnogo diabeta 1 tipa u detei i podrostkov Krasnodarskogo kraya [Epidemiology and ecology of type 1 diabetes mellitus in children and adolescents of Krasnodar Region]. Sakharnyi diabet, 2013, no. 3, pp. 30-34 (in Russian).

14. Yaglova N.V., Yaglov V.V. Endokrinnye razrushiteli - novoe napravlenie issledovanii v endokrinologii [Endocrine disruptors are a novel direction of endocrinologic scientific investigation]. Vestnik Rossiiskoi akademii meditsinskikh nauk, 2012, no. 3, pp. 56-61 (in Russian).

15. Chemical Exposures During Pregnancy: Dealing with Potential, but Unproven, Risks to Child Health: Scientific Impact Paper 37. Royal College of Obstetricians and Gynaecologists, 2013, 7 p.

16. Gore A.C., Chappell V.A., Fenton S.E., Flaws J.A., Nadal A., Prins G.S., Toppari J., Zoeller R.T. EDC-2: The Endocrine Society's Second Scientific Statement on Endocrine-Disrupting Chemicals. Endocr Rev, 2015, vol. 36, no. 6, pp. E1-E150. DOI: 10.1210/er.2015-1010.

17. Zoeller R.T., Brown T.R., Doan L.L., Gore A.C., Skakkebaek N.E., Soto A.M., Woodruff T.J., Vom Saal F.S. Endocrine- Disrupting Chemicals and Public Health Protection: A Statement of Principles from The Endocrine Society. Endocrinology, 2012, vol. 153, no. 9, pp. 4097-4110. DOI: 10.1210/en.2012-1422.

18. Diamanti-Kandarakis E., Bourguignon J.P., Giudice L.C., Hauser R., Prins G.S., Soto A.M., Zoeller R.T., Gore A.C. Endocrine-disrupting chemicals: An endocrine society scientificstatement. Endocrine Reviews, 2009, vol. 30, no. 4, pp. 293-342. DOI: 10.1210/er.2009-0002.

19. Exposure to Toxic Environmental Agents. The American College of Obstetricians and Gynecologists, Washington, 2013, 17 p. 
20. Bergman Å., Heindel J.J., Jobling S., Kidd K.A., Zoeller R.T. The State of the Science of Endocrine Disrupting Chemicals - 2012. Geneva: World Health Organization / United Nations Environment Programme, 2013, 296 p.

Luzhetskiy K.P. Methodical approaches to managing risks for endocrine diseases evolvement in children related to impacts of environmental factors occuring on areas aimed for development. Health Risk Analysis, 2017, no. 2, pp. 45-53. DOI: 10.21668/health.risk/2017.2.05.eng

Received: 05.02.2017

Accepted: 20.05 .2017

Published: 30.06.2017 
UDC 614.72: 616

DOI: 10.21668/health.risk/2017.2.06.eng

\title{
ASSESSMENT OF CARCINOGENIC HEALTH RISK FOR POPULATION LIVING IN MONOCITIES AND RURAL SETTELEMENTS
}

\author{
V.M. Boev, D.A. Kryazhev, L.M. Tulina, A.A. Neplokhov \\ Orenburg State Medical University, 6 Sovetskaya Str., Orenburg, 460000, Russian Federation
}

Our research goal was to perform assessment of carcinogenic health risk for population living in monocities and rural settlements in Orenburg region including both total and individual carcinogenic risk assessment. We assessed carcinogenic health risks for population living in cities with industrial enterprises as economic bases (Novotroitsk and Mednogorsk) and rural settlements (Oktyabrskiy, Ilekskiy, and Tyul'ganskiy districts) in Orenburg region. Exposure assessment was based on the data obtained via laboratory research of environmental objects over 2005-2013 (1,265 atmospheric air samples and 1,897 drinking water samples). We determined total carcinogenic risks for population on each territory under multi-environment impacts exerted by chemicals; a share of each chemical in risk formation was also identified. The results we obtained allow us to make a conclusion that monocities' areas are unfavorable in terms of carcinogenic effects on population health. We detected priority carcinogens for each territory in order to work out practical recommendations on lowering carcinogenic risks and on possibility of delayed effects evolvement. Carcinogenic risk caused by chemicals contained in drinking water both in monocities and rural settlements was considered to be acceptable; however, it was 1.5-2 times higher for monocities population. Overall, chromium took the leading role among carcinogens in monocities air; benzene and arsenic occupied the same place in rural settlements air. Chromium, benzpyrene, and arsenic were priority carcinogens contained in drinking water in rural settlements. Our research proves the necessity to work our practical recommendations on lowering carcinogenic risks and on possibility of delayed effects evolvement on regional level.

Key words: total carcinogenic risk, individual carcinogenic risk, multi-environment impact, chemicals, environmental factors.

In contemporary context, public health depends greatly upon actual assurance of rights to a safe living environment and prevention of diseases. According to the World Health Organization (WHO), the highest contribution to population health is made by a group of factors consolidated by the concept of "external environment", which includes numerous elements that pollute air, water, soil, food [7-9, 15].

In recent decades, high prevalence of malignant neoplasms is a challenging issue for the population of Orenburg region, especially for the population in monocities $[1,2,11]$.
Studying the effects of environmental factors on population health is one of the central focuses among other challenges in environmental hygiene. Medical significance of this issue is determined by the need for timely prevention of negative changes in health status associated with the action of environmental factors, their timely correction, which is the basis for primary prevention of diseases [12].

According to $\mathrm{WHO}$, air pollution is the most important specific environmental health risk factor in the European Region [14, 15]. Particular attention should be paid to assessment and prevention of the delayed effects of

(C) Boev V.M., Kryazhev D.A., Tulina L.M., Neplokhov A.A., 2017

Viktor M. Boev - Doctor of Medical Sciences, Professor, Head of Common and Communal Hygiene Department (e-mail: kafedragigiena@ mail.ru; tel.: +7 (3532) 77-71-26).

Dmitriy A. Kryazhev - Candidate of Medical Sciences, senior teacher at Common and Communal Hygiene Department (e-mail: mitya_k87@ mail.ru; tel.: +7 (3532) 77-71-26).

Larisa M. Tulina - Candidate of Medical Sciences, Associate Professor at Common and Communal Hygiene Department (e-mail: k_com.gig@orgma.ru; tel.: +7 (3532) 77-71-26).

Andrey A. Neplokhov - Candidate of Medical Sciences, Associate Professor at Common and Communal Hygiene Department (e-mail: k_com.gig@orgma.ru; tel.: +7 (3532) 77-71-26). 
pollutants on public health data [8]. When assessing risks their complex and combined routes of exposure must be taken into account.

In prevention of delayed effects, assessment of carcinogenic health risk is still very important, which in turn allows early identification of risk factors and working out a package of measures for their elimination. At the same time, a differentiated approach should be considered, with priority risk factors identified for each territory $[3,4,13]$.

Risk assessment activities open up new opportunities to analyze multi-environment impacts and integrated chemicals intake with maximum consideration to the multiple sources, routes and ways of influence, different spectra of emerging effects.

Among the industrial cities of the region, the largest total carcinogenic risk from exposure to atmospheric air pollution was registered in Novotroitsk, then in Orsk, Mednogorsk and Orenburg. The highest share to carcinogenic effects risk in Mednogorsk, Novotroitsk and Orsk is made by the content of chromium oxide $(+6)$ in atmospheric air (share in the total risk of 87,82 and $69 \%$ respectively). In Orenburg, the largest share (57\%) is made by benzene content in the atmospheric air [5]. Sanitary and hygienic rating for the Orenburg region territory in terms of total carcinogenic risk for 2015 showed the highest risk levels exceeding the acceptable ones (1.0E-10-4 - 1.0E-10-6) on 27 territories of the region: in Abdulino, Ponomarevo, Saraktash, Tyul'ganskiy, Oktyabrskiy, Ilekskiy, Matveyevskiy, Aleksandrovskiy, Perevolotskiy, Kuvandykskiy, Belyaevskiy, Tashlinskiy, Sorochinskiy, Krasnogvardeyskiy, Gay, Novoorsk, Novosergievskiy, Sakmara, Adamovskiy, Kvarkenskiy, Yasnenskiy districts, Orenburg city, as well as in Svetlinskoye, Sharlykskiy, Grachevskiy, Orenburgskiy, Pervomaiskiy areas [5]. It should be noted that in the large industrial cities (Orenburg, Orsk), there is a tendency to reducing risk, while in monocities (Mednogorsk, Novotroitsk), there is an increase in carcinogenic and noncarcinogenic risks to the population health.

The earlier comparative reviews on risk assessment in monocities and rural settlements of Orenburg region argue for the urgency of the problem.

Given the wide prevalence of carcinogens in environmental objects, an assessment of their complex impact is of particular interest.

Materials and methods. In order to identify the degree of exposure to pollutants contained in atmospheric air and drinking water, being carcinogenic to humans according to the classification of the International Agency for Research on Cancer (IARC), we assessed carcinogenic health risks for population living in cities with industrial enterprises as economic bases (Novotroitsk, Mednogorsk), and rural settlements (Oktyabrskiy, Ilekskiy and Tyul'ganskiy districts). The assessment of carcinogenic risks to public health was carried out in compliance with the "Guidelines for assessment of public health risk from exposure to chemicals that pollute habitat" $[4,6,10]$. We studied the laboratory reports on environmental objects for the last 5 years. A total of 1,245 samples of atmospheric air and 1,897 samples of drinking water were analyzed.

We studied data of the Regional Information Fund for Socio-Hygienic Monitoring at the FBHI "Center for Hygiene and Epidemiology in Orenburg region", official statistical data forms of territorial body of the Federal State Statistics Service for Orenburg region, and data of the FGA "Orenburg Center for Hydrometeorology and Environmental Monitoring" for 2005-2013. Among the atmospheric air components studied at the fixed stations of "Orenburg Center for Hydrometeorology and Environmental Monitoring" (branch of FSBI "Hydrometeorology and Environmental Monitoring for Volga Region"), 8 pollutants (formaldehyde, benzo (a) pyrene, benzene, ethylbenzene, lead, chromium oxide (+6), nickel and cadmium) have carcinogenic properties; 15 carcinogens (benzo (a) pyrene, benzene, arsenic, nickel, lead, chrome, 2,4-D, chloroform, carbon tetrachloride, 1,2dichloroethane, tetrachlorethylene, bromide dichloromethane, dibromochloromethane, bromoform, and trichlorethylene) were detected in drinking water. When assessing exposure, we used incidence factors of substances' 
concentrations in various media. In the atmospheric air (29,440 samples) and the drinking water from the centralized water supply systems (6,521 samples), we assessed mean concentrations of substances subject to a longterm dynamic surveillance within the framework of socio-hygienic monitoring.

Results and discussion. When identifying hazard, it was found that the major origins of environmental pollution in Novotroitsk were the large enterprises of metallurgical industry, construction and food industries (LLC "Novotroitsk Construction Materials Plant "Argo", JSC "Ural Steel", JSC "Cement Plant", JSC "Novotroitsk Silicate Materials Plant", JSC "Novotroitsk Chromium Compounds Plant", LLC "Novotroitsk Meat Processing Plant", Novotroitsk Branch of OJSC "Uralelektroremont Concern", JSC "Novotroitsk Bread Products Plant", LLC "Moloko"). In the city of Mednogorsk, the main origins of pollution are JSC "Mednogorsk Copper and Sulfur Plant", JSC "Mednogorsk Elektrotechnical Plant "Uralelektro", cogeneration plant of Mednogorsk and LLC "Mednogorsk Brick Plant".

In the rural settlements territory, the main origins of environmental pollution are road transport, heat power and food industry enterprises, and agricultural companies.

Mednogorsk is located on the territory of 0.4 thousand $\mathrm{km}^{2}$, the population for the period under study: 29.78 thousand people. Persons who have not reached working age make up $25 \%$ of the population, $60 \%$ are persons of working age and $15 \%$ - are over working age.

The area of Novotroitsk is 0.4 th. $\mathrm{km} 2$, the population is 100.94 thousand people. According to the review of the population structure, $21 \%$ are older than the working age, $64 \%$ are in the working age, and $15 \%$ of the population - are under the working age.

Ilekskiy district has an area of 3.6 th. $\mathrm{km} 2$, the average population: 23.89 thousand people. When studying the population structure, it was found that $23 \%$ were people under the working age, $52 \%$ were of the working age, $25 \%$ - older the working age.
Oktyabrskiy and Tyul'ganskiy districts occupy an area of 2.7 and 1.9 thousand $\mathrm{km} 2$, respectively. The population for the period under study made 22.59 and 23.46 thousand people, respectively.

Data analysis on carcinogens found in the atmospheric air of Mednogorsk showed that the highest individual carcinogenic risks are made by chromium compounds $(2.8 \times 10-3$, share in the total carcinogenic risk $35.3 \%$ ). The total life-long carcinogenic risk as a result of exposure to air pollutants is $3.31 \times 10-3$, which is considered as unacceptable (Table 1).

In Novotroitsk, the highest individual carcinogenic risk was established for chromium (4.31 x 10-3, 92.7\%). For Novotroitsk, the total carcinogenic risk from carcinogens contained in the atmospheric air makes $4.65 \times 10$ 3 , which is regarded as unacceptable carcinogenic risk (see Table 1).

The carcinogenic effect assessment for Oktyabrskiy district showed that the highest individual carcinogens risk in the atmospheric air was of chrome $(6.2 \times 10-4,46 \%)$ and arsenic $(6.1 \times 10-4,45 \%)$, which made $91 \%$ of the total carcinogenic risk equaling to $1.35 \times 10-3$ (Table 2).

In Ilekskiy district, the maximum share $(82 \%)$ to the total carcinogenic risk accounts for chromium (ICR $4.15 \times 10-3$ ). The total carcinogenic risk made $5.1 \times 10-3$, which is evaluated as the unacceptable carcinogenic risk.

The highest individual carcinogenic risk from substances in the atmospheric air in Oktyabrskiy district was established for arsenic $(1.3 \times 10-3,78.5 \%)$. The second rank was for benzene $(1.4 \times 10-4,9 \%)$. The total carcinogenic risk for Oktyabrskiy district made $1.6 \mathrm{x}$ 10-3.

Analysis of carcinogenic risk from exposure to chemicals contained in drinking water showed that the maximum individual carcinogenic risk for the city of Mednogorsk was established for arsenic $(3.8 \times 10-4,59.1 \%)$ and chromium $(2.2 \% 10-4,33.5 \%)$. The total carcinogenic risk from chemicals contained in drinking water for Mednogorsk made $6.44 \mathrm{x}$ 10-4 (Table 3). 
Table 1

Life-long carcinogenic risk from exposure to chemicals in ambient air

\begin{tabular}{|l|c|c|c|c|}
\hline \multirow{2}{*}{\multicolumn{1}{|c|}{ Chemical Substance }} & \multicolumn{2}{c|}{ Mednogorsk city } & \multicolumn{2}{c|}{ Novoroitsk city } \\
\cline { 2 - 5 } & \multicolumn{1}{|c|}{$I C R$} & Share, $\%$ & $I C R$ & Share, $\%$ \\
\hline Formaldehyde & $1,15 \mathrm{E}-04$ & 14,5 & $1,35 \mathrm{E}-04$ & 2,90 \\
\hline Benz (a) pyrene & $3,65 \mathrm{E}-07$ & 0,0 & $1,58 \mathrm{E}-07$ & 0,00 \\
\hline Benzene & $1,14 \mathrm{E}-04$ & 14,4 & $1,26 \mathrm{E}-05$ & 0,27 \\
\hline Ethylbenzene & $4,59 \mathrm{E}-06$ & 0,6 & $3,85 \mathrm{E}-06$ & 0,08 \\
\hline Styrene & $1,55 \mathrm{E}-06$ & 0,2 & $2,68 \mathrm{E}-06$ & 0,06 \\
\hline Chromium & $2,8 \mathrm{E}-03$ & 35,3 & $4,31 \mathrm{E}-03$ & 92,71 \\
\hline Lead & $9,56 \mathrm{E}-07$ & 0,1 & 0 & 0,00 \\
\hline Arsenic & $1,04 \mathrm{E}-04$ & 13,3 & 0 & 0,00 \\
\hline Soot & $7,38 \mathrm{E}-05$ & 9,3 & $1,74 \mathrm{E}-04$ & 3,74 \\
\hline Nickel & $1,34 \mathrm{E}-05$ & 1,7 & 0 & 0,00 \\
\hline Cobalt & $5,22 \mathrm{E}-05$ & 6,6 & 0 & 0,00 \\
\hline Cadmium & $2,00 \mathrm{E}-05$ & 2,5 & 0 & 0,00 \\
\hline Chloroform & $3,10 \mathrm{E}-06$ & 0,4 & $8,00 \mathrm{E}-08$ & 0,00 \\
\hline Carbon tetrachloride & $8,44 \mathrm{E}-06$ & 1,1 & $1,03 \mathrm{E}-05$ & 0,22 \\
\hline Total risk & $\mathbf{3 , 3 1 E - 0 3}$ & & $\mathbf{4 , 6 5 E}-03$ & \\
\hline
\end{tabular}

Table 2

Life-long carcinogenic risk from exposure to chemicals in ambient air

\begin{tabular}{|c|c|c|c|c|c|c|}
\hline \multirow{2}{*}{ Chemical Substance } & \multicolumn{2}{|c|}{ Tyul'gansky district } & \multicolumn{2}{|c|}{ Ilekskiy district } & \multicolumn{2}{|c|}{ Oktyabrskiy district } \\
\hline & $I C R$ & Share, \% & $I C R$ & Share, $\%$ & $I C R$ & Share, $\%$ \\
\hline Formaldehyde & $3,55 \mathrm{E}-05$ & 2,63 & $9,05 \mathrm{E}-05$ & 1,78 & $3,26 \mathrm{E}-05$ & 2,04 \\
\hline Benz (a) pyrene & $1 \mathrm{E}-07$ & 0,01 & $4,46 \mathrm{E}-07$ & 0,01 & $8,25 \mathrm{E}-08$ & 0,01 \\
\hline Benzene & $3,46 \mathrm{E}-06$ & 0,26 & $7,12 \mathrm{E}-04$ & 14,04 & 0,00014 & 8,74 \\
\hline Ethylbenzene & $3,34 \mathrm{E}-07$ & 0,02 & 0 & 0,00 & $2,24 \mathrm{E}-06$ & 0,14 \\
\hline Styrene & $3,96 \mathrm{E}-07$ & 0,03 & 0 & 0,00 & $3,89 \mathrm{E}-07$ & 0,02 \\
\hline Chromium & $6,2 \mathrm{E}-04$ & 45,94 & $4,146 \mathrm{E}-03$ & 81,7 & $1,87 \mathrm{E}-05$ & 1,17 \\
\hline Lead & $1,72 \mathrm{E}-07$ & 0,01 & $1,89 \mathrm{E}-06$ & 0,04 & $1,89 \mathrm{E}-06$ & 0,12 \\
\hline Arsenic & $6,13 \mathrm{E}-04$ & 45,39 & 0 & 0,00 & $1,3 \mathrm{E}-03$ & 78,46 \\
\hline Soot & $1,95 \mathrm{E}-05$ & 1,45 & 0 & 0,00 & $2,91 \mathrm{E}-05$ & 1,82 \\
\hline Nickel & $4,07 \mathrm{E}-05$ & 3,02 & $2,84 \mathrm{E}-06$ & 0,06 & $2,43 \mathrm{E}-06$ & 0,15 \\
\hline Cobalt & $4,87 \mathrm{E}-06$ & 0,36 & $2,67 \mathrm{E}-05$ & 0,53 & $8,88 \mathrm{E}-05$ & 5,55 \\
\hline Cadmium & $2,66 \mathrm{E}-06$ & 0,20 & $9,23 \mathrm{E}-05$ & 1,8 & 0,000012 & 0,75 \\
\hline Chloroform & $5,67 \mathrm{E}-06$ & 0,42 & 0 & 0,00 & $2,12 \mathrm{E}-06$ & 0,13 \\
\hline Carbon tetrachloride & $3,61 \mathrm{E}-06$ & 0,27 & 0 & 0,00 & $1,44 \mathrm{E}-05$ & 0,90 \\
\hline Total risk & 1,35E-03 & & 5,1E-03 & & $1,6 \mathrm{E}-03$ & \\
\hline
\end{tabular}

Table 3

Carcinogenic risk from exposure to chemicals in drinking water

\begin{tabular}{|l|c|c|c|c|}
\hline \multirow{2}{*}{\multicolumn{1}{c|}{ Chemical Substance }} & \multicolumn{2}{c|}{ Mednogorsk city } & \multicolumn{2}{c|}{ Novoroitsk city } \\
\cline { 2 - 5 } & $I C R$ & Share, $\%$ & $I C R$ & Share, $\%$ \\
\hline Arsenic & $3,8 \mathrm{E}-04$ & 59,1 & $2,14 \mathrm{E}-04$ & 61,85 \\
\hline Lead & $4,32 \mathrm{E}-06$ & 0,67 & $2,39 \mathrm{E}-06$ & 0,69 \\
\hline Chromium & $2,16 \mathrm{E}-04$ & 33,5 & $1,2 \mathrm{E}-04$ & 34,6 \\
\hline Beryllium & 0 & 0,00 & 0 & 0,00 \\
\hline Cadmium & 0 & 0,00 & 0 & 0,00 \\
\hline $2.4 \mathrm{D}$ & $8,686 \mathrm{E}-07$ & 0,13 & 0 & 0,00 \\
\hline Benz (a) pyrene & $9,91 \mathrm{E}-06$ & 1,54 & 0 & 0,00 \\
\hline Benzol & $8,486 \mathrm{E}-06$ & 1,32 & 0 & 0,00 \\
\hline Chloroform & $2,242 \mathrm{E}-07$ & 0,03 & $2,28 \mathrm{E}-06$ & 0,66 \\
\hline
\end{tabular}


End of Table 3

\begin{tabular}{|l|c|c|c|c|}
\hline \multirow{2}{*}{ Chemical Substance } & \multicolumn{2}{c|}{ Mednogorsk city } & \multicolumn{2}{c|}{ Novoroitsk city } \\
\cline { 2 - 5 } & $I C R$ & Share, $\%$ & $I C R$ & Share, $\%$ \\
\hline Carbon tetrachloride & $1,931 \mathrm{E}-06$ & 0,30 & $3,87 \mathrm{E}-06$ & 1,12 \\
\hline 1,2-Dichloroethane & $1,04 \mathrm{E}-05$ & 1,62 & 0 & 0,00 \\
\hline Tetrachlorethylene & $9,509 \mathrm{E}-07$ & 0,15 & 0 & 0,00 \\
\hline Bromodichloromethane & $2,645 \mathrm{E}-06$ & 0,41 & $2,42 \mathrm{E}-06$ & 0,70 \\
\hline Dibromochloromethane & $6,56 \mathrm{E}-06$ & 1,02 & $1,09 \mathrm{E}-06$ & 0,31 \\
\hline Bromoform & $2,483 \mathrm{E}-07$ & 0,04 & $1,08 \mathrm{E}-07$ & 0,03 \\
\hline Ethinyl trichloride & $4,086 \mathrm{E}-07$ & 0,06 & $7,14 \mathrm{E}-09$ & 0,00 \\
\hline DDT & $9,714 \mathrm{E}-07$ & 0,15 & 0 & 0,00 \\
\hline Total risk & $\mathbf{6 , 4 4 E - 0 4}$ & & $\mathbf{3 , 4 6 E - 0 4}$ & \\
\hline
\end{tabular}

Table 4

Carcinogenic risk from exposure to chemicals in drinking water

\begin{tabular}{|l|c|c|c|c|c|c|}
\hline \multirow{2}{*}{ Chemical Substance } & \multicolumn{2}{|c|}{ Ilekskiy district } & \multicolumn{2}{c|}{ Oktyabrskiy district } & \multicolumn{2}{c|}{ Tyul'gansky district } \\
\cline { 2 - 7 } & $I C R$ & Share, $\%$ & $I C R$ & Share, $\%$ & $I C R$ & Share, $\%$ \\
\hline Arsenic & $2,11 \mathrm{E}-04$ & 35,4 & $8,16 \mathrm{E}-05$ & 36,6 & $1,34 \mathrm{E}-04$ & 72 \\
\hline Lead & $4,05 \mathrm{E}-07$ & 0,07 & 0 & 0 & $2,84 \mathrm{E}-06$ & 1,5 \\
\hline Chromium & $1,58 \mathrm{E}-04$ & 26,5 & $4,8 \mathrm{E}-05$ & 21,5 & $1,91 \mathrm{E}-05$ & 10,3 \\
\hline Beryllium & $2,46 \mathrm{E}-05$ & 4,1 & $3,93 \mathrm{E}-06$ & 1,76 & $8,49 \mathrm{E}-06$ & 4,56 \\
\hline Cadmium & $9,46 \mathrm{E}-06$ & 1,6 & $2,93 \mathrm{E}-05$ & 13,2 & $9,05 \mathrm{E}-07$ & 0,49 \\
\hline 2.4 D & $1,04 \mathrm{E}-06$ & 0,18 & $1,65 \mathrm{E}-07$ & 0,07 & 0 & 0 \\
\hline Benz (a) pyrene & $1,74 \mathrm{E}-04$ & 29,2 & $4,92 \mathrm{E}-05$ & 22,1 & $1,49 \mathrm{E}-05$ & 8 \\
\hline Benzol & 0 & 0 & $4,62 \mathrm{E}-07$ & 0,21 & 0 & 0 \\
\hline Chloroform & $9,3 \mathrm{E}-08$ & 0,016 & $7,94 \mathrm{E}-08$ & 0,036 & $3,49 \mathrm{E}-08$ & 0,019 \\
\hline Carbon tetrachloride & $1,98 \mathrm{E}-06$ & 0,33 & $1 \mathrm{E}-06$ & 0,45 & $2,79 \mathrm{E}-07$ & 0,15 \\
\hline 1,2-Dichloroethane & $1,16 \mathrm{E}-05$ & 1,9 & $5,85 \mathrm{E}-06$ & 2,6 & $1,63 \mathrm{E}-06$ & 0,87 \\
\hline Tetrachlorethylene & 0 & 0 & $5,46 \mathrm{E}-07$ & 0,25 & $3,4 \mathrm{E}-06$ & 1,8 \\
\hline Bromodichloromethane & $1,26 \mathrm{E}-06$ & 0,21 & $6,38 \mathrm{E}-07$ & 0,29 & $1,77 \mathrm{E}-07$ & 0,095 \\
\hline Dibromochloromethane & $2,13 \mathrm{E}-06$ & 0,36 & $1,08 \mathrm{E}-06$ & 0,48 & $3 \mathrm{E}-07$ & 0,16 \\
\hline Bromoform & $2,01 \mathrm{E}-07$ & 0,034 & $1,02 \mathrm{E}-07$ & 0,046 & $2,82 \mathrm{E}-08$ & 0,015 \\
\hline Ethinyl trichloride & $4,19 \mathrm{E}-07$ & 0,07 & $2,04 \mathrm{E}-07$ & 0,09 & 0 & 0 \\
\hline DDT & 0 & 0 & $6,94 \mathrm{E}-07$ & 0,31 & 0 & 0 \\
\hline Total risk & $\mathbf{5 , 9 5 E - 0 4}$ & & $\mathbf{2 , 2 3 E - 0 4}$ & & $\mathbf{1 , 8 6 E}-04$ & \\
\hline
\end{tabular}

When assessing the carcinogenic risk in Novoroitsk, it was found that the highest individual carcinogenic risk was in arsenic $(2.14 \mathrm{x}$ $10-4,61.9 \%)$ and chromium (1.2 x 10-4, $34.6 \%)$.

The total carcinogenic risk in Novotroitsk made $3.46 \times 10-4$, which is regarded as the unacceptable carcinogenic risk to population (Table 3).

The assessment of carcinogenic risk in the Ilekskiy district territory showed that the highest individual carcinogenic risk was established for arsenic $\left(2.11 \times 10^{-4}, 35.4 \%\right)$, benz (a) pyrene $\left(1.74 \times 10^{-4}, 29.2 \%\right)$; chromium $\left(1.58 \times 10^{-4}, 26.5 \%\right)$. The total carcinogenic risk makes $5.95 \times 10^{-4}$ (Table 4 ).
In the analysis of carcinogenic risk in Oktyabrskiy district, the highest individual carcinogenic risk was found in arsenic $\left(8.16 \times 10^{-}\right.$ $5,36.6 \%)$, benz (a) pyrene $\left(4.92 \times 10^{-5}, 22.1 \%\right)$ and chromium $\left(4.8 \times 10^{-5}, 21.5 \%\right)$. The total carcinogenic risk equals to $2.23 \times 10^{-4}$ (see Table 4).

In Tyul'gansky district, the highest individual risk was established for arsenic $(1.34 \mathrm{x}$ $\left.10^{-4}, 72.0 \%\right)$ and chromium (1.91 $\times 10^{-5}$, $10.3 \%)$. The total carcinogenic risk makes $1.86 \times 10^{-4}$ (see Table 4).

In the analysis of the population risk, the highest population carcinogenic risk from exposure to air pollutants and drinking water was detected in Novotroitsk. The lowest population 
risk from carcinogens in atmospheric air was typical for Tyul'ganskiy district; from pollutants in drinking water - for Oktyabrskiy district (Table 5).

Table 5

Population carcinogenic risk

\begin{tabular}{|c|c|c|c|c|c|}
\hline $\begin{array}{r}\mathrm{Pa} \\
\text { rameter }\end{array}$ & $\begin{array}{r}\text { Ty } \\
\text { ul' gansk } \\
\text { y district }\end{array}$ & $\begin{array}{l}\text { Ile } \\
\text { kskiy } \\
\text { district }\end{array}$ & $\begin{array}{l}\text { Ok- } \\
\text { tyabrskiy } \\
\text { district }\end{array}$ & $\begin{array}{c}\mathrm{M} \\
\text { ed- } \\
\text { nogorsk } \\
\text { city }\end{array}$ & $\begin{array}{r}\text { No } \\
\text { voroitsk } \\
\text { city }\end{array}$ \\
\hline $\mathrm{Ai}$ & $7^{31,}$ &,$^{121}$ & ${ }_{1}^{36,}$ & $6^{98,}$ & $\begin{array}{r}46 \\
9,4\end{array}$ \\
\hline ater $\mathrm{W}$ & $0^{14,}$ & 5,3 & 4,2 & $2^{19,}$ & $9^{34,}$ \\
\hline
\end{tabular}

The basic origin for uncertainties is related to incomplete information about all the polluting chemical carcinogens. When assessing the exposure, uncertainty is associated with the specifics of environmental monitoring, since such control takes place only over the priority pollutants identified for the entire territory of Orenburg region.

In determining carcinogenic risk of atmospheric air, the uncertainty is due to the fact that to assess risks we use concentrations obtained from the values of the maximum onetime concentrations, which is especially typical for sampling route sites. This affects overestimation of the total risk value.

It should be noted that when detecting arsenic in drinking water, sensitivity of the applied technique is higher than the reference level, which can lead to reassessment of individual risk, nevertheless, in the comparative analysis of territories under study, using the results is allowable.

Uncertainty in the present work is also related to conventionality of the selected exposure scenario, which does not fully take into account the specific aspects in daily activity of the popula- tion belonging to different age and sex groups, in particular, the time that the potentially exposed population stays in the territory under study.

Therefore, the obtained values of risk parameters in this paper can be considered as relative. The most accurate results in assessing the effect of environmental hazards to health can be really established only in the properly scheduled and targeted epidemiological studies, reducing the uncertainty levels (if possible) by using analytical and laboratory data, and developing scenarios that are closest to real situations.

Conclusions. Thus, as a result of risk assessment in monocities and rural settlements, it was found that the total carcinogenic risk from exposure to chemicals in the air is considered as unacceptable. Such risk requires urgent curative measures.

Carcinogenic risk of chemicals contained in drinking water, both in monocities, and rural settlements, is considered as acceptable, but for monocities it is 1.5-2.0 times higher.

Chromium took the leading role among carcinogens in the atmospheric air of monocities, for rural settlements these were arsenic and benzene.

Among carcinogens contained in drinking water, for rural settlements, chrome and benz (a) pyrene took the leading place, for monocities - arsenic.

The present research is practically important for optimizing and improving the SHM (sanitary and hygienic monitoring) system at the regional level in order to improve data collection system. It is necessary to work out regional programs and activities in assessment of economic damage to public health due to environment pollution.

\section{References}

1. Byctpykh V.V. Gigienicheskaya otsenka vliyaniya pit'evoi vody na zdorov'e [Hygienic assessment of influence exerted on health by drinking water]. Gigiena $i$ sanitariya, 1998, no. 6, pp. 20-22 (in Russian).

2. Bystrykh V.V., Tin'kov A.N.. Makshantsev S.S., Salikhova L.R. Voprosy otsenki ekologicheskogo riska dlya naseleniya [Issues of assessing ecological risk for population]. Zashchitaokruzhayushcheisredy v neftegazovomkomplekse, 2004, no. 8, pp. 67 (in Russian).

3. Zaitseva N.V., May I.V. Regional'nyi opyt ucheta pokazatelei riska dlya zdorov'ya naseleniya v zadachakh prostranstvennogo planirovaniya [Regional experience in accounting parameters of population health risk in spatial planning tasks]. Ars Administrandi, 2011, no. 2, pp. 30-39 (in Russian). 
4. Novikov S.M., Fokin M.V., Unguryanu T.N. Aktual'nye voprosy metodologii i razvitiya dokazatel'noi otsenki riska zdorov'yu naseleniya pri vozdeistvii khimicheskikh veshchestv [Actual problem of methodology and development of evidence-based health risk assessment associated with chemical exposure]. Gigiena i sanitariya, 2016, vol. 95, no 8, pp. 711-716 (in Russian).

5. O sostoyanii sanitarno-epidemiologicheskogo blagopoluchiya naseleniya v Orenburgskoi oblasti v 2015 godu: Gosudarstvennyi doklad [On sanitary-epidemiologic well-being of the population in Orenburg region in 2015: State report]. Orenburg, Upravlenie Federal'noi sluzhby po nadzoru v sfere zashchity prav potrebitelei i blagopoluchiya cheloveka po Orenburgskoi oblasti Publ., 2016, 263 p. (in Russian).

6. Obzor sostoyaniya i zagryazneniya okruzhayushchei sredy v Rossiiskoi Federatsii za 2012 god. [Review on the state and contamination of the environment in the Russian Federation over 2012]. Moscow, Federal'naya sluzhba po gidrometeorologii i monitoringu okruzhayushchei sredy Publ., 2013, 178 p. (in Russian).

7. Anan'ev V.Yu., Kaisarova N.A., Kiku P.F., Izmailova O.A., Trunova I.E. Otsenka riska vozdeistviya na naselenie khimicheskikh kontaminantov $\mathrm{v}$ pishchevykh produktakh i pit'evoi vode [Estimation of risk of influence on the population chemical substances in foodstuff and potable water]. Zdorov'e naseleniya i sreda obitaniya, 2011, no. 8, pp. 30-34 (in Russian).

8. Avaliani S.L., Bezpal'ko L.E., Bobkova A.L., Mishina A.L. Perspektivnye napravleniya razvitiya metodologii analiza riska $\mathrm{v}$ Rossii [The perspective directions of development of methodology of the analysis of risk in Russia]. Gigiena i sanitariya, 2013, no. 1, pp. 33-35 (in Russian).

9. Avaliani S.L., Novikov S.M., Shashina T.A., Dodina N.S., Kislitsin V.A., Mishina A.L. Problemy sovershenstvovaniya sistemy upravleniya kachestvom okruzhayushchei sredy na osnove analiza riska zdorov'yu naseleniya [The urgent problems of the improvement of the environment management system based on the analysis of health risk assessment]. Gigiena i sanitariya, 2014, vol. 93, no. 6, pp. 5-8 (in Russian).

10. Rukovodstvo po ocenke riska dlja zdorov'ja naselenija pri vozdejstvii himicheskih veshhestv, zagrjaznjajushhih okruzhajushhuju sredu R 2.1.10.1920-04 [Guide to health risk assessment when exposed to chemicals polluting the environment 2.1.10.1920-04]. Moscow, Federal'nyj centr Gossanjepidnadzora Minzdrava Rossii publ., 2004, 143 p. (in Russian).

11. Setko A.G., Ochneva G.I., Setko I.M. Faktory, formiruyushchie zdorov'e detskogo naseleniya, prozhivayushchego na urbanizirovannykh territoriyakh, i otsenka riska ikh vozdeistviya [Factors which form health of children population living in urbanized territories and assessment of risks caused by their impacts]. Vestnik Orenburgskogo gosudarstvennogo universiteta, 2005, no. S5, pp. 104-106.

12. Surzhikov V.D., Surzhikov D.V. Otsenka i upravlenie riskom dlya zdorov'ya ot mnogokomponentnogo zagryazneniya okruzhayushchei sredy krupnogo tsentra metallurgii [Assessment and management of human risk due multicomponent environmental pollution in a large metallurgy center]. Gigiena $i$ sanitariya, 2006, no. 5, pp. 32-35 (in Russian).

13. Frolova O.A., Karpova M.V. Otsenka riska razvitiya kantserogennykh i nekantserogennykh effektov pri upotreblenii produktov pitaniya [Risk assessment of carcinogenic and non-carcinogenic effects in the use of food]. Gigiena $i$ sanitariya, 2012, no. 5, pp. 107-108 (in Russian).

14. Environment and health in the WHO European Region: progress, challenges and lessons learned: working document: Regional Committee for Europe 65th session. World Health Organization, Vilnius, 2015, $15 \mathrm{p}$.

15. Progress report on the European Environment and Health Process: working document: Regional Committee for Europe 66th session. World Health Organization, Copenhagen, 2016, 16 p.

Boev V.M., Kryazhev D.A., Tulina L.M., Neplokhov A.A. Assessment of carcinogenic health risk for population living in monocities and rural settelements. Health Risk Analysis, 2017, no. 2, pp. 5460. DOI: 10.21668/health.risk/2017.2.06.eng

Received: 14.01.2017

Accepted: 06.03.2017

Published: 30.06 .2017 
UDC 614.76 (77)

DOI: 10.21668/health.risk/2017.2.07.eng

\title{
POPULATION HEALTH RISK RELATED TO INCREASED CONTENT OF BENZPYRENE IN SOIL
}

\author{
V.V. Suchkov ${ }^{1}$, S.A. Khotimchenko ${ }^{2}$, O.V. Sazonova ${ }^{1,3}$, D.O. Gorbachev ${ }^{1}$, \\ T.K. Ryazanova ${ }^{1}$, E.A. Semaeva ${ }^{1}$
}

${ }^{1}$ Samara State Medical University, 89 Chapayevskaya Str., Samara, 443099, Russian Federation

${ }^{2}$ Federal Research Centre of nutrition and biotechnology, 2/14 Ustinskiy Proezd, Moscow, 109240, Russian Federation

${ }^{3}$ Research Institute of Human Hygiene and Ecology at the Samara State Medical University, 87 Chapayevskaya Str., Samara, 443099, Russian Federation

The article deals with the problem of soil contamination with benzpyrene within sanitary-hygienic zone of an oil refinery plant. We proved that benzpyrene penetrated into soils due to oil-containing wastes and sedimentation of polycyclic aromatic hydrocarbons from powder-gas discharges on soil surface. Benzpyrene concentration detection at the boundary of a sanitary-hygienic zone provides guidelines for determining discharges spread into the atmosphere from stationary sources; it also serves as an indirect parameter characterizing soil self-purification intensity. We treated benzpyrene content in soils as an informative indicator showing soil horizon contamination with polycyclic aromatic hydrocarbons and heavy oil fractions. Over 2015-2016 66 soil samples were taken and analyzed. We detected benzpyrene concentration with Agilent Technologies 7820A GC System «Maestro» gas chromatograph with mass-selective detector Agilent Technologies 5975 Series MSD in full conformity with ISO 18287: 2006. We compared actual benzpyrene concentrations with maximum permissible concentration $(M P C=0.02 \mathrm{mg} / \mathrm{kg})$, confirmed by Hygienic Standard 2.1.7.2041-06. The results of analyzing the samples as per benzpyrene content revealed that it was higher than maximum permissible concentration $(M P C)$ in all of them. Share of samples with benzpyrene content higher than 1.5 MPC varied from $54.5 \%$ to $90.9 \%$ in different seasons. Some places within sanitary-hygienic zone had high benzpyrene concentration in soils reaching 9.85 MPC. High benzpyrene content in soils proves there is persistent soil horizon contamination with polycyclic aromatic hydrocarbons and soil self-purification slows down. And this, in its turn, causes carcinogenic health risk occurrence $\left(1.08 \cdot 10^{-3}-6.55 \cdot 10^{-3}\right)$.

Key words: soil contamination, sanitary-hygienic zone, oil refinery plant, benzpyrene, carcinogen, health risk, maximum permissible concentrations.

Disposal of industrial wastes in large quantities into soil, especially harmful chemical impurities of organic origin, result in gradual decrease in the concentration of humic nitrogen, decelerating or completely stopping multiplication of humifying microorganisms

$[8,11,14]$. Oil refineries operation is accompanied by the formation of oil sludge in considerable volumes, and sewage sludge after mechanical and biological treatment, which are subsequently accumulated in oil pits or disposed at special landfills $[2,6]$. The areas of

(C) Suchkov V.V., Khotimchenko S.A., Sazonova O.V., Gorbachev D.O., Ryazanova T.K., Semaeva E.A., 2017

Vyacheslav V. Suchkov - Candidate of Medical Sciences, assistant at Common Hygiene department (email: slav-vok4us@mail.ru; tel.: +7 (846) 337-55-52).

Sergey A. Khotimchenko - Doctor of Medical Sciences, Professor, temporarily acting as the First Deputy Director (e-mail: hotimchenko@ion.ru; tel.: +7 (495) 698-52-35).

Olga V. Sazonova - Doctor of Medical Sciences, Associate professor, Head (e-mail: ov 2004@ mail.ru; tel.: +7 (846) 332-26-53).

Dmitry O. Gorbachev - Candidate of Medical Sciences, Associate professor at Common Hygiene department (e-mail: dmitriy-426@ rambler.ru; tel.: +7 (846) 337-55-52).

Tatyana K. Ryazanova - Candidate of Pharmaceutical Sciences, assistant at Pharmacy management and Economics department (e-mail: ryazantatyana@mail.ru; tel.: +7 (846) 260-38-06).

Evgenia A. Semaeva - a four-year student at medical and prevention faculty. 
sanitary hygienic zones of oil refineries are moderately polluted with oil products: in the surface soil horizon soil nitrification intensity is reduced, the structure and degradation of nitrifiers and denitrifiers are reduced due to the content of heavy oil fractions and polycyclic aromatic hydrocarbons (PAH) in soil [7, 10]. As studies have shown, PAH are practically resistant to microbial decomposition and remain in the initial concentration in oilcontaminated soil for a long time $[1,7,9]$.

The main representative of PAH being detected in soil is benzpyrene, the first hazard category substance of carcinogenic effect. This harmful impurity enters the soil through air discharges from stationary sources, settling gradually on the soil surface layer. Such contamination occurs primarily within the sanitary-hygienic zone, however, depending on meteorological conditions, benzpyrene can deposit at a long distance from the stationary source. Another reason for benzpyrene penetration in soil is industrial wastes.

Benzpyrene content in soil serves as an informative indicator of soil horizon contamination with PAH and heavy oil fractions. Detection of its concentration at the boundary of sanitary-hygienic zone provides guidelines for determining discharges spread into the atmosphere from stationary sources, and also serves as an indirect parameter characterizing soil self-purification intensity. High concentrations of benzpyrene at the boundary of sanitaryhygienic zones make a considerable contribution to multi-environmental health risks level in location area of a residential zone [3]. Expansion of residential area is especially dangerous, as well as active development of the former sanitary-hygienic zone following its reduction.

The purpose of the study is the sanitaryhygienic assessment of benzpyrene content in the soil on the territory of the sanitaryhygienic zone at the oil refinery with health risk identification.

Materials and methods. Soil samples were taken in the territory of the sanitaryhygienic zone at the Novokuybyshevsk Oil Refinery Plant ("NK NPZ") in four directions: northeastern (NE) - at the distances of 600 and
$1000 \mathrm{~m}$ from the checkpoint; eastern (E) - at the distances of 200, 600 and $1000 \mathrm{~m}$ from the checkpoint; southeastern (SE) - at the distances of 600 and $1000 \mathrm{~m}$ from the stationary source of the oil-dissolved gas discharges; southern (S) - at the distances of 200, 400, 600 $\mathrm{m}$ and $1000 \mathrm{~m}$ from the petroleum products catalyst cracker. The choice of soil sampling points was predicated upon the neighboring location of Novokuybyshevsk city and Lypyagi rural settlement. The soil surface layer was selected by the "envelope" method at $20 \mathrm{~cm}$ depth, according to GOST 17.4.4.02-84 [5]. The mass of one sample made $200 \mathrm{~g}$. In total 66 soil samples were taken and analyzed for the period of 2015-2016. Prior to determining benzpyrene concentrations, all soil samples were subject to pretreatment, in particular, drying at a temperature of $18-20^{\circ} \mathrm{C}$ and ambient relative humidity of $40-60 \%$; sifting through a fine-mesh screen with a cell area of $0.5 \mathrm{~mm}^{2}$; filtering the liquid phase with "white tape" filter. Samples were analyzed with Agilent Technologies 7820A GC "Maestro" system gas chromatograph, with mass-selective detector Agilent Technologies 5975 Series MSD in accordance with the international standard ISO 18287: 2006 [6]. The concentration of benzpyrene was calculated by the ratio of the analyzed sample peak heights to the standard PAH samples dissolved in cyclohexane. The average retention time for benzpyrene prior to peak was 35.23 minutes.

Benzpyrene is a first-category hazard chemical belonging to $2 \mathrm{~A}$ group (carcinogenic agents for human with an extremely high evidence degree), classified by the International Agency for Research on Cancer (IARC). Its molar mass is $252.309 \mathrm{~g} / \mathrm{mol}$, molecular weight is 252.3 (Figure 1). Similar masses exist for benzpyrene-like compounds of $\mathrm{PAH}$ : benzo(b)fluoroanthrene and benzo(k)fluoranthene. Therefore, the concentration of benzpyrene was calculated from the slope ratio of calibration function, minus concentrations of the above substances. Configuration of the obtained chromatogram for the soil sample No. 8 is shown in Fig. 2. 
All the results obtained were grouped by distances and directions from the stationary sources of gross discharges to atmospheric air, as well as from the oil pits. We compared actual concentrations of benzpyrene with the maximum permissible ( $\mathrm{MPC}=0.02 \mathrm{mg} / \mathrm{kg}$ ), approved in the GN 2.1.7.2041-06 [4].

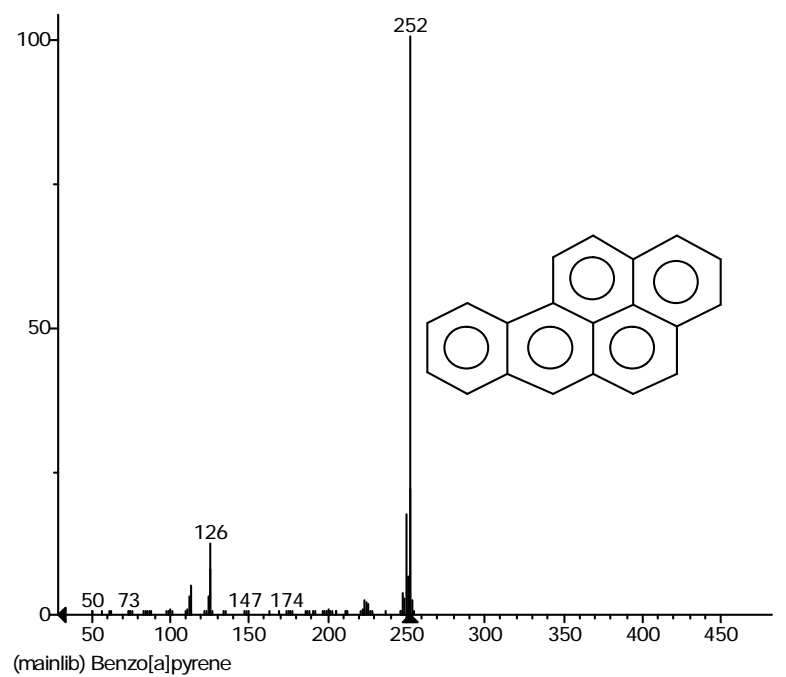

Figure 1. Mass spectrum and structural formula for benzpyrene (NIST 14 mass spectrometry library)

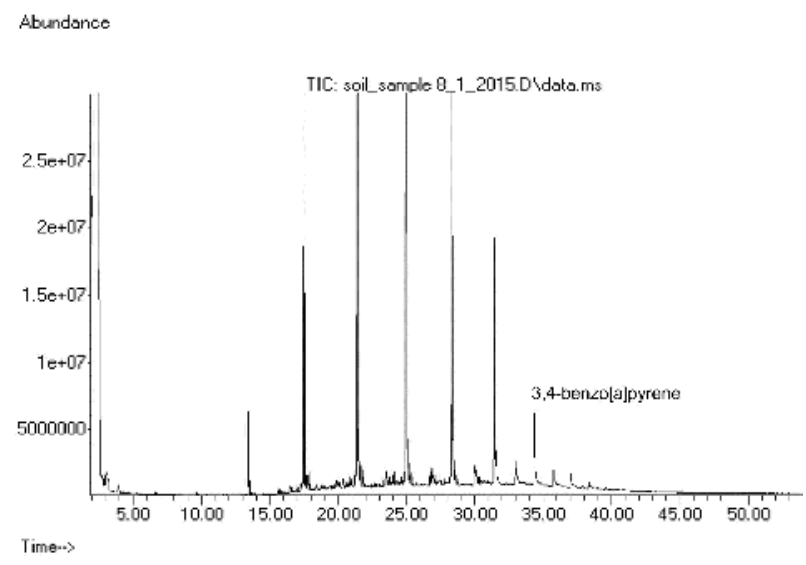

Figure 2. Chromatogram of the soil sample

No. 8 taken in spring 2015.

Analysis of the production and consumption wastes for the oil refinery was carried out according to the annual statistical forms 2-TP (wastes). Health risk was calculated in accordance with the guidelines $\mathrm{P}$ 2.1.10.1920-04 [13]; standard exposure values were used. Statistical data processing was done using $\mathrm{Mi}$ - crosoft Excel 2013 and Statistica 10 Enterprise 10.0.1011.6.

Results and discussion. Novokuibyshevsk Oil Refinery Plant belongs to the first category of hazard, according to SanPiN 2.2.1/2.1.1.1200-03 "Sanitary-hygienic zones and sanitary classification for enterprises, structures and other objects". The basic unit taken for the sanitary-hygienic zone was 1000 $\mathrm{m}$. The consumption and production wastes of the refinery amounted to 28,145 tons for 2014 , and 49,432 tons over 2015. The increase in wastes volumes in 2015 is associated with an increase in oil processing capacity by $56 \%$. Wastes with a high PAH content are formed mainly at washing equipment for storage, processing and transport of oil. It is the sludge after cleaning pipelines and containers (barrels, containers, cisterns and bitumen sprayers) for oil and petroleum products. The big volumes of wastewater, as a result of slurry dilution with industrial water, were exposed to mechanical and bio-treatment. Upon wastewater treatment, sludge settlings containing oil products in the amount of less than $15 \%$ massed 18,470 tons in 2014 , and 40,320 tons in 2015. Sludge settlings in the final stage of disposal are accumulated in oil pits and reservoirs-sedimentation tanks, followed by dumping of oil-containing wastes at landfills, or wastes biodegradation and biotransformation using the components of biostructuring mixture [12].

Oil pits and reservoirs-sedimentation tanks for oil sludge are located in the northwestern part of the oil refinery industrial zone. The minimum distance between the nearest sampling point and the oil pits was $2.4 \mathrm{~km}$. There was no soil sampling done in the northwestern part of the sanitary-hygienic zone, since the nearest residential area 'Mayak' is located at a distance of $6.3 \mathrm{~km}$ from the northwestern border of the oil refinery sanitary-hygienic zone.

When analyzing the laboratory results of the selected samples, it was found that the average concentrations for benzpyrene in soil were higher than MPC: in 2015: $0.0466 \pm$ 
$0.0070 \mathrm{mg} / \mathrm{kg}(2.33 \mathrm{MPC})$, in 2016: $0.0491 \pm$ $0.0068 \mathrm{mg} / \mathrm{kg}$ (2.46 MPC). In all directions from the oil refinery there was a slight increase in benzpyrene concentration (by 0.2-0.5 MPC) in 2016, unlike in 2015. The territory of the eastern part of the sanitary-hygienic zone is more exposed to contamination with PAH: at a distance of $1000 \mathrm{~m}$ from the oil refinery (at the boundary of the sanitary-hygienic zone), we recorded maximum content of benzpyrene: 9.85 MPC. The increasing gradient of benzopyrene content in the eastern direction made 1.8 MPC at increasing the distance from the oil refinery from 200 to $600 \mathrm{~m}$ and $3.5 \mathrm{MPC}$ from 600 to $1000 \mathrm{~m}$.

Table 1

Benzpyrene content $(\mathrm{mg} / \mathrm{kg})$ in the selected samples, depending on the distance to the oil refinery plant

\begin{tabular}{|c|c|c|c|c|c|c|c|}
\hline \multirow{2}{*}{ Sample No. } & \multirow{2}{*}{ Direction and distance to oil refinery } & \multicolumn{3}{|c|}{2015} & \multicolumn{3}{|c|}{2016} \\
\cline { 3 - 8 } & & Spring & Summer & Autumn & Spring & Summer & Autumn \\
\hline 1 & $200 \mathrm{~m}$ to the east & 0,024 & 0,072 & 0,037 & 0,026 & 0,041 & 0,056 \\
\hline 2 & $600 \mathrm{~m}$ to the east & 0,024 & 0,071 & 0,049 & 0,065 & 0,087 & 0,077 \\
\hline 3 & 1000 m to the east & 0,043 & 0,192 & 0,194 & 0,098 & 0,167 & 0,197 \\
\hline 4 & $1000 \mathrm{~m}$ to southeast & 0,024 & 0,051 & 0,055 & 0,059 & 0,043 & 0,053 \\
\hline 5 & $600 \mathrm{~m}$ m to southeast & 0,021 & 0,054 & 0,038 & 0,032 & 0,041 & 0,047 \\
\hline 6 & 200 m to south & 0,021 & 0,045 & 0,042 & 0,036 & 0,037 & 0,041 \\
\hline 7 & 400 m to south & 0,058 & 0,036 & 0,035 & 0,029 & 0,033 & 0,031 \\
\hline 8 & 600 m to south & 0,033 & 0,025 & 0,023 & 0,028 & 0,027 & 0,021 \\
\hline 9 & 1000 m to south & 0,026 & 0,024 & 0,029 & 0,021 & 0,031 & 0,026 \\
\hline 10 & $600 m$ to northeast & 0,061 & 0,024 & 0,026 & 0,025 & 0,034 & 0,027 \\
\hline 11 & 1000 m to northeast & 0,029 & 0,028 & 0,025 & 0,032 & 0,024 & 0,029 \\
\hline
\end{tabular}

In the northeastern part of the sanitaryhygienic zone, the maximum benzpyrene concentrations were recorded in the immediate vicinity of the oil refinery $(600 \mathrm{~m}): 1.85 \mathrm{MPC}$ in 2015 and 1.43 MPC in 2016. In the southern direction from the petroleum products catalyst cracker, benzpyrene level was decreasing by an average gradient of 0.5 MPC with raising the distance from 200 to $600 \mathrm{~m}$. However, at a distance of $1000 \mathrm{~m}$ (at the boundary of the sanitary-hygienic zone), benzpyrene concentration increased slightly to 1.31 MPC. The southeastern direction from the stationary source of the oil-dissolved gas discharges was characterized by the higher content of benzpyrene at increasing the distance from 600 to $1000 \mathrm{~m}$. Data details are presented in Table 1 and Fig. 3.

In 2015 and 2016, the share of samples with the increased MPC level for benzpyrene made $93.55 \%$. In the autumn period, benzpyrene content in 2016 was higher by $9.4 \%$ than in 2015 . In the spring of 2015, the number of samples with benzpyrene level above $1.5 \mathrm{MPC}$ was $54.5 \%$ with an average concentration of 0.042

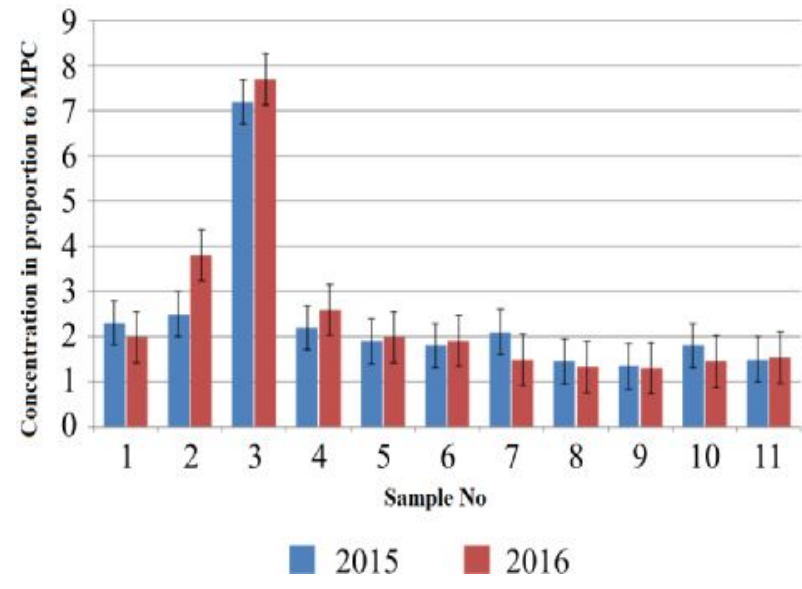

Fig.3. Distribution for benzopyrene concentrations

$\mathrm{mg} / \mathrm{kg}$, in the spring period of 2016: $90.9 \%$ of the average concentration of $0.04 \mathrm{mg} / \mathrm{kg}$. As per benzpyrene content, the soil in the territory of the oil refinery's sanitary-hygienic zone belonged to "hazardous" pollution category, in accordance with SanPiN 2.1.7.1287-03 "Sanitary and epidemiological requirements for soil quality". 
The second way in which benzpyrene enters the soil is PAH discharges settling on the soil surface layer. Depending on meteorological parameters (wind direction and speed, air temperature and humidity), the dispersion range of discharges can both be reduced, limited to the territory of the sanitary-hygienic zone, as well as expanded, including to the settlement and residential areas. During the period of 2015-2016, West wind prevailed in the oil refinery's territory (26\%) with an average speed of $3.4 \mathrm{~m} / \mathrm{s}$. Along with discharges from the stationary sources PAHs enter the atmos- phere with the exhausts of motor vehicles. This may be the reason for an increased content of benzpyrene in the soil at the boundary of the sanitary-hygienic zone in the eastern direction from Oil Refinery Plant, where Novokuibyshevsk is located in the immediate vicinity.

Analyzing and grouping the obtained results per distances from Oil Refinery, we calculated the data for health risk levels (Table 2).

Table 2

Data for carcinogenic and non-carcinogenic health risks, obtained as a result of studying benzpyrene content in soil, depending on the distance to Oil Refinery Plant

\begin{tabular}{|c|c|c|c|c|c|}
\hline \multirow{2}{*}{ Sample No. } & \multirow{2}{*}{$\begin{array}{c}\text { Direction and distance to oil } \\
\text { refinery }\end{array}$} & \multicolumn{2}{|c|}{2015} & \multicolumn{2}{|c|}{2016} \\
\cline { 3 - 5 } & $200 \mathrm{~m}$ to the east & $1,89 \cdot 10^{-3}$ & 7,76 & $1,75 \cdot 10^{-3}$ & 7,18 \\
\hline 1 & $600 \mathrm{~m}$ to the east & $2,04 \cdot 10^{-3}$ & 8,40 & $3,25 \cdot 10^{-3}$ & 13,4 \\
\hline 2 & $1000 \mathrm{~m}$ to the east & $6,08 \cdot 10^{-3}$ & 25,0 & $6,55 \cdot 10^{-3}$ & 27,0 \\
\hline 3 & $1000 \mathrm{~m}$ to southeast & $1,84 \cdot 10^{-3}$ & 7,58 & $2,20 \cdot 10^{-3}$ & 9,04 \\
\hline 4 & $600 \mathrm{~m}$ m to southeast & $1,60 \cdot 10^{-3}$ & 6,59 & $1,70 \cdot 10^{-3}$ & 7,00 \\
\hline 5 & $200 \mathrm{~m}$ to south & $1,53 \cdot 10^{-3}$ & 6,30 & $1,62 \cdot 10^{-3}$ & 6,65 \\
\hline 6 & $400 \mathrm{~m}$ to south & $1,83 \cdot 10^{-3}$ & 7,53 & $1,32 \cdot 10^{-3}$ & 5,43 \\
\hline 7 & $600 \mathrm{~m}$ to south & $1,15 \cdot 10^{-3}$ & 4,73 & $1,08 \cdot 10^{-3}$ & 4,43 \\
\hline 8 & $1000 \mathrm{~m}$ to south & $1,12 \cdot 10^{-3}$ & 4,61 & $1,11 \cdot 10^{-3}$ & 4,55 \\
\hline 9 & $600 \mathrm{~m}$ to northeast & $1,57 \cdot 10^{-3}$ & 6,48 & $1,22 \cdot 10^{-3}$ & 5,02 \\
\hline 10 & $1000 \mathrm{~m}$ to northeast & $1,16 \cdot 10^{-3}$ & 4,78 & $1,21 \cdot 10^{-3}$ & 4,96 \\
\hline 11 & & & & \\
\hline
\end{tabular}

N o t e : *-carcinogenic risk; $* *$ - non-carcinogenic risk.

All levels of health risk belonged to the fourth range of reference limits, and were unacceptable to people health. The maximum value for carcinogenic risk was obtained at the boundary of the sanitary-hygienic zone in the eastern direction from Oil Refinery. Soil was the source of the air-ground interface secondary pollution. According to residential zone scenario, among all the ways for benzpyrene entering a human body, inhalation route prevailed $(99.96 \%)$. The risk factors for development of non-carcinogenic effects were 6-8 times higher than the threshold value; at the boundary of the sanitary-hygienic zone, in the eastern direction to Oil Refinery, the maximum value reached 25 . High levels of health risks indicate an extreme pollution of habitat in the territory of the sanitary-hygienic zone, and the unconditioned disutility for living, in case if former territory of the sanitary-hygienic zone would be developed after reducing its area. Measures to improve environment can help in decreasing PAHs content in soil and, as a result, the health risk level. Complex of measures should include: liquidation of oil pits, processing and recycling of oil sludge, lands rehabilitation and activation of local soil biocenosis by introducing hydrocarbonoxidizing microflora [1].

Conclusions. High concentrations of benzpyrene in soil, exceeding the value of MPC, indicate the persistent contamination of the soil horizon with polycyclic aromatic hydrocarbons and the slow process of soil selfpurification. 
High levels of carcinogenic health risk (1.08 $\mathrm{x} 10^{-3}-6.55 \times 10^{-3}$ ) are due to the high content of benzpyrene in soil, which is absolutely unacceptable for the population health. As the distance from Oil Refinery increases in the eastern and southeastern directions, an increase in the content of benzpyrene in soil is noted, which can negatively affect the health of Novokuibyshevsk' population at eventual reduction of the Oil Refinery' sanitary-hygienic zone.

\section{References}

1. Bioremediacija neftezagrjaznennyh pochv putem stimulirovanija mestnogo pochvennogo mikrobiocenoza: Grantovyj proekt № 97-04-50148 [Bioremediation of contaminated soils by stimulating the local soil microbiocenosis. Grant project Number 97-04-50148]. In: I.G. Kalachkina ed, supported by the Russian Federal Property Fund. Available at: http: //www.rfbr.ru/rffi/ru/project_search/o_151708 (09.09.2016) (in Russian).

2. Galiulin R.V., Galiulina R.A., Bashkin V.N. Ochistka pochvy ot nefti kak sposob zashhity gruntovyh vod ot zagrjaznenija [Cleaning of soil from oil as method of ground waters protection against contamination]. Vodoochistka. Vodopodgotovka. Vodosnabzhenie, 2015, vol. 95, no. 11, pp. 22-25 (in Russian).

3. Kryatov I.A., Tonkopij N.I., Vodjanova M.A., Ushakova O.V., Doner'jan L.G., Evseeva I.S., Matveeva I.S., Ushakov D.I. Garmonizacija gigienicheskih normativov dlja prioritetnyh zagrjaznenij pochvy s mezhdunarodnymi rekomendacijami [Scientific evidence for hygienic standards harmonized with international recommendations for priority polluitions of soils]. Gigiena $i$ sanitarija, 2015, vol. 94, no. 7, pp. 4248 (in Russian).

4. GN 2.1.7.2041-06. Predel'no dopustimye koncentracii (PDK) himicheskih veshhestv v pochve [Hygienic Standard 2.1.7.2041-06. Maximum permissible concentrations (MPC) of chemicals in soils]. Available at: http: //docs.cntd.ru/document/901966754 (09.09.2016) (in Russian).

5. GOST 17.4.4.02-84. Ohrana prirody. Pochvy. Metody otbora i podgotovki prob dlja himicheskogo, bakteriologicheskogo, gel'mintologicheskogo analiza [Nature preservation. Soils. Sampling techniques and samples preparation for chemical, bacteriological, and helminthological analysis: State Standard 17.4.4.02-84]. Moscow, Standartinform publ., 2008, 7 p. (in Russian).

6. D'yachenko V.V., Matasova I.Ju. Zagrjaznenie i dinamika mikrojelementov v pochvah juga Rossii [Pollution with trace elements and their dynamics in soils of southern Russia]. Geojekologija, inzhenernaja geologija, gidrogeologija, geokriologija, 2015, no. 4, pp. 324-332 (in Russian).

7. Kirienko O.A., Imranova E.L. Vlijanie zagrjaznenija pochvy nefteproduktami na sostav mikrobnogo soobshhestva [Effect of soil contamination with oil products on the composition of microbial community]. Vestnik Tihookeanskogo gosudarstvennogo universiteta, 2015, no. 3, pp. 79-86 (in Russian).

8. Kotel'nikova I.M., Sergeeva A.G. Ocenka zagrjaznenija pochv g. Blagoveshhenska policiklicheskimi aromaticheskimi uglevodorodami [Pollution assessment of polycyclic aromatic hydrocarbons in urban soil of Blagoveshchensk] Problemy jekologii Verhnego Priamur'ja, 2013, vol. 15, pp. 8-17 (in Russian).

9. Kuritsyn A.V., Kuritsyna T.V., Kataeva I.V. Bioremediacija neftezagrjaznennyh gruntov na tehnologicheskih ploshhadkah [Bioremediation of petropolluted soils on technological platforms]. Izvestija Samarskogo nauchnogo centra Rossijskoj akademii nauk, 2011, vol. 13, no. 1-5, pp. 1271-1273 (in Russian).

10. Mitrakova N.V., Shestakov I.E. Issledovanie ustojchivosti temno-seryh pochv Permskogo kraja metodom biotestirovanija pri zagrjaznenii pochv tjazhelymi metallami [Research of perm region soils resistance by biotesting methods for heavy metals polluted soils]. Antropogennaja transformacija prirodnoj sredy, 2015, no. 1, pp. 143-147 (in Russian).

11. Dabahov M.V., Dabahova E.V., Titova V.I., Oreshkova N.A. Osobennosti tehnogennoj transformacii pochv Nizhnego Novgoroda [Special features of soil anthropogenic transformation in Nizhniy Novgorod]. Agrohimicheskij vestnik, 2011, no. 2, pp. 21-23 (in Russian). 
12. Chertes K.L., Safonova N.A., Beljakov A.V., Shterenberg A.M. Proekt kompleksa shtabel'nosloevoj biodestrukcii neftesoderzhashhih othodov AO «Novokujbyshevskij NPZ» [Stacked-layered biological destruction of oil-containing wastes: a project by "Novokuybyishevskiy oil-refinery plant JSC"]. Vestnik SGASU. Gradostroitel'stvo i arhitektura, 2016, vol. 22, no. 1, pp. 58-62 (in Russian).

13. Rukovodstvo po ocenke riska dlja zdorov'ja naselenija pri vozdejstvii himicheskih veshhestv, zagrjaznjajushhih okruzhajushhuju sredu R 2.1.10.1920-04 [Guide to health risk assessment when exposed to chemicals polluting the environment 2.1.10.1920-04]. Moscow, Federal'nyj centr Gossanjepidnadzora Minzdrava Rossii publ., 2004, 143 p. (in Russian).

14. Smirnova T.S., Panina Ju.Ju. Monitoring uglevodorodnogo zagrjaznenija pochvy posredstvom analiza ejo fermentativnoj aktivnosti [Monitoring of soil hydrocarbon contamination by analysis of its enzymatic activity]. Zashhita okruzhajushhej sredy v neftegazovom komplekse, 2015, no. 12, pp. 33-38 (in Russian).

Suchkov V.V., Khotimchenko S.A., Sazonova O.V., Gorbachev D.O., Ryazanova T.K., Semaeva E.A. Population health risk related to increased content of benzpyrene in soil. Health Risk Analysis, 2017, no. 2, pp. 61-67. DOI: 10.21668/health.risk/2017.2.07.eng

Received: 02.02.2017

Accepted: 04.05.2017

Published: 30.06 .2017 
UDC $613.1 ; 614.7$

DOI: $10.21668 /$ health.risk/2017.2.08.eng

\title{
TRIAL HYGIENIC ASSESSMENT AND MINIMIZING ENVIRONMENTAL HEALTH RISKS DURING LEADERS COUNCIL MEETING OF SHANGHAI COOPERATION ORGANIZATION COUNTRIES AND MEETING OF LEADERS AND GOVERNMENT HEADS OF BRICS COUNTRIES HELD IN UFA
}

\author{
S.V. Kleyn ${ }^{1,2}$, S.Yu. Balashov ${ }^{1}$, E.G. Stepanov ${ }^{3}$, N.Kh. Davletnurov ${ }^{3}$ \\ ${ }^{1}$ Federal Scientific Center for Medical and Preventive Health Risk Management Technologies, \\ 82 Monastyrskaya Str., Perm, 614045, Russian Federation \\ ${ }^{2}$ Perm State National Research University, 15 Bukireva Str., Perm, 614990, Russian Federation \\ ${ }^{3}$ Federal Service for Surceillance over Consumer Rights protection and Human Well-being, Bashkortostan \\ Republic regional office 58 R. Zorge Str., Ufa, 450054, Russian Federation
}

\begin{abstract}
The article outlines the results and experience obtained in the process of giving scientific grounds for volume and essence of a monitoring program, and detecting territories with health risks for Ufa city population, as well as for participants and visitors during the Summits (SCO member states leaders council and meeting of BRICS leaders and heads of BRICS countries governments). We detected that if unfavorable meteorological conditions occurred (calm or wind weaker than $0.5 \mathrm{~m} / \mathrm{sec}$ ) and if industrial enterprises were working at full capacity together with motorways being under peak loads it could lead to unacceptable health risks in areas where the Summits were organized; such risks for exposed population were related to dangers for respiratory organs ( up to 5.66HI), eyes (up to 3.2HI), and system effects (up to 1.3HI). When we modeled weather conditions which were typical for July risks were assessed as being lower (in relation to respiratory organs up to 2.8HI, eyesight, up to 1.05HI, system effects up to 1.03HI), and an area where such risks could possibly occur was considerably smaller. We didn't detect any unacceptable health risks for participants and visitors of the Summits under exposure to chemical admixtures from drinking water and soil $\left(H I=0.17\right.$ and $H I=3.95 * 10^{-7}$ correspondingly). We suggested optimal programs for monitoring environmental objects aimed at providing maximum control over the situation. We also recommended to perform additional measurements of PM10 and PM2.5 fine-dispersed dust fractions when monitoring air quality. A comprehensive sanitary analysis of drinking water and soil quality control as per standard programs were offered. We created a set of activities which allowed to minimize health risks and to provide safe conditions for the Summits in term of all the examined factors. Implementation of the created monitoring program and recommended sanitary-epidemiologic activities as per data of instrumental air quality examination (more than 40,000 examinations as per 30 admixtures) as well as drinking water and soils during the SCO and BRICS Summits and on the days when the delegations arrived and left allowed to eliminate unacceptable risks for negative impacts on the health of Ufa population, participants, and visitors of the Summits. Participants and visitors of the events didn't suffer from any acute health disorders during this period.

Key words: public and political activities, safety, international legal regulation, environmental factors, population health provision, health risk.
\end{abstract}

Preparing for and holding mass public and political events of an international level in the Russian Federation territory requires signifi- cant efforts. Rospotrebnadzor and other agencies are responsible for ensuring sanitary and epidemiological welfare, and protection from

(C) Kleyn S.V., Balashov S.Yu., Stepanov E.G., Davletnurov N.Kh., 2017

Svetlana V. Kleyn - Candidate of Medical Science, Associate Professor of Human Ecology and Life Safety (e-mail: kleyn@fcrisk.ru; tel.: +7 (342) 237-18-04).

Stanislav Yu. Balashov - head of the complex sanitary-hygienic analysis and examinations techniques laboratory (e-mail: stas@fcrisk.ru; tel.: +7 (342) 237-18-04).

Evgenii G. Stepanov - Candidate of Medical Science, Head (e-mail: Stepanov_EG@02.rospotrebnadzor.ru, tel.: +7 (347) 229-90-99).

Nail Kh. Davletnurov - Head of social-hygienic monitoring department (e-mail: Davletnurov_NKh@02.rospotrebnadzor.ru, tel.: +7 (347) 229-90-50) 
biological and chemical threats, in particular, at planning and scoping areas of preventive focus. According to global and national experience, the scientific grounds and phased strategy for practical implementation of sanitary and epidemiological measures aimed at health security of the population, participants and guests at public and political events are the conditions of priority in ensuring sanitary and epidemiological well-being in a region of events. Security in holding such events at the international level is a kind of an indicator showing the development of a country that holds such events.

According to the WHO Secretariat Report "Global mass gatherings: implication and opportunities for global health security" "... planning and preparedness for mass gatherings includes specific public health measures developed in advance of the event ..." and "... an allhazard approach to public health risks is generally recommended by WHO" [3].

Organizers of major international events, including sports (Olympic Games, Universiades, world championships, etc.), at the preparation stage, are trying to identify and minimize all risks to the health of events participants and guests $[5,9,15,16,18,20]$. At the same time, all risks associated with terrorism and biological threats are under special control at all mass gatherings [1, 3, 13, 14], and are an integral part of the national security system of each state.

At the same time, when organizing social and political events at the international level, it is extremely important to take into account international legal regulation of the right to protect health, freedom and other globally recognized human rights, which imposes the obligation on the state (the host party) to use mechanisms ensuring these rights. In some cases, special general "standards of quality, control and coordination of the participating countries actions" are developed, in other cases the event is organized in accordance with the international medical and sanitary regulations, current legislation of the host state, including the regulatory standards for habitat quality aspects [5].
Reviewing global experience in organizing and holding mass international events showed that in Athens (2004), as for environmental objects, only the quality of drinking water was monitored; in Beijing (2008), in addition to a comprehensive systematic analysis of drinking water, systematic sampling and analysis of atmospheric air samples for sulfur dioxide, fine dust $\left(\mathrm{PM}_{10}\right)$, nitrogen dioxide, carbon monoxide was carried out. In preparation for the XXVII World Summer Universiade in Kazan in 2013, the XXII Winter Olympic Games in Sochi, in 2014, in Russian Federation, as well as within the framework of the present study, preparation for the Council meeting of the States Leaders of Shanghai Cooperation Organization and the meeting of the Heads of BRICS States and Governments in 2015, in Ufa (hereinafter, SCO and BRICS Summits), an attempt was made to assess risks of developing negative responses in relation to health of people, visitors and participants in activities caused by chemicals, with the goal to timely minimize them and arrange an effective control during the period of events $[2,4,6,8$, $10,11,19]$.

Research work on scoping the risk areas for the health of guests and participants in summits, rationale for selection of priority chemical pollutants of habitat, subject to sanitary and epidemiological control in places of public and political events of the international level in Ufa was carried out according to the statement of the Federal Service for Surveillance on Consumers Rights Protection and Human Wellbeing in the Republic of Bashkortostan, No. 02-12-20270, ddt. December 15, 2014.

The purpose of the study was to assess risks for developing negative responses due to the effects of chemicals on the part of the health of population, participants and guests on summits, prioritizing chemical impurities to be systematically monitored in the ambient air, drinking water and soils, and working out measures to minimize health risks to the events participants.

Materials and methods. Ufa city is the administrative center of Bashkortostan Repub- 
lic, an important federal transport hub, large industrial center with a high traffic load. In Ufa, there are 163 large and medium-sized enterprises of various property types, of different economic activities, including enterprises of fuel and energy and machine-building complexes, chemical, timber, woodworking, construction and other industries are concentrated.

According to the study purpose, the objects thereof were: Ufa city territory, the quality of atmospheric air, drinking water and soils, the risks to public health under the influence of chemical factors of environmental pollution during SCO and BRICS Summits.

Based on the regulatory documents in force in Russian Federation that specify environmental factors quality and duration of activities, the priority chemicals were selected according to an assessment of compliance with the hygienic standards for air, drinking water and soil quality, as well as according to the risks assessment of an acute health effects. We considered the criteria and recommendations of the global methodology ("Guidelines for assessing human health risks from environmental hazards") and national harmonized documents.

Within the framework of the present study, the following provisions and assumptions were taken into account for exposure assessment:

- Chemical composition of the atmospheric air (outdoor air) determines chemical composition of the air inside the objects of summits (indoors);

- The Summits duration (3 days) is not critical for the formation of chronic health effects on the events' participants and guests, and determines relevancy of applying criteria for acute harmful effects of chemical nature on humans;

- Unfavorable weather conditions (surface inversion, windless condition, weak dispersion of discharges from enterprises and vehicles) were taken into account in this study;

- During the events (Summits), using water from the centralized drinking water supply system for drinking purposes without additional special devices and cleaning reagents may create extra health risk;

- During Summits, economic entities that provide their operation will function in a regular mode (the study did not take into account any extraordinary and emergency situations).

The assessment of compliance with hygienic standards and risk assessment were carried out in a targeted manner for locations of official events and for the objects of accommodation, catering, medical services for summits' participants and guests at SCO and BRICS Summits (2015) (Figure 1).

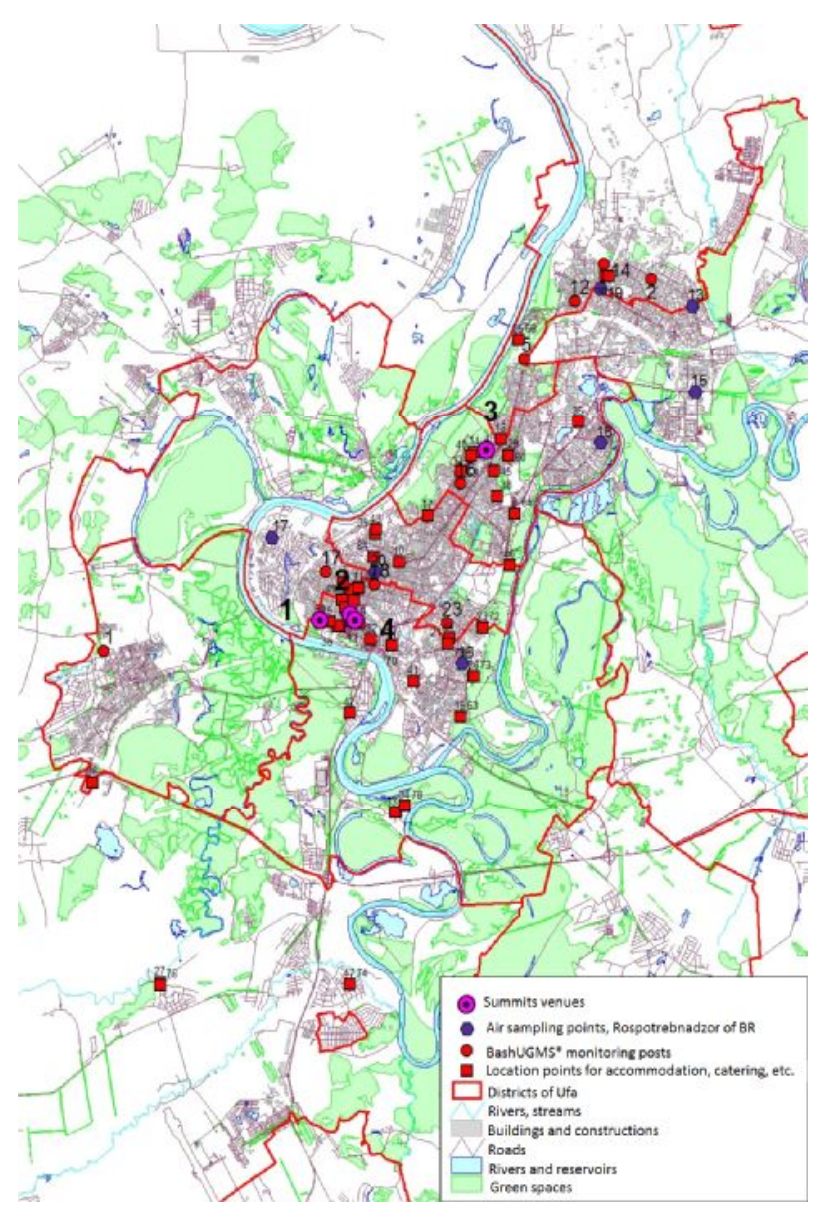

* Bashkir Department for Hydrometeorology and Environmental Monitoring

Fig. 1. Location of facilities for official events, accommodation, catering, medical services for participants and guests on Summits in Ufa, observation posts and air quality monitoring points 
In addressing problems, we used approaches of international methodology and criteria for risk assessment [12, 17], taking into account effects of chemicals contained in the atmospheric air, drinking water and soil.

To identify the priority admixtures, the atmospheric air pollution level was assessed on the basis of instrumental data at 9 monitoring stations of the Bashkir Hydrometeorology and Environmental Monitoring Center, and 8 monitoring points of the Center for Hygiene and Epidemiology in the Republic of Bashkortostan (2009-2014); and the simulation results of impurities dispersion (more than 55 thousand points) were also taken into account.

In view of the dominating long-term annual average wind rose with the prevalence of south-south-west winds and the location of six major industrial enterprises of the city, which account for about $80 \%$ of all discharges from the stationary sources in Ufa city, at a considerable distance to the northeast, we carried out an inventory of the mobile air pollution sources at Ufa' main transport highways. The distance from the Summits venues to the largest industrial enterprises was $8864.7-24539.2$ $\mathrm{km}$.

The forecast estimate was based on the dispersion of impurities in the ambient air following the consolidated available database on the sections of the roads network, which were considered as the sources of emissions from the motor vehicles (238 city main highways sections with a total length of $285,244 \mathrm{~km}$ and an intensity of between 2,000 and 140,000 cars per day). Calculating the dispersion of pollutants allowed for the most accurate assessment for the distribution of air pollution by motor vehicle emissions as the main source of adverse effects on the atmospheric air during summits.

Calculations for dispersion were done using UPAPE (Unified Program of air pollution estimation) "Ecolog-City 3.0" with the construction registration block and the block for calculating the average annual concentrations (Developer - Company Integral, St. Peters- burg) for the worst meteorological conditions (absence of wind, low dispersion of impurities in the atmosphere) in summer time, as well as for meteorological parameters typical for the time of the Summits (July, north-west wind at a speed of $2.7 \mathrm{~m} / \mathrm{s}$ for Ufa). In total, 9 chemical substances were considered for the initial calculations, i.e. the components of urban vehicle emissions.

The concentrations of pollutants were determined at the grid points (more than 55,000 points) of the calculating rectangle, which area covered almost the entire city (calculation site coordinates: $\mathrm{X} 1=-6995.90 ; \mathrm{Y} 1=6093$ 844.63; X2 = 30 804.10; Y2 = 6039 044.63, width $Z=54,800 \mathrm{~m}$, step along $X$ axis $=200 \mathrm{~m}$, $\mathrm{Y}$ axis $=200 \mathrm{~m}$. In addition, calculations were carried out at 81 points, which were the geometric centers for the objects of summits' official events, catering, medical care for summits participants and guests.

The calculations results were verified with the field survey data from the state posts and air quality monitoring points ${ }^{1}$.

The risk assessment of acute inhalation effects was carried out in accordance with the algorithm, criteria and recommendations $P$. 2.1.10.1920-04 "Guidelines for assessment of risk to public health when exposed to chemicals that pollute environment" [12]. The risk at each calculation point was expressed through hazard ratios and indices (HQ and HI, respectively), assuming that coefficients and hazard

indexes values over a unit are the evidence of an increased risk to health of the exposed people.

The contribution of each chemical to the risk of health disorders was determined in the grid points, at the locations of event facilities, accommodation of the Summits' participants and guests.

Assessment of exposure to water factor was carried out according to the data of the Federal Budgetary Healthcare Institution "Center for Hygiene and Epidemiology in the Republic of Bashkortostan" (12 monitoring

\footnotetext{
${ }^{1}$ Territorial zoning method in terms of risk level to the population health under conditions of exposure to chemically hazardous substances: Patent for Invention RUS 2441600 ddt. 31.08.2010/Zaitzeva N.V., May I.V., Klein S.V., Vekovshinina S.A., Balashov S. Yu. - M., 2010.
} 
points) and the Central Chemical and Bacteriological Laboratory of Municipal Unitary Enterprise "Ufavodokanal" (2012-2014). The soil quality assessment was done according to the monitoring data of the Federal Budgetary Healthcare Institution "Center for Hygiene and Epidemiology in the Republic of Bashkortostan" in 8 locations (2013-2014). Assessment of health risks from exposure to chemical factors of drinking water and soil was performed based on the data of the instrumental studies with relevant recording [12].

As the priority admixtures, we identified those impurities for which incompliance with the hygienic standards was forecasted and/ or which most significantly contributed to the formation of acute health risks at the events locations. Using the results obtained, the risk assessments comprised a list of priority chemicals subject to sanitary and epidemiological control, and also formed the proposals for arranging the additional monitoring points and measures to minimize health risks.

Results and discussion. According to the report of the Ministry of Natural Resources, Republic of Bashkortostan, in the recent years, more than 100 kinds of chemical substances with a total mass exceeding 200 thousand tons of pollutants have been emitted into the city's atmospheric air. In 2014, compared to the previous year, insignificant growth of emissions into the air from the stationary sources was registered: by $1.1 \%$ (148.2 thousand tons). The structure of emissions from stationary sources in 2014 was dominated by volatile organic compounds: $59.2 \%$, sulfur dioxide: $16.5 \%$, nitrogen oxides: 9.1\%, carbon monoxide: $5.4 \%$.

The share of industrial emissions in the total pollution, in 2009-2012, made about 35$48 \%$, in $2013-64 \%$. The major contribution to the emissions from the stationary sources in 2013 was made by the enterprises of oil refining industry $(77.2 \%)$ and electric power (4.3\%). The pollutants spectrum entering the air from enterprises is considerable. Among the impurities that deteriorate the air quality in the city, there were substances of the first and second hazard categories (chromium, benzene, phenol, acrolein, formaldehyde) and substances with a low irritant threshold (hydrogen sulphide, etc.). More than $77.2 \%$ of all emissions from the stationary sources were formed by JSC "ANK "Bashneft"", a branch of BashneftUNPZ, JSC "ANK "Bashneft"", a branch of Bashneft-Novoil, and JSC "ANK "Bashneft"", a branch of "Bashneft-Ufaneftekhim", about 2.6\%: OJSC" Ufaorgsintez ", located at a significant distance from the north-east of the city center and from the location of the Summits objects.

According to observations of the air basin status carried out by the Bashkir Hydrometeorology and Environmental Monitoring, in 2013, the air pollution level in Ufa was 9, and was characterized as "high". The averageannual concentrations exceeded the maximum permissible levels: 3.3 times for formaldehyde, 1.5 times for benzenpyrene, and 1.2 times for nitrogen dioxide.

During 2013-2014, in Ufa, there were recorded cases of excess in $\mathrm{MPC}_{\text {single max }}$ for hydrogen sulfide: up to $13.3 \mathrm{MPC}$, for nitrogen dioxide: up to $10.8 \mathrm{MPC}$, ethylbenzene: up to 9.5 MAC, suspended substances: up to 6.2 MPC, hydrogen chloride: up to 5.1 MPC, nitrogen oxide: up to 4.4 MPC, benzpyrene: up to 5.8 MPC, carbon oxide: up to 2.6 MPC, xylenes: up to 4.5 MAC, phenol: up to 3.7 MPC, formaldehyde: up to $2.0 \mathrm{MPC}$.

Specific weight of atmospheric air samples exceeding maximum permissible concentrations, in Ufa, \%

\begin{tabular}{|c|c|c|c|c|c|c|c|c|}
\hline \multirow{2}{*}{ Territory } & \multicolumn{2}{|c|}{$\begin{array}{c}\text { Total } \\
\text { exceeds }\end{array}$} & \multicolumn{4}{|c|}{ Excess coefficient } \\
\cline { 2 - 9 } & 2011 & 2013 & 2011 & 2013 & 2011 & 2013 & 2011 & 2013 \\
\cline { 2 - 10 } & 0,9 & 1,02 & 0,7 & 0,67 & 0,2 & 0,24 & 0,05 & 0,07 \\
\hline Ufa city & &
\end{tabular}


According to the Federal Budgetary Healthcare Institution "Center for Hygiene and Epidemiology in the Republic of Bashkortostan", in 2013-2014, Ufa city monitoring posts recorded the exceedences in hydrochloride (up to $2.0 \mathrm{MPC}_{\text {single max }}$ ), in carbon oxide (up to 2.8 $\mathrm{MPC}_{\text {single max }}$ ), suspended substances (up to 1.6 $\mathrm{MPC}_{\text {single max }}$ ), dimethylbenzene (up to 3.9 $\mathrm{MPC}_{\text {single }}$ max), ethenylbenzene (up to 2 $\mathrm{MPC}_{\text {single max }}$ ), lead (up to $1.3 \mathrm{MPC}_{\text {single max }}$ ), etc.

Generally, in Ufa, in 2013, according to the state report "On the status of sanitary and epidemiological well-being in the Republic of Bashkortostan in 2013", $1.02 \%$ of samples with excess in MPC were recorded (table). At the same time, an exceeding the hygienic standards of up to 2.0 MPC was detected for formaldehyde; up to 5.0 MPC - for ethenylbenzene, hydroxybenzene, carbon oxide; for 6 substances (ethylbenzene, dihydrosulphide, dimethylbenzene, nitrogen oxides, suspended substances, hydrochloride) - over 5 MPC.

In 2014, according to the data of the Federal Budgetary Healthcare Institution "Center for Hygiene and Epidemiology in the Republic of Bashkortostan", at the atmospheric air quality monitoring points in the city of Ufa, the following excesses were registered: for nitrogen dioxide (up to $3.3 \mathrm{MPC}_{\text {single max }}$ ), dihydrosulfide (up to $1.1 \mathrm{MPC}_{\text {single max }}$ ), lead (up to $1.2 \mathrm{MPC}_{\text {single max }}$ ), hydrochloride (up to 1.2 $\mathrm{MPC}_{\text {single max }}$ ), carbon oxide (up to $1.7 \mathrm{MPC}_{\text {sin- }}$ gle $\max$ ), suspended substances (up to 1.2 $\mathrm{MPC}_{\text {single max }}$ ), gasoline oil (up to $1.1 \mathrm{MPC}_{\text {single }}$ $\max$ ), formaldehyde (up to $1.1 \mathrm{MPC}_{\text {single max }}$ ), dimethylbenzenes (up to $1.8 \mathrm{MPC}_{\text {single max }}$ ), ethenylbenzene (up to $2.7 \mathrm{MPC}_{\text {single } \max }$ ), methylbenzene (up to $1.5 \mathrm{MPC}_{\text {single }} \max$ ), ethylbenzene (up to $4.4 \mathrm{MPC}_{\text {single max }}$ ).

As per analysis of the drinking water supply parameters, the main source for the water supply in Ufa is 'Ufa' river (for the Demsk water intake - the river Belaya). The Ufa River serves as a direct source for an open river intake facility (the water treatment facilities of the Northern Water Supply Complex), and by $80 \%$ conditions the quality of the underground infiltration waters intakes (of the Southern city water intake, the $2^{\text {nd }}$ upstream infiltration water intake of the Northern Water Supply Complex, the Shakshinsky Water Pipeline of the Northern Water Supply Complex, Izyaksky water intake, "Cooperativnaya Plyana" water intake).

According to the "State report on the natural resources and the environment of the Republic of Bashkortostan in 2013," the water quality in the river Belaya within Ufa city, the Ufa River (Ufa city) changed by 1 class, having passed from the $4^{\text {th }}$ class of "dirty" category to the $3^{\text {rd }}$ one of "very polluted". Among the significant indicators of water pollution in the Ufa and Belaya rivers near Ufa city are manganese, iron, copper, sulphates, phenol, and oil products.

According to the Central chemical and bacteriological laboratory of the Municipal Unitary Enterprise "Ufavodokanal" in 2013, 159,089 water samples in total were examined $(157,100$ - in $2012 ; 151,518$ - in 2011) for sanitary and chemical parameters; 66 samples $(0.04 \%)$ of them did not meet hygienic standards (in 2012: 25 (0.02\%), in 2011: 75 $(0.04 \%)$ ); and among 17,619 samples (in 2012: 17,063, in 2011: 14,663) tested for microbiological parameters, 50 samples or $0.3 \%$ (in $2012-65$ or $0.4 \%$; in $2011-85$ or $0.5 \%$ ) did not meet hygienic standards. In 2014, the Central chemical and bacteriological laboratory of the Municipal Unitary Enterprise "Ufavodokanal" totaled 151,252 water samples for sanitary and chemical parameters, and 13,216 samples - for microbiological parameters, 7 or $0.05 \%$ of which did not conform to hygienic standards.

The research of the Federal Budgetary Healthcare Institution "Center for Hygiene and Epidemiology in the Republic of Bashkortostan" in 2013 showed that $15.6 \%$ of the samples did not meet hygienic standards as per sanitary and chemical parameters (turbidity, color, and iron content), and $1.7 \%$ - as per microbiological ones.

According to the socio-hygienic monitoring, summarizing 12 monitoring points data for the drinking water samples in the city dis- 
tricts, including the water intakes "Yuzhny", "Cooperativnaya Plyana", "Severniy", "Demskiy", "Izyakskiy", "Shakshinskiy", "Severniy Kovshoviy", and 5 water supply networks, for 2013-2014, the exceedences were registered for iron - up to 1.4 MPC, nitrates - up to 1.2 MPC, manganese - up to 6.6 MPC. As per microbiological parameters, no exceeding in hygienic standards was recorded.

According to the soil data studied for compliance with the requirements of SanPiN 2.1.7.1287-03 "Sanitary and epidemiological requirements for soil quality", in Ufa, in 2013, an exceedance of the hygienic standards for sanitary and chemical indices was detected in 4 samples (zinc, nickel in concentrations of up to $2 \mathrm{MPC}-2$ samples, from 2 to $5 \mathrm{MPC}-2$ samples). In 2014, the exceeded hygienic standards in terms of chemicals content in soil were recorded in the territory of Ufa city for nickel - up to 1.1 MPC, and zinc - up to 2.7 MPC. As for microbiological and parasitological indicators, no exceeded hygienic standards were registered in 2013-2014. The results of soil study in terms of radiological safety did not exceed hygienic standards.

Thus, hygienic assessment of the habitat quality parameters, according to instrumental measurements, showed that a certain danger to the health of participants in summits, guests and residents of the city may be the atmospheric air pollution, and to a lesser extent - the pollution of natural, drinking waters and soils.

Based on the dispersion calculations (for meteorological conditions and meteorological characteristics unfavorable for dispersion, typical for July 2014), specified with the instrumental measurements data, in the places where the official events of SCO and BRICS Summits were held, as well as at the facilities for accommodation, catering, medical services for participants and guests of the summits, there was established:

- of 19 chemical substances discharged in the atmosphere by the stationary and mobile sources in Ufa city, and having an acute noncarcinogenic effects, all 19 substances generate critical concentrations (above 0.001
$\left.\mathrm{MPC}_{\text {single max }}\right)$ in the surface layer of the atmosphere;

- 18 chemicals create the surface concentration of above $0.1 \mathrm{MPC}_{\text {single max; }}$

- the excess of hygienic standards in terms of $\mathrm{MPC}_{\text {single max }}$ is formed in the city area at the analyzed points for such impurities as nitrogen dioxide, nitrogen oxide, carbon (carbon black), carbon oxide, styrene, ethylbenzene, formaldehyde, gasoline (petroleum, low sulfur).

We revealed that out of 81 objects for summits, in the locations of 33 objects, no exceedence in $\mathrm{MPC}_{\text {single max }}$ was forecasted for none of the components, even in the unfavorable meteorological conditions (Dasko-Garden restaurant complex, the RB Ministry of Agriculture Hall of Columns, "White Hall" restaurant, "Parkoviy" hotel complex, Hotel "President Hotel", GC "Azimut Hotel Ufa", etc.).

Part of the summits' objects were located in zones, where $\mathrm{MPC}_{\text {single } \max }$ exceedences were presumable for a number of impurities, in particular, for unfavorable weather conditions, exceedences in carbon (soot) (up to 3.5 $\mathrm{MPC}_{\text {single max }}$ ), formaldehyde (up to 2.7 $\mathrm{MPC}_{\text {single max }}$ ), ethylbenzene (up to $2.4 \mathrm{MPC}_{\text {sin- }}$ gle max), gasoline (petroleum, low-sulfur) (up to 2.1 $\mathrm{MPC}_{\text {single max }}$ ), nitrogen oxide (up to 2.0 $\mathrm{MPC}_{\text {single max }}$ ), carbon oxide (up to $2.0 \mathrm{MPC}_{\text {sin- }}$ gle max), nitrogen dioxide (up to $1.7 \mathrm{MPC}_{\text {single }}$ max), styrene (up to $1.5 \mathrm{MPC}_{\text {single max }}$ ). For meteorological conditions typical for July 2014, the exceedences were forecasted in styrene (up to $1.5 \mathrm{MPC}_{\text {single max }}$ ), carbon (soot) (up to 1.3 $\mathrm{MPC}_{\text {single max }}$ ), nitrogen dioxide (up to 1.2 $\left.\mathrm{MPC}_{\text {single max }}\right)$.

The obtained results of the predictive assessment for the air quality in places, where SCO and BRICS Summits' official events were held, and at the facilities for accommodation, catering, medical services for participants and guests in the summits, showed that the priority pollutants requiring development of measures to reduce emissions and to keep control during the summits in Ufa, in 2015 are: nitrogen dioxide, nitrogen oxide, carbon (carbon black), carbon monoxide, styrene, ethylbenzene, formaldehyde, gasoline. 
Calculations for acute non-carcinogenic risk, expressed by hazard coefficients and indexes, have shown that the city air pollution from the stationary and mobile sources generates unacceptable risks with respect to respiratory and vision organs, and systemic effects both at SCO and BRICS Summits official events locations, as well as at the facilities of accommodation, catering, medical care for participants and guests in the summits. Unacceptable health risks were formed both under the unfavorable meteorological conditions, when dispersal of admixtures in the atmosphere was difficult and under the meteorological conditions typical for July in Ufa (northwest wind at a speed of $2.7 \mathrm{~m} / \mathrm{s}$ ). Fig. 2 shows cartograms reflecting the acute inhalation risk levels' distribution in the territory of Ufa city with respect to respiratory organs under various meteorological conditions.

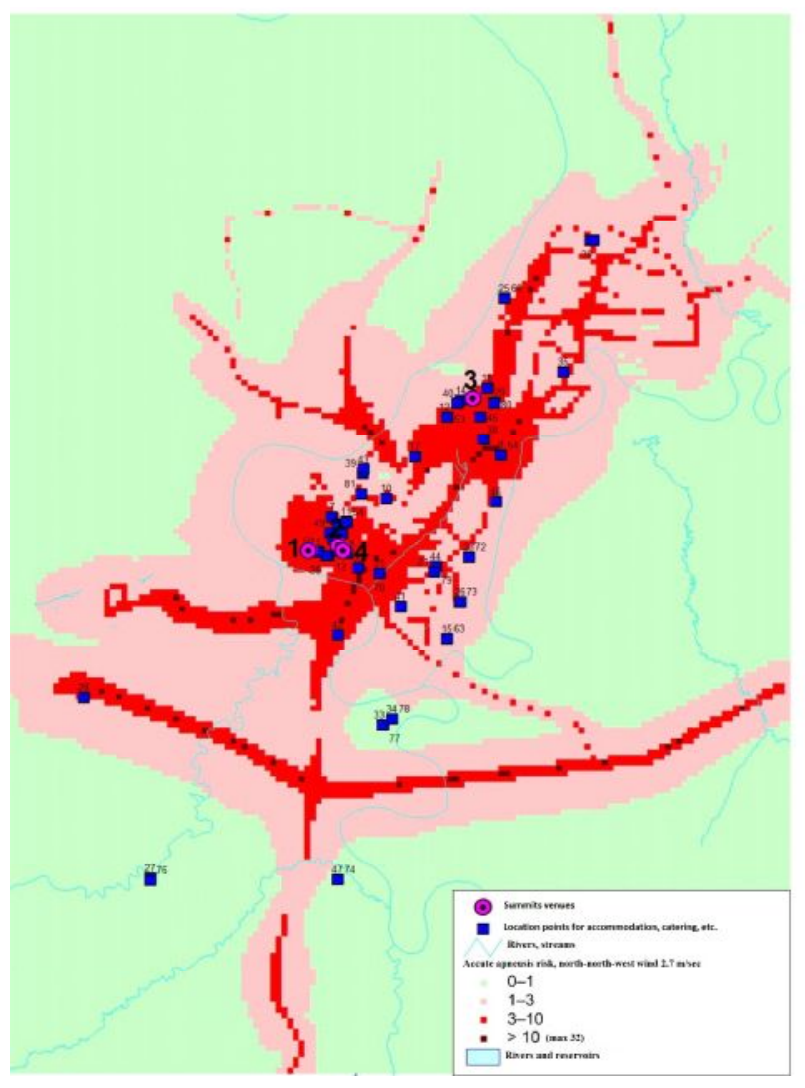

$a$
The highest risk levels (up to $5.7 \mathrm{HI}$, the unfavorable weather conditions in the location of "Agidel" hotel) were forecasted regarding to respiratory organs that is critical, first of all, for the people with allergic diseases, asthma, chronic respiratory disorders. For the organs of vision, under the worst conditions, the unacceptable risk level was generated in 36 points of the Summit facilities' location of up to 3.2 $H I$, including 2 locations of the major events in the summits: the RB State Unitary Enterprise "Congress Hall" (HI 2.3), the state budgetary institution of culture of RB "Bashkir State Theater of Opera and Ballet "(HI 2.1).

An unacceptable risk level of systemic effects was formed at 25 summit objects locations (up to $1.3 \mathrm{HI}$ ) - catering and accommodation facilities for the summits participants and guests.

As for meteorological conditions typical for July 2014, the risk parameters formed had more favorable characteristics.

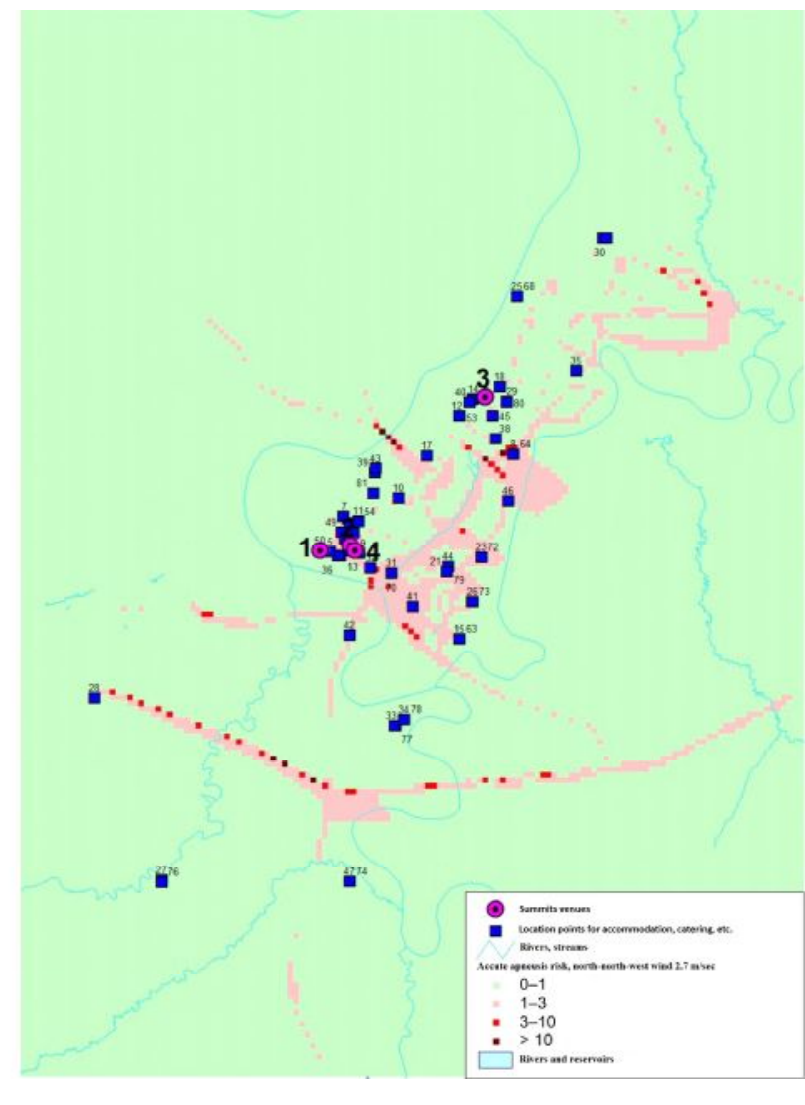

$b$

Fig. 2. Forecasted risk of acute negative effects of atmospheric air pollution on respiratory organs: $a$ - meteorological conditions unfavorable for dispersion; $b$ - typical meteorological characteristics of July 
Nevertheless, an unacceptable risk level for respiratory organs was generated at 57 points of the summit facilities location ( $H I$ up to 2.8), including 2 locations of the Summits major events: SUE RB "Congress Hall" (HI 1.7), the state budgetary institution of culture of RB "Bashkir State Theater of Opera and Ballet" (HI 1.3). The boundary risk level for the visual organs was formed only for the location zone of the "Bashneft" hotel complex (HI 1.05), for systemic effects - for "Panorama" hotel location zone (HI 1.03).

In relation to the rest of the analyzed bodies and target systems, at all location points of the summit facilities, the risk was assessed as acceptable (tolerable).

The identified risks levels of acute inhalation effects were formed by a complex of impurities, but the main contributions were made by no more than 10 priority admixtures out of 16 , considered at the stage of exposure assessment. It was determined that the risk with respect to respiratory organs was formed mainly by: suspended substances, including of finely-dispersed component composition, formaldehyde, nitrogen oxide, nitrogen dioxide, ammonia, hydrogen sulfide, toluene. At the same time, the shares of priority impurities changed depending on the location of the summit facility, but the list of priority pollutants remained unchanged. Thus, the contribution of suspended substances to the hazard index for respiratory organs under unfavorable (worst) weather conditions varied at the different points from 14.9 to $58.7 \%$, of formaldehyde - from 6.8 to $52.7 \%$, nitrogen oxide - from 0.5 to $25.8 \%$, nitrogen dioxide - from 0.96 to $17.0 \%$, ammonia - from 3.0 to $20.7 \%$, toluene - from 0.6 to $11.3 \%$, sulfur dioxide - from 0.2 up to $5.9 \%$, hydrogen sulphide - from 0.43 to $5.6 \%$, hydrochloric acid - from 0.1 to $5.0 \%$, xylene from 0.6 to $2.8 \%$, chloroform - from 0.6 to $2.4 \%$. Other admixtures did not contribute more than $1 \%$.

The contribution of the priority chemical impurities to the formation of hazard index for respiratory organs in weather conditions, typical for July 2014, made for suspended substances: from 26.7 to $79.3 \%$, formaldehyde - from 0.0 to $43.5 \%$, nitrogen oxide - from 0.0 to $23.0 \%$, nitrogen dioxide - from 0.0 to $14.5 \%$, ammonia - from 2.1 to $11.2 \%$, toluene - from 1.1 to $5,2 \%$, sulfur dioxide - from 0.0 to $2.8 \%$, hydrogen sulfide - from 1.3 to $5.4 \%$, hydrochloric acid - from 0.7 to $3.7 \%$, xylene from 0.7 to $4.6 \%$, chloroform - from 0.7 to $4.0 \%$. Other admixtures did not contribute more than $1 \%$.

Thus, the priority chemicals that form acute inhalation risks to the health of the exposed people are the suspended substances (total dusts, including $\mathrm{PM}_{10}, \mathrm{PM}_{2.5}$, formaldehyde, nitrogen oxide, nitrogen dioxide and ammonia. In total, these admixtures in different locations of the summits objects formed from 76 to $94 \%$ of the acute inhalation effects risk for respiratory organs. Irritation of ocular mucosa could be generated under the influence of the higher levels of formaldehyde, ammonia, toluene, xylene, styrene and phenol (the total contribution is $89-99 \%$ of the risk for acute effects on visual organs (ocular mucosa)), i.e. chemical impurities contained in the discharges of a number of the city's industrial enterprises and motor transport emissions.

On the whole, the obtained data made it possible to identify the priority impurities that, contaminating the atmospheric air in Ufa, could be the reason for exceeding the hygienic standards in $\mathrm{MPC}_{\text {single max }}$, and for acute negative effects on the health of the summits participants, guests, and the local population. Nitrogen dioxide, nitrogen oxide, carbon (carbon black), carbon monoxide, styrene, ethylbenzene, formaldehyde, gasoline, suspended matter, ammonia were referred to such impurities.

To set the objectives for risk management, it's been established that the main sources of air pollution due to priority factors in the summits facilities locations are vehicles and small and medium-sized enterprises located in the central part of the city (6 major large industrial enterprises are located in the northeast at a distance of $10-25 \mathrm{~km}$ from the central part of the city, the discharges thereof make about $80 \%$ of all emissions from the stationary sources in Ufa). 


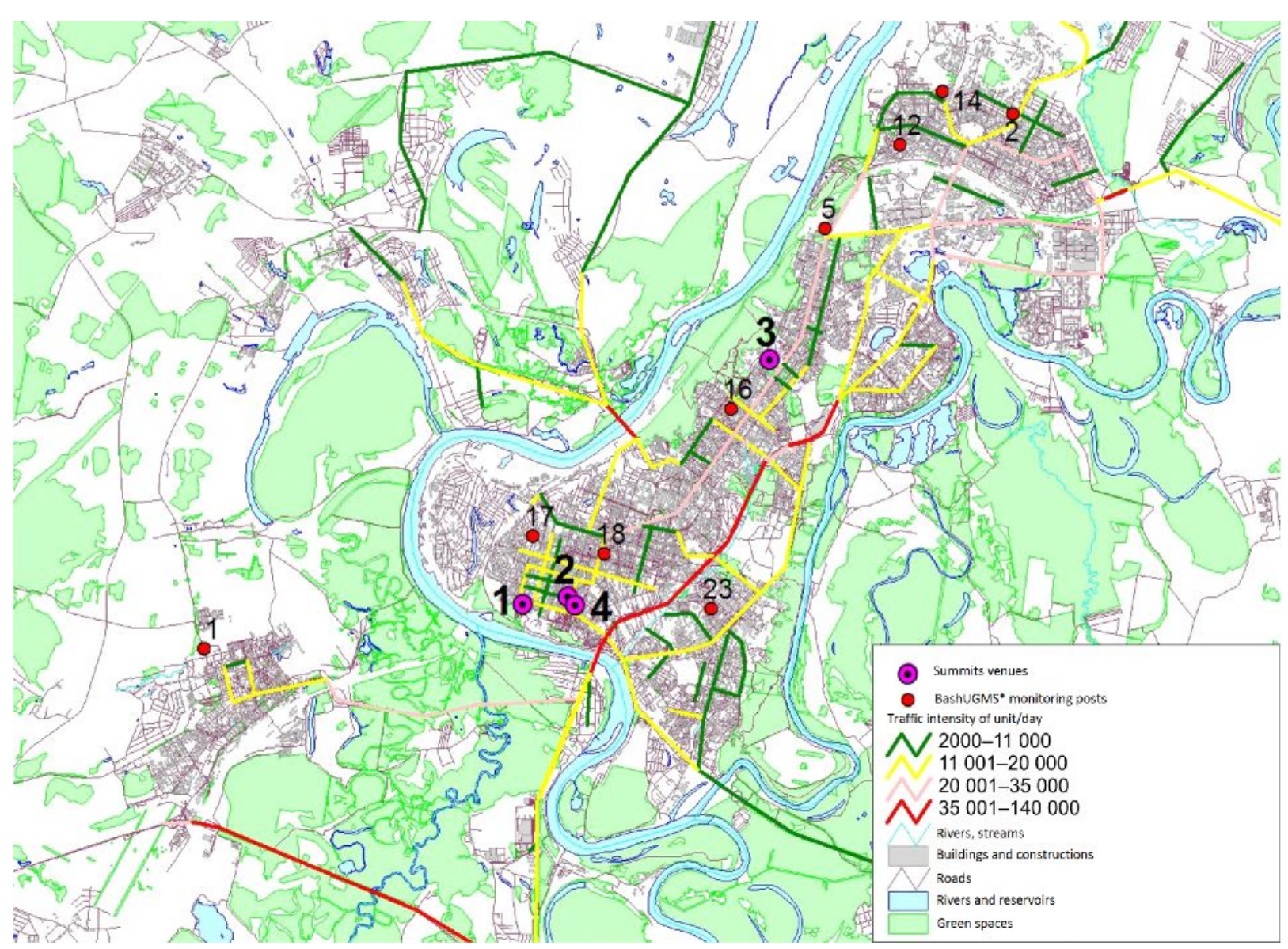

*Bashkir Department for Hydrometeorology and Environmental Monitoring

Fig. 3. Average daily traffic intensity of motor transport in Ufa main highways

Fig. 3 shows the city's main highways with the average daily traffic intensity and their spatial location relative to the main facilities for holding summits in Ufa (2015).

Analyzing water peroral factor at the stage of hazard identification revealed that out of 20 chemical impurities being monitored in the centralized potable water supply system in Ufa, 17 substances have been shown to have the potential to cause adverse effects on human health, including as it relates to gastrointestinal tract, nervous, hematopoietic, reproductive, cardiovascular, immune, endocrine and other body systems.

At the stage of exposure assessment, it's established that the calculated doses for chronic oral intake of the analyzed chemical impurities with drinking water did not exceed the reference levels $(R F D)$ for children and adults at the summits facilities location points. Analysis of the additive unidirectional effect of several drinking water substances on target organs/systems has shown that the chronic impact indexes $\left(\mathrm{THI}_{w o}\right)$ also did not exceed the allowable level for children and adults consuming water in the representativeness zones of monitoring points, and in the summits objects locations (for the latter, $T H I_{w o}$ maximum values were formed for hematopoiesis system at a level of up to $0.17 \mathrm{THI}_{w o}$ ).

Thus, the analysis of health risk for the exposed population, formed by the environmental water peroral factor, showed that chronic non-carcinogenic risk parameters, expressed by hazard coefficients and indexes, did not exceed the permissible level for the adult population for the analysis period. Nitrates, iron, manganese can be referred to as the priority substances (according to the criteria for exceeding hygienic standards); to the relative priorities (substances that form hazard coefficients within the permissible level, but higher 
than other chemical impurities): manganese, benzene, lead, chloroform, mercury.

The soil quality analysis and further expert assessment of the health risk parameters to the population with peroral intake of substances from soil showed that 8 substances out of 9 chemical admixtures monitored in the soils of Ufa city had a proven potential ability to cause adverse non-carcinogenic effects for the health of those exposed, including as it relates to gastrointestinal tract, nervous, hematopoietic, reproductive, immune and other body systems. The calculated coefficients and hazard indexes did not reveal exceedences of the acceptable level for children and adults, both in the representativeness zones of the monitoring points, and at the summits objects location points. At the same time, according to the criteria for maximum permissible concentrations, nickel and zinc should be referred to the priority chemical impurities contained in soils.

In order to minimize risks and prevent health disorders among guests and participants of the summits:

- The priority impurities monitoring programs were developed and further implemented. It is recommended to conduct surveillance studies at the existing observation points of Roshydromet and Rospotrebnadzor for all impurities included in the atmospheric air monitoring programs completing them with instrumental measurements of fine dust fractions $\mathrm{PM}_{10}, \mathrm{PM}_{2.5}$; the drinking water quality control is recommended to be run under a comprehensive sanitary analysis program, the soil - according to the standard programs;

- All sources of potential unacceptable risk were identified, and the enterprises were warned about the need to switch to other operation modes during the periods of unfavorable meteorological conditions. It is recommended to pay special attention to the enterprises located in the central part of the city, and, above all, in close proximity to the places of holding summits, places of catering and accommodation for events guests and participants;
- The necessity to optimize traffic flows for the summits period was proved: redirection of a part of vehicles to other highways; the central part of the city is to be closed for the transit cargo transport; temporary restriction for personal transport to drive on the most stressed sections of the road network for the events duration. There was demonstrated the need to reduce capacity by 4 times of the major, most busy highways: Salavat Yulaev avenue, the bridge across the Belaya River - Gorod Halle, Tsuryupy Street - 50 let Oktayabrya street - Prospect Oktyabrya, Zaki-Validi street - Sochinskaya street;

- The more intensive dust suppression measures are recommended: washing roads using specialized equipment, wetting with watering machines, covering open ground with lawns, etc.

Conclusions. The studies' results showed that in the summits facilities locations, risks of acute negative impacts could be formed under unfavorable weather conditions, which were considerably reduced when the situation was forecasted for the regular July conditions (the month of the events) typical for Ufa. The drinking water and soil in the city did not represent sources of unacceptable health risks. The obtained results allowed for developing a set of activities that ensured minimization of health risks, and safety, from the point of the studied factors in summits holding. The proposed activities can and should be considered not only as a means of achieving a safe living environment for citizens during the period of international events, but also as a means to ensure long-term stable sanitary and epidemiological welfare of Ufa residents.

Implementation of the monitoring program developed, and the proposed sanitary and epidemiological measures, according to the air quality instrumental studies (more than 40 thousand studies for 30 impurities), as well as the drinking water and soils during the SCO and BRICS Summits in Ufa, from 08.07.2015 to 10.07 .2015 , and the arrival and departure days of the summits participants and guests 
allowed for the absence of unacceptable risks of negative effects on the health of Ufa residents, participants and guests of the summits. In that period, there were no cases of acute health problems among the participants and guests of events recorded.

Thus, SCO and BRICS Summits (2015) held demonstrated the effectiveness of meth- odology for assessing non-communicable health risks in preparation and implementation of these activities, including the development and implementation of programs to manage these risks even before the summits' start.

\section{References}

1. Onishchenko G.G., Popova A.Yu., Kuz'kin B.P., [i dr.]. XXII Olimpiiskie zimnie igry i XI Paralimpiiskie zimnie igry 2014 goda v g. Sochi. Obespechenie sanitarno-epidemiologicheskogo blagopoluchiya: monografiya [XXII Winter Olympic Games and XI Paralympic winter games in 2014 in Sochi. Providing sanitary-epidemiologic wellbeing: monograph]. In: G.G. Onishchenko, A. N. Kulichenko eds. Tver, Izdatel'stvo Triada, Publ., 2015, 576 p. (in Russian).

2. Onishchenko G.G., Zaitseva N.V., May I.V. [et al.]. Analiz riska zdorov'yu v strategii gosudarstvennogo sotsial'no-ekonomicheskogo razvitiya: monografiya [Health risk analysis in the strategy of state social and economical development]. In: G.G. Onishchenko, N.V. Zaitseva. Perm, Izd-vo Permskogo natsional'nogo issledovatel'skogo politekhnicheskogo universiteta Publ., 2014, 738 p. (in Russian).

3. Global'nye massovye meropriyatiya: ikh znachenie i vozmozhnosti dlya obespecheniya bezopasnosti zdorov'ya v mire: Doklad Sekretariata [Global mass events: their significance and possibilities to provide health safety in the world: Secretariat Report]. Vsemirnaya organizatsiya zdravookhraneniya, 2011, 8 p. Available at: http: //apps.who.int/iris/bitstream/10665/25910/1/B130_17-ru.pdf (23.03.2016) (in Russian).

4. Zaitseva N.V., May I.V., Kleyn S.V. Optimizatsiya programm nablyudeniya za kachestvom atmosfernogo vozdukha selitebnykh territorii $\mathrm{v}$ sisteme sotsial'no-gigienicheskogo monitoringa na baze prostranstvennogo analiza i otsenki riska dlya zdorov'ya naseleniya [Optimization of programs for monitoring air quality on areas aimed for development in social-hygienic monitoring system on the basis of spatial analysis and population health risk assessment]. Permskii meditsinskii zhurnal, 2010, vol. 27, no. 2, pp. 130-138 (in Russian).

5. Mezhdunarodnye mediko-sanitarnye pravila [International Health Regulations (2005)]. Vsemirnaya organizatsiya zdravookhraneniya, 2008,90 p. Available at: http: //www.who.int/ihr/9789241596664/ru/ (22.02.2017) (in Russian).

6. Imamov A.A., Balabanova L.A., Zamalieva M.A., Radchenko O.R. O planirovanii laboratornykh issledovanii $\mathrm{v}$ tselyakh obespecheniya sanitarno-epidemiologicheskogo blagopoluchiya pri provedenii massovykh meropriyatii [On planning of laboratory researches for ensuring sanitary and epidemiologic wellbeing during carrying out mass actions]. Vestnik Rossiiskoi voenno-meditsinskoi akademii, 2015, vol. 49, no. 1, pp. 185-188 (in Russian).

7. Balakhonov S.V., Chesnokova M.V., Andaev E.I., Kosilko S.A. i dr. Obespechenie sanitarnoepidemiologicheskogo blagopoluchiya $\mathrm{v}$ period podgotovki i provedeniya sammita ATES-2012: monografiya [Providing sanitary-epidemiologic wellbeing during preparation to APEC-2012 Summit and the Summit itself: monograph]. In: G.G. Onishchenko ed. Novosibirsk, Izd-vo Nauka-Tsentr Publ., 2013, 419 p. (in Russian).

8. Vekovshinina S.A., Kleyn S.V., Balashov S.Yu., Nikiforova N.V., Ukhabov V.M. Olimpiada2014 v Sochi: vybor prioritetnykh pokazatelei i razrabotka mer po upravleniyu riskami zdorov'yu ot vozdeistviya khimicheskikh veshchestv [Olympic games 2014 in Sochi: selection of priority indicators and measures of management of health risk caused by chemicals]. Zdorov'e sem'i-21 vek, 2015, no. 3, pp. 9-25 (in Russian). 
9. Olimpiiskaya Khartiya (v deistvii s 9 sentyabrya 2013 g.) [Olympic Charter (came to force on September 9, 2013)]. Mezhdunarodnyi olimpiiskii komitet, 2010. 47 p. Available at: http: //olympic.ru/upload/documents/about-committee/charter/charter_09_09_2013.pdf (23.01.2017) (in Russian).

10. Patyashina M.A., Balabanova L.A. Problemy obespecheniya sanitarno-epidemiologicheskogo blagopoluchiya massovykh meropriyatii $\mathrm{s}$ mezhdunarodnym uchastiem $\mathrm{v}$ sovremennykh usloviyakh [Current problems of surveying sanitary and epidemiological well-being at public events with international participation]. Kazanskii meditsinskii zhurnal, 2015, vol. 96, no. 1, pp. 90-95 (in Russian).

11. Zaitseva N.V., May I.V., Kleyn S.V., Vekovshinina S.A., Balashov S.Yu. Prakticheskii opyt otsenki i upravleniya neinfektsionnymi riskami dlya zdorov'ya pri podgotovke massovykh sportivnykh meropriyatii (na primere Vsemirnoi letnei Universiady - 2013 v Kazani i Olimpiiskikh zimnikh igr $2014 \mathrm{v}$ Sochi) [Practical experience in the assessment and management of non- infectious health risks during the preparation of the mass sports events (using the example of the 2013 summer Universiade in Kazan and the 2014 Winter Olympics in Sochi)]. Zdorov'e naseleniya i sreda obitaniya, 2015, vol. 273, no. 12, pp. 4-7 (in Russian).

12. Rukovodstvo po ocenke riska dlja zdorov'ja naselenija pri vozdejstvii himicheskih veshhestv, zagrjaznjajushhih okruzhajushhuju sredu R 2.1.10.1920-04 [Guide to health risk assessment when exposed to chemicals polluting the environment 2.1.10.1920-04]. Moscow, Federal'nyj centr Gossanjepidnadzora Minzdrava Rossii publ., 2004, 143 p. (in Russian).

13. Onishchenko G.G., Kutyrev V.V., Toporkov V.P., Karnaukhov I.G., Kulichenko A.N., Balakhonov S.V., Toporkov A.V Sovremennye mobil'nye protivoepidemicheskie kompleksy pri preduprezhdenii i operativnom reagirovanii na chrezvychainye situatsii biologicheskogo kharaktera [State-of-the-art mobile anti-epidemic complexes in the prevention of and response to emergency situations of biological character]. Infektsionnye bolezni: novosti, mneniya, obuchenie, 2016, vol. 14, no. 1, pp. 93-101 (in Russian).

14. Udovichenko S.K., Toporkov A.V., Toporkov V.P. Metodologicheskie aspekty otsenki epidemiologicheskikh riskov pri provedenii massovykh meropriyatii s mezhdunarodnym uchastiem [Methodological aspects of epidemiologic risks assessment during mass events with international participation]. Innovatsionnye tekhnologii $v$ protivoepidemicheskoi zashchite naseleniya: Materialy Vserossiiskoi nauchno-prakticheskoi konferentsii, posvyashchennoi 95-letiyu Nizhegorodskii NII epidemiologii $i$ mikrobiologiii im. akademika I.N. Blokhinoi [Innovative technologies in anti-epidemic protection of the population. Materials of the Russian theoretical and practical conference devoted to the 95-the anniversary of I.N. Blokhina's Nizhniy Novgorod Scientific Research Institute for epidemiology and microbiology], 2014, pp. 22-25 (in Russian).

15. Dapeng J., Ljungqvist A., Troedsson H. The health Legacy of the 2008 Beijing Olympic Games. Successes and Recommendations. World Health Organization, 2008, $191 \mathrm{p}$.

16. Enock K. E., Jacobs J. The Olympic and Paralympics Games 2012: literature review of the logistical planning Operational challenges for public health. Public Health, 2008, vol. 122, no. 11, pp. 1229-1238. DOI: 10.1016/j.puhe.2008.04.016.

17. Environmental Health Risk Assessment: Guidelines for assessing human health risks from environmental hazards. Available at: http: //www.eh.org.au/resources/knowledge-centre/enhealth-nationaldocuments (22.07.2016).

18. Shafi S., Booy R., Haworth E. [et al.]. Hajj: health lessonsfor mass gatherings. Public Health, 2008, vol. 1, no. 1, pp. 27-32.

19. London 2012 Olympic and Paralympic Games: Health Protection Agency Testing and Exercising Summary Report, 2013, 7 p. Available at: https: //www.gov.uk/government/uploads/system/uploads/attachment data/ file/398939/1_London_2012_HPA_summary_testing_and_exercising_report.pdf (22.04.2017).

20. Steffen R. Mass gatherings health risks and preventivestrategies. Ther. Vmsch, 2013, vol. 70, no. 6 , pp. 350-352. 
Kleyn S.V., Balashov S.Yu., Stepanov E.G., Davletnurov N.Kh. Trial hygienic assessment and minimizing environmental health risks during leaders council meeting of shanghai cooperation organization countries and meeting of leaders and government heads of BRICS countries held in Ufa. Health Risk Analysis, 2017, no. 2, pp. 68-81. DOI: 10.21668/health.risk/2017.2.08.eng

Received: 25.01.2017

Accepted: 06.03.2017

Published: 30.06 .2017 
UDC 613.888.15: [618.17+616.69] - 057.875

DOI: 10.21668/health.risk/2017.2.09.eng

\section{CONTRACEPTIVE BEHAVIOR AS RISK FACTOR FOR REPRODUCTIVE HEALTH OF JUNIOR STUDENTS ATTENDING A MEDICAL UNIVERSITY}

\section{T.N. Govyazina, Yu.A. Utochkin}

Perm State Medical University named after Academician E.A. Wagner, 26 Petropavlovskaya Str., Perm, 614000, Russian Federation

1-3 year students attending medical and preventive faculty of a medical university were our research object. Our research had many stages, and at the first one our goal was to examine and to assess basic behavioral risks for reproductive health of students attending medical and preventive faculty of a medical university. We conducted a sociological examination via questioning. 428 students were questioned as per materials collecting program which included 74 parameters; they accounted for $91.6 \%$ out of the overall official number of students, $45.0 \%$ male students and $40.0 \%$ female students combined work and studies.

We detected that, as per questioning results, the specific weight of students who took care of their health amounted to $79.2 \%$ boys and $95.2 \%$ girls. However, the students tended to have bad habits, i.e. constant alcohol intake or smoking. And although information on diseases prevention and on how to pursue healthy lifestyle was perfectly available to them, students didn't try to use it and preserve their health. All the respondents said they were against abortion. Girls were likely to adopt a complex approach when choosing a contraceptive, they resorted to hormonal agents, and, with their partners' consent, to condoms. But they often took hormonal agents without any consultations with a gynecologist or an endocrinologist. Contraceptives were rather rarely applied, and students appeared to have no knowledge on risk factors causing reproductive health deterioration. They also tended to be negligent and too self-confident when it came to reproductive health protection. A risk of abortions was very high for girls who didn't use contraceptives, and also all students ran rather high risk of catching sexual diseases.

Sexual education is needed to correct contraceptive behavior; medical workers are a main source of information on reproductive health of young people in 7-10\% cases only. We need to create interactive educational programs on health protection at university level and to involve specialists from health centers and antenatal clinics to participate in them.

Key words: health self-assessment, students, behavioral risk factors, contraceptive behavior, healthy lifestyle, medical activity, organization of specialized medical aid, prevention, reproductive health protection program, management.

There are 5 million students in HEE all over the RF. Without any doubt, students are our country's intellectual potential and it is quite understandable that they are to have strong physical and mental health. We are now conducting pilot medical and social research at the Public Health and Healthcare department; its subject is "Assessment of basic behavioral risks for health of medical university students". The research goal is to study and to assess basic behavioral health risks for students of a medical-prevention faculty; it is also meant to create grounds for working out a program on HEE students' healthy lifestyle.

A part of our research deals with assessing students' reproductive health and contraceptive behavior. Later on we plan to compare the obtained data with the results of medical examinations.

In spite of positive trends which have occurred over the last five years, reproduction of population in the RF, and in Perm region and Perm city as well, is still characterized with high mortality and low birth rate. Reproduc-

(C) Govyazina T.N., Utochkin Yu.A., 2017

Tatyana N. Govyazina - Candidate of Medical Sciences, associate professor at Public Health and Healthcare Department (e-mail: super.oziz@yandex.ru; tel.: +7 (342) 233-23-36).

Yuriy A. Utochkin - Candidate of Medical Sciences, associate professor at Public Health and Healthcare Department (e-mail: super.oziz@ yandex.ru; tel.: +7 (342) 233-23-36). 
tion depends on population health and on the state of their reproductive system.

WHO describes reproductive health as a state of complete physical, mental, and social wealth in all matters concerning reproductive system functioning as well as psychosocial relations at any age [6].

Reproductive health (RH) is a significant part of health as a whole; it takes a leading role in human development and matters a lot for personal and valued aspect of youth lives. Reproductive health is a true reflection of children' and teenagers' health; it stimulates reproduction and it also gives grounds for good health in older age when reproductive years both for a man and a woman are over $[1,5]$.

To achieve simple reproduction of population, it is necessary to have two or three children in each family. Besides, a specific weight of middle-ages and old people is growing every year. Therefore, availability of young qualified specialists reduces and it leads to problems in our economy. One of the tasks which our state considers to be a top priority is to create such social and economic conditions which are truly favorable for giving birth to healthy children, including support provided for a young student family.

Contraception is a tool for preventing an unwanted pregnancy, abortion and its consequences; it also helps to prevent sexual diseases. Contraceptive behavior is a set of behavioral reactions which accompany heterosexual activities and are aimed at protection from an unwanted pregnancy and sexual infections. This behaviors differs greatly from reproductive one as per its functions and properties. Reproductive behavior is a whole system of actions and relations which in the end all lead to a childbirth or to a refusal to have a child, both for a married couple or a single person. Contraceptive culture comprises all sexually mature people. Contraceptive culture matters a lot for students as they study at a HEE at such an age when human sexual activity is at its peak. Reproductive behavior norms in young age are different from those of an older man.
Data and methods. There are totally 3,568 students attending 5 faculties of Vagner's Perm State Medical University.

At the first stage of our work we organized and conducted sociological research via questioning. Data collection program consisted of 74 criteria; we questioned 428 students attending the medical-prevention faculty (out of 467 enlisted in the Dean's Office) or $91.6 \%$ of the total number of students. Respondents as per sex and years were distributed as follows: $84.0 \%$ of the 1st year students; $97.4 \%$ of the 2nd; $95.1 \%$ third-year students; $89.0 \%$, the 4th; $93.3 \%$, the 5th; and $91.6 \%$ the 6 th. Average per cent was 91.6. Questioned students ratio as per sex at the faculty as a whole is $1: 3$. Such gender ratios are also characteristic for I, III and V year students $(1: 2.8 ; 1: 2.9 ; 1: 3.4$ correspondingly). Second-year-students sex ratio is a bit different and is equal to 1:2; IV and VI year students are 1:4. Average sex ratio is 1:3. Consequently, we can consider our sampling to be quite representative, both in qualitative and in quantitative terms.

We chose the medical-prevention faculty as our research ground. A great part of the educational program for these students is dedicated to such matters as healthy lifestyle formation, studying and assessing risk factors which cause various diseases, as well as their prevention. We wanted to find out how students applied their academic knowledge and skills in preserving their own health, including reproductive one.

Results and discussion. Within the framework of our research we analyzed scientific literature on issues of studying reproductive behaviors of students in the RF. Such studies have been conducted in our country since the very beginning of this century.

Reproductive behavior of students in the $\mathrm{RF}$ is formed under influence of the following behavioral risk factors:

- start of sexual relations at a young age;

- a considerable number of students have experienced sexual relations but they don't think such relations imply getting married and childbirth [2]; 
- protection of students' reproduction health during a postponed childbirth period is inefficient [13];

- students tend to be not aware of reproductive behavior as a whole [3];

- high level of sexual diseases is detected: 8.5 cases as per 100 examined. There is strong correlation between sexual diseases and gynecological morbidity among female students. Average annual gynecological morbidity amounted to $19.3 \%$ [17];

- sexual attitudes are rather liberal now and female students tend to often change sexual partners; it leads to growth in gynecological morbidity and later on to problems with childbirth (infertility, miscarriages, giving birth to sick or disabled children) $[14,15]$;

- as per data given in the review by the " RF Statistics" Scientific Research Institute of the Federal State Statistic Service, in 2012 $74.3 \%$ young women had gynecological diseases [12].

Students' reproductive behavior has the following peculiarities:

- number of births per 1000 HEE female students is equal to 3.8 ; number of abortions, 3.4 [17];

- most students use contraceptives and have negative attitude towards abortion;

- they plan to have a family in the future but, as a rule, they think of a family with one or two children; they also think it possible to have children without getting married [15,17];

- smoking, drinking alcohol, taking drugs and steroids, and also a habit to constantly wear skin-tight underwear which a lot of young males have lead to problems in their reproductive system;

- bad habits are more typical among firstyear students even in a higher medical school [8];

- each third young woman in the RF has bad habits and she acquired them during her student years [12];

- lifestyle which students tend to have nowadays doesn't make for health preservation. They value their health but are often neglectful and light-minded in their attitudes towards it. They think that taking care of their health is their parents', doctors', or the state responsibility [7];

- a very important feature which characterizes students' attitude towards their health is occurrence or absence of bad habits. Apart from smoking, alcoholism, drug addictions or toxicomania, here we can mention addiction to coffee, bear, fast food, gaming, computer, extreme leisure, as well as addiction to digital and audiodrugs. They are often used among young people to fight stress $[4,7,11]$;

- students tend to have low sanitary and medical activity. They apply for medical assistance "only in case of necessity" [2, 11];

- there is a problem of unwanted pregnancies and abortions. Students usually have very little knowledge on most efficient contemporary contraception tools [10];

- students most often get information about contraception from their friends and partners, and more rarely from medical workers $(7-10 \%$ cases $)[9,14]$;

- despite female students start their sexual life rather early and usually have several sexual partners, they possess very little knowledge on such matters as protection from unwanted pregnancies, protection from sexual diseases, and protection from cervical carcinoma [11];

- young men's health forms within the time range from a moment when a zygote appears and to a moment when a biological function of reproduction is realized. And it is important to draw their attention to reproduction function during their studies as well as to diseases which can cause its disorders [16];

- stress and over exhaustion, imbalanced nutrition, and poor ecological situation are all risk factors which can cause students' health disorders, including those of their reproductive system;

- creation of predictive program for assessing morbidity risks among socially-adapted young people proved that reproductive performance of a young student family is determined mostly by a health of a female partner [2];

- if we include courses on healthy lifestyle formation and family planning in HEE curricula it will secure better students' aware- 
ness on reproductive health protection $[2,4$, 10, 14];

- creation of interuniversity multi-field outpatient departments and medical education centers will help to increase quality of medical aid rendered to students [2, 13];

- control over quality of medical aid rendered to students in the sphere of reproductive health is not efficient [1].

Analysis of works focused on the results of studying students' reproductive health proves our research is vital.

So, here are the results of the sociological questioning conducted among junior students of the medical-prevention faculty. The total number of students is $252 ; 231$ of them took part in the questioning $(91.7 \%$ of all $1-3$ year students and $53.9 \%$ of all the students enlisted at the faculty). Students during their 1-3- years are officially called junior students. Assistant to Dean responsible for junior years supervises their learning, scientific work and their educational activities.

The respondents ratio as per age was $1: 2,5$. Sampling was considered to be representative as per its main properties. The questioning program contained 74 criteria. There were ten questions on reproductive health protection. We personally distributed, collected, processes and analyzed all the materials.

We studied a very significant parameter of students' health, namely, health selfassessment; we also obtained and assessed a range of behavioral risks influencing its formation. Here are some of our conclusions:

- specific weight of junior students, male and female, who took care of their health amounted to 79.2 and $95.2 \%$ correspondingly;

- 49.2 male students and 46.4 female students assessed their health as "being good";

- there are gender-based discrepancies in assessing one's health as per all sub-groups and all reasons to preserve it.

Having bad habits is the most important feature that characterizes students' attitude towards their health. Health-preserving behavior includes giving up smoking, alcohol, and psychoactive substances. Prevalence of bad habits among students tends to grow steadily. It re- sults in their health deterioration, including reproductive one. Smoking is considered to be a factor which causes immunity disorders both at cellular and humoral levels. And it can lead to inflammatory processes in small pelvis organs, infertility, and ectopic pregnancy.

Our research results revealed that frequency of smoking per 100 males amounted to 28.6 among the 1 st year students; 36.4 , among the 2nd year students; 100.0, among the 3rd years ones; as for females, 13.8 among the 1st year students; 7.5, among the 2nd year students; 15.8, among the 3rd year ones. Prevalence of this bad habit changes depending on an avademic year. We detected statistically authentic discrepancies in prevalence of smoking as per a year among male students: they smoke more often than girls $(t>2)$. Most smoking respondents are heavy smokers as they tend to smoke up to 20 cigarettes a day.

To assess reproductive health we wanted to get better insight into peculiarities of our respondents' contraceptive behavior:

- sexual relations occurrence (in the past and now);

- use of contraceptives (types, consistency);

- reasons why students don't use contraceptives;

- necessity of providing information on contraceptive behavior correction.

Number of 1 st year students who had sexual relations at least once in their life amounted to $80.9 \%$ among males and $43.1 \%$ females; $68.0 \%$ of male 2 nd year students and $63.0 \%$ of female 2 nd year students admitted having them; and among the 3rd year students, $75.0 \%$ and $70.0 \%$, correspondingly. On average the number amounted to $74.6 \%$ males and $58.7 \%$ females. As a rule, they started sexual relations before they entered the university.

At present on average each second male student $(55.0 \%)$ has sexual relations $(55.0 \%$ 1st year students, $54.0 \%$ second year students and $55.0 \%$ third year students). $24.0 \%$ 1st year female students are sexually active; $42 \%$ among the 2nd year ones, and $65.0 \%$, at the 3rd year (44.0\% on average). Our data correlate with the results obtained by T.P. Reznikova (2012) 
When asked if they used contraceptives, 1 st year male students answered "yes' in $18.0 \%$ cases; 2nd year students, in $8.0 \%$, and 3rd year students, in $15.0 \%$. As for females, in 82.3, 28.0 and $42.0 \%$ cases correspondingly. Parameters for males as per all academic years were lower than among females $(t>2)$. It proves that female students are more responsible when it comes to their reproductive health. Only each 10th male student uses condoms as a contraceptive.

Birth rate in the RF amounted to 13.3 per 1,000 people in 2014 and for the first time since 90ties last century it exceeded death rate. Women in the RF actively use contraceptives as a tool to plan childbirth. Hormonal contraception tends to become more widely used in most regions in our country as intrauterine contraceptives are used more rarely. Experts state it happens because living standards become lower and medical assistance gets more expensive. Hormonal contraception level in VolgaVyatskiy region is equal to 6.8 per 100 women; In Zapadno-Sibirskiy, 11.8 [12].

Our questioning revealed that female students constantly took hormonal pills except $1 \mathrm{st}$ year ones; 3 out of 100 among the 2 nd year females, and 21 out of 100, among 3rd year ones.

Frequency of using condoms with a partner's consent amounted to 8.6 out of 100 among the 1st year students; 32 out of 100 , among the 2nd year ones; 36.8 out of 100 , among the 3rd year students. The older the students, the more often girls use condoms. Choice of contraceptives is not made after consulting a gynecologist from an antenatal clinic or a doctor from a polyclinic for students.

As we questioned students who didn't use condoms we detected some reasons for doing that; on average, $73.0 \%$ males and $64.0 \%$ females didn't answer this question; 9.2 and $5.4 \%$ correspondingly told "they were selfconfident"; on average, $4.5 \%$ females "were planning to have children" $(0.0 \%$ among boys); $14.0 \%$ males and $15.5 \%$ females "didn't know why". Even these reasons persuade us that young people really don't give a lot of thought to their reproductive health.
The total number of abortions in the RF amounted to 814,162 in 2014: there was a $7.6 \%$ decrease in comparison with the previous year. This parameter dropped by $6.5 \%$ among women aged 15-49 and it amounted to 22.9 per a 1,000 women; there was a $20.5 \%$ decrease among young females aged 15-17 [12]. Our questioning revealed that students attending our faculty has negative attitude towards abortions.

On average, $13.3 \%$ males and $18.7 \%$ females gave a positive answer to a question "do you need any information on how to improve your sexual health?". Information on such matters is most often discussed with peers; any consultations with medical specialists are sporadic.

Practically all respondents apply for medical aid only in case of emergency. Visits to doctors at a polyclinic for students are not made for prevention reasons. No one knows about medical consultations which are provided by health centers. In students' opinion, paid-for medical aid is not affordable.

Conclusions. As we studied literature on our research theme and conducted our questioning among students attending the medicalprevention faculty, we revealed that:

- students' health, including reproductive one, is a significant parameter of the society intellectual potential;

- specific weight of male and female students who took care of their health amounted to 79.6 and $95.2 \%$ correspondingly;

- number of males and females with health self-assessment as "good" amounts to 49.2 and $46.4 \%$ correspondingly;

- there are gender-based discrepancies in health self-assessment as per all sub-groups and reasons for its preservation;

$-45.0 \%$ males and $40.0 \%$ females with different health self-assessment combined work and studies;

- students tend to have bad habits, including constant alcohol drinking and smoking;

- despite a lot of information on diseases prevention and healthy lifestyle formation is quite available, students don't try to use it and to preserve their health; 
- basic problems of students' lifestyle are irrational nutrition, insufficient physical and medical activity.

Basic peculiarities of contraceptive culture which junior students have are as follows:

- considerable number of them pursue unhealthy lifestyle;

- students prefer condoms among all contraceptives as they are reliable and quite available;

- all respondents reject abortions;

- female students tend to have more complex approach to choice of contraceptives and they use both hormones and condoms;

- girls take hormones without any consultations with gynecologists and endocrinologists. Besides, we don't have such specialists in our students' polyclinic;

- a paid-for consultation in a private polyclinic where students can get highly qualified medical assistance is very expensive;

- most sexually active students don't plan to have children in the nearest future;

- frequency of using contraceptives is rather low;

- students are now aware of risks factors which deteriorate reproductive health;
- students tend to be neglectful and too self-confident when it comes to reproductive health protection;

- girls who don't use contraceptives run very high risks of abortions; all students who don't do it run high risks of sexual diseases;

- junior students need knowledge on sexual education matters to correct their contraceptive behavior;

- gynecology and andrology are included in the senior courses curricula;

- medical workers are the primary source of information on protection of young people's reproductive health only in $7-10 \%$ cases.

Our research results indicate that:

- junior students of the medicalprevention faculty at our university have problems with protection of their reproductive health;

- contraceptive behavior is a health risk factor for medical students;

- it is necessary to create a set of educational programs on students' health protection on the university level with participation of experts from health centers and antenatal clinics.

\section{References}

1. Davidyan O.V., Davidyan K.V. Planirovanie sem'I I okhrana reproduktivnogo zdorov'ya [Planning a family and reproductive health protection]. Molodoi uchenyi, 2011, no. 1, pp. 256-257 (in Russian).

2. Egorova E.I. Puti sovershenstvovaniya okhrany reproduktivnogo zdorov'ya studentov vysshikh uchebnykh zavedenii [Ways of perfection of protection of reproductive health of students of higher educational institutions]. Rossiiskii mediko-biologicheskii vestnik im. akademika I.P. Pavlova, 2010, no. 1, pp. 80-84 (in Russian).

3. Zaitseva M.A., Shamatonova G.L. Reproduktivnoe zdorov'e studencheskoi molodezhi: sostoyanie i problemy [Reproductive health of young students: status and issues]. Formy i metody sotsial'noi raboty $v$ razlichnykh sferakh zhiznedeyatel'nosti: Materialy $V$ mezhdunarodnoi nauchno-prakticheskoi konferentsii, posvyashchennoi 25-letiyu

sotsial'noi raboty $v$ Rossii [Forms and techniques of social work in various fields of activities: Materials of the V international theoretical and practical conference, devoted to 25-th anniversary of social work in Russia]. Ulan-Ude, 2016, pp. 126-127 (in Russian).

4. Kozachuk L.V. Profilaktika narushenii reproduktivnogo zdorov'ya u studentov [Prevention of reproductive health disorders in students]. Nauchnyi al'manakh, 2015, vol. 10, no. 8, pp. 496-498 (in Russian).

5. Opyt razrabotki prognosticheskoi modeli dlya otsenki sostoyaniya reproduktivnogo zdorov'ya sotsial'no-adaptirovannoi molodezhi / T.I. Dolgikh, G.V. Chekmarev, D.A. Serbaev, T.V. Kadtsyna [Creation experience of predictive model to assess the reproductive health status of social-adapted youngs]. Sibirskii meditsinskii zhurnal (Irkutsk), 2013, vol. 123, no. 8, pp. 97-101 (in Russian). 
6. Okhrana zdorov'ya materi i rebenka i planirovanie sem'i: kachestvo pomoshchi: reproduktivnoe zdorov'e: rol' VOZ v global'noi strategii: doklad General'nogo direktora [Protecting a mother and a child's health and planning a family: quality of aid: reproductive health: a role WHO plays in the global strategy: report by Director-General]. Geneva, World Health Organization, 1995, 19 p. (in Russian).

7. Pavlova L.A., Ermolaeva E.V. Zdorov'e i zdorovyi obraz zhizni rossiiskogo studenchestva [Health and healthy lifestyle of Russian students]. Byulleten' meditsinskikh internet-konferentsii, 2016, vol. 6, no. 1, pp. 101-102 (in Russian).

8. Pakhomova Zh.V. Uroven' informirovannosti studentov v voprosakh reproduktivnogo zdorov'ya [Students' awareness on reproductive health issues]. Zhurnal nauchnykh statei Zdorov'e i obrazovanie $v$ XXI veke, 2011, vol. 13, no. 4, pp. 391-392 (in Russian).

9. Pakhomova Zh.V., Pakhomova A.I., Pakhomova N.I. Rasprostranennost' vrednykh privychek sredi studencheskoi molodezhi kak pokazatel' otnosheniya k svoemu zdorov'yu [Bad habits prevalence among young students as a parameter showing attitude towards one's health]. Zhurnal nauchnykh statei Zdorov'e i obrazovanie v XXI veke, 2012, vol. 14, no. 1, pp. 161-162 (in Russian).

10. Petrov Yu.A. Informirovannost' studentov meditsinskikh vuzov v voprosakh kontratseptsii [The features of contraceptive behavior of the medical students]. Mezhdunarodnyi zhurnal prikladnykh $i$ fundamental'nykh issledovanii, 2016, no. 5-5, pp. 751-753 (in Russian).

11. Kutsenko I.P., Kravtsova E.I., Danilova N.R., Khorol'skaya A.E. Razrabotka i vnedrenie informatsionno-obrazovatel'noi programmy po okhrane reproduktivnogo zdorov'ya studentov [Creation and implementation of information and educational program on students' reproductive health protection]. Mezhdunarodnyi zhurnal eksperimental'nogo obrazovaniya, 2012, no. 4-2, pp. 130-133 (in Russian).

12. Reproduktivnoe zdorov'e naseleniya Rossii 2011: Rezyume otcheta [Reproductive health of the Russian Federation population in 2011: Summary of the report]. Moscow, Federal'naya sluzhba gosudarstvennoi statistiki Publ., 2012, 60 p. (in Russian).

13. Sazhina N.S. Okhrana reproduktivnogo zdorov'ya podrostkov kak problema sotsial'noi bezopasnosti v Rossii [Protecting teenagers' reproductive health as a social security issue in Russia]. Sborniki konferentsii NITs Sotsiosfera, 2014, no. 27, pp. 21-23 (in Russian).

14. Stetsenko A.P., Govyazina T.N. Rol' akusherki v sokhranenii reproduktivnogo zdorov'ya zhenshchin [A midwife's role in preserving women's reproductive health]. Innovatsionnye podkhody $v$ reshenii aktual'nykh problem srednego professional'nogo obrazovaniya: sbornik materialov mezhregional'noi pedagogicheskoi nauchno-prakticheskoi konferentsii [Innovative approaches in solving vital tasks of secondary vocational education: collected materials of international pedagogical theoretical and practical conference]. In: L.A. Ponomarevoi ed. Syzran', 2016, pp. 75-78 (in Russian).

15. Stetsenko A.P., Govyazina T.N. Formirovanie reproduktivnogo zdorov'ya i profilaktika bakterial'nogo vaginoza [Reproductive health formation and bacterial vaginosis prevention]. Luchshee iz opyta prepodavaniya: Materialy Vserossiiskoi zaochnoi nauchno-pedagogicheskoi konferentsii [The best teaching experience: Materials of All-Russian correspondence scientific and pedagogical conference]. Saransk, Saranskii meditsinskii kolledzh Publ., 2016, pp. 161-163 (in Russian).

16. Tarusin D.N., Rumyantsev G.A., Gavrilova L.V. Okhrana reproduktivnogo zdorov'ya mal'chikov [Protecting boys' reproductive health]. Praktika pediatra, 2007, no. 5, pp. 12-17.

17. Sharafutdinova L.A., Gurova Z.G. Reproduktivnoe zdorov'e i povedenie studentov, obuchayushchikhsya $\mathrm{v}$ vysshikh uchebnykh zavedeniyakh [Reproductive health and behaviour in students of higher educational institutions]. Meditsinskii vestnik Bashkortostana, 2011, vol. 6, no. 1, pp. 2527.

Govyazina T.N., Utochkin Yu.A. Contraceptive behavior as risk factor for reproductive health of junior students attending a medical university. Health Risk Analysis, 2017, no. 2, pp. 82-88. DOI: 10.21668/health.risk/2017.2.09.eng

Received: 08.04.2017

Accepted: 30.05 .2017

Published: 30.06 .2017 


\title{
ASSESSMENT AND RISK MANAGEMENT HEALTH AND SAFETY IN MEDICAL HEALTH ORGANIZATION
}

UDC 613.6: 62

DOI: $10.21668 /$ health.risk/2017.2.10.eng

\section{HYGIENIC ASSESSMENT OF WORKING CONDITIONS AND OCCUPATIONAL RISK FOR WORKERS HEALTH AT RAILWAY TRANSPORT OBJECTS}

\author{
V.A. Loginova \\ Federal Service for Surveillance over Consumer Rights Protection and Human Wellbeing, Railway transport office, \\ 17 Dubininskaya Str., Moscow, 115054, Russian Federation
}

We performed hygienic assessment of working conditions at railway transport over 2011-2015. We detected a decreasing trend in specific weight of working places where physical factors were higher than hygienic standards and where steam and gases content in working area air was higher than maximum permissible concentrations (MPC). Working conditions of locomotive teams remain most unfavorable as per risk factors. We detected that a priori occupation risk for locomotive teams was characterized with parameters varying from moderate to considerable ones. Occupational noise was determined as a priority risk factor making working conditions category a hazardous one and it corresponded to occupational morbidity structure. We detected that sensorineural hearing loss took a leading place in morbidity both in the branch in general and among locomotive team workers. We also clarified that such workers as engine drivers and their assistants (up to $43 \%$ ) had the greatest specific weight among railway workers with occupational diseases; occupational morbidity among locomotive team workers amounted to 3.0 per 10,000 workers in 2015 while average morbidity among all railway workers amounted to only 1.32 per 10,000 workers. We revealed that occupational diseases were most frequently detected in workers aged 51-60 (51.9\% in 2014) who had worked under hazardous occupational factors influence for longer than 15 years. While there was an overall decreasing trend in occupational morbidity in the branch in 2011-2015 from 1.68 to 1.32 per 10,000 workers, we detected a brunch peculiarity in the risk group, namely, an unsatisfactory trend for growing share of workers with occupational diseases aged 31-40 (from $2.6 \%$ in 2011 to $12 \%$ in 2014) and it requires special attention in terms of risk management.

Key words: working conditions; hazardous occupational factors; occupational diseases; railway transport; occupational noise; occupational risk.

Occupational pathology risks in professional activity are greatly affected by a complex of occupational factors at working place. Studies show that occupational environment factors have an adverse effect on worker's organism, and are the risk factors contributing to diseases development $[7,8,16,17]$.

Assessing the harmful effects on an employee due to certain factors in labor process for the occupational period, and working out mechanisms to manage these factors in order to reduce to acceptable risk levels allows for employees occupational health, and leads to saving labor resources. The specifics and nature of occupational activity at railway transport facilities are such that a considerable number of harmful occupational factors have effect on employees, leading to deterioration in their health and occupational morbidity [3, $6,9,10,15]$.

The research goal was to study dynamics in sanitary and epidemiological situation at railway transport objects with assessment of a priori occupational risk to workers health and

(C) Loginova V.A., 2017

Vera A. Loginova - Deputy head (e-mail: va-loginova@mail.ru; tel. +7 (495) 633-27-19). 
indices of occupational morbidity.

Materials and methods. Based on the data of state statistical reporting of Rospotrebnadzor bodies and institutions for railway transport over 2011-2015, we studied the dynamics in the sanitary-epidemiological situation and occupational morbidity at railway transport facilities. We analyzed occupational environment and labor process factors, carried out general hygienic assessment of the working conditions in accordance with G.2.2.200605 "Guidelines for hygienic assessment of the occupational environment and labor process factors. Criteria for working conditions and their classification" [14]. We made an assessment of a priori occupational risk, according to G.2.2.1766-03 "Guidelines for assessment of occupational health risk for personnel. Organizational and methodological background, principles and criteria for assessment" [13].

Results and discussion. For the period under study, 2011-2015, among the objects related to railway traffic (such as factories, locomotive and wagon repair depots, railway service facilities, communications, power supply), we noted a decrease in the proportion of objects classified to Group III, in terms of sanitary and epidemiological well-being (extremely unsatisfactory): from $23.1 \%$ in 2011 to $19.0 \%$ in 2015 . We detected a decreasing trend in the specific weight of working places that do not meet hygienic standards in terms of noise level: from 28.1 to $22.5 \%$; by the level of vibration: from 24.2 to $12.0 \%$; as per microclimate parameters: from 6.3 to $3.4 \%$; per lighting parameters: from 19.3 to $17.1 \%$ [2].

According to laboratory data for air in the working area, over 2011-2015, there is a tendency to decrease in the specific weight of the steams and gases samples with the exceeded maximum permissible concentrations (MPC), both in general, as well as per substances belonging to the $1^{\text {st }}$ and $2^{\text {nd }}$ hazard category, from 4.6 to $2.9 \%$ and from 4.2 to $2.3 \%$ respectively. At the same time, the specific weight of the working area samples of air with dust and aerosols above the MPC increased from 13.6 to $16.8 \%$, including substances of the $1^{\text {st }}$ and $2^{\text {nd }}$ hazard categories: from 14.2 to $20.9 \%$ [2].
The review of control and surveillance activities showed that the main reasons for unsatisfactory working conditions at production facilities are long operating periods and high deterioration in machine tools and other equipment (metalworking, woodworking, forging machines, etc.); absence or disruption of ventilation at working places, or ventilation inappropriate to production processes (incorrect technical solutions); unbalanced thermal conditions (not enough heaters in the shops, operating air curtains are not interlocked with opening gates); damages to ventilation during gas welding at non-fixed working places, lack of insulation for the most harmful processes.

The most unfavorable working environment is working conditions of locomotive crews: those who work on diesel locomotives, electric locomotives, electric trains and selfpowered railway equipment. Data analysis for 2006-2015 showed the exceedance of hygienic standards in physical factors. At the same time, during the last 5 years (2011-2015) there has been an improvement in the working environment in locomotives: the specific weight of cabins where physical factors do not meet standards decreased from 53 to $26 \%$; according to the noise level non-compliant with hygienic standards, the number of cabins in different years ranged from 20.2 to $45.1 \%$ of the total cabins under survey. It should be noted that the specific weight of cabins with the noise level exceeding the maximum permissible one (MPL) by up to $5 \mathrm{~dB}$ (of those which do not correspond to hygienic noise standards) ranged from 69.0 to $96.4 \%$. The noise level excess by 5-10 dBA was observed in 13.4$3.01 \%$ of the surveyed cabins, by $10-15 \mathrm{dBA}$ in $2.3-11.0 \%$. As per vibration level, the proportion of cabins with MPL excess made 3.9 to $35.6 \%$. The number of cabins (of those that did not meet hygienic requirements in terms of vibration) exceeding the vibration MPL by up to $5 \mathrm{~dB}$ made 67.2 to $90.0 \%$; exceeding the vibration MPL by $5-10 \mathrm{~dB}$ : from 2.7 to $87.5 \%$; by $10-15 \mathrm{~dB}$ : from 5.6 to $30.1 \%$.

According to hygienic criteria [14], the greatest share of working places in locomotive cabins, in terms of noise and vibration levels, 
corresponds to the category of hazardous working conditions of the $1^{\text {st }}$ and $2^{\text {nd }}$ class. Depending thereon, according to G. 2.2.176603 [13], a priori occupational risk for locomotive teams staff is characterized as small (moderate) and medium (considerable), and requires measures to reduce risk [1].

According to risk assessment methodology applied in Rospotrebnadzor bodies and institutions, all occupational factors and health disorders are subject to compulsory recording and assessment, which is used as the basis for "Assessment criteria for occupational risks to the Russian Railways staff, directly involved in trains traffic" [16]. In line with this document, at final assessment, the occupational risk for engine drivers and their assistants is set at a very high level [7].

The occupational morbidity level has a pronounced dynamics to decrease. From 2011 to 2015 , the number of detected occupational diseases decreased from 152 to 104 cases or, in other words, decreased from 1.68 to 1.32 per 10 thousand employees (with the Russian national average of 1.65 per 10 thousand employees in 2015) [10].

For the analyzed period, occupational morbidity structure by nosological forms did not change significantly. The highest specific weight is made up of engine drivers and assistants to engine drivers: $32.9-43.0 \%$, as well as track workers: $19.3-24.3 \%$. Among the diseases, sensorineural hearing loss takes the leading place (up to $73 \%$ ); the second - diseases of dust etiology (up to 13\%); the third is for vibration disease (up to 5\%). Diseases of peripheral nervous system (PNS) and musculoskeletal system rank fourth (up to 9\%).

The occupational morbidity structure for locomotive crews has some specific features, which is determined by the nature of working conditions. Among the diseases, the major share belongs to neurosensory hearing loss $(93.4 \%)$, vibration disease $(9.4 \%)$, peripheral nervous system and musculoskeletal system diseases (1.3\%) [6].

Occupational diseases among all personnel employed at JSC "Russian Railways" are most often registered in the age group of 51-60 with the occupational time-period under influence of hazardous factors for longer than 15 years. In 2011-2015, the proportion of workers in this group ranged from $51.9 \%$ in 2014 to $63.5 \%$ in 2015 . One of the reasons thereto one can consider the workers intention to keep their jobs until retirement, which is explained by the desire to get compensation for work under harmful working conditions. However, there is an unsatisfactory trend to increasing share of workers with occupational diseases in the age group of $31-40$ (in 2011: 2.6\%, in 2014: $12.0 \%$ ). This may indicate a significant impact of harmful occupational factors at a relatively short occupational period under harmful working conditions [2]. A special feature of occupational pathology is the detection of occupational diseases in late, neglected and clinically pronounced stages, which disrupt employee's working ability [13].

The detection of occupational diseases takes place mainly during medical examinations $(81.5-94 \%)$. This suggests that workers do not seek medical help at first manifestations of a disease eventually related to occupation. Workers with a long occupational period under harmful working conditions are subject to indepth medical examination. Such an examination is carried out in specialized medical organizations according to cl. 37, Appendix No.3 to the Order No.302n by the Ministry of Healthcare and Social Development of Russian Federation ddt. 12.04.2011 "On Approving Lists of Harmful and/or Hazardous Occupational Factors and Works in Performance of which the compulsory preliminary and regular medical examinations (medical screenings) are conducted, and the order of mandatory preliminary and regular medical examinations (screenings) for employees involved in heavy works and works under harmful and (or) hazardous working conditions". For 2013-2015, within the railways system, 1,556 workers exposed to harmful occupational factors for more than 5 years were subject to in-depth medical examination, only 57 of them, that made $3.7 \%$, were actually examined.

Conclusions. Despite the fact that railway transport objects (both the facilities related to 
train traffic maintenance, as well as passenger trains cabins (including motor-car) and cargo rolling stock), detect the decreasing trend in the specific weight of the working places where physical factors exceed hygienic standards and MPC levels in terms of steams and gases content in the working area air, as well as such physical factor as occupational environment noise, one can determine the category for working conditions as harmful, and identify the structure of occupational pathology.

The leading place belongs to sensorineural hearing loss - up to $73 \%$, the second place falls to diseases of dust etiology - up to $13 \%$, vibration sickness ranks third - up to $5 \%$, peripheral nervous system (PNS) and musculoskeletal disorders rank fourth - up to $9 \%$.

The occupational morbidity structure for locomotive crews has some peculiarities, which is determined by the nature of working conditions. In the structure of occupational diseases, among workers of locomotive crews, the largest share belongs to neurosensory deafness $-93.4 \%$.

The most unfavorable occupational environment is working conditions of locomotive crews: those who work on diesel locomotives, electric locomotives, electric trains and selfpowered railway equipment. A priori occupational risk here is characterized from moderate to considerable. This determined the greatest specific weight of diseases in locomotive teams in the overall structure of occupational diseases among workers in the railway branch (occupational morbidity index in 2015 made 3.0 per 10 thousand workers at the overall index for the whole railways system of 1.32 per 10,000 workers).

With the general decreasing number of occupational diseases in the railway branch from 2011 to 2015 , from 1.68 to 1.32 per 10 thousand employees, there is a markedly unsatisfactory tendency to increasing share of workers with occupational diseases aged 3140: from $2.6 \%$ (in 2011) to $12.0 \%$ (in 2014). The decrease in the registered occupational pathology under a slight improvement in the occupational environment hygienic conditions speaks for a low quality of regular medical examinations and failure of the preventive focus in occupational medicine.

\section{References}

1. Onishchenko G.G., Zaitseva N.V., May I.V. [et al.]. Analiz riska zdorov'yu v strategii gosudarstvennogo sotsial'no-ekonomicheskogo razvitiya: monografiya [Health risk analysis in state social and economic development strategy: monograph]. In: G.G. Onishchenko, N.V. Zaitseva eds. Moscow, Perm, 2014, 738 p. (in Russian).

2. Analiz sanitarno-gigienicheskogo sostoyaniya ob"ektov gosudarstvennogo sanitarno-epidemiologicheskogo nadzora (po dannym otchetov f.18,28,7) na zheleznodorozhnom transporte za 2009 god: Informatsionnyi byulleten' [Sanitary-hygienic analysis of state sanitary-epidemiologic surveillance objects (as per reports data) at railway transport over 2009: Information bulletin]. Moscow, 2010. Available at: https: //refdb.ru/look/1036869.html (28.08.2016) (in Russian).

3. Borovkova A.M., Kladova T.V., Lazareva Yu.A. Otsenka professional'nogo riska dlya rabotnikov zheleznodorozhnogo transporta [Occupational health risk assessment for rail transport workers]. Sibbezopasnost'-Spassib, 2013, no. 1, pp 26-32 (in Russian).

4. Istoriya stanovleniya i razvitiya mediko-sanitarnoi sluzhby na zheleznodorozhnom transporte Rossii [How medical-sanitary service at Russian railway transport was created and developed]. In: G.G. Onishchenko ed. Moscow, 2016, pp. 118-119 (in Russian).

5. Ishchenko V.I. Uluchshenie uslovii i okhrany truda na zheleznodorozhnom transporte [Improving working conditions and labor protection at railway transport]. Put' $i$ putevoe khozyaistvo, 2005, no. 5, pp. 31-34 (in Russian).

6. Kaptsov V.A., Mezentsev A.P., Pankova V.B. Proizvodstvenno-professional'nyi risk zheleznodorozhnikov [Production-occupational risk for railway workers]. Moscow, 2002, 350 p. (in Russian). 
7. Kas'kov Yu. N. Aktual'nye voprosy obespechenie sanitarno-epidemiologicheskogo blagopoluchiya na zheleznodorozhnom transporte Rossii [Vital issues of providing sanitary-epidemiologic safety at railway transport in Russia]. Sbornik trudov 3-go s"ezda vrachei zheleznodorozhnogo transporta Rossii. Rostov-naDonu, 2013, pp. 364-366 (in Russian).

8. Kas'kov Yu.N., Podkorytov Yu.I. K sovremennomu sostoyaniyu zdorov'ya rabotnikov zheleznodorozhnogo transporta Rossii [Towards the current health status of railway transport workers in Russia]. Byulleten' natsional'nogo nauchno-issledovatel'skogo instituta obshchestvennogo zdorov'ya imeni A.N. Semashko, 2012, no. 4, pp. 61-64 (in Russian).

9. Finochenko T.A., Mamchenko V.A., Kozina L.S., Lysenko A.V. Neblagopriyatnye usloviya truda kak faktor prezhdevremennogo stareniya rabotnikov lokomotivnykh brigad [Unfavorable working conditions as premature aging factors for locomotive teams workers]. Vestnik Rostovskogo gosudarstvennogo universiteta putei soobshcheniya, 2007, vol. 28, no. 4, pp. 104-110.

10. Nikolaevskii E.N., Kazhigalieva G.S. Professional'nye zabolevaniya u mashinistov lokomotivnykh brigad $\mathrm{v}$ sovremennykh usloviyakh [Occupational diseases in engine drivers under contemporary conditions]. Novaya nauka: problemy i perspektivy, 2016, vol. 79, no. 53, pp. 25-27 (in Russian).

11. Ob utverzhdenii pravil «Kriterii otsenki professional'nykh riskov rabotnikov $\mathrm{OAO}$ «RZhD», neposredstvenno svyazannykh s dvizheniem poezdov: Rasporyazhenie OAO «RZhD» ot 21.12.2009 № 2631r [On approving rules «Occupational health risks assessment criteria for workers employed by Russian Railways PLC directly related to train operation: Instruction by Russian Railways PLC dated December 21, 2009 No. 2631p]. Available at: http: //www.businesspravo.ru/Docum/DocumShow DocumID 167300.html (23.09.2016) (in Russian).

12. Pankova V.B. Sovremennye problemy professional'noi patologii na zheleznodorozhnom transporte [Contemporary occupational pathology issues at railway transport]. Collected articles issued by the 90th anniversary of Russian scientific Research Institute of Railway transport (1925-2015.)]. Moscow, 2015, pp. 201-206 (in Russian).

13. R 2.2.1766-03. Rukovodstvo po otsenke professional'nogo riska dlya zdorov'ya rabotnikov. Organizatsionno-metodicheskie osnovy, printsipy i kriterii otsenki: Rukovodstvo [R 2.2.1766-03. Guidelines on assessing occupational health risks for workers. Organizational and methodical grounds, principles and assessment criteria: Guidelines]. Moscow, Federal'nyi tsentr gossanepidnadzora Minzdrava Rossii Publ., 2004, 24 p. (in Russian).

14. R 2.2.2006-05. Gigiena truda. Rukovodstvo po gigienicheskoi otsenke faktorov rabochei sredy i trudovogo protsessa. Kriterii i klassifikatsiya uslovii truda: Rukovodstvo [Labor hygiene. Guidelines on hygienic assessment of working environment and labor process factors. Criteria and working conditions classification: Guidelines]. Available at: http: //docs.cntd.ru/document/1200040973 (06.09.2016) (in Russian).

15. Belyaeva I.V., Dolgusheva O.V., Nifantov V.A., Naumkin A.V. Sostoyanie zdorov'ya rabotnikov zheleznodorozhnogo transporta [Health of railway transport workers]. Sovremennye aspekty promyshlennogo zdravookhraneniya: materialy nauchno-prakticheskoi konferentsii [Contemporary aspects of industrial health care: materials of theoretical and practical conference]. Perm, 2005, pp. 20-23 (in Russian).

16. Eglite M. Darba medicina. Riga, 2000, 704 p.

17. Landon P., Breysse P., Chen Y. Noise exposures of rail workers at a North American chemical facility. Am. J. Ind. Med, 2005, vol. 47, pp. 364-369.

Loginova V.A. Hygienic assessment of working conditions and occupational risk for workers health at railway transport objects. Health Risk Analysis, 2017, no. 2, pp. 89-93. DOI: 10.21668/health.risk/2017.2.10.eng

Received: 20.03.2017

Accepted: 30.06 .2017

Published: 30.06 .2017 
UDC 613.6: 616.9-022.39-057 (571.13)

DOI: $10.21668 /$ health.risk/2017.2.11.eng

\title{
BIOLOGICAL, EPIDEMIOLOGICAL, SANITARY-HYGIENIC, MEDICAL AND BEHAVIORAL OCCUPATIONAL HEALTH RISK FACTORS FOR STOCK-BREEDERS, VETERINARIES AND WORKERS EMPLOYED AT MEAT-PROCESSING ENTERPRISES, CONTACTING BRUCELLAR ANIMALS AND INFECTED MEAT
}

\author{
S.I. Ereniev', O.V. Plotnikova', V.G. Demchenko ${ }^{1}$, N.V. Rudakov ${ }^{1,2}$ \\ ${ }^{1}$ Omsk State Medical University, 12 Lenina Str., Omsk, 644099, Russian Federation \\ ${ }^{2}$ Omsk Scientific Research Feral Herd Infections Institute, 7 Mira Str., Omsk, 644080, Russian Federation
}

\begin{abstract}
We have studied sanitary-hygienic characteristics of working conditions, charts with results of sanitaryepidemiologic examination performed in a zoogenous nidus, outpatient clinic cards and questionnaires filled in by 202 patients living in Omsk region and suffering from occupational brucellosis. The disease usually prevails among stock-breeders, veterinaries and workers employed at meat-processing enterprises. Our goal was to detect risks of occupational, production-induced and general pathology evolvement. Working conditions which all the examined people had to work in corresponded to hazardous (3.3) or even dangerous (4) category as per occurrence of contacts with infectious agents and parasites (biological risk). Apart from biological factor, a number of workers were under complex exposure to ammonia concentrations (higher than MPC), noise higher than MPL, vibration, cooling microclimate, uncomfortable lighting environment, labor process hardness and intensity. There were several factors causing epidemiologic risks as well. Disinfectants were absent or their quantity was

not sufficient; industrial and amenity rooms were not well-organized; there was no central hot water supply or shower rooms, separate rooms for meals, specialized implements for removing abortus and stillborn fetuses and afterbirths, correctly organized burial grounds, or first aid kits. Hygienic health risks were caused by insufficient cleaning agents supply, absence of centralized protecting clothing laundering, and insufficient provision with personal protection means. Occupational health risks resulted from absence of preliminary medical examinations in standard recruitment procedures, irregularity and low quality of periodical medical examinations. Our qualitative assessment of behavioral health risks revealed that a lot of workers tended to have irresponsible medical and hygienic behavior, there were disorders in their work and rest regime (shift work with shifts rotation), nutrition, sleeping and waking. We also found out that the examined workers didn't pursue self-preserving lifestyle as they drank alcohol, smoked, underestimated the importance of being vaccinated against brucellosis and of having medical examinations, and didn't apply for medical aid in due time. We detected the third type of risk-genous behavior, "high risk-genous level, passive" in $28.22 \%$ of our respondents.

Key words: brucellosis, workers employed in stock-breeding and at meat-processing enterprises, occupational risks, biological risks, epidemiological risks, sanitary-hygienic risksu, medical-preventive risks, behavioral risks.
\end{abstract}

There have been positive changes in oc- recently; they are determined by worldwide cupational hygiene and occupational pathology trend of a worker's health growing importance

(C) Ereniev S.I., Plotnikova O.V., Demchenko V.G., Rudakov N.V., 2017

Stepan I. Ereniev - Doctor of Medical Sciences, Professor at Occupational Hygiene and Occupational Pathology Department (e-mail: stepan_ereniev@ mail.ru; tel.: +7-913-635-13-66).

Olga V. Plotnikova - Candidate of Medical Sciences, Associate Professor, Head of Occupational Hygiene and Occupational Pathology Department (e-mail: olga.plotnikova7@ mail.ru; tel.: +7-913-974-31-36).

Vladimir G. Demchenko - Doctor of Medical Sciences, Professor at Occupational Hygiene and Occupational Pathology Department (e-mail: zefir46@ mail.ru; tel.: +7-906-990-92-29).

Nikolai V. Rudakov - Doctor of Medical Sciences, Professor, Head of Microbiology, Virology and Immunology Department (e-mail: rickettsia@ mail.ru; tel.: +7-903-981-13-58). 
as it underlies his or her labor efficiency and safety. And now we can see a necessity to change a paradigm: from a worker's safety and health to his or her health and safety. Within such an approach a working place is a place of high hygienic quality which is under an employer's constant control and where such working conditions are created that a worker can function decently without any occupational risks for his or her health. Federal state sanitary-epidemiologic surveillance in the sphere of providing biological and chemical safety becomes of great importance here [3,5].

Occupational zooanthroponoses include 23 nosologic groups and forms related to infectious, parasitic and protozoan diseases; brucellosis holds the first place among them [15], as its share among occupational infectious diseases has been equal to about $40 \%$ over the last few years.

The basic reasons causing occupational brucellosis are:

- occupational contact with an infectious factor when veterinary and sanitary rules are not observed;

- working places poorly arranged;

- absence of personal protection means [1].

Social and economic significance of brucellosis is determined by:

- the fact that the main affected group is working population;

-explicit trend of the disease becoming a chronic one (in 40-60\% of cases);

- possible eventual disability of patients (specific weight of disability amounts to one third of all the detected cases);

- necessity to bear substantial economic costs for examining population in order to detect primary contagion, and for treating brucellosis and its consequences;

- occupational nature of brucellosis.

In spite of relatively low level of registered brucellosis morbidity in the RF over the last 1015 years (0.3-0.4, not higher than 0.5 per 100 thousand people), the true parameters are much higher. Only first diagnosed ("fresh") cases are registered while chronic forms are not accounted. Approximately 5\% acute forms and $95 \%$ chronic forms of all the first diagnosed cases of occupational brucellosis are registered in Russia and it proves that the infection is detected too late. So we can state there are no data on true prevalence of brucellosis among the RF population.

Incomplete morbidity data are related not only to lower medical aid appealability among rural population, and decreases in volumes of scheduled prophylactic medical examinations of people employed in stockbreeding (including cattle owners), but also to underdeveloped laboratory diagnostics of brucellosis, especially its chronic forms $[16,17,18]$. But if a diagnosis is put promptly and correctly, and treatment is also prompt and starts in due time it leads to substantial decrease in infectious processes becoming chronic and in patients' disability [20].

More active "adjusting" appeal of people suffering from brucellosis to get a consultation from an occupational pathologist is one of the factors which underlie growth in occupational brucellosis detection; people appeal for medical aid to get confirmation that their disease is associated with their occupation [11].

An issue of brucellosis over the last years has been greatly determined by existing risks of carrying the infection with contaminated cattle coming from adverse territories of the neighboring states (Mongolia, Kazakhstan, Kirgizia and others) with the consequent formation of local infection niduses and possibility of unapparent brucellosis caused by Brucella abortus $[10,13]$.

Population migration which has grown over the last 2 decades and insufficient veterinary and sanitary control over imports of cattle from countries with adverse brucellosis situation, including neighboring CIS countries, can nowadays make poor epizootic and epidemiologic situation as per this infection even worse. Due to uncontrolled imports of cattle from adverse countries there have been cases of the infection carrying into Samara, Vladimir, Chelyabinsk, Sverdlovsk, Omsk, Kaluga, Murmansk, and Altai regions.

Rates of big and small cattle hygienics have decreased substantially over the last 2 decades. Trade in vaccinated animals' meat is 
prohibited in the WTO member countries; and in order to join the WTO, Kazakhstan eliminated annual two-time vaccination as vaccination with strain- 82 which had been adopted in the country earlier was considered by the WTO experts to be dangerous and causing the disease. As a result of this decision, mass epidemics among cattle occurred in Kazakhstan, and annually 2,500-3,500 new brucellosis cases are registered among people [4].

$17.1 \%$ of all brucellosis morbidity in the $\mathrm{RF}$ are detected in Siberian Federal District. Infected people are detected practically in all regions there. Adverse situation with small cattle brucellosis in Kazakhstan which borders Omsk region causes a threat of epidemiologic situation becoming worse. 167 brucellosis cases have been detected in Omsk region over the last 5 years; $28(16.77 \%)$ of them were occupational ones. In order to prevent brucellosis occurrence and prevalence on Omsk region territory, local authorities approved on "Complex program for preventing and eliminating animal brucellosis and preventing population brucellosis morbidity in Omsk region in 20132017".

Our research goal was to examine potential occupational, epidemiologic, sanitaryhygienic, medical, and behavioral health risk factors in stock-breeders, veterinaries, and workers employed at meat-processing production who had contacts with brucellosisinfected animals and infected raw materials.

Data and methods. We examined working conditions at 202 working places at stockbreeding complexes which were occupied by workers with occupational chronic $(78.22 \% ; n$ $=158)$ and residual $(21.78 \% ; n=44)$ brucellosis. $26.23 \%(n=53)$ of patients were able to retrospectively detect the acute phase of the disease. $92.08 \%(n=186)$ workers caught brucellosis when they reached age of being able-bodied. Share of people having 3-1 disability group amounted to $91.1 \%(n=184)$. $38.12 \%(n=77)$ people infected with brucellosis were employed, $2.46 \%(n=5)$ of them had been retrained [10].

Working conditions, brucellosis infection probability, regularity and quality of prelimi- nary and periodical medical examination were studied as per data on sanitary-hygienic properties of working conditions (Appendix No. 2 to the Order by the RF Public Health Ministry No. 176 dated May 28, 2001), corresponding to the Guidelines P 2.2.2006-05 [7], outpatient clinic cards (standard form 025/y-04). We also allowed for the data taken from cards of epizootologic-epidemiologic examination of a zoogenous disease nidus (form № 391/y, approved by the Order of the USSR Public Health Ministry No. 789 dated June 11, 1987) and patients' questioning.

Brucellosis was diagnosed by infection diseases doctors and was confirmed by Burnet sample and Wright and Huddleston serological reactions. Correlation between the disease and an occupation was detected as per data from labor records books, records from outpatient clinic cards, sanitary-hygienic properties of working conditions, cards of epizootologic-epidemiologic examination of a zoogenous disease nidus, information from a veterinary service on seropositive cattle occurrence at a working place and absence of seropositive cattle on private farms.

Statistical analysis of the obtained results was performed with the use of Statistika 6.0, standard applied statistical software [8]. As we compared groups we checked statistical hypotheses with parametric Student's $t$ criterion for independent samplings, onefactor dispersion analysis (ANOVA) and $\chi^{2}$ criterion. Impact value parameter $\left(\eta^{2}\right)$ for an impact exerted by a factor feature on the result was estimated by factorial dispersion fracture $\left(D_{\text {fact }}\right)$ in the overall dispersion $\left(D_{\text {o- }}\right.$ verall), $\eta^{2}$ showed which share belonged to impacts exerted by an examined factor among all the other factors. Zero hypothesis was rejected at $p<0.05$.

Results and discussion. All the examined patients had occupational contact with brucellosis infectious agents. All the patients had working conditions which were assessed as hazardous (class 3.3) or even dangerous (class 4) as per biological hazardous substances content in working area air and probability of con- 
tacts with infectious and parasitic diseases agents.

$40.3 \%$ stock-breeders, $16.4 \%$ veterinaries, and $33.9 \%$ workers employed at meatprocessing production had to work in conditions with production microclimate parameters deviating from hygienic standards; their working conditions corresponded to class 3.1.

Temperature in working areas during cold season varied from +10 to $+15^{\circ} \mathrm{C}$ and on average was equal to $+12.0 \pm 1.2{ }^{\circ} \mathrm{C}$ with relative humidity being equal to $82.9 \pm 3.4 \%$, which corresponded to hazard class 3.1 .

Ammonia content in working area air corresponded to hazard class of working conditions (3.1 and 3.2) for all the veterinaries and $26.6 \%$ of stock breeders.

Organic dust concentrations in working area air exceeded MPC for $8.1 \%$ workers employed at meat-processing production (class 3.1).

$66.1 \%$ of workers employed at meatprocessing production had to work under artificial lighting conditions which corresponded to class 3.1.

Labor hardness of stock breeders and veterinaries was determined by the following: working in a standing position; long-term staying in a fixed position; manual handling and lifting cargos; body bendings; as for workers employed at meat production, their difficulties were multiple stereotype movements $(74.7 \%$ stock breeders and $24.7 \%$ veterinaries had working conditions of class $3.2 ; 62.9 \%$ workers employed at meat-processing production, class 3.2-3.3). As per labor intensity, 3.3\% stock breeders had working conditions which could be classified as hazardous, class 3.1; $32.9 \%$ veterinaries and $43.6 \%$ workers employed at meat-processing production, class 3.2 .

$64.3 \%$ stock breeders, $73.9 \%$ veterinaries, and $49.4 \%$ workers employed at meatprocessing production had disorders in work and rest regime (absence of fixed lunch breaks, overtime work, irregular days off and vacations), and shift work with shift rotation [2,
11]. Stock breeders had the longest working hours and working week together with the shortest vacation; veterinaries had the least number of days off. Besides, more than a half of our respondents had insufficient physical activity, they drank alcohol, smoked, ate unhealthy food; a significant number of them suffered from increased blood pressure, excessive body weight and obesity which can also be called self-destructive behavioral and metabolic health risk factors $[14,19]$ as they cause general and occupationally induced diseases.

A fracture of impacts exerted by cooling microclimate on joints functional defects amounted to $78.7 \%$; on vegetative-sensory polyneuropathy syndrome evolvement, $80.9 \%$. A fracture of impacts exerted by occupational stress (labor intensity) on encephalopathy syndrome amounted to $62.1 \%$ (Table 1).

Sanitary-hygienic and medical-preventive support for the examined stock breeders, veterinaries, and workers employed at meatprocessing production suffering from occupational brucellosis in Omsk region is given in the Table 2.

Allowing for the most mentioned parameters, we noted statistically significant discrepancies between workers employed at meatprocessing production and two other occupational groups. Workers employed at meatprocessing production had the most favorable conditions in terms of sanitary-hygienic provision (Table 2).

The biggest number of people who had medical examinations when being recruited was detected among workers employed at meat-processing production (53.2\%); the least number, among stock breeders $(4.5 \%)$.

Absence of preliminary medical examinations, and periodical ones being irregular and of low quality, as well as untimely appeal for medical aid prove that employers and employees have irresponsible medical behavior and the latter run behavioral risk factors as they do not attend occupational medical examinations [9]. 
Table 1

A fracture of impacts exerted by occupational factors on workers' modbidity and a degree of health disorders dependence on occupation (\%)

\begin{tabular}{|l|c|c|c|}
\hline \multicolumn{1}{|c|}{ Occupational factor } & Pathology & $\begin{array}{c}\text { Fracture of } \\
\text { impact, } \%\end{array}$ & $\begin{array}{c}\text { Degree of dependence on } \\
\text { occupation }\end{array}$ \\
\hline Unfavorable microclimate & Joint syndrome & $\begin{array}{c}78,7 \\
F=16,7 ; p<0,01^{*}\end{array}$ & Very high \\
\hline Unfavorable microclimate & $\begin{array}{c}\text { Vegetative-sensory poly- } \\
\text { neuropathy syndrome }\end{array}$ & $\begin{array}{c}80,9 \\
F=34,0 ; p<0,01 *\end{array}$ & Very high \\
\hline Labor intensity & Encephalopathy syndrome & $\begin{array}{c}62,1 \\
F=22,9 ; p<0,01 *\end{array}$ & Very high \\
\hline
\end{tabular}

Note: * means impact by an examined factor, which is statistically significant at $p<0.05$ (ANOVA); $F$ is Fischer criterion.

Table 2

Sanitary-hygienic and medical-preventive provision of workers

\begin{tabular}{|c|c|c|c|c|}
\hline \multirow[b]{2}{*}{ No. } & \multirow[b]{2}{*}{ Parameter } & \multicolumn{3}{|c|}{ Occupational group, \% } \\
\hline & & $\begin{array}{c}\text { Stock breeders } \\
\quad(n=67)\end{array}$ & $\begin{array}{l}\text { Veterinaries }(n= \\
73)\end{array}$ & $\begin{array}{l}\text { Workers em- } \\
\text { ployed at MPP } \\
\quad(n=62)\end{array}$ \\
\hline 1 & Territory being comfortable & $\begin{array}{c}11,2 \\
(p<0,0001) *\end{array}$ & $\begin{array}{c}25,4 \\
(p<0,0001) *\end{array}$ & 72,6 \\
\hline 2 & Centralized water supply & $\begin{array}{c}79,1 \\
(p=0,002) *\end{array}$ & $\begin{array}{c}73,9 \\
(p=0,0002) *\end{array}$ & 98,4 \\
\hline 3 & Hot water supply & $\begin{array}{c}67,2 \\
(p=0,0001) *\end{array}$ & $\begin{array}{c}87,7 \\
(p=0,2)\end{array}$ & 95,2 \\
\hline 4 & Disinfectants & $\begin{array}{c}11,9 \\
(p<0,0001) *\end{array}$ & $\begin{array}{c}16,5 \\
(p<0,0001) *\end{array}$ & 51,6 \\
\hline 5 & Shower cabins at working places & $\begin{array}{c}4,5 \\
(p<0,0001) *\end{array}$ & $\begin{array}{c}6,9 \\
(p<0,0001) *\end{array}$ & 93,5 \\
\hline 6 & Rooms for having meals & $\begin{array}{c}15,3 \\
(p<0,0001) *\end{array}$ & $\begin{array}{c}34,6 \\
(p<0,0001) *\end{array}$ & 96,7 \\
\hline 7 & Satisfactory amenity rooms & $\begin{array}{c}16,4 \\
(p<0,0001) *\end{array}$ & $\begin{array}{c}20,5 \\
(p<0,0001) *\end{array}$ & 82,3 \\
\hline 8 & $\begin{array}{l}\text { Tools for removal of abortus and } \\
\text { stillborn fetuses }\end{array}$ & $\begin{array}{c}16,4 \\
(p=0,01) *\end{array}$ & $\begin{array}{c}50,7 \\
(p=0,2)\end{array}$ & 38,7 \\
\hline 9 & $\begin{array}{l}\text { Centralized laundry of protective } \\
\text { clothing }\end{array}$ & $\begin{array}{c}0,0 \\
(p<0,0001) *\end{array}$ & $\begin{array}{c}16,4 \\
(p<0,0001) *\end{array}$ & 93,5 \\
\hline 10 & First aid kits & $\begin{array}{c}16,4 \\
(p<0,0001) *\end{array}$ & $\begin{array}{c}39,7 \\
(p=0,08)\end{array}$ & 56,5 \\
\hline 11 & Specialized burial grounds & $\begin{array}{c}32,8 \\
(p<0,0001) *\end{array}$ & $\begin{array}{c}76,7 \\
(p<0,0001) *\end{array}$ & 3,2 \\
\hline 12 & Cleaning agents & $\begin{array}{c}58,2 \\
(p=0,01) *\end{array}$ & $\begin{array}{c}57,5 \\
(p=0,01) *\end{array}$ & 80,7 \\
\hline 13 & Personal protection means & $\begin{array}{c}32,8 \\
(p=0,1) \\
\end{array}$ & $\begin{array}{c}19,2 \\
(p=0,001) *\end{array}$ & 48,4 \\
\hline 14 & Preliminary medical examinations & $\begin{array}{c}4,5 \\
(p<0,0001) *\end{array}$ & $\begin{array}{c}13,7 \\
(p<0,0001) *\end{array}$ & 53,2 \\
\hline 15 & Periodical medical examinations & $\begin{array}{c}58,2 \\
(p<0,0001) * \\
\end{array}$ & $\begin{array}{c}72,6 \\
(p=0,0001) *\end{array}$ & 98,4 \\
\hline
\end{tabular}

Note: * means discrepancies in comparison with workers employed at MPP are statistically significant $\left(\chi^{2}\right.$ criterion). 
As per data taken from cards of epizootologic-epidemiologic examination of a zoogenous disease nidus a number of infected people in occupational niduses varied from 2 to 5 people.

Observation of sanitary-epidemiologic regime at working places occupied by stock breeders, veterinaries, and workers employed at meat-processing production is given in the Table 3 .

Absence of disinfectants, cleaning agents, and first aid kits, absence of disinfection in a nidus and activities aimed at its elimination, absence of quarantine cause epidemiologic or disinfection risks [12].

The results given in the Tables 2-4 prove there are gross violations of sanitaryepidemiologic rules СП 3.1.7.2613-10 on brucellosis prevention [6].

The most probable factors for brucellosis infection catching are given in the Table 5.

$94.0 \%$ stock breeders, $89.0 \%$ veterinaries, and $83.9 \%$ workers employed at meatprocessing production had contacts with brucellosis-infected cattle. The rest of the examined workers had contacts with brucellosisinfected pigs and small cattle.

Table 3

Sanitary-epidemiologic regime observation

\begin{tabular}{|c|l|c|c|c|}
\hline \multirow{2}{*}{ No. } & \multicolumn{1}{|c|}{ Parameter } & \multicolumn{3}{|c|}{ Occupational group, \% } \\
\cline { 3 - 5 } & $\begin{array}{c}\text { Stock breed- } \\
\text { ers } \\
(n=67)\end{array}$ & $\begin{array}{c}\text { Veterinaries }(n= \\
73)\end{array}$ & $\begin{array}{c}\text { Workers em- } \\
\text { ployed at MPP } \\
(n=62)\end{array}$ \\
\hline 1 & $\begin{array}{l}\text { Laboratory examination of materials } \\
\text { taken from animals and from outer envi- } \\
\text { ronment }\end{array}$ & $80,6^{*}$ & $93,2^{*}$ & 50,0 \\
\hline 2 & Quarantine & 61,2 & 60,3 & - \\
\hline 3 & Vaccination of animals in a nidus & 29,9 & 46,6 & - \\
\hline 4 & $\begin{array}{l}\text { Slaughter of brucellosis-infected ani- } \\
\text { mals }\end{array}$ & $49,3^{*}$ & $71,2^{*}$ & 90,3 \\
\hline 5 & Disinfection in a nidus & - & $58,9^{*}$ & 83,9 \\
\hline 6 & Nidus elimination & 59,7 & 42,5 & - \\
\hline 7 & $\begin{array}{l}\text { Laboratory examination of people in- } \\
\text { fected with brucellosis }\end{array}$ & 94,0 & 97,3 & 53,2 \\
\hline 8 & $\begin{array}{l}\text { Number of patients who were vaccinat- } \\
\text { ed before the diseases }\end{array}$ & - & $2,7 *$ & 500,0 \\
\hline
\end{tabular}

Note: * means discrepancies in comparison with workers employed at MPP are statistically significant, $p<$ 0.05 .

Table 4

Violations of sanitary-epidemiologic regimes and rules that make for catching brucellosis

\begin{tabular}{|l|c|c|c|}
\hline \multirow{2}{*}{ Parameter } & \multicolumn{3}{|c|}{ Occupational group, \% } \\
\cline { 2 - 4 } & $\begin{array}{c}\text { Stock breeders } \\
(n=67)\end{array}$ & $\begin{array}{c}\text { Veterinaries }(n= \\
73)\end{array}$ & $\begin{array}{c}\text { Workers em- } \\
\text { ployed at MPP } \\
(n=62)\end{array}$ \\
\hline Animals keeping & 89,5 & 67,4 & - \\
\hline $\begin{array}{l}\text { Transportation, storage, and processing of stock- } \\
\text { breeding raw materials and other agricultural } \\
\text { products }\end{array}$ & - & - & 87,7 \\
\hline Agricultural and other works & 10,5 & - & - \\
\hline Slaughter, necropsy, skinning & - & $30,4^{*}$ & 12,3 \\
\hline Lambing & - & 2,2 & - \\
\hline
\end{tabular}

Note: * means discrepancies in comparison with workers employed at MPP are statistically significant $\left(\chi^{2}\right.$ criterion). 
The most probable factors which can cause catching brucellosis

\begin{tabular}{|l|c|c|c|}
\hline \multirow{2}{*}{\multicolumn{1}{|c|}{ Parameter }} & \multicolumn{3}{|c|}{ Occupational group, \% } \\
\cline { 2 - 4 } & $\begin{array}{c}\text { Stock breed- } \\
\text { ers } \\
(n=67)\end{array}$ & $\begin{array}{c}\text { Veterinaries }(n= \\
73)\end{array}$ & $\begin{array}{c}\text { Workers em- } \\
\text { ployed at MPP } \\
(n=62)\end{array}$ \\
\hline Stock-breeding raw materials and products & - & - & 88,7 \\
\hline Abortus fetuses, stillborn fetuses, and afterbirth & 36,8 & 58,9 & - \\
\hline Blood, urine, and other biological substrates & $\begin{array}{c}21,5(p= \\
0,18)\end{array}$ & $41,1 *$ & 11,3 \\
\hline Dung & 27,8 & - & - \\
\hline Milk and dairy products & 13,9 & - & - \\
\hline
\end{tabular}
terion).

Note: * means discrepancies in comparison with workers employed at MPP are statistically significant $\left(\chi^{2}\right.$ cri-

$16.4 \%$ stock breeders, $57.5 \%$ veterinary workers, and $22.6 \%$ workers employed at meatprocessing production were informed of a probability to be infected with brucellosis at their working place; the information came via three non-dialogue communicative models for spreading information on occupational health risks (limited parity, paternalistic, and formal one)

People infected with brucellosis were detected during prevention medical examination in $16.7 \%$ cases among stock breeders; in $13.7 \%$, among veterinaries; in $21.0 \%$, among workers employed at meat-processing production. As for the rest of the cases, brucellosis was diagnosed when a worker applied for medical aid.

Brucellosis was detected in $8.2 \%$ cases when veterinaries were examined as per epidemiologic reasons.

Time gaps between a start of the disease, brucellosis diagnosis, and correlation between the disease and an occupation, $M \pm s$

\begin{tabular}{|c|c|c|c|c|c|c|}
\hline \multirow{3}{*}{ Occupational groups } & \multicolumn{6}{|c|}{ Time gap } \\
\hline & \multicolumn{2}{|c|}{$\begin{array}{c}\text { Start of the disease and a } \\
\text { visit to a doctor }\end{array}$} & \multicolumn{2}{|c|}{$\begin{array}{l}\text { A visit to a doctor and } \\
\text { brucellosis diagnosis }\end{array}$} & \multicolumn{2}{|c|}{$\begin{array}{c}\text { Brucellosis diagnostics } \\
\text { and occupational disease } \\
\text { diagnostics }\end{array}$} \\
\hline & $\begin{array}{l}\text { Time gap, } \\
\text { years } \\
\text { (share of in- } \\
\text { fected, } \% \text { ) }\end{array}$ & $M \pm s$ & $\begin{array}{c}\text { Time gap, } \\
\text { years } \\
\text { (share of in- } \\
\text { fected, \%) }\end{array}$ & $M \pm s$ & $\begin{array}{l}\text { Time gap, } \\
\text { years } \\
\text { (share of in- } \\
\text { fected, } \% \text { ) }\end{array}$ & $M \pm s$ \\
\hline Stock breeders & $\begin{array}{c}7-15 \\
(59,7)\end{array}$ & $15,4 \pm 3,6$ & $\begin{array}{c}2-18 \\
(25,4)\end{array}$ & $12,9 \pm 1,9$ & $\begin{array}{c}2-31 \\
(64,2)\end{array}$ & $14,2 \pm 2,5$ \\
\hline Veterinaries & $\begin{array}{l}15-30 \\
(68,5)\end{array}$ & $11,5 \pm 2,3^{*}$ & $\begin{array}{c}2-38 \\
(56,2)\end{array}$ & $17,4 \pm 6,9 *$ & $\begin{array}{c}2-42 \\
(69,9)\end{array}$ & $11,7 \pm 2,1^{*}$ \\
\hline $\begin{array}{l}\text { Workers employed at } \\
\text { MPP }\end{array}$ & $\begin{array}{c}5-12 \\
(80,6)\end{array}$ & $7,4 \pm 1,7 * \wedge$ & $\begin{array}{c}2-34 \\
(96,8)\end{array}$ & $\begin{array}{l}15,9 \pm \\
1,7 * \wedge\end{array}$ & $\begin{array}{c}2-28 \\
(37,1)\end{array}$ & $\begin{array}{l}13,0 \pm \\
3,3 * \wedge\end{array}$ \\
\hline
\end{tabular}

Note: * means discrepancies in comparison with stock breeders; $\wedge$ means discrepancies in comparison with veterinaries are statistically significant (Student's $t$-criterion, $p<0.05$ ), material is given as average \pm standard deviation. 
Medical examinations were the most regular and qualitative in the group of workers employed at meat-processing production (as per $\chi^{2}$ data and Student's criterion).

Time gaps between the first visit to a doctor and up to the moment when brucellosis was diagnosed and a decision on occupational nature of the disease was taken are given in the Table 6.

Duration of contacts with infected animals or raw materials up to the moment when brucellosis was diagnosed amounted to 11-20 years for $38.6 \%$ patients, to more than 30 years for $21.4 \%$, less than 10 years for the rest.

Most examined workers $(69.3 \% ; n=140)$ applied for medical aid for the first time when 530 years had passed after the start of the disease and it proved their irresponsible medical behavior, high level of proneness to risk and selfdestruction (see Table 6). Time gap between a visit to a doctor and the moment when brucellosis was diagnosed amounted to 2-38 years for $58.4 \%(n=118)$. Even if Burnet sample was positive, brucellosis was diagnosed in $34.3 \%$ patients after 2-20 years, on average after $11.3 \pm$ 2.4 years. Time gap between the moment when brucellosis was diagnosed and detection of correlation between the disease and an occupation amounted to 2-42 years for $72.8 \%(n=147)$.

Late brucellosis diagnostics and late detection of correlation between the diseases and an occupation didn't allow to change a worker's employment rationally in due time and it caused re-infection, the disease growing graver, and even disability.

Conclusions. Late diagnostics of health disorders is the basic risk factor of brucellosis for workers employed at meat-processing production who have contacts with infected animals and raw materials. Reasons for late diagnostics are ignorance about possible brucellosis contagion at a working place; late appeal for medical health; rare preliminary medical examinations (in $4.5-13.7 \%$ of cases) and irregular periodical medical examinations $(62.7-$
$74.0 \%$ cases) organized by employers. Workers don't apply for medical aid and don't visit an occupational pathologist as they fear to lose their job and to be punished by their employers. Medical and preventive organizations don't provide the necessary quality of preliminary and periodical medical examinations. Late appeal for medical health results in clinical picture polymorphism and a patient has to be treated for a long time (years) visiting various doctors (surgeons, therapists, orthopedists, neurologists, vertebral pathologists, and rheumatologists).

Other substantial factors causing epidemiologic and disinfection risks (which could be partly called behavioral) detected in 67$100 \%$ of stock breeders and veterinaries were violations of anti-brucellosis regime made by workers themselves. There were no disinfectants and cleaning agents and/or first aid kits at working places. Absence of disinfection in niduses and no activities aimed at niduses elimination as well as absence of quarantine belong to the same group of factors.

There are additional parameters which make risks even worse; they are adverse occupational factors such as biological ones, vibrations and noise, cooling microclimate, ammonia, organic dust, uncomfortable lighting environment, labor hardness and intensity.

Besides, workers had to perform their job tasks with only short breaks or even without any fixed breaks; they often had to work overtime, and their vacations were irregular and too short. Therefore, organizational factors made their contribution into overall threats of workers' health disorders.

Absence and/or refusal to use personal protection means and personal hygiene means, working in a forced position together with significant physical strain and unfavorable working zone microclimate make a worker's organism more prone to the infection and make occupational brucellosis risk much higher. 


\section{References}

1. Borisov V.A. Sovremennoe sostoyanie problemy brutselleza [Contemporary state of brucellosis problem]. Zhurnal infektsionnoi patologii, 2000, vol. 7, no. 1-2, pp. 57-59 (in Russian).

2. Bukhtiyarov I.V., Rubtsov M.Yu. Cmennyi trud kak faktor kantserogennogo riska [Shift work as carcinogenic risk factor]. Mezhdunarodnyi nauchno-issledovatel'skii zhurnal, 2016, vol. 53, no. 11-3, pp. 134-137 (in Russian).

3. O merakh po realizatsii polnomochii Edinoi gosudarstvennoi Federal'noi tsentralizovannoi sistemy gosudarstvennogo sanitarno-epidemiologicheskogo nadzora $\mathrm{v}$ oblasti obespecheniya biologicheskoi $\mathrm{i}$ khimicheskoi bezopasnosti: postanovlenie glavnogo gosudarstvennogo sanitarnogo vracha Rossiiskoi Federatsii № 50 ot 04.08 .09 g. [On activities aimed at implementation of authority by Integrated State Federal Centralized System of state sanitary-epidemiologic surveillance in the sphere of providing biological and chemical safety: resolution by the RF Chief State Sanitary Inspector No. 50 dated August 04, 09]. Available at: https: //www.garant.ru/products/ipo/prime/doc/4089061/ (09.12.2016) (in Russian).

4. Orakbai L.Zh., Cherepanova L.Yu., Denisova T.G. Sovremennye aspekty epidemicheskogo protsessa brutselleza [Contemporary aspects of brucellosis epidemic process]. Sovremennye aspekty nauki i obrazovaniya, 2015, no. 6. Available at: https: //www.science-education.ru/ru/article/view? id = 22737 (25.05.2017) (in Russian).

5. Dobrokhotskii O.N., Mushchak I.P., Kirpichenkov A.B., Dyatlov I.A., Zar'kov K.A. Proektirovanie laboratorii - klyuchevoe zveno upravleniya bioriskami pri rabote s patogennymi biologicheskimi agentami [Designing of laboratories is crucial for the management of biorisks in the work with pathogenic biological agents]. Gigiena i sanitariya, 2014, vol. 93, no. 6, pp. 59-61 (in Russian).

6. Profilaktika brutselleza: Sanitarnye normy i pravila 3.1.7.2613-10 [Prevention of brucellosis: sanitary standards and rules 3.1.7.2613-10]. utv. postanovleniem Glavnogo gosudarstvennogo sanitarnogo vracha RF ot 26.04.2010 № 39 [approved by resolution by the RF Chief State Sanitary Inspector dated April 26, 2010 No. 39]. Available at: http: //89.rospotrebnadzor.ru/documents/ros/postanov/30197/ (09.12.2016) (in Russian).

7. Rukovodstvo po gigienicheskoi otsenke faktorov rabochei sredy i trudovogo protsessa. Kriterii i klassifikatsiya uslovii truda. R 2.2.2006-05. [Guide on Hygienic Assessment of Factors of Working Environment and Work Load. Criteria and Classification of Working Conditions]. Available at: http: //www.kadrovik.ru/docs/rukovodstvo.2.2.2006-05.htm (12.12.2016) (in Russian).

8. Rebrova O.Yu. Statisticheskii analiz meditsinskikh dannykh. Primenenie paketa prikladnykh programm STATISTICA [Statistic analysis of medical data. Use of STATISTICA applied software]. Moscow, Media Sfera Publ., 2002, 312 p. (in Russian).

9. Ryazanova E.A., Lebedeva-Nesevrya N.A. Riskovoe povedenie rabotnikov v sfere zdorov'ya kak faktor poter' trudovogo potentsiala promyshlennogo predpriyatiya [Workers' health risk behavior as a factor of labour potential losses of industrial enterprises]. Aktual'nye problemy razvitiya chelovecheskogo potentsiala $v$ sovremennom obshchestve. Institutsional'nye izmeneniya $v$ Rossii $i$ mire: Materialy Mezhdunarodnoi nauchno-prakticheskoi internet-konferentsii [Vital issues of human potential development in contemporary society. Institutional changes in Russia and worldwide: materials of the International theoretical and practical Internet-conference]. Perm', Permskii gosudarstvennyi natsional'nyi issledovatel'skii universitet Publ., 2015, pp. 13-16 (in Russian).

10. Ereniev S.I., Demchenko V.G., Plotnikova O.V., Safonov A.D., Rudakov N.V. Gordienko, L.N., Ponomareva O.G., Tarkhov A.E. Sanitarno-gigienicheskie i kliniko-immunologicheskie aspekty professional'nogo brutselleza v sovremennykh usloviyakh [Sanitary-hygienic and clinical-immunologic aspects of occupational brucellosis in contemporary conditions]. In: V.G. Demchenko, A.D. Safonova, N.V. Rudakova, S.I. Erenieva eds. St-Peterburg: TESSA Publ., 2014, 220 p. (in Russian).

11. Spirin V.F., Novikova T.A. Gigienicheskie aspekty upravleniya professional'nymi riskami u rabotnikov sel'skogo khozyaistva [Occupational risk control in rural workers: Hygienic aspects]. Zdravookhranenie Rossiiskoi Federatsii, 2008, no. 1, pp. 19-20 (in Russian).

12. Shestopalov N.V. Sovershenstvovanie dezinfektsionnoi deyatel'nosti i profilaktika infektsionnykh boleznei cheloveka [Совершенствование дезинфекционной деятельности и профилактика инфекционных болезней человека]. Meditsinskii alfavit, 2013, vol. 1, no. 5, pp. 5-7 (in Russian).

13. Rudakov N.V., Yastrebov V.K., Yakimenko V.V., Rudakova S.A., Samoilenko I.E., Poleshchuk 
E.M. Epidemiologicheskaya otsenka territorii riska zarazheniya naseleniya prirodno-ochagovymi i zoonoznymi infektsiyami v prigranichnykh regionakh Sibiri [Epidemiological evaluation of contagion risk of the population natural focal and zoonotic infections in the frontier regions of Siberia]. Dal'nevostochnyi zhurnal infektsionnoi patologii, 2015, no. 27, pp. 17-19 (in Russian).

14. Behavioral Risk Factor Surveillance System Questionnaire. Available at: http: //www.cdc.gov/brfss/questionnaires/pdf-ques/2014_brfss.pdf (09.12.2016).

15. Boschiroli M., Foulongne V., O'Callaghan D. Brucellosis: a worldwide zoonosis. Curr. Opin. Microbiol, 2001, vol. 4, no. 1, pp. 58-64.

16. Bricker B.J. PCR as a diagnostic tool for brucellosis. Vet. Microbiol, 2002, vol. 90, no. 1-4, pp. 435-446.

17. Almuneef M.A., Memish Z.A., Balkhy H.H., Alotaibi B. [et al]. Importance of screening household members of acute brucellosis cases in endemic areas. Epidemiol. Infect, 2004, vol. 132, pp. 533540 .

18. Mantur B.G., Amarnath S.K., Shinde R.S. Review of clinical and laboratory features of human Brucellosis. Indian J. of Medical Microbiology, 2007, vol. 25, no. 3, pp. 188-202.

19. Chowdhury P.P., Mawokomatanda T., Xu F. [et al.]. Surveillance for Certain Health Behaviors, Chronic Diseases and Conditions, Access to health Care, and Use to Preventive Health Services Among States and Selected Local Areas - Behavioral Risk Factor Surveillance System, United States, 2012. MMWR Surveil. Sum, 2016, vol. 65, no. SS-4, pp. 1-142.

20. Zheludkov M.M., Tsirelson I.E., Kulakov Y.K. Human brucellosis in Russia. Mater. Intern. Confer. Brucellosis, London, 2008, pp 125.

Ereniev S.I., Plotnikova O.V., Demchenko V.G., Rudakov N.V. Biological, epidemiological, sanitary-hygienic, medical and behavioral occupational health risk factors for stock-breeders, veterinaries and workers employed at meat-processing enterprises, contacting brucellar animals and infected meat. Health Risk Analysis, 2017, no. 2, pp. 94-103. DOI: 10.21668/health.risk/2017.2.11.eng

Received: 12.01 .2017

Accepted: 20.03 .2017

Published: 30.06 .2017 
UDC 616-036.22: 615.5

DOI: 10.21668/health.risk/2017.2.12.eng

\section{ANALYSIS OF RISK FOR INFECTIONS RELATED TO PROVIDING MEDICAL ASSISTANCE}

\section{G.G. Badamshina ${ }^{1}$, V.B. Ziatdinov ${ }^{1}$, G.Sh. Isaeva ${ }^{2}$, M.A. Kirillova ${ }^{1}$, S.S. Zemskova ${ }^{1}$}

${ }^{1}$ Center for hygiene and epidemiology in Republic of Tatarstan, 13a Sechenova Str., Kazan, 420061, Russian Federation ${ }^{2}$ Kazan scientific-research institute for epidemiology and microbiology, 67 Bol'shaya Krasnaya Str., Kazan, 420015, Russian Federation

Our research goal was to assess risks for infections related to providing medical assistance in places where air samples conform or don't conform to hygienic standards as per microbiological parameters. We performed bacteriological and mycological examination of air samples $(n=44)$ in a medical organization (inside it) in conformity with methodical guidelines "Techniques for sanitary-bacteriologic examination of environmental objects, air, and sterility control in medical organizations" and sanitary rules and standards "Sanitary-epidemiologic requirements to organizations dealing with medical activities". We identified all types of microorganisms detected in air samples using conventional microbiological techniques. Bacteria belonging to 3 families, 4 stems, and 7 species, were detected in samples deviating from standards; bacteria of 7 families, 9 stems, and 12 species, were detected in samples conforming to standards. We found a great species variety of molds and bacteria such as staphylococcus spp., Micrococcus spp., Acinetobacter spp., Neisseria spp., Pausterella spp., Stenotrophamonas spp., which were considered to be conditionally pathogenic and causing infections related to providing medical assistance. We calculated relative risks parameters for infections caused by various microorganisms. We revealed that risks for infections caused by staphylococcus were higher in rooms where air samples didn't conform to sanitary-hygienic standards than in "clean rooms" (RR=2.1; OR=3.6). Risks for infections caused by micrococcus and molds were still substantially high both in "clean" rooms and in rooms where air samples didn't conform to sanitary-hygienic standards (). All this makes it absolutely necessary to improve activities aimed at monitoring infections related to providing medical assistance and caused by bacterial and mycotic agents as well as to develop existing hygienic standards and to apply new advanced disinfectants.

Key words: microflora, air, microbiological monitoring, relative risk, conditionally pathogenic microorganisms, bacteria, infections, related to providing medical assistance, hygienic standardization

Hospital environment is one of the most favorable for colonization of air and environmental objects with conditionally pathogenic and pathogenic microorganisms $[10,11]$. Via airborne, community-acquired, fecal-oral routes and transmissions, causative agents of infectious diseases get into environment of medical organizations from patients [10]. Ac- cumulation and circulation of microorganisms in the air and on the objects of medical premises can subsequently become a source of healthcare-associated infections (HAI) $[1,3$, $10,13]$.

According to recent data, in the structure of HAI causative organisms of bacterial nature, the conditionally pathogenic and rare-

(C) Badamshina G.G., Ziatdinov V.B., Isaeva G.Sh., Kirillova M.A., Zemskova S.S., 2017

Gulnara G. Badamshina - Candidate of Medical Sciences, Head of microbiological research department (email: ggbadamshina@yandex.ru; tel.: +7 (843) 221-79-58).

Vasil B. Ziatdinov - Doctor of Medical Sciences, Professor, Head physician (e-mail: fguz@16.rospotrebnadzor.ru; tel.: +7 (843) 221-90-90).

Guzel Sh. Isaeva - Doctor of Medical Sciences, Director (e-mail: guzelleisaeva@ yandex.ru; тел.: +7 (843) 236-67-21).

Mariya A. Kirillova - a biologist at bacteriological research laboratory (e-mail: mashkir.2015@bk.ru; tel.: +7 (843) 221-79-58).

Svetlana S. Zemskova - a biologist at bacteriological research laboratory (e-mail: zemskova_svetlana@mail.ru; tel.: +7 (843) 221-79-58). 
ly pathogenic microflora is prevalent. References are made more often to gram-positive flora of Staphylococcus, Streptococcus, Enterococcus, Bacillus, Clostridium Staphylococcus, Streptococcus, Enterococcus, Bacillus, Clostridium stem [5, 6, 8, 11, 13, 14], gram-negative flora of Enterobacteriacea family, non-fermentative bacteria of Pseudomonas, Acinetobacter stem [4, 7, 11, 12, 15-17], yeast and molds [13] and viruses, particularly B, C, D hepatitis viruses, noroviruses, respiratory syncitial viruses, rhinoviruses, coronaviruses, adenoviruses, enteroviruses and others $[9,10]$. The up-to-date Russian practical policies do not regulate content of the above kinds of microorganisms under the existing sanitary rules and hygienic standards. Methodological guidelines do not specify techniques for isolating and identifying certain types of nosocomial infections pathogens from environmental objects. However, ambient air in medical organizations, being in compliance with the sanitary rules and regulations 2.1.3.2630-10 "Sanitary-epidemiologic requirements to organizations dealing with medical activities" may be contaminated with HAI pathogens in amounts below the maximum permissible values.

Research goal was to assess risks for infections related to providing medical assistance in places where air samples conform or don't conform to hygienic standards as per microbiological parameters.

Materials and methods. We performed air sampling $(n=44)$ from January to December 2016, before and during the working hours, according to the methodological guidelines MUK 4.2.2942-11 "Techniques for sanitary-bacteriologic examination of environmental objects, air, and sterility control in medical organizations ". In medical treatment and procedural rooms, the total bacterial contamination of air or the total microbial count (MBC) was determined. The obtained values of air MBC were compared with the values established in Appendix 3, SanPiN 2.1.3.263010 "Sanitary-epidemiologic requirements to organizations dealing with medical activities".
We carried out complete identification of microorganisms up to species using the advanced chromogenic nutrient media made in India and Spain, biochemical tests of Czech and France production with Multiscan analyzer.

The obtained results were processed applying methods of parametric and nonparametric statistics using Microsoft Excel software package. With values normal distribution in uniform arrays of the set sampling, we determined mean values $(M)$ and standard error of the mean $(m)$ to estimate the number of microorganisms in $1 \mathrm{~m}^{3}$ of air, with the significance of difference estimated by Student's criterion $(t)$. In the absence of the normality of distribution law in effect, taking into account small sample for the research $(n<30)$, we used Mann-Whitney (U) criterion to compare the prevalence of different microorganisms in the air. The differences were considered reliable at a significance level of $p<0.05$.

On the ground of the previous studies, direct correlation was found between total air contamination and HAI incidence rates in patients of healthcare institutions in the Republic of Tatarstan [2]. In this regard, the probability (risk) for progressing infections related to providing medical assistance is established based on the calculation of relative risk (RR) and odds ratio (OR).

Results and discussion. Based upon results of an in-depth microbiological study of air and swabs, it was found that $27.3 \%$ of samples did not meet sanitary and hygienic standards. Thus, the mean MBC value in nonstandard samples (incompliant with sanitary and hygienic standards) was $400.0 \pm 85.2$ $\mathrm{CFU} / \mathrm{cm}^{3}$; The mean $\mathrm{MBC}$ value in standard samples (compliant with standards) was 115.0 $\pm 27.9 \mathrm{CFU} / \mathrm{cm}^{3}$. At the same time, there were no significant differences revealed in MBC level.

Complete identification of microorganisms showed wide variety of species in the studied samples (please, see Fig.). We established that in the air samples corresponding to sanitary and hygiene standards, there was a wider species diversity of microorganisms. Thus, in the non-standard samples, bacteria of 


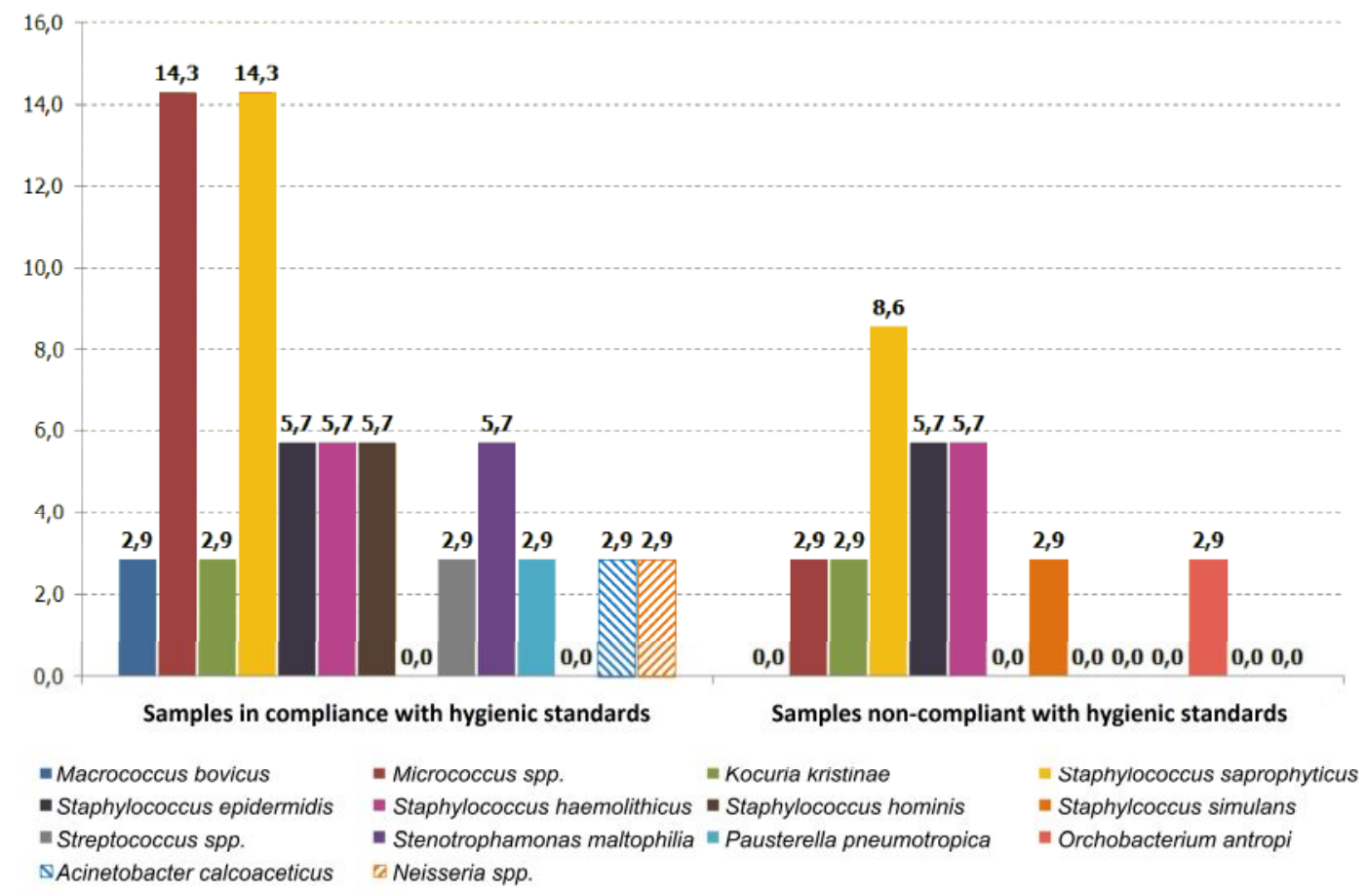

Fig. Air samples contamination with microorganisms in medical organization (\%)

3 families, 4 stems, and 7 species were detected; in the samples conforming to the standards, 7 families, 9 stems, 12 species. To assess the risk for developing infections related to providing medical assistance from different microbial genera, we compared bacterial and fungal prevalence rates in rooms where air samples conformed and did not conform to sanitary and hygienic standards as per microbiological parameters.

Comparing the indices of air contamination in standard and non-standard samples, we noted statistically significant differences in the mean value of staphylococci $(20.4 \pm 6.1 \%$ and $38.6 \pm 7.4 \%$, respectively, $p<0.05)$ and micrococci $(47.5 \pm 7.6 \%$ and $26.0 \pm 6.8 \%, p$ $<0.05)$. The comparative assessment of air contamination with staphylococci did not reveal any statistically significant differences.

Attention is drawn to the fact that in the organized bandaging rooms of surgery department, the purulent surgery suite, the small operating examination room, the manipulative female consultation department, from the air of "clean" rooms there were detected: Micrococcus spp. in amounts of 5 to $100 \mathrm{CFU} / \mathrm{cm}^{3}$, including $\mathrm{Ko}$ curia kristinae $(12.5 \pm 5.0 \%)$; Staphylococcus of various species in the amounts of 5 to 80
$\mathrm{CFU} / \mathrm{cm}^{3}(267.0 \pm 32.2 \%$ and $150.0 \pm 13.2 \%$ respectively, considering two types of staphylococci and more present in one sample); Stenotrophamonas maltophilia in the amount of 10 $\mathrm{CFU} / \mathrm{cm}^{3}(25.0 \pm 6.6 \%)$; Acinetobacter calcoaceticus in the amount of $30 \mathrm{CFU} / \mathrm{cm}^{3}(12.5 \pm$ $5.0 \%)$; Neisseria flava in the amount of 30 $\mathrm{CFU} / \mathrm{cm}^{3}(12.5 \pm 5.0 \%)$. Also various species molds were found in the amounts from 20 to 340 $\mathrm{CFU} / \mathrm{cm}^{3}(50.0 \pm 7.6 \%)$. All this can cause infectious and allergic diseases $[1,7,13,16]$.

While working with a patient in the hospital at various locations, such as: surgery suite, intensive care unit and resuscitation, operating clinics and surgical room, in the air compliant with the sanitary and hygienic standards by MBC level, we found Staphylococcus of various types (16 cases), Streptococcus spp. (4); Stenotrophamonas maltophilia (4); Macrococcus bovicus (2); Pausterella pneumotropica (2) and molds (4) [6].

When calculating the risk indices for infections associated with providing medical assistance, it's established that probability of contamination with staphylococci in rooms where air samples do not meet sanitary-hygienic standards is higher than in rooms where air is considered as "relatively clean ". This corresponds to the 
data obtained earlier, and the standard values approved in sanitary regulations. Thus, the probability of HAI due to $S$. saprophythicus, $S$. haemolithycus, S. epidermidis in "infectious" rooms is higher than in "clean" ones, as evidenced by the values of $R R=2.1$ (CI 0.8-4.2) and $O R=3.6$ (CI 0.7-18.0).

The probability for infectious process development due to micrococci is still high also in the premises subject to strict requirements to air quality. So, before starting patient treatment in surgery department bandaging rooms and in small operating examination room, where the air samples complied with sanitary and hygiene standards, the risk for developing HAI due to Micrococcus spp. was $R R=1.2$ (CI 0.4-3.1) and $O R=1.3($ CI 0.3-6.3). The same risk ratio was established during operations in the surgery room, in the intensive care unit, in the surgery room at polyclinic.

The higher contamination risk in "clean" rooms is also indicated by the high air contamination with Stenotrophamonas maltophilia and Acinetobacter calcoaceticus. This bacteria's presence was recorded prior to starting work in a relatively safe air environment in the rooms prepared for operations - the manipulative female consultation and surgery room. The high probability of HAI caused by micromycetes is indicated by mold present in the air of the vaccination room prior to work, which can be related either to the lack of sanitary and antiepidemic activities, or the inefficiency of disinfection $[1,3]$.

Conclusions. The relative risk for HAI developing from Staphylococcus spp. in the rooms where air samples do not meet sanitary and hygienic standards is higher than in "clean rooms" $(R R=2.1(\mathrm{CI} 0.8-4.2)$ and $O R=3.6$ (CI 0.7-18.0).

We noted dangerous tendencies to the formation of risk for HAI developing from $\mathrm{Mi}$ crococcus spp. both in "clean" rooms, as well as and in the rooms where air samples do not meet sanitary and hygienic standards $(R R=1.2$ (CI 0.4-3.1) and $O R=1.3$ (CI 0.3-6, 3)).

The relative risk for HAI developing due to mold is high both in the rooms with safe air, and in the rooms where air does not meet sanitary and hygienic standards requirements $(R R=$ 0.5 (CI 1.0-1.94), OR=0.1 (CI 0.7-4.5)).

The obtained results dictate the need to improve the existing hygienic standards and to apply new advanced disinfectants.

\section{References}

1. Gabrielyan N.I., Gorskaya E.M., Romanova N.I., Saitgareev R.Sh. Vneshnyaya sreda khirurgicheskoi kliniki i vnutribol'nichnye infektsii (sostoyanie voprosa) [Outer environment of a surgical clinic and hospital-acquired infections (contemporary situation)]. Meditsinskii alfavit, 2015, vol. 1, no. 6, pp. 7-12 (in Russian).

2. Zaripova A.Z., Badamshina G.G., Ziatdinov V.B., Isaeva G.Sh.Regional'nye osobennosti zabolevaemosti infektsiyami, svyazannymi s okazaniem meditsinskoi pomoshchi [Regional peculiarities of incidence of infections associated with health care]. Prakticheskaya meditsina, 2016, vol. 97, no. 5, pp. 7-11 (in Russian).

3. Orlova O.A., Efremova N.P., Akimkin V.G., Chistova A.V. Struktura i klinikoepidemiologicheskaya kharakteristika infektsii, svyazannykh s okazaniem meditsinskoi pomoshchi, $\mathrm{v}$ khirurgicheskikh statsionarakh Structure and clinical-epidemiologic characteristics of infections related to providing medical assistance, in surgical in-patient clinics. Meditsinskii alfavit, 2014, vol. 2, no. 10, pp. 14-19 (in Russian).

4. Hu Y., Ping Y., Li L., Xu H., Yan X., Dai H. A retrospective study of risk factors for carbapenem-resistant Klebsiella pneumoniae acquisition among ICU patients. The Journal of Infection in Developing Countries, 2016, vol. 10, no. 3, pp. 208-213. DOI: 10.3855/jidc.6697.

5. Al-Charrakh A.H., Al-Awadi S.J., Mohammed A.S. Detection of Metallo- $\beta$-Lactamase Producing Pseudomonas aeruginosa Isolated from Public and Private Hospitals in Baghdad. Acta Med Iran, 2016, vol. 54, no. 2, pp. 107-113.

6. Harris L.G., Murray S., Pascoe B., Bray J., Meric G., Magerios L., Wilkinson T.S., Jeeves R., Rohde H., Schwarz S., de Lencastre H., Miragaia M., Rolo J., Bowden R., Jolley K.A., Maiden M.C., 
Mack D., Sheppard S.K. Biofilm Morphotypes and Population Structure among Staphylococcus epidermidis from Commensal and Clinical Samples. PLoS One, 2016, vol. 11, no. 3, pp. e0154510.

7. Montagu A., Joly-Guillou M.L., Guillet C., Bejaud J., Rossines E., Saulnier P. Demonstration of the interactions between aromatic compound-loaded lipid nanocapsules and Acinetobacter baumannii bacterial membrane. International Journal of Pharmaceutics, 2016, vol. 506, no. 1-2, pp. 280-288.

8. Blaschitz M., Lepuschitz S., Wagner L., Allerberger F., Indra A., Ruppitsch W., Huhulescu S. Draft Genome Sequence of a Vancomycin-Resistant and Vancomycin-Dependent Enterococcus faecium Isolate. Genome Announc, 2016, vol. 4, no. 2, pp. 1-2. DOI: 10.1128/genomeA.00059-16.

9. Drysdale S.B., Green C.A., Sande C.J. Best practice in the prevention and management of paediatric respiratory syncytial virus infection. Therapeutic Advances in Infectious Disease, 2016, vol. 3, no. 2, pp. 63-71. DOI: 10.1177/2049936116630243.

10. Cavari Y., Kaplan O., Zander A., Hazan G., Shemer-Avni Y., Borer A. Healthcare workers mobile phone usage: A potential risk for viral contamination. Infectious Diseases, 2016, vol. 48, no. 6, pp. 432-435. DOI: 10.3109/23744235.2015.1133926.

11. Mirhoseini S.H., Nikaeen M., Shamsizadeh Z., Khanahmad H. Hospital air: A potential route for transmission of infections caused by $\beta$-lactam-resistant bacteria. American Journal of Infection Control, 2016, vol. 44, no. 8, pp. 898-904.

12. Sadeghi P., Khosravi A.D., Shahraki A.H., Beiranvand M. Identification of clinical isolates of Acinetobacter baumannii from Iran and study of their heterogeneity. Journal of the Chinese Medical Association, 2016, vol. 79, no. 7, pp. 382-386.

13. Sahu M.K., Siddharth B., Choudhury A., Vishnubhatla S., Singh S.P., Menon R., Kapoor P.M., Talwar S., Choudhary S., Airan B. Incidence, microbiological profile of nosocomial infections, and their antibiotic resistance patterns in a high volume. Annals of Cardiac Anaesthesia, 2016, vol. 19, № 2, pp. 281-287.

14. Finnerty C.C., Herndon D.N., Lee J.O., Rodriguez N.A., Al-Haj I.H., Wurzer P., Calhoun B.R., Jeschke M.G. Morbidity and mortality in severely burned children with Clostridium difficile-associated diarrhea. Surgery, 2016, vol. 159, no. 6, pp. 1631-1637.

15. Yoshino Y., Nakazawa S., Otani S., Sekizuka E., Ota Y. Nosocomial bacteremia due to Kluyvera cryocrescens: Case report and literature review. ID Cases, 2016, vol. 4, pp. 24-26.

16. Kishii K., Kikuchi K., Tomida J., Kawamura Y., Yoshida A., Okuzumi K., Moriya K. The first cases of human bacteremia caused by Acinetobacter seifertii in Japan. J. Infect. Chemother, 2016, vol. 22, no. 5 , pp. 342-345.

17. Veraldi S., Nazzaro G. Skin ulcers caused by Serratia marcescens: three cases and a review of the literature. European Journal of Dermatology, 2016, vol. 26, no. 4, pp. 373-376.

Badamshina G.G., Ziatdinov V.B., Isaeva G.Sh., Kirillova M.A., Zemskova S.S. Analysis of risk for infections related to providing medical assistance. Health Risk Analysis, 2017, no. 2, pp. 104-108. DOI: 10.21668/health.risk/2017.2.12.eng

Received: 22.01 .2017

Accepted: 12.05 .2017

Published: 30.06.2017 
UDC 613.644:612.842.5

DOI: 10.21668/health.risk/2017.2.13.eng

\title{
PECULIARITIES OF ADAPTATION REACTIONS IN FEMALE MIGRANTS AND HEALTH DISORDERS RISKS OCCURING AFTER DIFFERENT PERIODS OF STAYING ON MOSCOW REGION TERRITORY
}

\author{
N.F. Izmerov, N.I. Izmerova, I.V. Bukhtiyarov, M. Khodzhiev
}

Scientific Research Institute for Labor Medicine, 31 Budennogo Av., Moscow, 105275, Russian Federation

The article gives the results of determining peculiarities which are characteristic for adaptation in female migrants depending on a period of their staying in Moscow region. Adaptation was assessed as per variants of functional stress status and functional abilities of circulatory system. We detected that female migrants during their adaptation to impacts exerted by neuro-emotional factors, social-psychological factors, and physical (muscular) loads which varied in their intensity and length, had signs of stress syndrome. This syndrome was apparent through physiological parameters, namely increase in index of functional changes in circulatory system, and changes in heart rate variability as per regulatory systems activity parameter (PARS).

If female migrants stayed in Moscow region for less than 3 years than the most specific weight of migrants with unsatisfactory adaptation was detected among Russians and it was equal to 36.04\%; adaptation mechanisms were strained among Tadjiks women (62.08\%). If they stayed for longer than 3 years, then unsatisfactory adaptation parameter grew among Tadjiks women by $12.4 \%$ and it indicated that the body's functional reserves were mobilized and it could lead to adaptation failure. When adaptation was satisfactory, $\beta$-adrenoactivity of erythrocytes membranes was within the physiological changes standards regardless of a period of staying. When adaptation mechanisms were strained and adaptation itself was unsatisfactory, the greatest growth in this parameter was detected among Tadjiks women in any period of staying.

Preservation of female labor migrants health and prolongation of their working capacity period requires a system of medical and social support. Activities aimed at primary prevention of health disorders should include general physical training, tempering, autogenous training, and elimination of hazardous communal and occupational risk factors. Secondary prevention activities are systematic medical surveillance over migrants' health, including preliminary and periodic medical examinations.

Key words: adaptation, female migrants, period of staying, Moscow region, risks prevention, circulatory system, heart rate variability.

Today the International Organization for Migration committee has data on about 300 million migrants all over the world (3\% of the total world population). As per data given by the Federal Migration Service, 9.2 million migrants were in the Russian Federation territory in 2015 ; 5.2 million of them registered them- selves, found a job and a place to live permanently. Quantity of migrants is going to grow in the nearest future. About three quarters of the total labor migration are labor migrants who come to Russia from the CIS countries. The migration problem is vital for the Russian Federation as our country remains one of the

(C) Izmerov N.F., Izmerova N.I., Bukhtiyarov I.V., Khodzhiev M., 2017

Nikolay F. Izmerov - Member of the Russian Academy of Sciences, Doctor of Medical Sciences, Professor, Scientific Supervisor.

Natalia I. Izmerova - Doctor of Medical Sciences, Professor, Head of the Department (e-mail: niimt@niimt.ru; tel.: +7 (495) 365-21-84).

Igor' V. Bukhtiyarov - Director, Head of Laboratory for Labor Physiology and Preventive Ergonomics, Doctor of Medical Sciences, Professor, a Corresponding Member of the Russian Academy of Sciences (e-mail: niimt@ niimt.ru; tel.: +7 (495) 365-02-09).

Makhmadamin Khodzhiev - Candidate of Medical Sciences, working for a doctor's degree (e-mail: amin.dok@mail.ru; tel.: +7 (968) 585-12-95). 
most economically developed one among postSoviet states, and social and political situation in it is stable. And also there is demand for additional labor resources in Russia [9]

"Migration" and "adaptation" concepts are very close in many aspects. The very situation of changing a place of long-term (or even permanent) residence requires adaptation to new conditions, as well as partial or total integration into new environment $[1,2,5,16,17$, 18]. Poor knowledge of a language, laws, and existing behavioral patterns, differences in values and goal-settings etc. lead to stress evolvement both for migrants themselves and for a territory which accepts them [11, 13-17].

There are other stress-causing factors which can be related to social aspects or occupational environment and labor process; each such factor can appear in case of migrants involved in various labor processes. Thus, social status of many migrants is substantially lower than that they used to have in their home country. Immigrants often can get only unskilled jobs on the Russian labor market which are practically of no interest to local population [5, 6]. It is often next to impossible to find a fulltime job. Consequently, a number of research revealed that only $43.55 \%$ female migrants had regular jobs. A number of migrants actively involved in various labor processes goes down by the end of the third year of their staying in a receiving country regardless of their sex; it proves there are difficulties that migrants have in adapting to a new environment [7]. Migrants-refugees from hot points and places where nationalistic and ethnic conflicts appear are the most poorly adapted to living in new conditions in Russia [5, 13, 14]

But still labor migrants from former USSR republics are in high demand in a number of labor spheres. Women as a rule are employed in social services (as child-minders, as nurses for old people and disabled people). The results of the research performed by Marketing Research Center in $2013^{1}$, revealed that female migrants involved in housekeeping had a very closed lifestyle and it made their adaptation and integration very difficult and complicated. About one third of them (33\%) contacted migrants more often than local population [11]. And as their communication was limited to their families and countrymen it led to psychological and social complications.

This problem is not exclusively Russian. Scientists all over the world examine how depression and stresses in migrants evolve and how to prevent them [13-18]. For example, E. Hansen et al. (2003) detected that each forth farmer-migrant in the USA had one or several psychological disorders such as stress, depression, or anxiety. The situation of migration itself stimulates stresses especially in cases when migration is forced; it determines the necessity to detect basic health risk factors and to search for mechanisms of adaptation to new life and working conditions.

The latter determined our research goal which was to reveal peculiarities of adaptation process in female migrants on the basis of quantitative estimation of physiological costs which they had to bear in labor processes with substantial physical and neuro-emotional loads in order to work out prevention activities of medical and social support.

Data and methods. To study adaptation mechanisms, we examined women of fertile age (20-39) from three groups (Russians, Armenians, Tadjiks) with different period of staying on Moscow region territory: less than 3 years and longer than 3 years. Women worked in social services sphere as housemaids, nurses, and child-minders; they were examined allowing for impacts exerted by labor process factors and levels of physical and neuro-emotional loads.

A complex examination of migrants as per a conventional scheme was performed in Migration Service Center, Moscow regional office, and included medical documents analysis and questioning. To perform physiological research, we chose practically health people as

\footnotetext{
${ }^{1}$ Materials of the research performed by Marketing Research Center «Housekeeping workers in Russia and Kazakhstan», supported by the UN in 2013.
} 
per data of preliminary medical examinations. Our research included job analysis allowing for labor hardness and labor intensity in conformity with P 2.2.2006-05 [12]. Physiological research was aimed at studying neuromuscular system functional state as per arm and backbone dynamometry parameters (strength, endurance, and maximum muscular capacity). Besides, physiological research included standard comparative analysis of heart rate variability [4], blood pressure measuring, heart rate, index of functional changes in circulatory system as per R.M. Baevskiy [10]. The obtained physiological research results were assessed in conformity with methodical guidelines on physiological standards of a human body stress [8] and methodical guidelines by R.M. Baevskiy on heart rate variability analysis [4].

Adaptation reactions were studied on the basis of physiological techniques with detecting index of functional changes in circulatory system and special examination of $\beta$ adrenoreactivity of blood erythrocytes membranes. Three different states were outlined: satisfactory adaptation, adaptation mechanisms strain, and unsatisfactory adaptation.

Social conditions were assessed with the use of WHO questionnaire adapted for the tasks set by our research. The obtained data were processed with the use of Statistika software package.

Results and discussion. Job analysis revealed that female migrants working as housemaids had the following most substantial factors which made their labor hard: a lot of stereotype movements, working posture (which was uncomfortable for up to $50 \%$ of the total working time), body bendings (up to 300 during a working shift), movement in space (up to $12 \mathrm{~km}$ ). The overall housemaids labor assessment allowed to rank it as having 3.2 hazard class. As for nurses, the most adverse labor factor for them was a lifted cargo mass (up to $65 \mathrm{~kg}$ ), and their labor conditions class as per labor hardness was also 3.2. Total cargo sum which was moved during each hour of a working shift was the most adverse labor factor for child-minders, and overall labor hardness for them was assessed as 3.2.
Neuro-emotional loads for female migrants were determined by psychophysiological peculiarities of labor within "human - human" system where labor of the first group was aimed at serving the needs of the second one. All the occupational groups of female migrants had such factors in their labor intensity (class 3.2) as emotional loads related to responsibility for other people's safety, significance of any mistake, a quantity of conflicts arising out of their job responsibilities, and regime loads related to irregular working hours, absence of days off and holidays, and necessity to work at night.

Job social and psychological factors reflect interactions between working environment, job itself, working conditions, and those abilities, needs, and culture which a worker has, as well as his or her personal relations outside a job which can influence his or her health, work efficiency, and job satisfaction.

Harassment as behavior which violates personal privacy of a worker is rather new for our country; it has been taken from the AngloSaxon countries legislation. Such behavior can include jokes, hints, obtrusive molesting, threats, etc. The US legislative system has certain peculiarities due to which a company and not a supervisor (worker) who committed illegal actions acts as a defendant in court cases related to complaints about harassment. Companies usually wish to avoid publicity and reputation losses so they prefer to pay compensations to a victim rather then lose their clients' respect. According to several authors, a concept of harassment and its difference from just simple courtship is determined by social and psychological perceptions which differ from country to country [3].

Questioning results revealed quite rare cases $(3-5 \%)$ of harassment, and their quantity was equal both for female migrants and local people in Moscow region. About $77 \%$ women never faced harassment.

Questioning results were used to assess frequency of psycho-social factors which caused job stress. Prevalence of job stress factors at jobs with high neuro-emotional loads turned out to be quite apparent. Long irregular working hours 
were a typical feature of working life mentioned by workers from all occupational groups; it led to low job satisfaction.

Such job demands as fast working tempo, and absence of freedom (constant control over job techniques and quality, its rate, an order of actions in which a task was performed) were widely spread among social workers and amounted to $36.67 \pm 7.97 \%$ cases (class 3.2). Poor career development prospects were detected for female migrants working as nurses and child-minders.

When being questioned, workers from all occupational groups whose labor involved high neuro-emotional loads mentioned the necessity to focus their attention, to percept information quickly and precisely, to remember a great volume of information by ear and visually, to perform several activities simultaneously. Working under disturbances (35.0\% positive answers) turned out to be most typical for females working as childminders. Questioning results revealed a big share of people complaining on job stress. Stress situations occurred weekly, $38.9 \%$ of social sphere workers mentioned they had them several times a week. Unfavorable interpersonal relations in a team should be mentioned among factors determining low job satisfaction.

Physiological research performed on female labor migrants included examining neuromuscular system functional state as it was occupationally vital in providing job reliability of all the studied occupational groups. Examination of neuro-muscular system functional state in working day dynamics revealed that maximum strength of a right working arm tended to decrease by the end of a working shift in comparison with its beginning. Endurance to a statistic effort authentically decreased by the end of a working day in comparison with the value before it started. We detected $29.3 \%$ decrease in housemaids and nurses, and $28.2 \%$ in childminders $(p \leq 0.05)$. Statistically significant decrease in maximum muscular capacity was detected even after 4 hours of work, and by the end of a working day this decrease amounted to
$34.0 ; 28.9 ; 31.0 \%$ of the value at its beginning correspondingly.

The expressed static strain in lumber region muscles caused by performing job tasks in an uncomfortable position (which was with $45^{\circ}$ bending angle) by females employed in social sphere became apparent also in negative dynamics of backbone dynamometry parameters. Migrants working as housemaids had $49.7 \%$ decrease in maximum backbone muscles capacity from the initial value by the end of their working day; nurses, $35.3 \%$ decrease; child-minders, $32.7 \%(p \leq 0.05)$.

The detected changes in dynamometry parameters in a shift dynamics and physiological changes value prove that strain and overstrain evolve in neuro-muscular system of female migrants' arms and backbone muscles. The first strain signs occur already after 4 hours of work. By the end of a working day neuromuscular system strain is greatly evident.

The performed research results allowed us to detect a dependence between labor hardness and intensity and features of blood pressure changes and heart rate changes. Functional changes index assessment and its average values over a shift proved that great functional changes values were detected among female migrants under explicit labor loads. Thus, average functional changes index values over a shift amounted to $3.12 \pm 0.07$ points in nurses and to $3.20 \pm$ 005 points in child-minders. Practically the same values were observed in housemaids. Decrease in functional abilities of the circulatory system and unsatisfactory adaptation in female migrants were detected in stressful working hours and by the end of a working shift.

The results of heart rate variability research revealed sufficient adaptation processes strain in female migrants as per regulatory systems activity parameter (PARS). Thus, female migrants employed in social sphere had this parameter varying within $4.74 \pm 0.54-5.85 \pm 0.64$ arbitrary units. It proved apparent strain in regulatory systems caused by active mobilization of protection mechanisms including increase in sympathicoadrenal section activity.

Results of studying peculiarities of female migrants adaptation to living environment re- 
vealed that all the examined women were at various adaptation stages. These peculiarities depended on how long women lived on the examined territories. If they stayed on an ecologically adverse territory for less than 3 years, the greatest specific weight of female migrants with unsatisfactory adaptation was detected among Russians (36.04\%); and body adaptation capabilities decreased drastically among Tadjiks, which led to $62.08 \%$ growth in number of people with adaptation mechanisms strain. Armenian females were better adapted to living conditions on the examined territories (table).

Table

Number of women (\%) with various body adaptation capabilities in case they stayed for 0 to 3 years in Moscow regions

\begin{tabular}{|l|c|c|c|}
\hline \multirow{2}{*}{ Migrants group } & \multicolumn{3}{|c|}{ Adaptation level } \\
\cline { 2 - 4 } & Satisfactory adaptation & $\begin{array}{c}\text { Adaptation mechanisms } \\
\text { strain }\end{array}$ & Unsatisfactory adaptation \\
\cline { 2 - 4 } & $(1)$ & $(2)$ & $(3)$ \\
\hline Russians & $23,95 \pm 3,42$ & $40,01 \pm 1,38^{*}$ & $36,04 \pm 2,05^{*}$ \\
\hline Armenians & $26,83 \pm 2,58$ & $41,45 \pm 1,88 *$ & $31,72 \pm 3,0$ \\
\hline Tadjiks & $14,70 \pm 1,69$ & $62,08 \pm 1,38^{* *}$ & $23,22 \pm 3,11^{*}$ \\
\hline
\end{tabular}

Note : $* p \leq 0.05 ; * * p \leq 0.001-$ statistically authentic changes in comparison with (1).

When we examined women who stayed on the examined territory for longer than 3 years we revealed the common trend of increase in number of people with satisfactory adaptation to living environment. A number of people with adaptation mechanisms strain among Tadjiks females decreased two times in comparison with women who stayed on the examined territory for less than 3 years. But still unsatisfactory adaptation among female Tadjiks increased by $12.4 \%$ in comparison with women who stayed on the examined territory for less than 3 years and it indicated that body functional reserves were mobilized which could eventually lead to adaptation failure.

Research on $\beta$-adrenoreactivity of erythrocytes membranes in female migrants was performed depending on adaptation process stage as per functional changes index. When adaptation was satisfactory parameters of $\beta$ ARM were within physiological changes range and didn't depend on duration of staying; when there was adaptation mechanisms strain or adaptation was unsatisfactory, the most signifi- cant increase in $\beta$-ARM parameter was observed in Tadjiks females regardless of dura

tion of their staying on an adverse territory (figure).

When sympathoadrenal system becomes more active, protective cellular membranes desensitization occurs which leads to greater $\beta$-ARM parameters in blood. Increase in $\beta$ ARM value in all the examined women proved that their adrenoreactivity decreased at cellular and system levels which was the evidence of non-specific protection mechanisms aimed at eliminating destructive impacts exerted by increased catecholamine content under longterm psychoemotional stress. It proved changes in the processes of catecholamines synthesis, storage, and metabolism, as well as sensitivity (desensitization) of erythrocytes cellular membranes receptors. Such changes can be viewed as unfavorable predictive criterion of diseases risk with pathogenesis mostly related to sympathoadrenal system activity. 


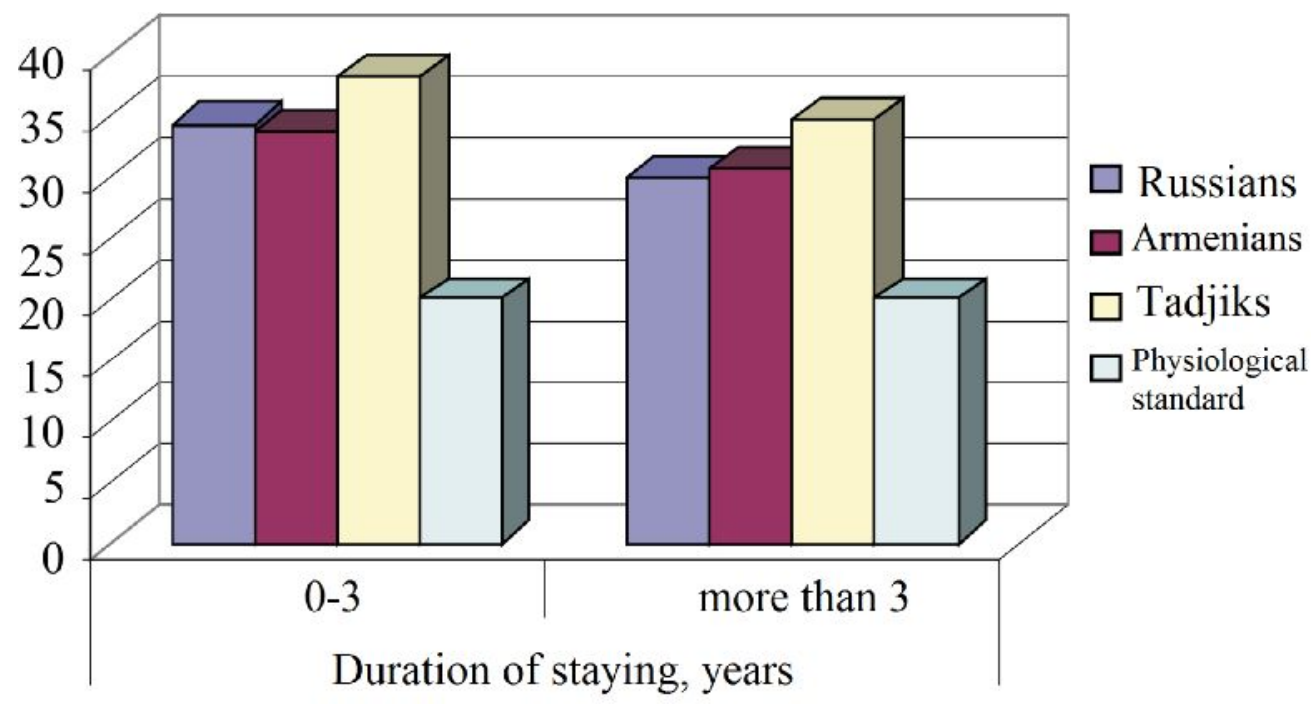

Figure. Parameters of $\beta$-ARM in blood of women from various occupational groups with unsatisfactory adaptation

The obtained data correlate directly to changes in physiological parameters of adaptation processes strain in the examined women. When adaptation protection mechanisms are mobilized under intense impacts exerted by environment as well as under psychoemotional pressure related to a move to a new place of residence and peculiarities of a body functioning in this new place, protective and modulating functions of desensitization can prevail and become apparent through more explicit strain in physiological parameters on the system level. It will undoubtedly lead to decompensated hyperadrenergic states and high risks of cardiovascular pathology and other diseases.

Health disorders prevention aimed at preserving migrants labor potential requires developing medical and social support activities allowing for functional rearrangement of a body regulatory mechanisms. Primary prevention includes physical training, healthimproving activities, autogenic training, elimination of adverse social and occupational risk factors; secondary prevention comprises preliminary and periodical medical examinations.

Conclusions. The results of examining peculiarities of female migrants' functional state during adaptation to impacts exerted by neuro-emotional, social and psychological factors, physical (muscular) loads varying in their intensity and duration revealed that adaptation strain syndrome as per physiological parameters became apparent through increase in index of functional changes in circulatory system, changes in heart rate variability as per regulatory systems activity parameter, PARS.

We determined peculiarities of adaptation process in female migrants: if they stayed on the examined territory for less than 3 years, the greatest specific weight of migrants with unsatisfactory adaptation was detected among Russians (36.04\%); and with adaptation mechanisms strain, among Tadjiks $(62.08 \%)$. But if they stayed for longer than 3 years, unsatisfactory adaptation parameters grew by $12.4 \%$ among Tadjiks which indicated that body functional reserves were mobilized and it could lead to adaptation failure.

Parameters of $\beta$-adrenoreactivity of erythrocytes membranes which were detected at satisfactory adaptation were within physiological changes range regardless of duration of staying. When adaptation mechanisms were strained or adaptation was unsatisfactory, the most significant increase in $\beta$-ARM parameter was observed in Tadjiks females regardless of how long they stayed on an ecologically adverse territory.

To preserve migrants health and labor potential, it is essential to organize medical and 
social support for coming workers. primary health disorders prevention should include includes physical training, health-improving activities, autogenic training, elimination of adverse social and occupational risk factors.
Secondary prevention techniques are systematic medical control over migrants' health including preliminary and periodical medical examinations.

\section{References}

1. Badal'yants S.V. Sotsial'naya integratsiya migrantov v rossiiskoe obshchestvo [Migrants' social integration into Russian society]. Sotsial'no-ekonomicheskie aspekty razvitiya sovremennogo obshchestva: sbornik materialov Mezhdunarodnoi nauchno-prakticheskoi konferentsii [Social and economic aspects of contemporary society development: collected materials of the International theoretical and practical conference]. Tambov, 2012 (in Russian).

2. Badal'yants S.V. Trudoustroistvo migrantov $\mathrm{v}$ kontekste upravleniya migratsionnoi politikoi $\mathrm{v}$ sovremennoi Rossii [Employment of migrant workers in the context of migration policy management]. Gosudarstvennoe i munitsipal'noe upravlenie. Uchenye zapiski SKAGS. - 2012. - № 4. - pp. 183-188 (in Russian).

3. Balabanov S.S., Saralieva Z.Kh. Seksual'nye domogatel'stva na rabote v Rossii [Sexual advances on work in Russia]. Vestnik nizhegorodskogo universiteta im. N.I. Lobachevskogo. Seriya: sotsial'nye nauki, 2010, vol. 17, no. 1, pp. 7-12 (in Russian).

4. Baevskii P.M., Ivanov G.G., Chireikin L.V., Gavrilushkin A.P., [et al.] V pomoshch' prakticheskomu vrachu. Analiz variabel'nosti serdechnogo ritma pri ispol'zovanii razlichny elektrokardiograficheskikh sistem: metodicheskie rekomendatsii [To help a practitioner. Heart rate variability analysis when applying various electrocardiographic systems]. Vestnik aritmologii, 2001, no. 24, pp. 65-87 (in Russian).

5. Dement'eva S.V. Osobennosti adaptatsii migrantov iz zarubezhnykh stran v gorodakh Rossii po dannym sotsiologicheskikh issledovanii [Adaptation peculiarities of migrants from foreign countries in Russian cities as per sociological research data]. Izvestiya Tomskogo politekhnicheskogo universiteta. Inzhiniring georesursov, 2005, vol. 308, no. 5, pp. 195-199 (in Russian).

6. Dzhafarli N. Sovershenstvovanie mekhanizma sotsial'noi adaptatsii migrantov v Rossii [Developing a social adaptation mechanisms of migrants in Russia]. Sovremennaya psikhologiya: teoriya $i$ praktika: Materialy KhVI mezhdunarodnoi nauchno-prakticheskoi konferentsii [Contemporary psychology: theory and practice: Materials of the XVI international theoretical and practical conference]. Moscow, Institut strategicheskikh issledovanii Publ., 2015, pp. 101-105 (in Russian).

7. Tyuryukanova E.V., Zaionchkovskaya Zh.A., Karachurina L.B., Mkrtchyan N.V., Poletaev D.V., Florinskaya Yu.F. Zhenshchiny-migranty iz stran SNG v Rossii [Female migrants from the CIS countries in Russia]. In: E.V.Tyuryukanova ed. Moscow, MAKS Press, 2011, 120 p. (in Russian).

8. Profilaktika stressovogo sostoyaniya rabotnikov pri razlichnykh vidakh professional'noi deyatel'nosti: Metodicheskie rekomendatsii MR 2.2.9.2311-07 [Prevention of stress in workers with various occupations: Methodical Guidelines MP 2.2.9.2311-07]. Moscow, Gosudarstvennym uchrezhdeniem Nauchno-issledovatel'skii institut meditsiny truda RAMN, 2007, 26 p.

9. O sostoyanii migratsionnoi politiki v Rossiiskoi Federatsii i putyakh ee sovershenstvovaniya: Postanovlenie ot 28.03.2012 № 62-SF [On migration policy status in the Russian Federation and ways of its improvement: Resolution dated March, 28, 2012 No. 62-SF]. Moscow, 2012. Available at: http://council.gov.ru/activity/documents/9295/ (28.11.2016) (in Russian).

10. Optimizatsiya funktsional'nogo sostoyaniya organizma v fizkul'tur-no-ozdorovitel'nom tsentre promyshlennogo predpriyatiya: Metodicheskie rekomendatsii [Optimization of the body functional state in a physical training and health center of an industrial enterprise: Methodical Guidelines]. In: R.M. Baevskii ed. Moscow, 1988, 23 p. (in Russian).

11. Poletaev D.V. Adaptatsiya domashnikh rabotnikov-migrantov v Rossii [Adaptation of domestic migrant workers in Russia]. Tezisy dokladov mezhdunarodnoi nauchnoi konferentsii "Chelovek $v$ menyayushchemsya mire. Problemy identichnosti $i$ sotsial'noi adaptatsii $v$ istorii i sovremennosti: metodologiya, metodika i praktiki issledovaniya» [Theses of the reports, International scientific confer- 
ence «A man in the changing world. Historical and contemporary issues of identity and social adaptation: methodology, methods and research practices»]. Tomsk, Izd-vo Tomskogo universiteta, 2014, pp. 95-96 (in Russian).

12. Rukovodstvo po gigienicheskoi otsenke faktorov rabochei sredy i trudovogo protsessa. Kriterii i klassifikatsiya uslovii truda R 2.2.20006-05 [Guide on hygienic assessment of working environment factors and working process factors. Labor conditions criteria and classification P 2.2.20006-05]. Moscow, Federal'nyi tsentr gigieny i epidemiologii Rospotrebnadzora, Publ., 2005, 142 p. (in Russian).

13. Al-Roubaiy N.S., Owen-Pugh V., Wheeler S. The experience of exile-related stress among Iraqi refugee men in Sweden and its implications for counselling and psychotherapy: A qualitative study. Counselling Psychology Review, 2013, vol. 28, no 2, pp. 53-67.

14. Barry D.T. Measuring acculturation among male Arab immigrants in the United States: An exploratory Study. Journal of Immigrant Health, 2005, vol. 7, no. 3, pp. 179-184.

15. Burke S., Chaney E., Bethel J.W. Stress, Depression and Coping among Latino Migrant and Seasonal Farmworkers. International Journal of Environmental Research and Public Health, 2013, vol. 10, no. 5, pp. $1815-1830$.

16. Castonguay L.G., Newman M.G., Borkovec T.D., Holtforth M.G., Maramba G.G. Cognitivebehavioral assimilative integration: Handbook of psychotherapy integration (2nd edn,); J.C. Norcross, M.R. Goldfried eds. New York, Oxford University Press Publ., 2005, pp. 241-260.

17. Colic-Peisker V., Walker I. Human capital, acculturation and social identity: Bosnian refugees in Australia. Journal of Community and Applied Social Psychology, 2003, vol. 13, pp. 337-360.

18. Hansen E., Donohoe M. Health issues of migrant and seasonal farmworkers. J. Health Care Poor Underserved, 2003, vol. 14, pp. 153-164.

Izmerov N.F., Izmerova N.I., Bukhtiyarov I.V., Khodzhiev M. Peculiarities of adaptation reactions in female migrants and health disorders risks occuring after different periods of staying on Moscow region territory. Health Risk Analysis, 2017, no. 2, pp. 109-116. DOI: 10.21668/health.risk/2017.2.13.eng

Received: 22.12.2016

Accepted: 20.02 .2017

Published: 30.06 .2017 


\title{
EXPERIMENTAL MODELS AND INSTRUMENTAL SURVEYS FOR RISK ASSESSMENT IN HYGIENE AND EPIDEMIOLOGY
}

UDC 637.2.07: 543.423.1

DOI: $10.21668 /$ health.risk/2017.2.14.eng

\section{WORKING OUT PROCEDURES FOR ANALYZING TOXIC ELEMENTS CONTENT \\ IN OIL PRODUCTS AND OIL RAW MATERIALS USING ATOMIC-EMISSION \\ SPECTROMETRY WITH INDUCTIVE-BOUND PLASMA TO ASSESS \\ PRODUCTS SAFETY}

\author{
L.S. Ivashkevich, T.V. Kovshova, O.N. Vashkova, Yu.N. Velentei \\ Scientific-practical Hygiene Center, 8 Akademicheskaya Str., Minsk, 220012, Republic of Belarus
}

\begin{abstract}
Our goal was to work out a procedure aimed at determining low concentrations of toxic elements in oil products using atomic-emission spectrometry to assess products safety.

We performed a comparative examination of various mineralization techniques, studied extraction conditions impacts, as well as autoclave and microwave mineralization impacts on the results of toxic elements determination in oil raw materials and oil products. We detected that complete mineralization enabled achieving the least results inaccuracy in comparison with acid extraction.

We developed parameters for atomic-emission analysis of determining $\mathrm{Fe}, \mathrm{Cu}, \mathrm{Ni}, \mathrm{Pb}$, and $\mathrm{Cd}$, in oil raw materials and oil products. We defined a wave length for each element and background correction; we also determined a device parameters (generator power, sample feeding speed, spraying speed), chose a cleft width and an analysis regime for data calculation.

Basing on the conducted research we created a high-precision procedure for determining low concentrations of such toxic elements, as $\mathrm{Pb}, \mathrm{Cd}, \mathrm{As}, \mathrm{Hg}, \mathrm{Cu}, \mathrm{Fe}$, and $\mathrm{Ni}$, with atomic-emission spectrometry technique. Standard deviation in the procedure repeatability amounts to 1.4-4.3\%. Standard deviation in the procedure reproducibility amounts to 10.1-11.8\%. maximum expanded uncertainty in measuring concentrations of $\mathrm{Cd}$, Pb, and $\mathrm{As}$, amounts to $30.6 \%$; $\mathrm{Hg}, 23 \%$; $\mathrm{Cu}, \mathrm{Fe}$, ands $\mathrm{Ni}, 21 \%$; $\mathrm{Pb}, 33 \%$.

Application of the created procedure will help to enhance control over quality and safety of food products and to lower alimentary morbidity.

Key words: toxic elements, atomic-emission spectrometry, oil raw materials, oil products, sample preparation, precision, food products safety.
\end{abstract}

Emissions from industrial enterprises and products. Toxic elements can also get into city transport contaminate the environment food products during production processes or and as a result toxic elements penetrate food if storage conditions are unsafe. When they

(C) Ivashkevich L.S., Kovshova T.V., Vashkova O.N., Velentei Yu.N., 2017

Liudmila St. Ivashkevich - Candidate of Technical Sciences, Head of chromatographic research laboratory; analysis of food chemical structure, spectrometer research (e-mail: Chromatographic@ @rspch.by; tel.: +375 17 28408-67).

Tatiana V. Kovshova - scientific officer at chromatographic research laboratory; analysis of food chemical structure (e-mail: Chromatographic@ rspch.by; tel.: +375 17 284-08-67).

Olga N. Vashkova - scientific officer at chromatographic research laboratory; analysis of food chemical structure (e-mail: Chromatographic@ rspch.by; tel.: +375 17 284-08-67).

Julia N. Velentei - junior scientific officer at spectrometer research laboratory, analysis of food chemical structure (e-mail: Chromatographic@ rspch.by, tel.: +375 17 284-08-67). 
enter a human body in excessive quantities it exerts negative impacts on the immune system; it can also cause substantial metabolic and functional disorders.

According to the Customs Union's Technical Regulations No. 021/2011 "On food products safety", four most widely spread and most dangerous toxicants, namely $\mathrm{Pb}, \mathrm{As}, \mathrm{Cd}$, and $\mathrm{Hg}$, are determined in all kinds of food raw materials and food products, including oil and fat ones. Apart from these four elements, $\mathrm{Cu}$ and $\mathrm{Fe}$ contents in vegetable oils, spreads, and rendered animal fats, are to conform to fixed standards as these elements influence oxidative processes activation. Ni contents are standardized in products which are the result of vegetable oil and animal fats processing (margarines, cooking fats, and mayonnaise) as $\mathrm{Ni}$ is a part of a catalyst used in products hydrogenation.

Food safety assessment includes control over toxic elements contents. Occurrence of such elements as $\mathrm{Pb}, \mathrm{As}, \mathrm{Cd}, \mathrm{Hg}, \mathrm{Fe}$, and $\mathrm{Cu}$, in oil products and oil raw materials is always analyzed; these elements can get into finished products either from raw materials or during production processes. Colorimetric, polarographic, or spectrometric techniques are used to perform such analysis $[1,6,7]$.

Atomic-emission spectrometry has a number of advantages over other techniques as it has low detection limits, and calibrating graphs linearity within a wide range of concentrations, and it allows to simultaneously determine a great number of elements.

Samples preparation has a great influence on the validity of the obtained results. Techniques applied in oil products samples preparation can be divided into two groups: acid extraction and complete mineralization. Nowadays there are several regulations which fix standards for oil products analysis and which envisage complete mineralization of samples; they are ISO 8294: 1994, ISO 15774: 2000, ISO 12193: 2004, ISO 10540-2: 2003. And there is a standard which fixes acid extraction, namely State Standard 26929-94. Literature sources [8, 11-14] state that results of mineral elements content examination in food products differ depending on a sample preparation technique. This difference is determined both by a chemical element essence, and its quantitative contents in food products.

Our research goal was to create a procedure for determining low concentrations of toxic elements in oil products using atomicemission spectrometry with inductively bound plasma to assess food products safety.

To achieve the stated goal, we solved a number of tasks; we worked out atomicemission analysis parameters and created samples preparation conditions for toxic elements analysis.

Data and methods. Our research objects were samples of refined and unrefined sunflower-seed oil, margarine, mayonnaise, sunflower seeds, poppy seeds, and fish oil.

Food products samples which were used in comparative examination of various mineralization techniques didn't contain any additives.

Native oil raw materials and oil products, and also products with known introduced toxic elements content were used as examination samples for metrological research. Toxic elements were introduced in quantities corresponding to their maximum permissible concentrations in food products. CONOSTAN oil standards (the USA) with the known toxic elements contents were used for sunflower-seed oil; standard $\mathrm{Pb}, \mathrm{Cd}, \mathrm{As}, \mathrm{Hg}, \mathrm{Cu}, \mathrm{Ni}$, and $\mathrm{Fe}$ solutions were used for other samples.

We used concentrated nitric acid (67\%, «for trace analysis» class, Fluka), hydrogen peroxide (36\%, puriss.), hydrochloric acid (36\%, puriss.), deionized water, which was received with the use of Direct-Q3 water deionizer (Millipore Corporation, the USA), and standard samples of $\mathrm{Pb}, \mathrm{Cd}, \mathrm{As}, \mathrm{Hg}, \mathrm{Cu}, \mathrm{Ni}$, and $\mathrm{Fe}$ solutions in our work.

Acid extraction techniques and complete mineralization techniques were applied in samples preparation.

We applied Horiba Jobin Yvon atomicemission spectrometer (Japan-France) with radial vision of argon plasma and 1 meter focal distance to determine elements content in mineralized samples. 
Results and discussion. Oil products mineralization techniques can be divided into two groups, namely acid extraction and complete mineralization; the latter means samples decomposition in mineral acids when analytical autoclaves are applied under thermal treatment or microwave radiation.

Extraction samples preparation has an advantage as it allows to obtained mineralized samples with high analyte content taking a substantial sample weight into account; it is also not necessary to use specialized equipment for mineralization.

We changed extraction time and solid and liquid phase ratio to study influence exerted by acid extraction conditions on the analysis results. Extraction was performed in a heatproof flask containing a sample, boiling centers and hydrochloric acid solution diluted 1:1 in volume. The flask content was boiled for 45 or 90 minutes. We applied the following ratios of a sample and acid-extractive mixture: $20 \mathrm{~g}$ and $40 \mathrm{ml}(1: 2) ; 8 \mathrm{~g}$ and $40 \mathrm{ml}$ (1:5); $4 \mathrm{~g}$ and $40 \mathrm{ml}$ (1:10).

As we can see in Figure 1, decrease in a ratio of a sample to an extracting agent volume leads to increase in extracted elements quantity. It becomes most apparent when $\mathrm{Cu}$ is extracted. Extracted $\mathrm{Cu}$ quantity varies 1.5-2.6 times depending on an examined sample and "sample - extracting agent" ratio. Fe quantity varies not so greatly, 1.1-1.5 times.

Increase in extraction time from 45 to 90 minutes also results in growing quantity of an element extracted out of a sample. $\mathrm{Cu}$ quantity grows by $10-40 \%$; Fe quantity, by about $10 \%$.

So, the obtained data allow us to conclude that decrease in a ratio of a sample weight to a sample volume and increase in extraction time leads to growth in the quantity of elements extracted out of a sample. We should note that decrease in a ratio of a sample weight to an extracting agent volume also results in greater errors in measurement. Maximum error for ratio 1:2 amounts to $3 \%$ for $\mathrm{Cu}$ and $8 \%$ for $\mathrm{Fe}$; it is equal to 10 and $25 \%$ correspondingly when ratio is 1:10.

The performed examinations enables determining the most suitable conditions of extraction sample preparation which allow to

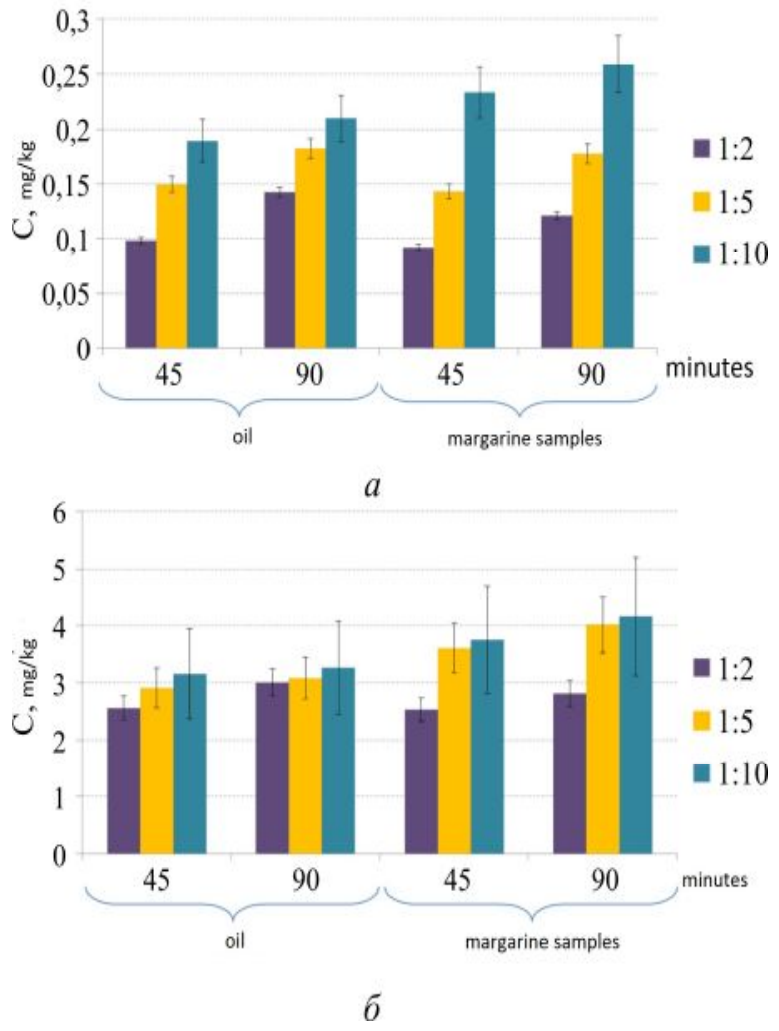

Figure 1. Influence exerted by acid extraction conditions

on the results of determining $\mathrm{Cu}(a)$ and $\mathrm{Fe}(\sigma)$ in oil and margarine samples

extract maximum quantity of elements; these conditions include sample weight being equal to $4 \mathrm{~g}$ and acid extraction ratio being 1:10; optimal extraction time is 1.5 hours.

Acid extraction can be applied only when treating vegetable oil, butter, food fats, and margarine. Besides, this sample preparation technique is not suitable for determining highly volatile elements, notably, $\mathrm{Hg}$.

Complete decomposition performed in closed vessels allows to avoid possible losses of highly volatile elements.

When performing complete mineralization, we put a sample weighing 0.5-2 g into a fluoroplastic cup, embedded it with an oxidative mixture made of concentrated nitric acid and concentrated hydrogen peroxide, and then, after a preliminary exposure, we performed mineralization heating the mixture or treating it with microwave radiation. We obtained the control solution by performing mineralization without a sample. To examine conditions of 
autoclave sample preparation we applied two mineralization regimes with different time and temperature. The first regime which was a longer one was accomplished in three stages with a gradient reaction mixture temperature rise during 30 minutes and heating under a certain temperature: $160{ }^{\circ} \mathrm{C}$ for 1 hour, $180^{\circ} \mathrm{C}$ for 1 hour, $200{ }^{\circ} \mathrm{C}$ for 2 hours. The second regime had two stages: $160{ }^{\circ} \mathrm{C}$ for 1 hour, $180{ }^{\circ} \mathrm{C}$ for 2 hours. The research revealed that mineralization regime had no influence on the results of mineral elements $(\mathrm{Cu}$ and $\mathrm{Fe})$ determination in sunflower-seed oil. Difference between the results amounted to only $1-3 \%$.

We performed microwave mineralization of oil products samples applying a multi-stage program under controlled growing pressure and temperature conditions for each product type. Microwave sample preparation examination enabled determining the most efficient microwave mineralization regime for all oil products samples.

We compared various mineralization techniques, including autoclave and microwave one, as well as acid extraction. When acid extraction was performed, we applied conditions which allowed to obtain the maximum quantities of extracted elements. We applied the following program for microwave decomposition: control over the process as per pressure, control pressure value $P$ was equal to $160 \mathrm{psi}(1,103 \mathrm{MPa})$, decomposition time was 25 minutes. Autoclave mineralization process included two stages: $160{ }^{\circ} \mathrm{C}$ for 1 hour, $180{ }^{\circ} \mathrm{C}$ for 2 hours.
Table 1 summarizes the comparative characteristics of influence exerted by various mineralization techniques on the results of determining $\mathrm{Cu}$ and $\mathrm{Fe}$ in oil products. Data comparison reveals that the created mineralization parameters allowed to obtain identical information on $\mathrm{Fe}$ quantity both at complete and incomplete samples mineralization. $\mathrm{Cu}$ content determined in the samples after extraction varies from 62 to $87 \%$ of the content obtained after complete mineralization. It can be related to low $\mathrm{Cu}$ concentrations in oil products, much lower than Fe concentrations; or it can be related to peculiarities which extraction of this element has.

In relation to that we considered a possibility to apply autoclave sample preparation or preparation in a microwave mineralizer to perform atomic-emission analysis of toxic elements.

The greatest sample volume was used in complete mineralization and it led to relatively low concentrations of an analyzed element in a mineralized solution. This problem can be solved either via mineralizing agent concentrating, or via application of analysis techniques and devices with low detection limits.

Choice of a wave length, sample feeding speed, spraying speed, data acquisition regime, as well as application of an ultra-sound sprayer instead of a pneumatic one allow to obtain a considerable growth in elements detection sensitivity.

Table 1

$\mathrm{Cu}$ and $\mathrm{Fe}$ content in oil products after different sample preparation techniques, $\mathrm{mg} / \mathrm{kg}$

\begin{tabular}{|l|c|c|c|c|}
\hline \multirow{2}{*}{ Sample } & \multirow{2}{*}{ Element } & \multicolumn{3}{|c|}{ Mineralization regime } \\
\cline { 3 - 5 } & & autoclave & microwave & extraction \\
\hline \multirow{2}{*}{ Sunflower-seed oil } & $\mathrm{Cu}$ & $0,26 \pm 0,04$ & $0,19 \pm 0,01$ & $0,16 \pm 0,02$ \\
\cline { 2 - 5 } & $\mathrm{Fe}$ & $3,37 \pm 0,05$ & $2,29 \pm 0,16$ & $3,26 \pm 0,39$ \\
\hline \multirow{2}{*}{ Margarine } & $\mathrm{Cu}$ & $0,30 \pm 0,02$ & $0,41 \pm 0,01$ & $0,26 \pm 0,04$ \\
\cline { 2 - 5 } & $\mathrm{Fe}$ & $4,10 \pm 0,56$ & $4,40 \pm 0,5$ & $4,16 \pm 0,37$ \\
\hline \multirow{2}{*}{ Mayonnaise } & $\mathrm{Cu}$ & $0,26 \pm 0,03$ & $0,38 \pm 0,04$ & - \\
\cline { 2 - 5 } & $\mathrm{Fe}$ & $2,83 \pm 0,05$ & $3,56 \pm 0,21$ & - \\
\hline \multirow{2}{*}{ Sunflower seeds } & $\mathrm{Cu}$ & $21,86 \pm 0,09$ & $21,22 \pm 0,55$ & - \\
\cline { 2 - 5 } & $\mathrm{Fe}$ & $50,45 \pm 0,19$ & $52,80 \pm 1,98$ & - \\
\hline
\end{tabular}


To obtain lower detection limits of an atomic-emission spectrometer, we used the following device parameters:

- generator capacity was $1000-1100 \mathrm{Wt}$;

- plasma gas flow rate was $12 \mathrm{l} / \mathrm{min}$;

- gas flow rate in a sheath was $0.21 / \mathrm{min}$;

- assist gas rate was $01 / \mathrm{min}$;

- sprayer was $0.8 \mathrm{l} / \mathrm{min}$ at $2.8 \mathrm{bar}$;

- sample feeding speed, $1 / \mathrm{min}$, was 0.84 1/min;

- photomultiplier amplification was 100 .

Measurements were performed at the following wave lengths, $\mathrm{nm}: \mathrm{Pb}-220.353$; As 193,.695; $\mathrm{Cd}-228.802 ; \mathrm{Hg}-194.163 ; \mathrm{Cu}-$ 324.754; $\mathrm{Fe}-259.940 ; \mathrm{Ni}-221.647$.

As a rule, detection limits for mineralized samples are much higher than for water solutions which is related to a matrix influence exerted by a mineralizing agent $[4,5]$. Basic noises occur in plasma [9]. Changes occurring in a spraying system or a sample feeding system also contribute considerably into matrix noises. When acid concentrations or dissolved substance contents vary it leads to changes in spraying efficiency and, consequently, to changes in sensitivity. It is noted in the paper [8] that perchloric acid or hydrochloric acid are the best analytical media for atomicemission measuring. However, food products mineralization or biological substrates mineralization is usually performed with nitric acid with its final concentration in a mineralized solution being equal to $25-30 \%$. It is also stated in the paper, that growth in nitric acid concentration to $30 \%$ results in $30 \%$ decrease in $\mathrm{Mg}$ and $\mathrm{Al}$ emission signal intensity in comparison with 5\%-concentrated nitric acid.

We determined detection limits for each examined elements via its tenfold measuring in the control solution.

A conventional way to introduce a solution into inductively bound plasma is to apply a pneumatic sprayer. An ultra-sound sprayer allows to obtain significantly lower detection limits for a spectrometer. A liquid sample is pumped into a piezoelectric detector where it is transformed into a dense thick spray. Gas flow in a sprayer takes this spray through a heating tube where evaporation takes place and the liquid is further condensed with a thermoelectric cooler and is taken out via drainage. As a result, a dry highly concentrated spray is in a sprayer and it is sprayed in plasma. It allows to get 5-10 times better elements detection limits.

Detection limits for $\mathrm{Pb}$ and $\mathrm{As}$ were obtained with the use of an ultrasound sprayer; for $\mathrm{Cu}, \mathrm{Fe}, \mathrm{Ni}$, and $\mathrm{Cd}$, with a pneumatic sprayer.

Table 2 contains data on an approximate content of $\mathrm{Pb}, \mathrm{As}, \mathrm{Cu}, \mathrm{Cd}, \mathrm{Fe}, \mathrm{Ni}$, and $\mathrm{Hg}$, in solutions after complete mineralization of samples containing toxic elements at the level set forth in the regulations, at a device detection level, and the obtained elements detection limits.

As we can see from Table 2, detection limits obtained under real life conditions differ from those declared by a manufacturer. Spectral and matrix influences which occurred when samples with a complicated structure were analyzed led to substantial rise of determined contents bottom boundary and made it more difficult to determine elements correctly in complex biological samples. Difference for $\mathrm{Cu}$ amounted to 2.45; for As and $\mathrm{Cd}$, to 4.6-4.8. The greatest discrepancy between the measured detection limit and a declared one was revealed for $\mathrm{Pb}$, and it makes it obvious that a device parameters need to be adjusted in case one performs separate measuring of this element.

If we compare device detection limits with a pneumatic sprayer for $\mathrm{Hg}$ and permissible $\mathrm{Hg}$ content in a solution (Table 2), we can see that to it is necessary to apply hydride generation to detect this element.

The technique is based on $\mathrm{Hg}$ recovery with $\mathrm{Na}$ borohydride as per reaction scheme

$$
\mathrm{Hg}^{2+}+\mathrm{BH}_{4}^{-}+\mathrm{H}^{+} \rightarrow \mathrm{B}_{2} \mathrm{H}_{6}+\mathrm{H}_{2}+\mathrm{Hg} \text {. }
$$

$\mathrm{B}_{2} \mathrm{H}_{6}$ is then hydrolyzed into boric acid.

Research on influence exerted by different acids on efficiency of determining hydrideforming elements revealed that $2 \mathrm{M}$ hydrochloric acid solution was the most suitable medium for $\mathrm{Hg}$ detecting $[2,3,15]$.

When autoclave mineralization is performed, an analyte is in nitric acid. Its further transformation into a muriate solution is quite complicated as elimination of nitric acid remains under thermal treatment can cause $\mathrm{Hg}$ losses. In relation to that we studied a possibility to detect $\mathrm{Hg}$ in nitric acid solutions. 
Table 2

Toxic elements content in a mineralized solution after acid extraction and detection limits

\begin{tabular}{|c|c|c|c|c|c|}
\hline \multirow{3}{*}{ Element } & \multirow{3}{*}{$\begin{array}{c}\text { Content in a mineralized } \\
\text { solution } *, \mu \mathrm{g} / \mathrm{dm}^{3}\end{array}$} & \multicolumn{3}{|c|}{ Device detection limit, $\mu \mathrm{g} / \mathrm{dm}^{3}$} & \multirow{3}{*}{$\begin{array}{l}\text { Detection limit, } \\
\qquad \mu \mathrm{g} / \mathrm{dm}^{3}\end{array}$} \\
\hline & & \multicolumn{2}{|c|}{ Sprayer } & \multirow{2}{*}{$\begin{array}{l}\text { Hydride } \\
\text { add-on de- } \\
\text { vice }\end{array}$} & \\
\hline & & pneumatic & ultrasound & & \\
\hline $\mathrm{Pb}$ & $4-40$ & 1,5 & 0,2 & - & 1,91 \\
\hline As & $4-40$ & 1,5 & 0,2 & 0,2 & 0,92 \\
\hline $\mathrm{Cu}$ & $4-16$ & 0,2 & 0,05 & - & 0,49 \\
\hline $\mathrm{Cd}$ & $1-20$ & 0,15 & 0,02 & - & 0,72 \\
\hline $\mathrm{Fe}$ & $60-200$ & 0,2 & 0,05 & - & 5,11 \\
\hline $\mathrm{Ni}$ & 28 & 0,3 & 0,06 & - & 1,78 \\
\hline $\mathrm{Hg}$ & $0,1-12$ & 0,4 & - & 0,03 & - \\
\hline
\end{tabular}

Note: * sample weight is equal to $1 \mathrm{~g}$ and a mineralizing agent volume is equal to $25 \mathrm{ml}$.

We used $0.6 \%$ borohydride solution in $0.05 \mathrm{M}$ $\mathrm{NaOH}$ as a borohydride solution.

Figure 2 shows dependence between energy emission (signal intensity) and $\mathrm{Hg}$ content in standard samples in $3 \mathrm{H} \mathrm{HCl}$ and $3 \mathrm{H}$ $\mathrm{HNO}_{3}$ medium. As we can see from Figure 2, $\mathrm{Hg}$ emission energy value in nitric acid solution is insignificantly higher than emission of this element in hydrochloric acid solution and it proves that it is quite possible to use nitric acid solutions directly for introducing into a hydride add-on device.

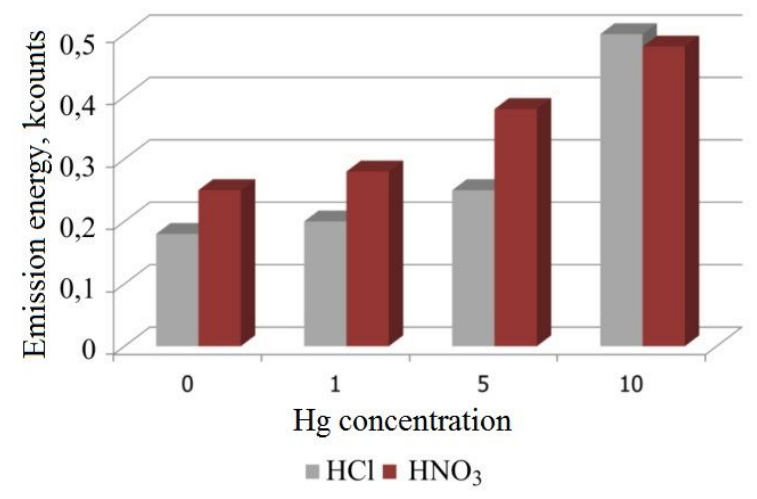

Figure 2. Emission energy dependence on $\mathrm{Hg}$ content in standard samples

in $3 \mathrm{H} \mathrm{HCl}$ and $3 \mathrm{H} \mathrm{HNO}_{3}$ medium

Precision and correctness parameters were determined during metrological certification of the technique. Precision parameters (repeata- bility and laboratory reproducibility) were determined in conformity with STB ISO 5725-2, cl. 7. To assess correctness parameter, we used the results of checking significance of discrepancy from recovery rate unit (STB ISO 5725-4, cl. 4). Recovery rate for toxic elements as per this technique was studied in laboratories under repeatability conditions via analyzing samples with the known toxic elements admixture.

Metrologic calculations revealed that standard deviation in the repeatability for the examined toxic elements with the use of the created conditions amounts to $1-8 \%$; standard deviation in the reproducibility for these elements lies within 2-22\% range.

We detected dependence of maximum extended uncertainty $(U)$ on concentrations of toxic elements in oil raw materials and oil products.

Maximum extended uncertainty within the range of the measured $\mathrm{Pb}, \mathrm{Cd}, \mathrm{Hg}, \mathrm{Cu}, \mathrm{Fe}$, and $\mathrm{Ni}$ concentrations in oil raw materials and oil products is within $4-15 \%$; it amounts to $33 \%$ in case of $\mathrm{Pb}$.

Conclusions. So, basing on the results of the conducted research we worked out a high precision technique for determining low concentrations of toxic elements with the use of atomicemission spectrometry. 


\section{References}

1. Amelin V.G., Lavrukhina O.I. Obespechenie bezopasnosti pishchevykh produktov sredstvami khimicheskogo analiza [Providing food products safety by chemical analysis techniques]. Zhurnal analiticheskoi khimii, 2017, no. 1, pp. 3-49 (in Russian).

2. Gladyshev V.P. Analiticheskaya khimiya rtuti [Analytical chemistry of copper]. Moscow, Nauka Publ., 1974, 528 p. (in Russian).

3. Lakota V.N., Makarevich V.I., Arkhutik S.S. Opredelenie mysh'yaka, rtuti i selena metodom atomnoemissionnoi spektrometrii s induktivno-svyazannoi plazmoi [Determining arsenic, mercury, and selenium via atomic emission spectrometry with inductively bound plasma]. Zhurnal analiticheskoi khimii, 1999, vol. 54, no. 3, pp. 285-287 (in Russian).

4. Osipov K.B., Seregina I.F., Bol'shov M.A. Ustranenie matrichnykh nespektral'nykh pomekh pri elementnom analize biologicheskikh zhidkostei na kvadrupol'nom mass-spektrometre s induktivnosvyazannoi plazmoi [Elimination of matrix non-spectral interferences in elemental analysis of biological fluids using inductively coupled plasma quadrupole mass spectrometer]. Analitika i kontrol', 2014, vol. 18, no. 2, pp. 150-163 (in Russian).

5. Tsygankova A.R., Makashova G.V., Shelpakova I.R. Zavisimost' intensivnosti spektral'nykh linii elementov ot moshchnosti ISP-plazmy i raskhoda argona [Dependence of elements' spectral lines intensity on inductively bound plasma capacity and argon flow]. Metody $i o b^{\prime \prime} e k t y$ khimicheskogo analiza, 2012, vol. 7, no. 3, pp. 138-142 (in Russian).

6. Acar O. Evaluation of cadmium, lead, copper, iron and zinc in Turkish dietary vegetable oils and olives using electrothermal and flame atomic absorption spectrometry // Grasas y Aceites. 2012. vol 63, no. 4, pp. 383-393.

7. Taylor A., [et.al.]. Atomic spectrometry update: review of advances in the analysis of clinical and biological materials, foods and beverages. JAAS: Journal of Analytical Atomic Spectrometry, 2016, vol 31, no. 3, pp. 554-596.

8. Chan G.C-Y., Hieftje G.M. Fundamental characteristics of plasma-related matrix-effect crossover points in inductively coupled plasma-atomic emission spertrometry. J. Anal. At. Spectrom, 2009, vol. 24, pp. 439-450.

9. Todolí J.L., [et.al.]. Elemental matrix effects in ICP-AES. J. Anal. At. Spectrom. 2002, vol. 17, pp. $142-169$.

10. Fuh Chwan-bor, Lin Huei-Ia, Tsai Hweiyan. Determination of Lead, Cadmium, Chromium, and Arsenic in 13 Herbs of Tocolysis Formulation Using Atomic Absorption Spectrometry. Journal of Food and Drug Analysis, 2003, vol. 11, no. 1, pp. 39-45.

11. García-Rey R.M., R. Quiles-Zafra, Luque de Castro M.D. New methods for acceleration of meat sample preparation prior to determination of the metal content by atomic absorption spectrometry. Anal. Bioanal. Chem, 2003, no. 377, pp. 316-321.

12. Ivanenko N.V. Biomonitoring of 20 trace elements in blood and urine of occupationally exposed works by sector field inductively coupled plasma mass spectrometry. Talanta, 2013, vol. 116, pp. 764-769.

13. Juranovic I., Breinhoelder P., Steffan I. Determination of trace elements in pumpkin seed oils and pumpkin seeds by ICP-AES. Anal. At. Spectrom, 2003, vol. 18, pp. 54-58.

14. Tasan M., Umit G., Demirci M. Effects of storage and industrial oilseed extraction methods on the quality and stability characteristics of crude sunflower oil. Grasas y aceites, 2011, vol. 62, no. 4, pp. 389-398.

15. Thompson P., Walton S.J. Simultaneous determination of trace Concentrations of Arsenic, Antimony, Bismuth, selenium and tellurium in aqueous solution by introduction of the gaseous hydrides into an inductively coupled plasma source for emission spectrometry. Analyst, 1978, vol. 103, pp. 568579 .

Ivashkevich L.S., Kovshova T.V., Vashkova O.N., Velentei Yu.N. Working out procedures for analyzing toxic elements content in oil products and oil raw materials using atomic-emission spectrometry with inductive-bound plasma to assess products safety. Health Risk Analysis, 2017, no. 2, pp. 117-124. DOI: 10.21668/health.risk/2017.2.14.eng 
Received: 03.03.2017

Accepted: 10.05.2017

Published: 30.06.2017 
UDC 546.3:577.121.7

DOI: $10.21668 /$ health.risk/2017.2.15.eng

\section{INFLUENCE EXERTED BY REDOX-ACTIVE METALS ON OXIDATIVE STRESS EVIDENCE IN AN EXPERIMENT}

\section{L.A. Chesnokova, I.V. Mikhailova, S.I. Krasikov, V.M. Boev}

Orenburg State Medical University, 6 Sovetskaya Str., Orenburg, 460000, Russian Federation

Our research goal was to study influence exerted by $\mathrm{Fe}^{2+}$ and $\mathrm{Cr}^{6+}$ cations on oxidative stress signs during an experiment on Wistar rats. We detected that when these metals were introduced into animals it caused free radical oxidation activation which became apparent through changes in chemiluminescense intensity in blood serum, in increased malonic dialdehyde and diene conjugants concentrations in blood serum and tissues (liver and pancreas), and in depression of antioxidant enzymes of superoxide dismutase and catalase erythrocytes. We showed that $\mathrm{Fe}^{2+}$ introduction with drinking water in a dose equal to maximum permissible concentration (MPC) could cause moderate activation of free radical oxidation as iron was a key element in active particles generation in biological media, including superoxide-anion-radical and most reactive hydroxyl radical. As we studied possible influence exerted by another redox-active metal, namely $\mathrm{Cr}^{6+}$, in concentration equal to $1 \mathrm{MPC}$ we also detected enhanced free radical processes in blood serum which became more intense as exposure duration grew. Luminescence sum representing total antioxidant blood serum activity was almost 2.5 times higher as per two experimental periods when Cr6+ was introduced in comparison with intact animals. Processes activation under chromium cations effects is determined by its direct influence on free-radical mechanisms. $\mathrm{Cr}^{6+}$ ions recover to $\mathrm{Cr}^{3+}$ in biological media; one-electron recovery process with intermediates forming at intermediate oxidation levels involves occurrence of active oxygen forms; it results in free radical processes enhancement.

Key words: rats, redox-active metals, free radical oxidation, malonic dialdehyde, maximum permissible concentration, biological medium, impact.

Relevance in studying negative effects on human health as a result of environment pollution with heavy metals is determined by the prevalence of these chemicals in atmospheric air, natural and drinking water, soil, food, and by various mechanisms of their influence on human body. Understanding the mechanisms of impact allows us to further assessing risks to human health, and taking preventive measures in order to minimize them. Literature shows the direct impact of eco-toxicants, including heavy metals, which have a pronounced redox-activity on human health $[1,2$,
11-13]. Metal-mediated generation of free radicals initiates various processes, including an increased lipid peroxidation (LPO). Lipid peroxides formed by the action of radicals, provided further exposure to such metals as chromium and iron, can form malonic dialdehyde (MDA), 4-hydroxynonenal and other toxic products $[3,4,7,20]$. Proceeding from above, it seems relevant to study the effect of iron and chromium cations on oxidative stress signs during an experiment in animals that the present research work was targeted on.

(C) Chesnokova L.A., Mikhailova I.V., Krasikov S.I., Boev V.M., 2017

Larisa A. Chesnokova - Candidate of Biological Sciences, Associate Professor at Chemistry and Pharmaceutical Chemistry Department (e-mail: chesnokovalarisa@mail.ru; tel.: +7(3532)77-65-64).

Irina V. Mikhailova - Doctor of Biological Sciences, Associate Professor at Chemistry and Pharmaceutical Chemistry Department (e-mail: michaylova74@yandex.ru; tel.: +7(3532)77-65-64).

Sergei I. Krasikov - Doctor of Medical Sciences, Professor, Head of Chemistry and Pharmaceutical Chemistry Department (e-mail: ks oren@mail.ru; tel.: +7(3532)77-65-64).

Viktor M. Boev - Doctor of Medical Sciences, Professor, Head of Common and Communal Hygiene Department (e-mail: kafedragigiena@ mail.ru; tel.: +7 (3532) 77-71-26). 
Materials and methods. Experiments were performed on 68 mature male Wistar rats weighing 250-300 g. Animals were divided into 3 groups and kept on a standard diet; The $1^{\text {st }}$ group $(n=24)$ served as reference, these animals unlimitedly consumed water from local artesian sources. Drinking water for experimental group rats $(n=26)$ during 45 days was added with $\mathrm{Fe}^{2+}$ in amount of 0.5 MPC. Animals of the other group $(n=32)$ received $\mathrm{Cr}^{6+}$ at $1 \mathrm{MPC}$ with drinking water during 45 and 90 days (SanPiN 2.1.4.1074-01 "Drinking water").

At the end of experiment, animals were decapitated under etheric Rausch anesthesia, in accordance with ethical norms and recommendations on humanizing treatment of laboratory animals described in "European Convention for the Protection of Vertebrate Animals used for Experimental and Other Scientific Purposes" (Strasbourg, 1985). Blood for separation into plasma and red blood cells was centrifuged at $2600 \mathrm{rpm}$ during 10 minutes. In erythrocyte lysates, we determined activity of superoxide dismutase (SOD) by adrenaline autooxidation rate into adrenochrome, and catalase activity using kinetic method by direct recording of hydrogen peroxide decomposition [8, $21,22]$. Studies were performed with Genesys 5 spectrophotometer (USA). Intensity of lipid peroxidation processes in blood serum and heart, liver and spleen tissues was determined by the level of diene conjugates (DC) and malonic dialdehyde (MDA) by its reaction with thiobarbituric acid using spectrophotometer $[16,17]$. Heart and liver tissues were homogenized with a micro-grinder at a temperature of $4^{\circ} \mathrm{C}$; homogenate was centrifuged at $500 \mathrm{G}$ to settle out the intact cells and tissue fragments. In supernatant, DC and MDA were determined following the above-mentioned procedures; the MDA content was calculated per protein gram. Intensity of free radical processes in blood serum was analyzed by chemiluminescence (CL) method with HLM-003 apparatus, using the following parameters: spontaneous luminosity, characterizing the initial level of free radical oxidation (FRO), fast flare $(h)$ for the concentration of lipid hydroperoxides, and luminescence sum of slow flare $(S)$ to charac- terize maximum possible intensity of LPO induced by $\mathrm{Fe}^{2+}$ ions $[9,10]$. Results were statistically processed using Student t-test and Mann-Whitney $U$-criterion.

Results and discussion. As can be seen from the data (Table 1), that reflect lipoperoxidation processes intensity under $\mathrm{Fe}^{2+}$ cations, DC concentration in serum increased by $18 \%$ and MDA concentration - by $14 \%$ in comparison with the intact group.

The review of CL parameters in blood serum of rats receiving $\mathrm{Cr}^{6+}$ revealed general tendency to increasing intensity of FRO (Table 2 ) at all exposure stages. Thus, it is shown that, comparing to the reference, spontaneous luminosity is slightly reducing by the $45^{\text {th }}$ day of experiment with the subsequent increase on the $90^{\text {th }}$ day. Fast flare, which reflects hydroperoxides content in serum, also decreased by the $45^{\text {th }}$, and increased 6.5 times by the $90^{\text {th }}$ day, compared to the reference. Luminescence sum level, reflecting total antioxidant activity of serum, when consuming $\mathrm{Cr}^{6+}$, was almost 2.5 times higher during two periods of experiment, in relation to the intact animals.

Table 1

$\mathrm{Fe}^{2+}$ cations' effect on intensity of lipid peroxidation processes in rats serum, liver, heart, $M \pm m$

\begin{tabular}{|c|c|c|c|}
\hline Parameter & Reference & $\operatorname{Iron}\left(2^{+}\right)$ & $\begin{array}{c}\text { Statistical } \\
\text { significance }\end{array}$ \\
\hline $\begin{array}{l}\text { MDA, serum, } \\
\text { Mmo/l }\end{array}$ & $\begin{array}{l}181,54 \pm \\
\pm 35,731\end{array}$ & $\begin{array}{l}206,75 \pm \\
\pm 50,512\end{array}$ & $p>0,05$ \\
\hline $\begin{array}{l}\text { MDA, heart, } \\
\text { Mmo/l }\end{array}$ & $\begin{array}{l}0,423 \pm \\
\pm 0,029\end{array}$ & $\begin{array}{l}0,471 \pm \\
\pm 0,058\end{array}$ & $p>0,05$ \\
\hline $\begin{array}{l}\text { MDA, liver, } \\
\text { Mmo/l }\end{array}$ & $\begin{array}{l}0,355 \pm \\
\pm 0,031\end{array}$ & $\begin{array}{l}0,416 \pm \\
\pm 0,048\end{array}$ & $p>0,05$ \\
\hline $\mathrm{DC}$, serum, $\mathrm{Mmo} / 1$ & $\begin{array}{c}456,11 \pm \\
\pm 3,011\end{array}$ & $\begin{array}{l}537,50 \pm \\
\pm 57,590\end{array}$ & $p>0,05$ \\
\hline $\begin{array}{l}\text { DC, heart, } \\
\text { absorbency unit }\end{array}$ & $\begin{array}{l}0,455 \pm \\
\pm 0,037\end{array}$ & $\begin{array}{l}0,472 \pm \\
\pm 0,045\end{array}$ & $p>0,05$ \\
\hline $\begin{array}{l}\text { DC, liver, } \\
\text { absorbency unit }\end{array}$ & $\begin{array}{l}0,475 \pm \\
\pm 0,105\end{array}$ & $\begin{array}{l}0,545 \pm \\
\pm 0,090\end{array}$ & $p>0,05$ \\
\hline $\begin{array}{l}\mathrm{SOD}, \\
\text { relative unit/gHb }\end{array}$ & $\begin{array}{l}257,0 \pm \\
\pm 26,192\end{array}$ & $\begin{array}{c}157,81 \pm \\
\pm 9,031\end{array}$ & $p>0,01$ \\
\hline $\begin{array}{l}\text { Catalase, } \\
\text { relative unit/gHb }\end{array}$ & $\begin{array}{r}200,77 \pm \\
\pm 28,489\end{array}$ & $\begin{array}{r}131,11 \pm \\
\pm 9,202\end{array}$ & $0,01<p<0,05$ \\
\hline
\end{tabular}


Table 2 Effect of chromium on FRO processes intensity in serum of Wistar rats, per exposure dates

\begin{tabular}{|c|c|c|c|}
\hline Group & $\begin{array}{c}\text { Spontaneous } \\
\text { luminosity, } \\
\text { relative units }\end{array}$ & $\begin{array}{c}\text { Rapid flare, } \\
\text { relative units }\end{array}$ & $\begin{array}{c}\text { Luminescence } \\
\text { sum of slow } \\
\text { flare, relative } \\
\text { units }\end{array}$ \\
\hline Reference & $0,33 \pm 0,05$ & $0,75 \pm 0,22$ & $2,01 \pm 0,32$ \\
\hline 45 days & $0,25 \pm 0,03$ & $0,36 \pm 0,02$ & $\mathbf{4 , 6 0} \pm \mathbf{1 , 2 7}$ \\
\hline 90 days & $0,39 \pm 0,10 \mathbf{\Delta}$ & $\mathbf{4 , 8 7} \pm \mathbf{2 , 5 9}$ & $5,10 \pm 2,08$ \\
\hline
\end{tabular}

Note: Indication for statistical significance $(p<$ $0.05)$ : bold print - compared with the reference; $\boldsymbol{\Delta}-45$ and 90 days $(p<0.05)$.

Table 3

$\mathrm{Cr}^{6+}$ effect on DC formation intensity (relative unit/ protein $\mathrm{mg}$ ) and MDA (nmol/ protein $\mathrm{mg}$ ) in spleen and liver of Wistar rats

\begin{tabular}{|c|c|c|c|c|c|}
\hline Group & Day & \multicolumn{2}{|c|}{ Spleen } & \multicolumn{2}{|c|}{ Liver } \\
\hline \multirow[b]{2}{*}{ Reference } & & DC & MDA & DC & MDA \\
\hline & & $\begin{array}{c}0,39 \pm \\
\pm 0,01 \\
(n=28)\end{array}$ & $\begin{array}{c}1,33 \pm \\
\pm 0,09 \\
(n=28)\end{array}$ & $\begin{array}{l}0,40 \pm \\
\pm 0,02 \\
(n=6) \\
\end{array}$ & $\begin{array}{c}3,73 \pm \\
\pm 0,53 \\
(n=32)\end{array}$ \\
\hline \multirow{2}{*}{$\begin{array}{c}\text { Chrome } \\
\text { (VI) }\end{array}$} & 45 & $\begin{array}{c}0,34 \pm \\
\pm 0,01 \\
(n=10)\end{array}$ & $\begin{array}{l}2,26 \pm \\
\pm 0,40 \\
(n=8)\end{array}$ & $\begin{array}{c}\mathbf{0 , 3 6} \pm \\
\pm \mathbf{0 , 0 1} \\
(n=10)\end{array}$ & $\begin{array}{l}\mathbf{8 , 2 8} \pm \\
\pm 1,71 \\
(n=8)\end{array}$ \\
\hline & 90 & $\begin{array}{c}0,47 \pm \\
\pm 0,01 \triangle \\
(n=8)\end{array}$ & $\begin{array}{c}2,03 \pm \\
\pm 0,32 \\
(n=12)\end{array}$ & $\begin{array}{c}\mathbf{0 , 5 7 \pm} \pm \\
\pm \mathbf{0 , 0 1 \Delta} \\
(n=8)\end{array}$ & $\begin{array}{c}3,86 \pm \\
\pm 0,60 \mathbf{\Delta} \\
(n=23)\end{array}$ \\
\hline
\end{tabular}

Note: Indication for statistical significance $(p<$ $0.05)$ : bold print - compared with the reference; $\boldsymbol{\Delta}-45$ and 90 days $(p<0.05)$.

Studying the dynamics of DC and MDA formation in rats' spleen and liver (Table 3) revealed general direction to increase in their concentration, as in the case with $\mathrm{Fe}^{2+}$ intake.

Thus, it was found that, comparing to the reference group, the chromium-consuming rats showed an increase in DC concentration by 1.2 times on the $90^{\text {th }}$ day of the experiment, while MDA level did not change authentically.

In comparison with the reference group, in liver of rats receiving $\mathrm{Cr}^{6+}$, there was a 1.1 time decrease in DC concentration on the $45^{\text {th }}$ day and, on the contrary, 1.4 times increase on the $90^{\text {th }}$ day of the experiment. MDA content in liver increased with the maximum of 45 days: 2.2 times.

Studying the antioxidant enzymes in rats treated with $\mathrm{Cr}^{6+}$, compared with the reference group $(257.40 \pm 8.49$ rel.unit $/ \mathrm{gHb})$, revealed a decrease in catalase activity on the $45^{\text {th }}$ day (218.68 \pm 3.75 rel. units/gHb), while SOD activity decreased on the $90^{\text {th }}$ day of exposure (123.39 \pm 14.24 rel.units/gHb) comparing to the reference group (226.68 \pm 25.58 rel.units/gHb ).

Thus, experimental results showed that $\mathrm{Fe}^{2+}$ intake with drinking water in a concentration corresponding to 0.5 MPC can cause moderate activation of free-radical oxidation. This metal in biological medium is a key element in generation of active particles, including superoxide-anion-radical and the most reactive hydroxyl radical formed mainly at hydrogen peroxide decomposition [13-15, 18]. Implementation of the given mechanism is accompanied with a decreasing activity of SOD antioxidant enzymes and catalase, which was proved by the performed research.

Study of the possible effect from another redox-active metal $\mathrm{Cr}^{6+}$ at a concentration equal to $1 \mathrm{MPC}$ on the intensity of free-radical processes in blood serum also showed their enhancement, progressing with the increasing duration of exposure. The activation of processes by chromium cations action is due to its direct effect on free-radical mechanisms. In biological medium, $\mathrm{Cr}^{6+}$ ions are reduced to $\mathrm{Cr}^{3+}$ mainly by the action of glutathione and vitamin $C[5,6,19]$. The one-electron reduction process with intermediates generation in medium oxidation states is associated with the formation of reactive oxygen intermediate, which results in enhancement of free-radical processes, probably due to interaction of $\mathrm{Cr}^{\mathrm{n}+}$ $(6 \leq n \leq 3)$ with hydrogen peroxide, according to Haber-Weiss and Fenton reactions. Inactivation effect of SOD enzymes and catalase shown by the study results also causes a pronounced activation of free-radical oxidation processes and oxidative stress.

Generally, effects of isolated exposure to iron and chromium ions shown in this study testified that, under multi-component envi- 
ronmental factors, it is necessary to take into account not so much their concentrations with reference to the maximum permissible ones, as primarily the possibility to realize their pres- ence in body through various mechanisms, giving also attention to an expectable potentiating action in cases of simultaneous intake.

\section{References}

1. Boev V.M. Mikroelementy i dokazatel'naya meditsina [Trace elements and evidence-based medicine]. Moscow, Meditsina Publ., 2005, 208 p. (in Russian).

2. Vladimirov Yu.A. Svobodnye radikaly v biologicheskikh sistemakh [Free radicals in biological systems]. Sorosovskii obrazovatel'nyi zhurnal, 2000, vol.6, no. 12, pp. 13-19 (in Russian).

3. Vladimirov Yu.A., Archakov A.I. Peroksidnoe okislenie lipidov v biologicheskikh membranakh [Lipid peroxidation in biological membranes]. Moscow, Nauka, 1972, 252 p. (in Russian).

4. Chesnokova L.A., Mikhailova I.V., Krasikov S.I., Lebedeva E.N., Voronkova I.P., Karmanova D.S. Vliyanie pestitsidov i kationov zheleza na pokazateli immunnoi sistemy i lipoperoksidatsiyu krys Vistar [Effects of pesticides and iron cations on immune system parameters and lipid peroxidation in Wistar rats]. Intellekt. Innovatsii. Investitsii, 2013, no.1, pp.152-155 (in Russian).

5. Isidorov V.A. Vvedenie $\mathrm{v}$ khimicheskuyu ekotoksikologiyu [Introduction to chemical ecotoxicology]. St. Petersburg, Khimizdat Publ., 1999, 144 p.

6. Men'shchikova E.B., Lankin V.Z., Zenkov N.K. [et al.]. Okislitel'nyi stress. Prooksidanty i antioksidanty [Oxidative stress. Pro-oxidants and antintioxidants]. Moscow, Slovo Publ., 2006, 556 p. (in Russian).

7. Mikhailova I.V. Vliyanie khroma i benzola na immunnuyu sistemu i uroven' mikroelementov v biosredakh krys Vistar [Effect of chromium and benzene on the immune system and the level of trace elements in Wistar rats bioenvironments]. Informatsionnyi arkhiv, 2010, vol. 4, no. 3-4, pp. 85-88 (in Russian).

8. Sirota T.V. Novyi podkhod $\mathrm{v}$ issledovanii protsessa autookisleniya adrenalina i ispol'zovanie ego dlya izmereniya aktivnosti superoksiddismutazy [A new approach to the investigation of adrenaline autooxidation and its application for determination of superoxide dismutase activity]. Voprosy meditsinskoi khimii, 1999, vol. 45, no. 3, pp. 263-272 (in Russian).

9. Skal'nyi A.V., Esenin A.V. Monitoring i otsenka riska vozdeistviya svintsa na cheloveka i okruzhayushchuyu sredu s ispol'zovaniem biosubstratov cheloveka [Monitoring and assessing risks of impacts exerted by $\mathrm{Pb}$ on a man and environment with the use of human biological host materials]. Toksikologicheskii vestnik, 1997, no. 6, pp. 15-22 (in Russian).

10. Fakhrutdinov R.R. Svobodnoradikal'noe okislenie $\mathrm{v}$ biologicheskom materiale i khemilyuminestsentnye metody issledovaniya $\mathrm{v}$ eksperimental'noi i klinicheskoi meditsine [Free radical oxidation in biological material and chemiluminescent methods in experimental research and clinical medicine]. Ufa, 2002, pp. 102-104 (in Russian).

11. Rakhmanin Yu.A., Boev V.M., Aver'yanov V.N., Dunaev V.N. Khimicheskie i fizicheskie faktory urbanizirovannoi sredy obitaniya [The chemical and physical factors of the urban environment]. Orenburg, Yuzhnyi Ural Publ., 2004, 432 p. (in Russian).

12. Khudolei V.V., Mizgirev I.V. Ekologicheski opasnye factory [Ecologically hazardous factors]. St. Petersburg, Publishing House Publ., 1996, 111 p. (in Russian).

13. Yudina T.V., Gil'denskiol'd R.S., Egorova M.V. Opredelenie tyazhelykh metallov v volosakh [Determination of heavy metals in hair]. Gigiena i sanitariya, 1988, no.2, pp. 50-52 (in Russian).

14. Andrews N.C. Disorders of Iron Metabolism. New England Journal of medicine, 1999, vol. 341, no. 26, pp. 1986-1995.

15. Baker W.F.Jr. Iron deficiency in pregnancy, obstetrics, and gynecology. Hematol. Oncol. Clin. North. Am., 2000, vol.14, no. 5, pp. 1061-1077.

16. Liochev S.J., Fridovich I. The Haber-Weiss cycle -70 years later: an alternative view. Redox Rep, 2002, vol.7, pp. 55-57. 
17. Ohkawa H., Ohishi N., Vagi K. Assay for lipid peroxides in animal tissues by thiobarbituric acid reaction. Analyt. Biochem, 1979, vol.95, no. 2, pp. 351-358.

18. Placer Z. Lip. Peroxidation sisteme in biologischen material. Nahrung, 1968, vol. 12, pp. 679.

19. Prousek J. Fenton chemistry in biology and medicine. Pure Appl. Chem, 2007, pp. 2325-2338.

20. Standeven A.M., Wetterhahn K.E. Ascorbate is the principal reductant of chromium(VI) in rat lung ultrafiltrates and cytosols, and mediates chromium-DNA binding in vitro. Carcinogenesis, 1992, vol. 13, pp. 1319-1324.

21. Valko M., Morris H., M.T.D. Cronin. Metals, toxicity, oxidative stress. Current Medicinal chemistry, 2005, vol. 12, no.10, pp. 1177-1180.

22. Zuck H. Methods of enzymatic analysis. Ed by Bergmeger H., Pergamon Press, 1963, pp. 885894.

Chesnokova L.A, Mikhailova I.V., Krasikov S.I., Boev V.M. Influence exerted by redox-active metals on oxidative stress evidence in an experiment. Health Risk Analysis, 2017, no. 2, pp. 125-129. DOI: 10.21668/health.risk/2017.2.15.eng

Received: 22.01 .2017

Accepted: 28.02.2017

Published: 30.06 .2017 
